\title{
Elemental and structural changes in illite/smectite mixed-layer clay minerals during diagenesis in Kimmeridgian- Volgian (- Ryazanian) clays in the Central Trough, North Sea and the Norwegian- Danish Basin
}

\author{
Holger Lindgreen
}

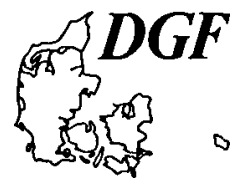

Lindgreen, H.: Elemental and structural changes in illite/smectite mixed-layer clay minerals during diagenesis in Kimmeridgian- Volgian (- Ryazanian) clays in the Central Trough, North Sea and the Norwegian- Danish Basin. Bull. geol. Soc. Denmark, Vol. 39, pp. 1-82, Copenhagen, October 25th, 1991. https://doi.org/10.3 $3^{7} 5^{7} 0 /$ bgsd-1991-39-01

The literature on the diagenetic conversion of smectite layers to illite layers in mixed-layer illite/smectite is reviewed. According to this smectite layers are converted to illite layers during diagenesis at temperatures above $55^{\circ} \mathrm{C}$ and illite/smectites become IS ordered at about $100^{\circ} \mathrm{C}$ and at illite percentages of about $80 \%$. Charge and elemental composition seem, beside temperature, to be of importance in the process. Investigations from metamorphic and hydrothermal areas have also found a conversion of smectite to illite layers with increasing temperature. In hydrothermal experiments, the process has been found to occur at temperatures of $250^{\circ} \mathrm{C}$ and above. Investigations from metamorphic areas have shown that the increase in amount of illite layers in illite/smectite during short lived heating events is very slow compared to the increase in vitrinite reflectancy. The elemental changes during illite layer formation are a substitution of $\mathrm{Al}^{3+}$ for $\mathrm{Si}^{4+}$ in the tetrahedral sheet and a fixation of $\mathrm{K}^{+}$between $2: 1$ units. Some investigations have also found substitution of $\mathrm{Al}^{3+}$ for $\mathrm{Mg}^{2+}$ and $\mathrm{Fe}$ and a reduction of $\mathrm{Fe}^{3+}$ in the octahedral sheet. The changes seen during the hydrothermal experiments and in hydrothermal areas are different from the diagenetic changes in that higher negative charges are created and $\mathrm{Na}^{+}$ and $\mathrm{Ca}^{2+}$ are fixed under hydrothermal conditions. Two models have been proposed for the diagenetic formation of illite layers from smectite layers: 1) A solid-state $\mathrm{Al}^{3+}$ for $\mathrm{Si}^{4+}$ substitution in the tetrahedral sheets of smectite layers and sub-sequent fixation of $\mathrm{K}^{+}$and interlayer collapse, giving illite layers; and 2) A dissolution of smectite layers and crystallization and growth of illite crystals. $\mathrm{K}^{+}$ supply is the main control on the formation of illite layers from smectite. Even in systems with sufficient $\mathrm{K}^{+}$available, other cations such as $\mathrm{Mg}^{2+}, \mathrm{Ca}^{2+}$, and $\mathrm{Na}^{+}$may inhibit $\mathrm{K}^{+}$- fixation and illite layer formation.

The release of clay transformation water and its possible role in petroleum migration has been the subject of several investigations. There seems in most cases to be a coincidence between collapse of interlayer space (assumed to release interlayer water) and the generation of petroleum. But the role of the water released during clay diagenesis is not clear.

The geology of the Central Trough and the Norwegian-Danish Basin is shortly reviewed. The source of the Upper Jurassic clays was probably mainly the Fennoscandian Shield. In addition volcanic material including ash has probably been sedimented in the North Sea region during Upper Jurassic.

Cores and hand-picked cuttings samples from the Mandal, Farsund and Haugesund Formations in the Central Trough and from the Sauda, Tau, Børglum and Bream Formations in the Norwegian-Danish Basin have been investigated. Intact bulk rock samples were ion-milled and investigated by high resolution transmission electron microscopy (HRTEM). The samples were also ultrasonically and chemically treated and the mixed-layer illite/smectite isolated by centrifuging. The illite/smectite samples thus obtained were investigated by HRTEM, by transmission electron microscopy (TEM) on shadowed specimens, by X-Ray diffraction (XRD), by ${ }^{27} \mathrm{Al}$ and ${ }^{29} \mathrm{Si}$ magic angle spinning, nucleár-magnetic resonance spectroscopy (mas-nmr), by infrared spectroscopy (IR), and by chemical analysis for elements and $\mathrm{NH}_{4}{ }^{+}$. Illite percentages and ordering in illite/smectite were estimated by computer simulation of XRD patterns by the NEWMOD program for two-component systems and by a program for three component systems. The interpretations of the HRTEM images of illite/smectite structures in intact bulk rock were supported by computer simulations.

The results of XRD on coarse clay fractions indicated that the main source area for the Upper Jurassic claystones was the Fennoscandian Shield.

XRD supported by computer simulations showed that the amount of illite layers in illite/smectite was between $40 \%$ and $80 \%$ illite layers in randomly ordered or I-S segregated illite/smectite, between $80 \%$ and $90 \%$ in mainly IS ordered illite/smectite, and about $95 \%$ illite layers in ISII ordered illite/smectite. 
10-14 $\AA$ distances were seen in lattice fringes by HRTEM on intact bulk rock and are probably due to smectite layers with non-contracted interlayer space, whereas $10 \AA$ lattice fringes can be due to illite or collapsed smectite and $14 \AA$ distances to chlorite or non-collapsed smectite. $10 \AA$ lattice fringes with periodically enhanced contrast were observed by HRTEM on intact bulk rock in all Central Trough samples investigated. Regular $20 \AA$ period sequences of such enhanced contrast were most frequent but also $30 \AA$ period sequences and sequences with enhanced contrast occurring randomly along $c^{*}$ were seen. These particles are MacEwan illite/smectite particles. The specimens prepared for HRTEM from dispersed illite/smectite contained a large amount of thin particles with $10 \AA$ period in contrast but also, in IS ordered illite/smectite, a large number of particles with $20 \AA$ periodically enhanced contrast, MacEwan particles. It is concluded that the thin particles seen by HRTEM and TEM on specimens prepared from dispersed illite/smectite have probably formed by dispersion of the thick particles seen by HRTEM in intact bulk rock.

The illite/smectite from the Norwegian-Danish Basin, with $65-75 \%$ illite layers and randomly ordered or I-S segregated, is probably detrital. Similar illite/smectite at shallow depth (less than about $\mathbf{3 ~ k m}$ ) and low temperatures (less than about $100^{\circ} \mathrm{C}$ ) in the Central Trough is probably also detrital, but at larger depths and higher temperatures it is diagenetically changed to predominantly IS ordered illite/smectite with $80-95 \%$ illite layers. This change occurs at a vitrinite reflectancy of about $0.65 \%$, i.e. at about oil generation.

Chemical analysis and mas-nmr showed that the formation of illite layers is accompanied by an increase in tetrahedral $\mathrm{Al}$ and a minor increase in octahedral $\mathrm{Al}$, by a decrease in tetrahedral $\mathrm{Si}$ and by a minor decrease in octahedral $\mathrm{Mg}$ and $\mathrm{Fe}$. Analysis of pore water from Upper Jurassic claystone cores gave ratios for $\mathrm{K}^{+} / \mathrm{NH}_{4}{ }^{+}$in pore water similar to those in illite/smectite from the same depth, indicating that the relative amounts of $\mathrm{K}^{+}$and $\mathrm{NH}_{4}{ }^{+}$control the fixation of these cations in illite/smectite.

The ordering of illite and smectite layers in MacEwan particles in intact bulk rock, observed in images as $20 \AA$ (and sometimes $30 \AA$ ) periods of enhanced contrast, can only have formed during solid-state smectite to illite formation, the polarization effect probably being responsible. The chemical analyses show that the illite layers have charges of about -0.8 , less than the ideal -1.0 of mica. Such low charge illite layers can form during a solid-state transformation. It is concluded that the formation of illite layers from smectite layers in the Upper Jurassic claystones is a solid-state transformation.

Holger Lindgreen, Geological Survey of Denmark, Thoravej 8, DK-2400, Copenhagen NV. August 20 th, 1991 .

\section{Introduction}

The key to the development in clay mineralogy has been the development of analytical equipment in this century. X-ray diffraction supported by computer simulation furnishes information on clay mineral groups present in samples and on the presence of mixed-layer clays and the statistics of mixing. This is essential in investigation of mixedlayer illite/smectite diagenesis. High resolution transmission electron microscopy and electron diffraction can give information on the layering and layer types present in intact bulk rock. Chemical analyses of mixed-layer clays furnish their elemental composition. ${ }^{27} \mathrm{Al}$ and ${ }^{29} \mathrm{Si}$ nuclear magnetic resonance magic- angle spinning spectroscopy and ${ }^{57} \mathrm{Fe}$ Mössbauer spectroscopy give information on the coordination of $\mathrm{Al}, \mathrm{Si}$, and $\mathrm{Fe}$ and on the valency of $\mathrm{Fe}$, information which is essential in investigations on diagenesis, as an important diagenetic process is $\mathrm{Al}$ for $\mathrm{Si}$ substitution in the clay mineral layers. In addition, infrared spectroscopy can supply information on the types of bonds between elements present in the sample. An up-to date investigation of diagenesis of clay minerals is therefore dependant on the availability of these techniques.
The exploration for oil and gas in the Danish area was initiated late in the 1930's and drilling continued onshore after the Second World War. Several wells were drilled but only traces of oil and gas have been found onshore. In the Central Trough of the North Sea, drilling discovered several oil and gas reservoirs. Oil and gas are formed in source rocks and migrate out of these rocks to the reservoirs. An important part of the evaluation of the oil and gas potential is therefore an investigation of the source rock potential. This is determined by the amount of source rock present, its content and type of organic material, and its degree of maturity. Combined organochemical, coal petrographical and clay mineralogical investigations of the source rock potential in the Danish concession area were carried out in the Source Rock Project, which started in April 1981 and was funded by the Danish Energy Research Council. Organochemistry and coal petrography are well established methodologies in source rock evaluations. The publications of Hower and coworkers on the clay mineralogy of the U.S. Gulf Coast Tertiary shales, of Foscolos and co-workers on Canadian Tertiary to Jurassic shales, of Heling and Teichmüller on the Tertiary shales of the Rhine Graben, and of Środon on the Silesian 


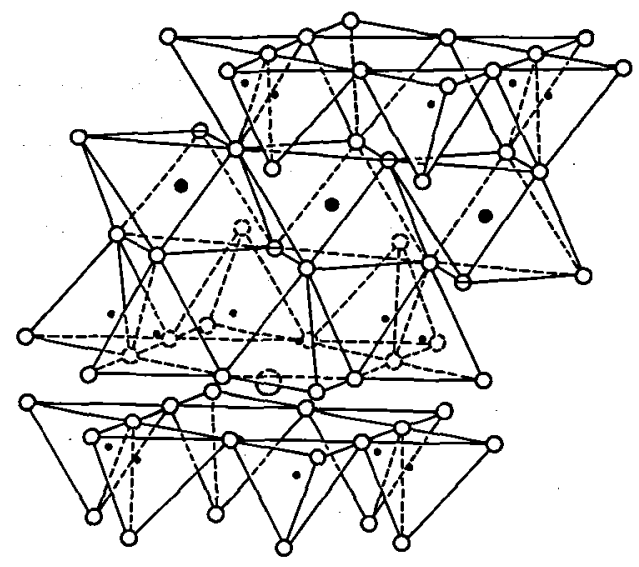

$\begin{array}{ll}\text { O: Oxygen } & \because \text { tetrahedral cation } \\ \Theta: \text { hydroxyl } & \because \text { : octahedral cation or } \\ \text { vacancy }\end{array}$

Fig. 1. Simplified model for mica. Modified from Goodman (1976, fig. 2). Originally from Grim (1953, fig. 14).

of Poland have shown that the percentage of illite layers and the degree of ordering in mixed-layer illite/smectite increase during diagenesis. Coal petrography and organochemistry showed that the main source rocks in the Danish area are of Upper Jurassic age and that they are mature in large parts of the Central Trough and pre-mature in the Danish Subbasin. The X-ray diffractograms of clay fractions $(<2 \mu \mathrm{m})$ from these rocks were dominated by discrete illite and kaolinite and investigation of mixed-layer illite/smectite was therefore difficult. The mineralogical part of the source rock evaluations of Upper Jurassic rocks dealt therefore mainly with correlations between non-clay mineralogy and maturity of the organic matter.

This left the question of clay mineralogical changes during diagenesis in the Upper Jurassic source rocks unanswered. Late in the project, X-ray diffraction, Mössbauer spectroscopy and chemical elemental investigations on fine-clay fractions $(<0.2 \mu \mathrm{m})$ from these rocks showed that ordering of the mixed-layer illite/smectite was roughly coincident with oil generation. The opportunity came to investigate in detail the structural changes of the mixed layers during diagenesis when I obtained a senior scholarship at the Institute of Mineralogy, University of Copenhagen. I carried out X-ray diffraction at the Institute of Mineralogy, chemical elemental deter- minations at the Department of Chemistry and the Department of Physics at the Royal Veterinary and Agricultural University, infrared spectroscopy at the H.C.Ørsted Institute, and Mössbauer spectroscopy at the Geological Survey of Denmark. Programs for computersimulation of diffractograms of two-component mixtures were kindly placed at my disposal by R.C.Reynolds and for three-component mixtures by P.D.Cradwick. These investigations were combined with results of solid-state ${ }^{27} \mathrm{Al}$ and ${ }^{29} \mathrm{Si}$ NMR carried out at the Department of Chemistry, University of Aarhus by lektor Hans Jørgen Jakobsen and cand. scient. Hans Jacobsen, and with results from high resolution transmission electron microscopy and diffraction carried out at the Laboratory of Applied Physics, Technical University of Denmark, by cand. scient. Poul Lenvig Hansen. Professor Harry Micheelsen investigated the coarse fractions $(>10 \mu \mathrm{m})$ of the rocks by light microscopy and spent several months to make the three component program of P.D.Cradwick operative on a computer at the Institute of Mineralogy.

\section{The structure of clay minerals}

\section{Terminology}

The clay crystal terminology adopted by AIPEA (Bailey 1980) will be used in the following. Thus, the term "structure" means a physical arrangement of atoms or ions, "plane" means a single plane of atoms in a structure, "sheet" is used as in an octahedral or a tetrahedral sheet, and "layer" is used as in a 1:1 layer or a 2:1 layer. The terms "plane", "sheet" and "layer" refer to increasingly thicker arrangements; a sheet is a combination of planes, and a layer is a combination of sheets. In addition, layers may be separated from one another by "interlayer" material, such as cations.

\section{The structure of clay mineral layers}

A simplified mica model is shown in fig. 1. Clay minerals are sheet silicates composed of tetrahedral and octahedral sheets. The tetrahedral sheets are built up with a central cation, mainly $\mathrm{Si}^{4+}$, with four oxygen anions at the apices. The formula for the tetrahedral sheet alone is thus, 
Table 1. Classification scheme for phyllosilicates related to clay minerals, Bailey (1980, p.74).

\begin{tabular}{|c|c|c|c|}
\hline $\begin{array}{l}\text { Layer } \\
\text { type }\end{array}$ & $\begin{array}{l}\text { Group } \\
(x=\text { charge per formula unit })\end{array}$ & Subgroup & Species ${ }^{1}$ \\
\hline $1: 1$ & $\begin{array}{l}\text { Kaonite-serpentine } \\
x^{-} 0\end{array}$ & $\begin{array}{l}\text { Kaonite } \\
\text { Serpentine }\end{array}$ & $\begin{array}{l}\text { Kaonite, dickite, halloysite } \\
\text { Chrysotile, lizardite, amesite }\end{array}$ \\
\hline \multirow{6}{*}{$2: 1$} & $\begin{array}{l}\text { Kaolinite-serpentine } \\
x^{-} 0\end{array}$ & $\begin{array}{l}\text { Pyrophyllite } \\
\text { Talc }\end{array}$ & $\begin{array}{l}\text { Pyrophyllite } \\
\text { Talc }\end{array}$ \\
\hline & $\begin{array}{l}\text { Smectite } \\
x^{-} 0,2-0.6\end{array}$ & $\begin{array}{l}\text { Dioctahedral smectite } \\
\text { Trioctahedral smectite }\end{array}$ & $\begin{array}{l}\text { Montmorillonite, beidellite } \\
\text { Saponite, hectorite, sauconite }\end{array}$ \\
\hline & $\begin{array}{l}\text { Vermiculite } \\
x^{-} 0.6-0.9\end{array}$ & $\begin{array}{l}\text { Dioctahedral vermiculite } \\
\text { Trioctahedral vermiculite }\end{array}$ & $\begin{array}{l}\text { Dioctahedral vermiculite } \\
\text { Trioctahedral vermiculite }\end{array}$ \\
\hline & $\begin{array}{l}\mathrm{Mica}^{2} \\
\mathrm{x}^{-} 1\end{array}$ & $\begin{array}{l}\text { Dioctahedral mica } \\
\text { Trioctahedral mica }\end{array}$ & $\begin{array}{l}\text { Muscovite, paragonite } \\
\text { Phlogopite, biotite, lepidolite }\end{array}$ \\
\hline & $\begin{array}{l}\text { Brittle mica } \\
x^{-} 2\end{array}$ & $\begin{array}{l}\text { Dioctahedral brittle mica } \\
\text { Trioctahedral brittle mica }\end{array}$ & $\begin{array}{l}\text { Margarite } \\
\text { Clintonite, anandite }\end{array}$ \\
\hline & $\begin{array}{l}\text { Clorite } \\
\times \text { variable }\end{array}$ & $\begin{array}{l}\text { Dioctahedral chlorite } \\
\text { Di,trioctahedral chlorite } \\
\text { Trioctahedral chlorite }\end{array}$ & $\begin{array}{l}\text { Donbassite } \\
\text { Cookeite, sudoite } \\
\text { Clinochlore, chamosite, nimite }\end{array}$ \\
\hline
\end{tabular}

1 Only a few examples are given

${ }^{2}$ The status of illite (or hydromica), sericite, etc. must be left open at present, because it is not clear whether or at what level they should enter the table; many materials so designated may be interstratified.

with one hydroxyl group available at each tetrahedron for bonding to the octahedral sheet: $\mathrm{Si}_{2} \mathrm{O}_{3}$ $(\mathrm{OH})_{2}$. The octahedral sheets are built up with a central cation, usually $\mathrm{Al}^{3+}, \mathrm{Fe}^{3+}, \mathrm{Fe}^{2+}$ or $\mathrm{Mg}^{2+}$, with 6 anions at the apixes. With $\mathrm{Al}^{3+}$ as the cation the formula for the octahedral sheet can be written: $\mathrm{Al}_{2}(\mathrm{OH})_{6}$. Bonding of one octahedral sheet to one tetrahedral sheet as in the 1:1 or 2-layer silicates results in the formula: $\mathrm{Al}_{2} \mathrm{Si}_{2} \mathrm{O}_{5}$ $(\mathrm{OH})_{4}$, and bonding of two tetrahedral sheets to one octahedral sheet as in the 2:1 or 3-layer silicates results in the formula: $\mathrm{Al}_{2} \mathrm{Si}_{4} \mathrm{O}_{10}(\mathrm{OH})_{2}$. Only $2 / 3$ of the octahedral vacancies are filled in sheets with trivalent cations, dioctahedral sheets, whereas octahedral sheets of divalent cations like $\mathrm{Mg}^{2+}$ or $\mathrm{Fe}^{2+}$, trioctahedral sheets, have all vacancies filled and the corresponding formulae are: for 1:1 or 2-layer silicates: $\mathrm{Mg}_{3} \mathrm{Si}_{2} \mathrm{O}_{5}(\mathrm{OH})_{4}$ and for 2:1 or 3 layer silicates: $\mathrm{Mg}_{3} \mathrm{Si}_{4} \mathrm{O}_{10}(\mathrm{OH})_{2}$. So far the layers have no charge. The 2:1 layers obtain a permanent, negative charge, if $\mathrm{Si}^{4+}$ in the tetrahedral sheet is substituted by $\mathrm{Al}^{3+}$ or $\mathrm{Fe}^{3+}$ and/or if an octahedral $\mathrm{Al}^{3+}$ or $\mathrm{Fe}^{3+}$ in the octahedral sheet is substituted by $\mathrm{Mg}^{2+}$ or $\mathrm{Fe}^{2+}$. This negative charge is balanced by cations clustering around or fixed at the surface of the layers. Substitution degrees are low in 1:1 layer silicates and also in 2:1 layer silicates with interlayered octahedral sheets (the chlorites) or with alternat- ing 2:1 layers (sepiolites and palygorskites). The degree of substitution is the basis for the classification into groups within the remaining 2:1 layer silicates (talc pyrophyllites, smectites, vermiculites, micas and brittle micas); see table 1 . The classification of the sheet silicates into subgroups is based on whether the octahedral sheet is di- or trioctahedral.

It is noteable that the status of illite is left open in the classification of the International Mineralogical Association shown in table 1 and that many of the materials so designated may be interstratified according to the footnote in table 1. Illite was proposed as a general term for micalike clay minerals by Grim, Bray \& Bradley (1937). Grim (1953) concluded that by then the term illite had been widely accepted for a micatype clay mineral with a $10 \AA \mathrm{c}$-axis spacing and which shows substantially no expanding lattice characteristics. He furthermore proposed a classification of clay minerals according to which three layer types with non-expanding lattice belong to the illite group. It should be noted that the group level in Grim's classification for threelayer silicates is based on expandability. However, the Clay Minerals Society's Nomenclature Committee concluded (Brindley 1966) that a classification of clay minerals cannot be independant of a classification of layer silicates (phyllosili- 
cates). Therefore the classification scheme later adopted (shown in table 1) omitted some commonly used clay mineral terms because their nature was considered to be such that they do not fall within this classification scheme. Bailey (1984) wrote that illite is predominantly dioctahedral but differs from ideal muscovite in having on the average more silicon, magnesium, and water but less interlayer potassium. Bailey noted that although many clays termed illite in the literature are known to contain expandable layers in addition to micaceous layers illite should be used to designate only non-expandable $10 \AA$ mica. This designation will be followed in the present work.

\section{Mixed-layer clay minerals}

In mixed-layer or interstratified clay minerals two or more different layers are interstratified in a more or less random or in a regular way. In this chapter I will denote illite layers and S smectite layers. In later chapters reviewing the literature $\mathrm{M}$ can also be used for montmorillonite layers by the cited authors. Montmorillonite was earlier used as a group name, but was later substituted by the term smectite and montmorillonite was thereafter only smectites with negative layer charges from octahedral substitutions, see table 1. In mixed-layer or interstratified minerals two or more different layers are interstratified in a more or less random or in a regular way. Ideally IS ordered illite/smectite with $50 \%$ illite layers have alternating layers of illite and smectite giving a superlattice of $I+S$ along $c^{*}$. Ideally ISI and ISII ordered illite/smectite consist of I $+\mathrm{S}+$ I and I $+\mathrm{S}+\mathrm{I}+\mathrm{I}$ superlattices, respectively. In order to describe less ideally ordered illite/smectite also, Reynolds (1984) has given a statistical treatment of sequences with two types of layers. He used statistical parameters to describe the sequences of layers in interstratified crystallites. One parameter is the probability of finding one of the components in the layer sequence of principal infinite thickness along $\mathrm{c}^{*}$. The other parameters are junction probabilities giving the probabilities of a layer following another layer (e.g. $P_{A . B}$ ) or following a sequence of specified layers (e.g. $\mathbf{P}_{\mathrm{AA} . \mathrm{B}}$ or $\mathbf{P}_{\mathrm{AAA} . \mathrm{B}}$ ). Ordering implies accordingly that the minor of the two components is always found as a component of the superlattice structure. For example, in IS ordered illite/smectite with more than $50 \%$ illite layers all smectite layers are found in IS units and the remaining illite layers are then distributed among these units. Consequently it is characteristic for IS ordered illite/smectite with more than $50 \%$ illite layers that a smectite layer can never follow a smectite layer in the sequence and for ISI ordered illite/smectite with predominantly illite layers that each smectite layer is separated by at least two illite layers.

The XRD patterns of mixed-layer clay minerals have basal reflections from one or both components together with scatter interference maxima ("compromise diffractions" (Brindley 1981)) between basal reflections from each of the two components, when these reflections occur close to each other (Brindley 1981). As soon as these characteristics were known, mixed-layer clay minerals were observed in many different geological materials. In randomly ordered or I-S segregated mixed-layers dominated by one of the components, the XRD pattern is dominated by the (001) reflections from that component and mixedlayering can therefore only be identified by comparing intensities in the experimental pattern and intensities in computer modelled patterns (see below). Thus, identification of discrete minerals based on the presence of the (001) reflections of these minerals may be erroneous. For example, the presence of discrete smectite cannot be deduced from the presence of a $17 \AA$ peak in glycolated specimens, as done by Heling $(1978,1979)$, because randomly ordered or I-S segregated illite/smectite with up to $70 \%$ illite layers give such a peak (Reynolds 1984). Higher order reflections from ordered mixed-layer minerals may be mistaken for first order reflections of single clay minerals. Thus, a $14 \AA$ peak in glycolated specimens may be due to a vermiculite component, as proposed by Foscolos, Powell \& Gunther (1976), but may also be a (002) from a regularly interstratified illite/smectite. These interpretation difficulties may result in different results from different investigators, see later. Computer modelling of XRD patterns from mixed layer clays with two components was carried out by MacEwan (1956, 1958) for randomly ordered mixed-layers and by Reynolds \& Hower (1970) both for randomly ordered and I-S segregated and for ordered twocomponent mixed-layers. Computer modelling 
Randomly

IS

$|S|$

ordered

ordered

ordered
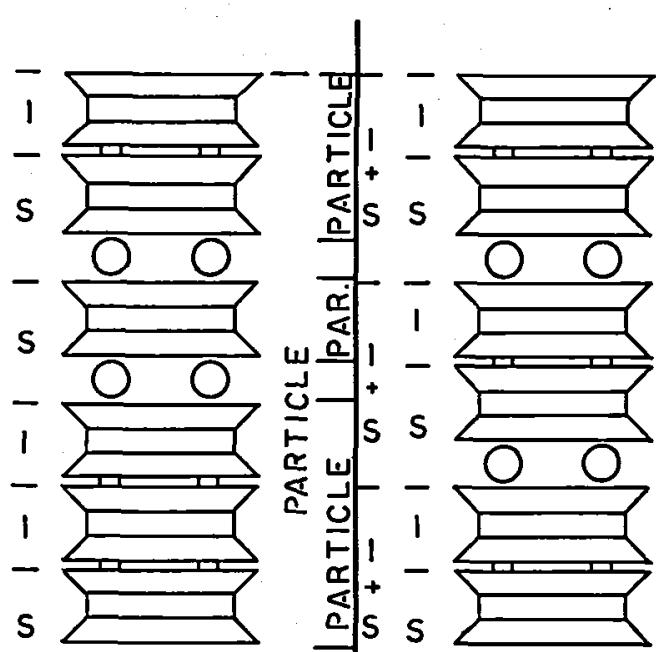

$-1-$

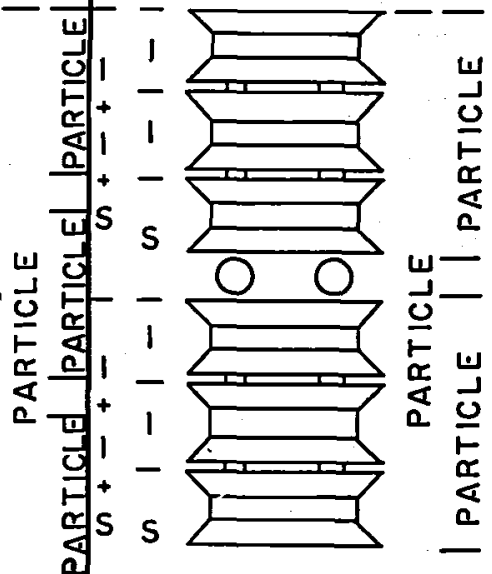

$\bar{n}$
o
$\frac{0}{c}$
$\dot{c}$
$c$
c
$\frac{r}{x}$
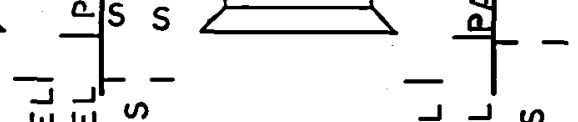

w

○ी

욜 인

$z w \stackrel{\square}{a}$

$\sum_{0} \frac{1}{0} \frac{0}{x}$

름

产遂

$<c$

$\Sigma$

$\dot{1}$

$\stackrel{\leftarrow}{\llcorner}$

$\sum_{5}$

$\sum$

京

u.

\section{—: TETRAHEDRAL SHEET \\ $\square$ : OCTAHEDRAL SHEET}

\section{口: FIXED INTERLAYER CATION}

\section{O: ADSORBED AND EVENTUALLY HYDRATED INTERLAYER CATION}

$S$ : SMECTITE

\section{1 : ILLITE}

Fig. 2. Markovian and fundamental particle models in illite/smectite.

for three-component illite/vermiculite/smectite was done by Cradwick \& Wilson (1978).

The mixed-layering in these calculations was assumed to occur as layers of one component interstratified with layers of the other component (or components) in the same particle, the Marko- vian model (see fig. 2), and particle thicknesses of 5-15 elementary layers produced satisfactory computer simulated patterns. However, TEM on dispersed sodiumsaturated smectites showed that the particles in these specimens were 1-2 elementary layers thick (Mering \& Oberlin 1971). 
Similarly, Weir, Nixon \& Woods (1960) found by TEM on specimens prepared from dispersed allevardite that the dispersion had produced suspended flakes two 2:1 unit layers thick. Nadeau, Tait, McHardy \& Wilson (1984) showed that interparticle diffraction in very thin illite particles (one to more than five unit layers thick) in oriented XRD specimens gives rise to mixed-layer illite/smectite XRD patterns which resemble those modelled with a mean particle thickness in the range 5-15 unit layers. Nadeau et al. (1984) viewed mixed-layer illite/smectite to be composed of elementary illite layers (random distribution in thicknesses: randomly ordered illite/ smectite) and regularity to arise from uniformity in thicknesses of the elementary particles (see fig. 2) (one unit layer: smectite; two unit layers: IS ordered illite/smectite; three unit layers: IIS ordered illite/smectite; four unit layers: IIIS ordered illite/smectite). The smectite spacing of 17 $\AA$ after this model is due to one interparticle spacing of $7 \AA$ plus one illite layer of $10 \AA$ (fig. 2). It should be noted that the interparticle diffraction model has so far only been applied to diagenetic illites from sandstone reservoirs or originating from bentonites. Both the Markovian model and the interparticle diffraction model are based on investigations on dispersed clay specimens. These specimens were saturated with specific cations and/or with ethylene glycol or glycerol so that the $d(001)$ could be correlated to layer charge; this is the criterion for distinguishing between the 2:1 layer clay minerals (table 1). Ahn \& Peacor (1986a) investigated by high resolution transmission electron microscopy (HRTEM) ionmilled rock specimens from Gulf Coast Tertiary well sections. These same samples had been investigated by XRD by Reynolds \& Hower (1970). Ahn \& Peacor found mainly $10 \AA$ thick lattice fringes in 2:1 layer minerals and concluded that the smectite layers had collapsed to $10 \AA$ during specimen preparation and in the vacuum of the microscope and that illite and smectite layers therefore not could be distinguished from their d(001). Ahn \& Peacor observed in intact rock only thick particles and not the thin particles found by Nadeau et al. (1984) in specimens prepared from dispersed clay. Ahn \& Peacor found only two types of particles: one with a wavy appearance identified as smectite, and one with straight layers (packets) identified as illite. The identifications were based on the depth-dependant variations in amounts of these particle types and on the amount of potassium determined from analytical electron microscopy (AEM). The absence of thin particles did not conform to the fundamental particle model of Nadeau et al. (1984), and the occurrence of illite and smectite layers in illite and smectite particles, respectively, was against the Markovian particle model (see fig. 2). Klimentidis \& Mackinnon (1986) and Ahn \& Peacor (1986b) used HRTEM on mixed-layer clays and concluded that particles composed of different layers with different interlayer spacings were present in samples prior to dispersion for preparation of oriented X-ray specimens. Ahn \& Peacor proposed therefore that the dispersion technique may be responsible for disruption of interstratified clay particles at smectite layer positions. This conforms with the results of Mering \& Oberlin (1971) and Weir et al. (1960) who found that smectite and allevardite disaggregate into elementary layers when deflocculated in suspension with sodium as the dominating cation. Therefore, interstratified particles with both illite and smectite layers are expected to be present in sediments with interstratified minerals, but they disperse easily at smectite spacings during cation saturation and preparation for X-ray diffraction oriented specimens.

\section{Methods applied to study of mixed- layer clay minerals}

As mentioned above, the existence of mixedlayer clay minerals and the nature of mixed-layering was demonstrated by XRD. The clay mineral definitions based on layer structure and charge (Bailey 1980) have been correlated to XRD on clay specimens saturated with specific cations and intercalated with specific organic compounds (MacEwan \& Wilson 1984). Therefore, most of the investigations of clay mineral diagenesis have been carried out by XRD, supplemented in some cases by chemical dissolution of the clays and calculation of an ideal mineral formula from the elemental composition of the resulting solution. Supplementation of XRD by TEM on shadowed specimens prepared from dispersed clays has, as mentioned above, given rise to the neoformation theory of Nadeau et al. for 
Table 2. Classification of diagenetic stages based on chemical and mineralogical indicators derived from the study of clay minerals. From Foscolos et al. (1976, Table 7).

\begin{tabular}{|c|c|c|c|c|c|c|c|c|c|c|c|c|c|}
\hline \multirow{3}{*}{\multicolumn{2}{|c|}{ Diagenetic Stages }} & \multirow{3}{*}{$\begin{array}{c}\text { Occurrence of } \\
\text { Hydrocarbons } \\
\text { (HC) }\end{array}$} & \multicolumn{5}{|c|}{ Chemical indicators } & \multicolumn{6}{|c|}{ Mineralogical indicators } \\
\hline & & & \multirow[b]{2}{*}{ 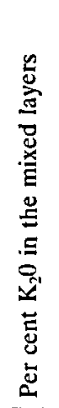 } & \multirow[b]{2}{*}{ 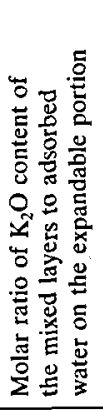 } & \multirow[b]{2}{*}{ 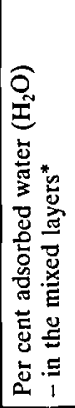 } & \multirow[b]{2}{*}{ 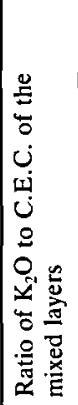 } & \multirow[b]{2}{*}{ 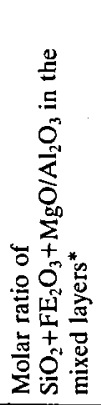 } & \multirow[b]{2}{*}{ 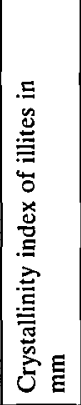 } & \multirow[b]{2}{*}{ 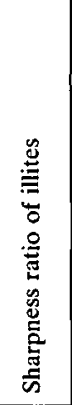 } & \multirow[b]{2}{*}{ 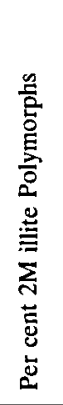 } & \multirow[b]{2}{*}{ 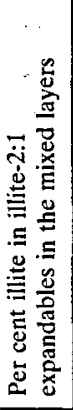 } & \multicolumn{2}{|c|}{$\begin{array}{l}\text { Discrete } \\
\text { layers }\end{array}$} \\
\hline & & & & & & & & & & & & 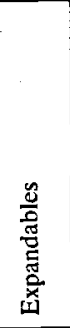 & 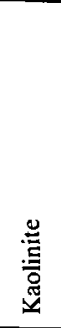 \\
\hline $\begin{array}{l}\text { Eodiagenesis } \\
\text { (Early diagenesis) }\end{array}$ & & $\begin{array}{c}\text { Expulsion of } \\
\text { pore water and } \\
\text { indigenous HC } \\
\text { retention and } \\
\text { decarboxylation } \\
\text { of fatty acids by } \\
\text { clays }\end{array}$ & $<4$. & $<.50$ & $>8$ & $<.10$ & $>5.5$ & N/A $*$ & N/A & N/A & $<25$ & $\begin{array}{l}\text { Pre- } \\
\text { sent }\end{array}$ & $\begin{array}{l}\text { Pre- } \\
\text { sent }\end{array}$ \\
\hline \multirow[t]{2}{*}{$\begin{array}{l}\text { Mesodiagenesis } \\
\text { (Middle diag- } \\
\text { enesis) }\end{array}$} & 젤 & $\begin{array}{c}\text { Ist Interlayer } \\
\text { water removal } \\
\text { from smectite, } \\
\text { inducing acid } \\
\text { properties which } \\
\text { enchance } \\
\text { catalytic crack- } \\
\text { ing of hydrocar- } \\
\text { bons }\end{array}$ & $4-5$ & $\begin{array}{c}0.50- \\
1.00\end{array}$ & 6.7 & $\begin{array}{l}0.10- \\
0.15\end{array}$ & $\begin{array}{l}4.5- \\
5.5\end{array}$ & N/A & N/A & N/A & $\begin{array}{c}25- \\
50\end{array}$ & $\begin{array}{l}\text { Usu- } \\
\text { ally } \\
\text { ab- } \\
\text { sent }\end{array}$ & $\begin{array}{l}\text { Pre- } \\
\text { sent }\end{array}$ \\
\hline & 总 & $\begin{array}{l}\text { 2nd Interlayer } \\
\text { water removal } \\
\text { flushing of } \\
\text { hydrocarbons } \\
\text { from clay } \\
\text { surfaces }\end{array}$ & $5-6$ & $\begin{array}{l}1.00- \\
3.00\end{array}$ & $5-6$ & $\mid \begin{array}{c}0.15- \\
0.20\end{array}$ & $\begin{array}{c}3.5- \\
4.5\end{array}$ & N/A & N/A & N/A & $\begin{array}{l}50- \\
75\end{array}$ & $\begin{array}{l}\mathrm{Ab}- \\
\text { sent }\end{array}$ & $\begin{array}{l}\text { Usu- } \\
\text { ally } \\
\text { ab- } \\
\text { sent }\end{array}$ \\
\hline $\begin{array}{l}\text { Telodiagenesis } \\
\text { (Late diagenesis) }\end{array}$ & & $\begin{array}{l}\text { Production of } \\
\text { non-liquid } \\
\text { hydrocarbons }\end{array}$ & $>6$ & $>3.00$ & $<5$ & $>.20$ & $<3.3$ & $<15$ & $>2.3$ & $>50$ & $>75$ & $\begin{array}{l}\text { Ab- } \\
\text { sent }\end{array}$ & $\begin{array}{l}\text { Ab- } \\
\text { sent }\end{array}$ \\
\hline
\end{tabular}

- Results calculated on air-dry basis

* N/A - not applicable

illite layer formation in mixed-layer illite/smectite. HRTEM investigations on bulk rock led Ahn \& Peacor to discuss the extent to which the XRD and TEM results on dispersed clays can be applied to the mixed-layers in intact bulk rock (see above). The ideal formulae for mixed-layers may be calculated from total elemental analysis of clay fractions. However, spectroscopy (NMR, Mössbauer and IR) yields information on the elemental substitutions in 2:1 layers of illite/ smectite. Spectroscopy of illite/smectites with different amounts of illite layers can therefore indicate which elemental substitutions have taken place during the formation of illite layers from smectite layers. Thus, Eslinger, Highsmith, Albers \& DeMayo (1979) applied Mössbauer spectroscopy to study the role of iron reduction in the increase in negative charge of the 2:1 layer, and Altaner, Weiss \& Kirkpatrick (1988) applied ${ }^{29} \mathrm{Si}$ NMR to investigate the importance of tetrahedral Al for Si substitution during illite layer formation. Altaner et al. (1988) furthermore correlated the NMR results with XRD and discussed the tetrahedral Al substitution in illite and smectite layers. Altogether, it can be seen that a combination of HRTEM on intact bulk rock with 
XRD and TEM on dispersed clays yields important information on the layer-by-layer structure of the mixed-layers in a specimen. The overall elemental composition of illite/smectite is determined by total elemental analysis, but Mössbauer and NMR spectroscopy, although sparsely used so far, yield important information on the substitution pattern of $\mathrm{Fe}, \mathrm{Al}$ and $\mathrm{Si}$ in illite/smectite.

\section{Mixed-layer illite/smectite diagenesis}

\section{Diagenetic stages}

According to Grim (1958) "diagenesis in general terms refers to the changes which may take place when a sediment passes from one environment into a second environment, in which it accumulates". Grim wrote that "opinions differ about the place in the sedimentary cycle where diagenesis should be considered to begin and where it should end, and further changes should be considered metamorphic in nature". Frey (1970) investigated the step from diagenesis to metamorphism (greenschist facies) and found that illite/ smectite disappeared and $1 \mathrm{Md}$ illite changed to $2 \mathrm{M}_{1}$ illite in the transition zone, the anchizone. Foscolos et al. (1976) discussed burial diagenetic staging in relation to clay mineralogical transformations. Their conclusions for occurrence and mineralogy of discrete clay minerals and for the amount of expandable layers, interlayer potassium and water are seen in table 2 . This staging has, however, not been used widely later, and the distinction between discrete, expandable layers and expandable layers in mixed layers as seen in $\mathrm{XRD}$ is not generally valid, see paragraph on interstratified clay minerals. Diagenesis in the following will cover the interval from sedimentation to the beginning of the anchizone.

Investigation of the formation of illite layers from smectite layers

The conversion of smectite layers to illite layers with increasing depth of burial was studied in an Eocene Gulf Coast formation by Burst (1959). Since then several investigations of burial sequences, e.g. Perry \& Hower (1970), Hower, Eslinger, Hower \& Perry (1976), Bruce (1984), found the same conversion of smectite layers with depth. This conversion has also been found to occur during relatively short-lived heating during overthrusting, e.g. Hoffman \& Hower (1979) and in hydrothermally altered material, e.g. Horton (1985). It is difficult to deduce the composition of the starting material and the role of time, temperature and pressure in the geological processes. Laboratory tests have therefore been carried out with well defined mineralogical and chemical reagents, at specified temperatures and for a specified time, e.g. by Eberl \& Hower $(1976,1977)$. The temperatures in these experiments were $250^{\circ}$ to $500^{\circ} \mathrm{C}$, at least $100^{\circ} \mathrm{C}$ more than the temperatures of the smectite to illite layer conversion during burial diagenesis (see below). At a lower experimental temperature, reaction rates were insignificant. The temperatures during overthrusting and during hydrothermal smectite-toillite layer reactions are also higher than the normal temperatures of burial diagenesis. The mixed-layer conversions in the Central Trough and the Norwegian-Danish Basin have occurred during burial diagenesis. Therefore, the literature on the burial diagenetic reaction for conversion of smectite layers to illite layers in mixedlayer illite/smectite will be reviewed in the following together with some of the results from hydrothermal and metamorphic areas and from experiments.

\section{Illitization of illite/smectite during burial diagenesis}

Use of the X-ray diffractometer revealed that mixed-layer minerals are common clay constituents in burial sequences. When the data from clay mineralogical analysis are presented the question each time is: what minerals are detrital (or inherited) and what changes have they undergone? Or alternatively: how liable are the clay minerals to diagenetic alterations and can they be used as diagenetic indicators? Weaver (1958 a and b) went so far as to suggest that shales and clay minerals are largely detrital in nature and have not suffered a great deal of chemical modification. He discussed the clay petrology of Upper Mississippian-Lower Pennsylvanian sediments of Central United States and considered the clay mineralogy of these sediments, even variations 

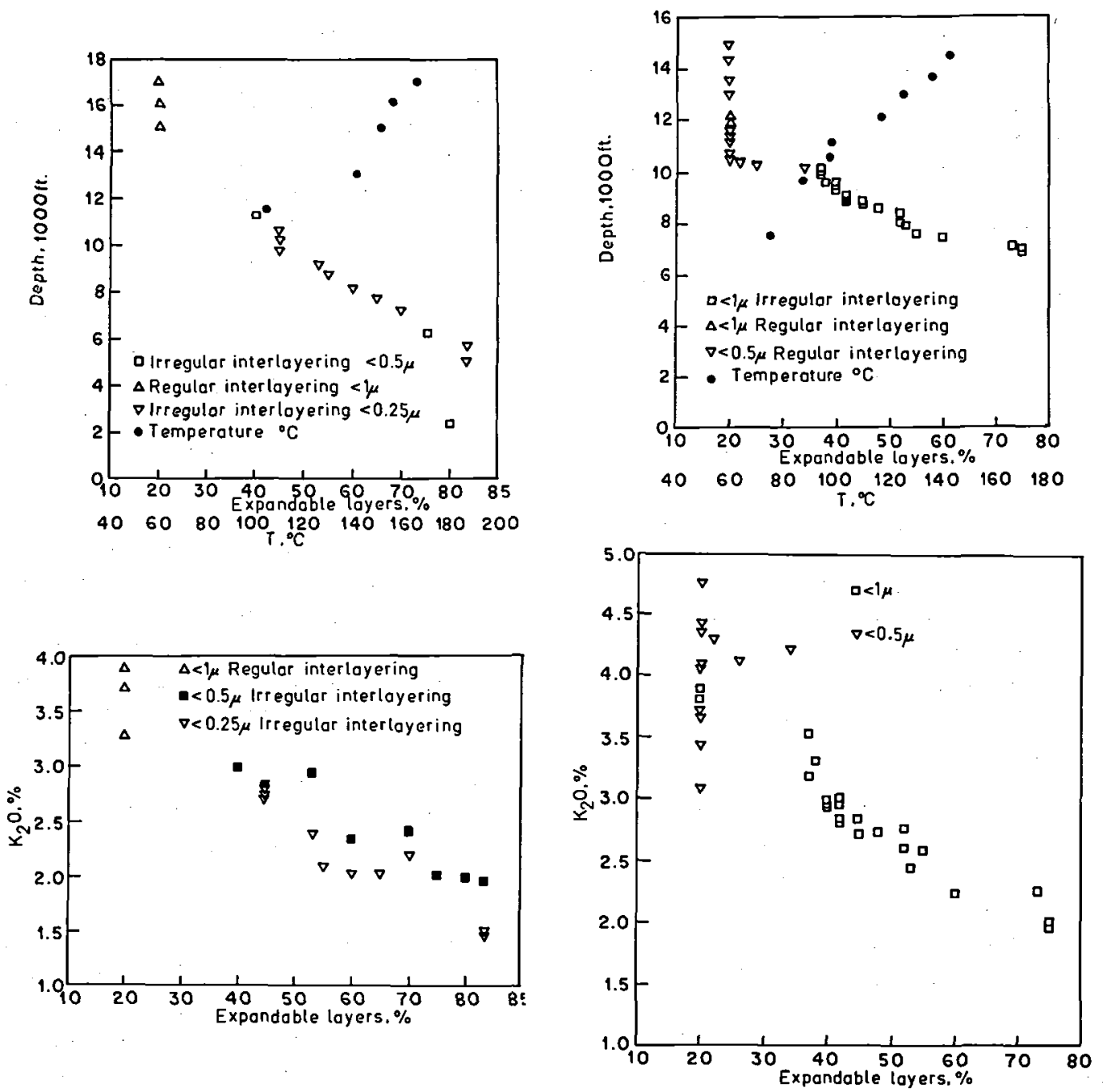

Fig. 3. Illitization of illite/"montmorillonite" (smectite) in U.S. Gulf Coast sediments. After Perry \& Hower (1970, figs. 6 and 7). a: The relationship between \% expandable layers in illite/montmorillonite and sample depth and temperature in Gulf Coast Oligocene to Eocene sediments in well B. b: The relationship between $\% \mathrm{~K}_{2} \mathrm{O}$ in clay-size fraction and $\%$ expandable layers in illite/ montmorillonite in well B. c: Relationship between \% expandable layers in illite/montmorillonite and sample depth and temperature in Gulf Coast Oligocene sediments in well E. $d$ : The relationship between $\% \mathrm{~K}_{2} \mathrm{O}$ in clay size fraction and \% expandable layers in illite/montmorillonite in well $\mathrm{E}$.

with depth in proportions of illite in illite/smectite mixed-layers, to be due solely to different sources and to different weathering conditions.

The first indication of a diagenetic change in mixed-layers was noted by Burst (1959) in Eocene Gulf Coast sediments. He found that montmorillonite became less evident below $10000 \mathrm{ft}$, but was interspersed (mixed-layered) with illite at depths between $3000 \mathrm{ft}$ and $14000 \mathrm{ft}$. In general he noted a progressive loss of expandable material with depth. Weaver (1959) reviewed the literature on clay mineralogy of recent sediments and considered most of the clay mineral changes to be due to detrital variations. He also discussed the depth related changes in clay mineralogy in Gulf Coast Miocene and Oklahoma Upper Mississippian shales and found it probable that montmorillonite below a depth of $10000 \mathrm{ft}$ gave way to mixed-layer illite/montmorillonite with the proportion of illite increasing with depth. Weaver argued that this increase could be related to environment as well as to depth of burial.

The modelling of MacEwan $(1956,1958)$ and of MacEwan \& Amil (1959) made it possible to 
deduce structural layer changes in mixed-layer minerals from XRD patterns. The results of this modelling were applied by Burst (1969) to analysis of the $002 / 003$ illite/smectite peak migration with change in composition of smectite/illite mixed-layers. He calculated that Gulf Coast Eocene sediments contained about $15-20 \%$ illite in mixed-layers in the depth interval: $2600 \mathrm{ft}-8500$ $\mathrm{ft}$. The illite percentage then increased to $65 \%$ at $12500 \mathrm{ft}$, and from that depth no further reduction in expandable layers was apparent. The temperature at $8500 \mathrm{ft}$ was $210^{\circ} \mathrm{F}\left(99^{\circ} \mathrm{C}\right)$ and at 12500 ft $275^{\circ} \mathrm{F}\left(135^{\circ} \mathrm{C}\right)$. Weaver $(1960)$ compared clay mineral data with log values for density and velocity from two Tertiary sections of the Texas Gulf Coast and from an Upper Mississippian shale of Oklahoma and found a similar clay suite and a similar diagenetic change with depth in all three sections. He concluded that time does not appreciably influence the rate of conversion of montmorillonite to illite.

Weaver \& Beck (1971) investigated PlioceneMiocene Gulf Coast muds and found that the percentage of illite layers and the ordering of the illite/montmorillonite increased with depth. They concluded from XRD and chemical investigations that the mixed-layers had a third component, chlorite, which increased in amount with depth. The well investigated bottomed at $16450^{\prime}$, where the temperature was $119^{\circ} \mathrm{C}$. In the interval $1000^{\prime}-16450^{\prime}$ there was a minor increase in the proportion of $10 \AA$ layers in the mixed layers, but the major change appeared to be an increase in the regularity of mixed-layering. They found similar trends with increasing depth in Mississippian shales (Carboniferous) from Oklahoma, but these shales showed a more advanced stage of diagenesis (more illite and chlorite layers in the deeper samples). The deepest Mississippian shales, from $23800^{\prime}$ and at a temperature of $170^{\circ} \mathrm{C}$, still contained mixed-layers with some montmorillonite layers.

Perry \& Hower (1970) investigated Gulf Coast Pleistocene to Eocene shales by XRD and chemical analysis and found a monotonous decrease from $80 \%$ to $20 \%$ of expandable layers in illite/ montmorillonite with depth and that the interstratification changed from random to ordered at about $35 \%$ expandable layers (fig. 3). However, in one well discrete illite decreased with depth in the whole rock, whereas potassium in illite/mont- morillonite increased. They found in well E (fig. $3 c)$ that the decrease of expandable layers from $75 \%$ to $35 \%$ took place from $55^{\circ} \mathrm{C}$ to $95^{\circ} \mathrm{C}$ and that expandability decreased from $35 \%$ to $20 \%$ expandable layers over a short depth interval when the ordering temperature was reached. The composition of random illite/smectite changed rapidly with temperature, but IS ordered illite/ smectite persisted over a broad temperature range (fig. 3). Dunoyer de Segonzac (1970) considered the transformation of montmorillonite to be mainly influenced by depth of burial because of the role of pressure in the dehydration process, but he stressed the importance of the chemical composition of the interstitial solutions. Heling \& Teichmüller (1974) reported the first mixed-layers in the Tertiary of Oberrheingraben at a vitrinite reflectance of $0.4 \% \mathrm{R}_{\mathrm{o}}$. For comparison they also carried out analyses on samples from the Tertiary of Louisiana, where they found that montmorillonite disappeared at a vitrinite reflectance of $0.5 \% R_{o}$ and at a depth of about $1000 \mathrm{~m}$. They concluded that, besides temperature and potassium availability, the duration of heating was also important, whereas the depth of burial was of no importance, and that mixed-layer transformations were slower than the coalification process. However, Heling \& Teichmüller (1974) based their mixed layer investigation on (001) reflections or $(001)_{\mathrm{I}} /(001)_{\mathrm{S}}$ scatter interference peaks in glycolated specimens. Thus a $17 \AA$ reflection was assigned to montmorillonite and a high background between $10 \AA$ and $17 \AA$ to disordered mixed-layer illite/montmorillonite. A discrete $10 \AA$ peak was thus probably assigned to discrete illite. But $10 \AA$ and $17 \AA$ peaks are, in accordance with Reynolds \& Hower (1970), also due to illite and montmorillonite layers in mixed layers. Therefore, the results of Heling \& Teichmüller (1974) may be due to an increasing amount of illite layers in mixed-layers which, for the temperature range $40^{\circ} \mathrm{C}$ to about $175^{\circ} \mathrm{C}$, is more in accordance with the results discussed below.

Foscolos \& Stott (1975) investigated Lower Cretaceous Formations in Canada and proposed 3 diagenetic stages (early, middle, and late) based on the illite crystallinity index of Kubler, the illite sharpness ratio of Weaver, $\% 2 \mathrm{M}_{1}$ illite and on \%illite in mixed-layers. The early diagenetic stage had less than $20-25 \%$ illite in mixed- 


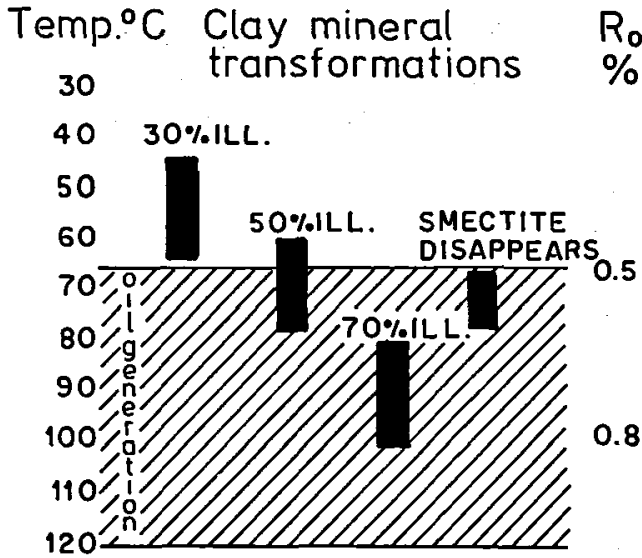

130

140

Fig. 4. Clay mineral transformations and their relationship to temperature and vitrinite reflectance values in Tertiary and Mesozoic sediments in 10 North Sea wells. After Dypvik (1983, fig. 4).

layers, the middle diagenetic stage less than $80-90 \%$ illite in mixed layers, and the randomly interstratified minerals were absent in the late diagenetic stage. Powell, Foscolos, Gunther \& Snowdon (1978) found the onset of changes in mixed-layers in Tertiary to Jurassic sediments to correspond to a vitrinite reflectancy of $0.5 \% \mathrm{R}_{\mathrm{o}}$. An elaborate subdivision of the diagenetic stages based on clay mineralogy was proposed by Foscolos et al. (1976) and is presented above in table 2.

Hower et al. (1976) investigated Gulf Coast Oligocene- Miocene sediments by XRD and chemical analysis. They found with increasing depth: a) a conversion of smectite layers to illite layers in mixed-layer illite/smectite (see fig. 6a), b) an appearance of chlorite and c) a disappearance of potash feldspars. They suggested that the chlorite had formed from magnesium and iron released by the formation of illite layers from smectite, and that released silica had formed quartz. Their results confirmed the persistence from $100^{\circ} \mathrm{C}$ to $175^{\circ} \mathrm{C}$ found by Perry \& Hower (1970) of IS ordered illite/smectite with $80 \%$ illite layers. Hower et al. (1976) used bottom hole temperatures, and corrections of these temperatures by Freed \& Peacor (1989) increased the value from about $100^{\circ} \mathrm{C}$ to about $115^{\circ} \mathrm{C}$. Freed \& Peacor found that the depth for occurrence of the ordered illite/smectite was larger for cuttings alone than for a mixture of cuttings and cores from the same well. They attributed this to mixing of silt and sandstone cuttings with the shale cuttings, because sandstone and siltstone layers are common in the Tertiary Gulf Coast shales and illite/smectite in coarse lithologies tend to have larger illite layer percentages than in adjacent shales (Boles \& Franks 1979). Hower et al. (1976) reported from deeper Gulf Coast Wells that non-interlayered illite formed at about $200^{\circ} \mathrm{C}$. Investigations by Maxwell \& Hower (1967) and Eslinger \& Savin (1973) of metamorphic sequences in Montana and Idaho showed that recrystallization to a $2 \mathrm{M}_{1}$ dioctahedral mica took place at $200^{\circ} \mathrm{C}$ to $300^{\circ} \mathrm{C}$ giving the argillite to phyllite transition.

Dypvik (1983) correlated clay mineral changes with temperature for Tertiary and Mesozoic North Sea samples. The illite/smectite mixedlayer composition changed as follows in 10 wells (see fig. 4): more than $30 \%$ illite layers above temperatures ranging from $45^{\circ}$ to $65^{\circ} \mathrm{C}$, more than $50 \%$ above $60^{\circ}$ to $75^{\circ} \mathrm{C}$, and more than $70 \%$ above $80^{\circ}$ to $100^{\circ} \mathrm{C}$.

Srodoń (1984) investigated low-temperature diagenesis in samples from the Carpathian foredeep (0-200 $\mathrm{m}$ depth) and concluded that the rate of illitization of expandable clay during subsurface diagenesis is too low to produce detectable variation of illite/smectite over a time scale of millions of years, and that smectite and smectiteillite are stable in marine sediments until the high temperatures of deep diagenesis are reached. Srodoń cited Perry \& Hower (1970), Hower et al. (1976), and Pearson, Watkins \& Small (1982) that diagenetic illitization begins at about $50^{\circ} \mathrm{C}$, usually more than $1000 \mathrm{~m}$ below surface.

Srodon \& Eberl (1984, fig. 21) plotted literature data for the smectite to illite transformation in shales from different sedimentary basins as a function of temperature. The basins were: Central Poland (Carboniferous); Douala Basin (Cretaceous); North Sea (Lower Tertiary through Cretaceous); and US Gulf Coast (Tertiary). Weaver (1988) concluded that these curves for the different basins clustered fairly well, except for the data from Central Poland. He received, however, personal communication (in 1988) from Srodon that $1.7 \mathrm{~km}$ of Cretaceous rocks lately were found to have been eroded and then the curve for Poland falls on trend with the others. "This illustrates the type of pitfalls that exist in 
interpretative shale petrology" (Weaver, 1988, p. 426, 1. 15).

Ramseyer \& Boles (1986) investigated mixedlayers in the Tertiary of the San Joaquin Basin in California. Relative to what was found in the Gulf Coast shales at the same temperature they found a high amount of smectite in mixed-layers and explained it by the shorter duration of heating in the San Joaquin Basin compared to the Gulf Coast. They also found that when the reaction forming illite from smectite layers begins it goes to completion within a relatively short temperature interval $\left(80-140^{\circ} \mathrm{C}\right)$.

Primmer \& Shaw (1987) analysed Gulf Coast Tertiary samples and North Sea Lower Cretaceous and Upper Jurassic samples from the Magnus and Brae Fields by XRD of clay fractions and by scanning electron microscopy (SEM) and microprobe analysis on polished thin sections. They found abrupt changes in the degree of ordering in illite/smectite with stratigraphic position and proposed that the compositional changes in the North Sea could be due to differences in source material. They noted that the Gulf Coast Basin has undergone a much simpler and more rapid subsidence than the North Sea Basin and that such differences may manifest themselves in the diagenetic history of the sediments. They concluded from the SEM and microprobe investigations that closed microenvironments existed within the shales. Different diagenetic processes had taken place in these microenvironments, e.g. the formation of authigenic chlorite and kaolinite but also changes in feldspar, carbonate and sulfide phases. In two Gulf Coast samples they calculated structural formulae for chlorite and illite/ smectite from the microprobe data. These formulae must, however, be considered of limited value because 1) The single mineral phases are much smaller in dimensions (see e.g. Ahn \& Peacor (1987), who found kaolinite a few hundred $\AA$ thick in illite crystals) than the smallest spot dimensions of the microprobe; 2) No distinction can be made between elements in the mineral phase and in the fluid phase; and 3) The accuracy of tetrahedral $\mathrm{Al}$ is low, as it is obtained from the amount of tetrahedral $\mathrm{Si}$ (which is about 5 times larger) and an ideal tetrahedral cation population of 4 per 10 oxygen atoms.

Burtner \& Warner (1986) investigated Lower Cretaceous Rocky Mountain shales by XRD.
They cited Rettke who in an investigation from 1981 of adjacent Cretaceous shales found ordered, low-expandable illite/smectite in many samples that had never experienced significant heating. Rettke also found according to Burtner \& Warner that a wide range in expandabilities at low borehole temperatures was significantly reduced above $60^{\circ} \mathrm{C}$ and that only low expandable illite/smectite was present above $90^{\circ} \mathrm{C}$. Burtner $\&$ Warner found an abrupt change from randomly to IS ordered illite/smectite at about $100^{\circ} \mathrm{C}$, at about $80 \%$ illite layers. They also cited Foster and Costard who in investigations from 1982 and 1983 found that burial diagenetic sequences with abrupt changes in percent smectite layers in illite/ smectite contain smectite layers with a low charge produced by divalent cation substitutions in the octahedral sheet. Burtner \& Warner wrote that this type of illite/smectite is common in Tertiary strata of the Gulf Coast, and that profiles marked by a more gradual increase in the illite/smectite ratio with depth possess a higher lattice charge produced by tetrahedral $\mathrm{Al}$ for Si substitution. Burtner \& Warner concluded that the abrupt change in illite/smectite in their samples could be due to smectite layers of predominantly low charge, but that such an abrupt change in illite/ smectite expandability might also be due to a high geothermal gradient. They correlated percentage of expandable layers in illite/smectite to $\mathrm{T}_{\max }$ from Rock Eval analysis and found that the samples above $T_{\max }$ of $437^{\circ} \mathrm{C}$ only contained ordered low expandable illite/smectite $\left(T_{\max }\right.$ of $435^{\mathrm{C}}$ being the top of the oil generative zone for type II and type III kerogen (Espitalie, Madec, Tissot, Menig \& LePlat 1977))

Chang, Mackenzie \& Schoonmaker (1986) investigated Cretaceous shales and sandstones from offshore NE Brazil by XRD, SEM, and chemical analysis. They concluded that dioctahedral illite/smectite became ordered between $90^{\circ} \mathrm{C}$ and $110^{\circ} \mathrm{C}$ and trioctahedral chlorite/smectite at $70^{\circ} \mathrm{C}$ in shales. They calculated that chlorite formation in chlorite/smectite occurred through $\mathrm{Al}$ for Si substitution in the tetrahedral sheets of the trioctahedral saponite layers and a loss of interlayer cations, and that the resulting charge was balanced by fixation of hydroxide sheets. Anjos (1986) investigated Cretaceous shales from offshore SE Brazil by XRD. She interpreted from the XRD patterns the smectites 


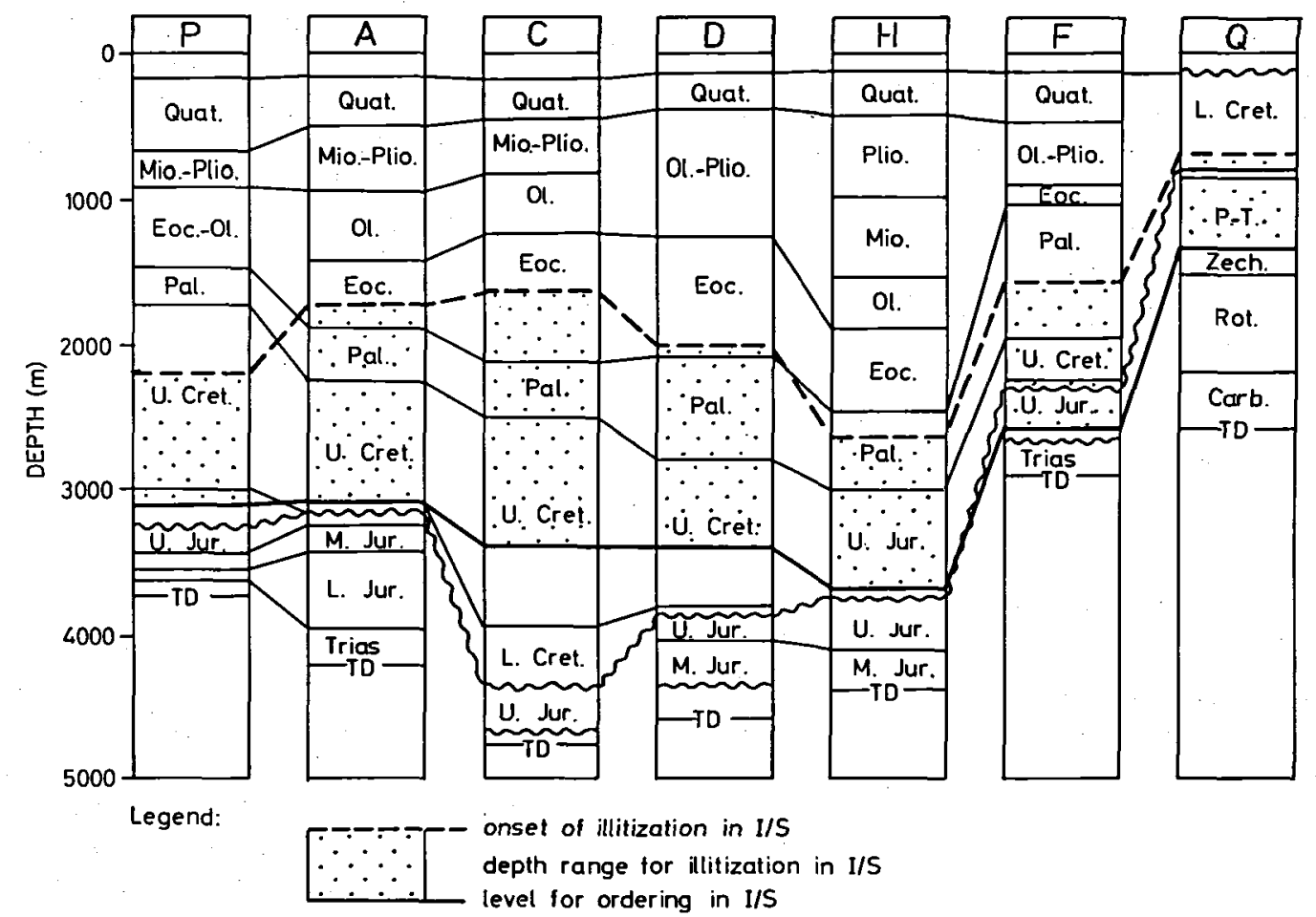

Fig. 5. Comparison of stratigraphy with the depth ranges of illitization south through the Viking Graben (wells $\mathrm{A}-\mathrm{H}$ ) and then east through the Moray Firth Basin (wells F- Q). After Pearson \& Small (1988, fig. 13).

in illite/smectite to be Fe-rich and proposed that this property retarded the illitization of the illite/ smectite.

Pearson \& Small (1988) investigated Quarternary to Triassic shales from the Viking Graben and the Moray Firth by XRD and chemical analysis. They found only randomly ordered or I-S segregated illite/smectite in the shallow buried sediments irrespective of age. The temperatures for the depth where randomly ordered or I-S segregated illite/smectite became IS ordered were $87^{\circ} \mathrm{C}$ to $100^{\circ} \mathrm{C}$, except for one well where it was $125^{\circ} \mathrm{C}$, and vitrinite reflectancy values were $0.54-0.72 \% \mathrm{R}_{\mathrm{o}}$. Pearson \& Small observed that the ordering levels southwards through 5 wells in the Viking Graben and then eastwards through 2 wells in the Moray Firth Basin ran parallel to the Paleocene-Eocene boundary (fig. 5). They interpreted this to mean that the illite/smectite ordering was the result of a Paleocene-Eocene heating event.

Hillier \& Clayton (1989) investigated illite/ smectite diagenesis and organic maturity in lacustrine mudrocks from Northern Scotland. All the illite/smectites contained more than $75 \%$ illite layers and many of them more than $90 \%$. At the same vitrinite reflectancy $\left(0.8-1.0 \% R_{o}\right)$, they found different amounts of illite layers in the Caithness- Orkney region (90-95\%) and in the Moray Firth region (75-80\%) and tentatively attributed the different trends in vitrinite vs. \%illite layers to different burial histories for the two regions.

These various investigations have shown that smectite layers are converted to illite layers in mixed-layer illite/smectite at burial diagenesis, at temperatures above $55^{\circ} \mathrm{C}$, and that illite/smectite become IS ordered at about $100^{\circ} \mathrm{C}$ and at illite percentages of about $80 \%$ in mixed layers. There are, however, indications that the charge and elemental composition of the smectite layers influence the reaction mechanism. An increase in percent illite layers in mixed-layer illite/smectite with increasing temperature has also been found in investigations from metamorphic areas (Hoffman \& Hower 1979, Eslinger et al. 1979, and Środoń 1979) and from hydrothermal areas (Aoyagi \& Kazama 1980, Aoyagi \& Asakawa 1984, and Horton 1985) and mixed-layer illite/ smectite has been synthesized in experiments at 
temperatures of $250^{\circ} \mathrm{C}$ and above. Investigations from metamorphic areas have shown that the increase in percent illite layers in mixed-layer illite/smectite with increasing temperature is very slow compared to the increase in vitrinite reflectancy (Środoń 1979, and Smart \& Clayton 1985). They have furthermore shown that the increase in percent illite layers is larger in shales than in adjacent bentonites (Eslinger et al. 1979), whereas the ordering occurred in the bentonites earlier than in the shales and at a lower illite content than in the shales (Nadeau \& Reynolds 1981a).

Elemental changes in the 2:1 unit during illite layer formation

The formation of illite layers from smectite layers during diagenesis has in many cases only been investigated by XRD.

In the terminology of Millot (1970) the illite may have formed by:

1) an aggradation (fixation of $\mathrm{K}^{+}$between high charge layers);

2) a transformation (formation of high charge by solid-state substitution in smectite layers followed by a $\mathrm{K}^{+}$fixation); or

3) a neoformation (dissolution of smectite layers and recrystallization of illite layers).

Weaver (1958a) postulated that "no mixed layer illite-montmorillonite has been reported, which has a basic lattice character near that of montmorillonite, that is, predominantly octahedral substitution" (p. 261, 1. 16). He believed that mixedlayer clays with a higher charge (than montmorillonite), a larger amount of tetrahedral substitution, and commonly formed in continental deposits, contain hydrated $\mathrm{Ca}^{2+}, \mathrm{Mg}^{2+}$ or $\mathrm{Na}^{+}$as interlayer cations and therefore usually are referred to as montmorillonites or beidellites. The decrease in expandability should then take place when these clays are transported to a marine environment and the high charge layers exchange their $\mathrm{Ca}^{2+}$ for $\mathrm{K}^{+}$and contract to mica-like layers, whereas the lower and octahedrally charged layers remain expanded. Weaver emphasized that, due to the character of the basic lattice, they were mixed-Iayers irrespective of expansion features. Syngenetic alterations, according to Weaver, oc- cur while the clay is still in contact with sea water; epigenetic alterations occur later and eventually pass into low-grade metamorphism. Weaver then reviewed the literature on clay mineralogy of Recent sediments and explained most clay mineral changes found in these to be due to detrital variation. He suggested that montmorillonite type clay predominantly forms from volcanic ash under fresh-water conditions and that in a marine environment, in the presence of potassium, the ash would in many instances, as in Ordovician K-bentonites, go directly to a mixed-layer clay rather than to beidellite. Weaver (1959) stressed that, since no change in basal lattice occurs during the potassium fixation, such fixation should not be termed diagenesis but rather adsorption or exchange. As mentioned above he argued that the decrease of montmorillonite and increase of illite, chlorite and mixed-layer illite-montmorillonite with depth in the Gulf Coast Miocene and Upper Mississippian shales of Oklahoma can be related to environment as well as depth of burial, but concluded that time does not appreciably influence the rate of conversion of montmorillonite to illite. The former support of a sole aggradation process during burial was, however, modified to include the possibility of a transformation: "it remains to be proved whether this (the increase in amount of illite layers in mixed-layers with depth) is caused by chemical modification of the basic lattice with burial or if the detrital clay lattice has the inherent ability to contract without chemical rearrangement when buried to sufficient depth" (p.182, 1.4 from bottom).

Burst (1959) supported an aggradation mechanism in Gulf Coast Tertiary clays. He proposed that the loss of montmorillonite swelling capacity and a simultaneous perfection of chlorite crystal development with depth were the benefications of degraded and fragmental mineral lattices by gradual fixation of potassium and magnesium to form illite and chlorite, respectively.

Powers (1959) proposed two alternatives for the change of montmorillonite to illite: 1: adsorbed $\mathrm{Mg}^{2+}$ and $\mathrm{Fe}^{2+}$ may move into the octahedral sheet and replace $\mathrm{Al}^{3+}$, which possibly moves into the tetrahedral sheet expelling $\mathrm{Si}^{4+}$. and $\mathrm{K}^{+}$moves into interlayer positions. 2: a slow interlayer replacement of interlayer $\mathrm{Mg}$ by $\mathrm{K}$. Powers favoured the first possibility, because he believed that an increase in tetrahedral charge of 

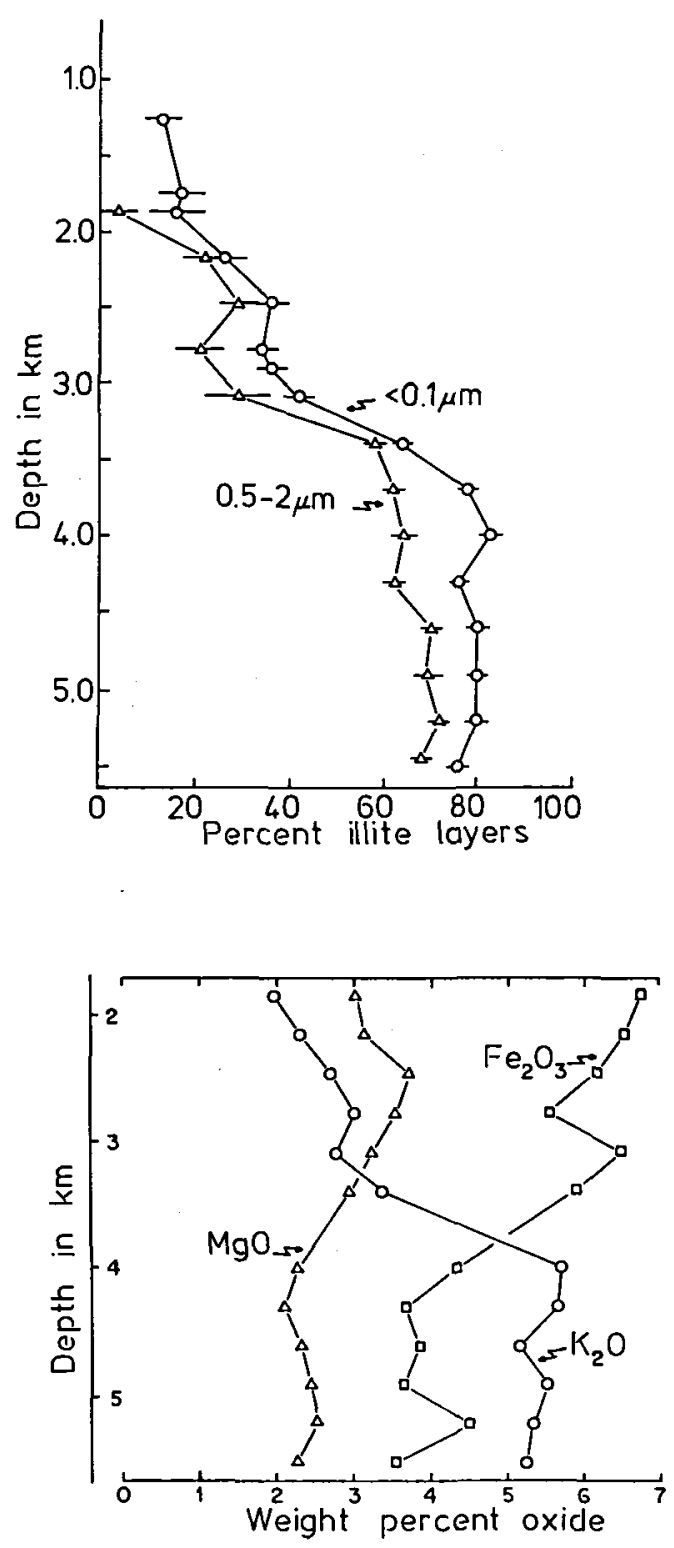

the montmorillonite layers is necessary for $\mathrm{K}$ fixation. Thus Ross \& Hendricks (1945) wrote that the number of non-exchangeable interlayer ions in montmorillonites, essentially of $\mathrm{K}^{+}$, increases with degree of tetrahedral substitution of Si by Al. Hower \& Mowatt (1966) and Weaver \& Pollard (1973) noted that illite and smectite layers in mixed-layers may well differ in composition. Hower (1967) found that a mixed-layer illite/montmorillonite of a given bulk composition can have a wide range of expandabilities depend-
Fig. 6. Illitization of illite/smectite in U.S. Gulf Coast Miocene to Oligocene sediments, Case Western Reserve University Gulf Coast well 6, after Hower et al. (1976). a: Percent of illite layers in illite/smectite as a function of depth in the finest and coarsest clay fractions, after fig. 3 of Hower et al. (1976). b: Depthdependance of the $\mathrm{K}_{2} \mathrm{O}, \mathrm{MgO}, \mathrm{Fe}_{2} \mathrm{O}_{3}, \mathrm{Al}_{2} \mathrm{O}_{2}$, and $\mathrm{SiO}_{2}$ content of the less than $0.1 \mu \mathrm{m}$ fraction, after Hower et al. (1976, fig. 9 and 10 ).
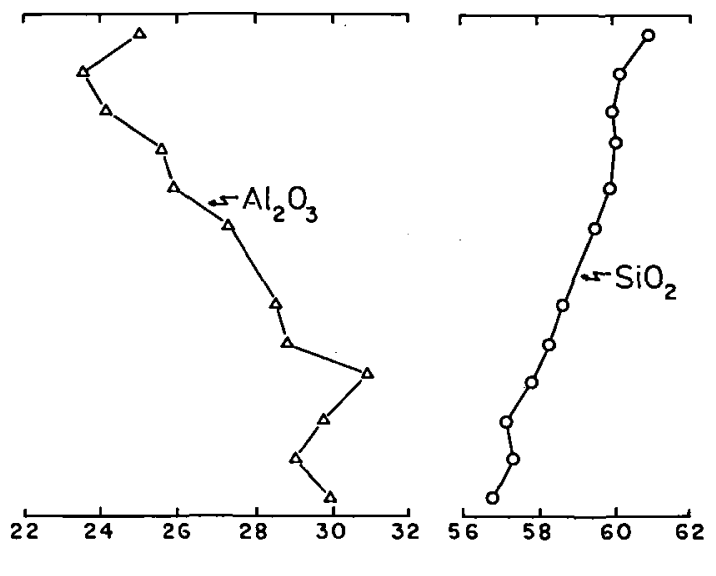

ing on the amount of ordering. Burst (1969) proposed, however, that the change of montmorillonite layers to illite layers was a physical process, during which interlayer water with depth acquired sufficient thermal energy to be released.

Then followed a series of publications, mostly based on XRD and chemical investigations of illite/smectite from burial sequences. Their conclusions were generally in support of the transformation mechanism. Dunoyer de Segonzac (1970) proposed that, during the montmorillonite 
$\rightarrow$ mixed-layer illite/montmorillonite $\rightarrow$ illite transition, $\mathrm{Al}^{3+}$ should leave octahedra and be replaced in octahedra by $\mathrm{Mg}^{2+}$. Pollard (1971) found that the transformation of montmorillonite to illite involved an increase in tetrahedral substitution of $\mathrm{Al}$ for Si from about $0 \%$ to $20 \%$ and that the degree of $\mathrm{Al}$ substitution is $1 / 6$ of $\mathrm{Si}$ at the time when the illite type lattice is formed. Weaver \& Beck (1971) investigated samples from shallow depths (less than 1000') in areas with relatively low geothermal gradients. They found indications that $\mathrm{K}$ had migrated into the highly charged expandable layers and caused contraction of these layers to $10 \AA$ at shallow depths of burial and concluded that it was unlikely that much structural rearrangement occurred at these depths. Weaver \& Beck proposed that interlayer $\mathrm{Al}^{3+}$ at larger depths of burial $\left(>10000^{\prime}\right)$ could migrate into the tetrahedral sheet of montmorillonite layers to substitute for $\mathrm{Si}^{4+}$ and increase layer charge when the temperature becomes high enough. They proposed alternatively that $\mathrm{Al}$ and Si tetrahedra might form illitic rims at the edges of montmorillonite flakes but they considered this alternative unlikely. According to Weaver \& Beck, the Al required for tetrahedral substitution might originate from kaolinite and/or feldspar. Hower et al. (1976) found in their investigation of Eocene-Pleistocene Gulf Coast shales that the formation of illite from smectite layers in illite/ smectite was accompanied by a gain in $\mathrm{Al}$ and $\mathrm{K}$ and a loss of $\mathrm{Si}$ and, to a minor degree, of $\mathrm{Fe}$ and Mg (fig. 6). They believed the process to be a solid-state transformation with a tetrahedral charge increase through $\mathrm{Al}$ for $\mathrm{Si}$ substitution accompanied by interlayer fixation of $\mathrm{K}$ :

smectite $+\mathrm{Al}^{3+}+\mathrm{K}^{+}=$illite $+\mathrm{Si}^{4+}$

and also accompanied by octahedral $\mathrm{Al}$ for $\mathrm{Fe}$ and $\mathrm{Mg}$ substitution. Foscolos et al. (1976) concluded from chemical analysis and XRD that $\mathrm{Al}$ substituted for $\mathrm{Si}$ and $\mathrm{Fe}$ and the content of $\mathrm{K}$ increased in the mixed-layers with increasing depth of burial, whereas adsorbed $\mathrm{H}_{2} \mathrm{O}$ decreased.

The transformation mechanism was then further supported by the results of hydrothermal experiments by Eberl (1978a, 1978b) and by Eberl \& Hower $(1976,1977)$. Eberl \& Hower (1976) concluded that the rate limiting step in formation of illite layers from smectite was probably an increase in layer charge by tetrahedral substitution of $\mathrm{Al}$ for $\mathrm{Si}$. In their opinion, a significant reaction rate for this step was only obtained at the elevated temperatures during burial diagenesis. Eberl \& Hower (1977) proposed a polarization effect in a 2:1 layer by tetrahedral substitution of $\mathrm{Al}$ for $\mathrm{Si}$ and increase in negative charge of one tetrahedral sheet in the 2:1 unit. This polarization should, according to their proposal, create $50 \%$ expandability, since subsequent tetrahedral substitution in the other tetrahedral sheet of the 2:1 unit should be more difficult. However, the effect on the tetrahedral sheet adjacent to the substituted layer should be less due to the positive interlayer cations.

Investigations of little transformed and of metamorphosed illite/smectite from the disturbed belt of Montana are of interest in relation to structural changes in illite/smectite during diagenesis. Eslinger et al. (1979) found a positive correlation between the percentage of iron as $\mathrm{Fe}^{2+}$ and the amount of fixed $\mathrm{K}^{+}$. The percentage of iron as $\mathrm{Fe}^{2+}$ and the amount of illite layers were not correlated because of the low amount of iron in the samples and the relatively low importance of iron reduction compared to tetrahedral substitution of $\mathrm{Al}$ for $\mathrm{Si}$ in increasing layer charge. They calculated that octahedral iron reduction might have contributed as much as $10-30 \%$ of the increase in total structural charge that occurred during metamorphism of bentonites. Eslinger et al. believed that iron reduction might become more important compared to tetrahedral substitution of $\mathrm{Al}$ for $\mathrm{Si}$ in samples having high percentages of illite layers, since access to a tetrahedral site would be more difficult once the adjacent interlayer space has collapsed. All of their bentonites had, however, been in an "oxidising outcrop" environment for some years. Hoffman \& Hower (1979) found a much higher $\mathrm{Al}$ for Si substitution in smectites from the metamorphic area ( $0.56 \mathrm{Al}$ tetrahedral) compared to the little transformed smectites $(0.09 \mathrm{Al}$ tetrahedral).

Brockamp (1979) found that the conversion of smectite layers into illite layers involved a change of $\mathrm{d}(001)$ in $\mathrm{Mg}$-glycolated specimens, from $17 \AA$ over $14 \AA$ to $10 \AA$, a corresponding increase of tetrahedral $\mathrm{Al}$ from 0.10 to 1.05 per $(\mathrm{OH})_{4} \mathrm{O}_{20}$, and a corresponding increase in fixed $\mathrm{K}^{+}$from 
0.24 to 1.00 . Brockamp placed about 0.20 fixed $\mathrm{Mg}$ per $(\mathrm{OH})_{4} \mathrm{O}_{20}$ in the illite layers of the $14 \AA$ and $10 \AA$ phases.

Frank-Kamenetski, Kotelnikova, Kotov \& Starke (1979) found from hydrothermal experiments that montmorillonites with practically no tetrahedral substitution formed illite only at elevated temperatures and believed the process to take place by transition of $\mathrm{Al}$ from octahedral to tetrahedral positions.

Eberl (1980) proposed that cation selectivity should be a function of layer charge and different cations should therefore segregate into separate interlayers in smectites that have an inhomogeneous layer charge distribution (low and high charge interlayers).

Boles \& Franks (1979) investigated interbedded shales and sandstones of Eocene age from the Gulf Coast by XRD and electron microprobe. Mass balance calculations based on their own data and on those of Hower et al. (1976) led Boles \& Franks to propose that the more aluminous smectite layers should transform into illite layers by $\mathrm{Al}$ for $\mathrm{Si}$ substitution and $\mathrm{K}$-fixation during the increase in amount of illite layers in randomly ordered illite/smectite. The more $\mathrm{Mg}$ and $\mathrm{Fe}$ - containing smectite layers should during this stage either dissolve and thereby release $\mathrm{Al}$ for the smectite to illite transformation of the more aluminous layers and $\mathrm{Fe}, \mathrm{Mg}$, and $\mathrm{Si}$ for growth of other minerals or they should not undergo transformation to illite until the temperature of ordering. If this is correct, the amount of mixed-layer illite/smectite will decrease during diagenesis. Hower (1981b, p.68, 1.29) commented on the calculations as follows: "Assuming that the analyses are sufficiently accurate to draw a conclusion, their (Boles and Franks) suggestion may be correct."

Howard (1981) investigated shales and adjacent sandstones and found high-charge expandable layers in the shale laminae. From the Greene-Kelley test, the charge of these layers was probably due to tetrahedral substitution. Tetrahedral $\mathrm{Al}$ increased with progressive illitization, whereas octahedral Al remained essentially constant. He concluded that the illitization reaction probably was a step-wise process, first a creation of a high layer charge in the expandable layers by lattice substitutions and subsequently a fixation of $\mathrm{K}^{+}$within the interlayers. He be- lieved, therefore, that creation of a high layer charge did not guarantee $\mathrm{K}^{+}$-fixation and illite formation.

Pearson et al. (1982) compared two shallow Upper Jurassic samples from the Inner Moray Firth with two deeply buried Upper Jurassic samples from the Viking Graben and took a greater content of $\mathrm{K}$ and $\mathrm{Al}$ and a lower content of $\mathrm{Si}$ in the Viking Graben samples as indicating that a pronounced depletion of $\mathrm{Si}$ and enrichment of $\mathrm{K}$ and $\mathrm{Al}$ occurred during burial.

Ireland, Curtis \& Whiteman (1983) investigated glauconites and illite in mudstones and sandstones of low diagenetic to greenschist facies and concluded that both groups evolved during diagenesis into phengite by tetrahedral $\mathrm{Al}$ for $\mathrm{Si}$ substitution together with octahedral $\mathrm{Al}$ for $\mathrm{Fe}^{3+}$ substitution. Inoue \& Utada (1983) found in a hydrothermal area that degrees of ordering changed discontinuously from R0 ordering (100-55\% expandable layers) to R1 (45-20\% expandable layers) and from R1 to R2 ( $<20 \%$ expandable layers). This was different from the published transformations in burial sequences, where a continuous change in ordering type is seen in illite/smectite. Compared to the published results of burial diagenetic mixed-layers, the hydrothermal mixed-layers had a greater layer charge at a given amount of expandable layers, and Inoue \& Utada proposed that both smectite and illite layers should have a greater charge compared to the same layer types in burial diagenetic samples. These comparatively higher charges for the hydrothermal samples cause dehydration of interlayer $\mathrm{Na}$ and $\mathrm{Ca}$ (these require a larger charge than $\mathrm{K}$ for dehydration, Eberl (1980)), and influence the degree of ordering at a given expandability. Inoue \& Utada suggested from the data that the development of the hydrothermal mica/smectite zone and the progress of the conversion reaction were controlled by the cation composition of hydrothermal solutions as well as by temperature.

Howard \& Roy (1985) found from hydrothermal experiments at both relatively high $\left(250^{\circ} \mathrm{C}\right)$ and relatively low $\left(150^{\circ} \mathrm{C}\right)$ temperature that the creation of a layer charge sufficient to lead to transformation of smectite to illite required no $\mathrm{K}$. Illitization proceeded when $\mathrm{K}$ was introduced to layers with a sufficiently high charge. Analysis of resulting solutions indicated that the substitution 
reaction at $150^{\circ} \mathrm{C}$ proceeded by congruent dissolution of octahedral and tetrahedral sheets. Howard \& Roy suggested that different reaction mechanisms might occur at $150^{\circ} \mathrm{C}$ compared to those at the higher temperatures experimentally investigated earlier:

Horton (1985) found a poor correlation between the amount of illite/smectite and the composition of illite/smectite in a hydrothermal vein. It should be noted that the vein was alkaline and that $\mathrm{K}$ feldspars were present even at $80 \%$ illite in illite/smectite. This means that $\mathrm{K}$ availability was not a limiting factor in illite layer formation.

Pearson \& Small (1988) concluded from chemical analysis of fine-clay fractions $(<0.4 \mu \mathrm{m})$ from the Viking Graben that increasing $\mathrm{K}$ fixation in interlayer sites of illite/smectite mixedlayers was accompanied by increasing substitution of $\mathrm{Al}$ for $\mathrm{Si}$ in tetrahedral sites.

These various investigations have shown that $\mathrm{Al}^{3+}$ substitutes in the tetrahedral sheet for $\mathrm{Si}^{4+}$ and that $\mathrm{K}^{+}$is fixed during the diagenetic formation of illite layers from smectite layers. Some of the investigations have also found changes in the octahedral sheet ( $\mathrm{Al}$ substituting for $\mathrm{Mg}$ and $\mathrm{Fe}$; reduction of $\mathrm{Fe}^{3+}$ ). The changes seen during hydrothermal experiments and in hydrothermal areas seem to differ from those seen during burial diagenesis in that higher negative charges are created and that $\mathrm{Na}^{+}$and $\mathrm{Ca}^{2+}$ also are fixed under hydrothermal conditions.

Changes in interlayer cations and potassium fixation during illite layer formation

The hydrothermal experiments mentioned above have shown that specific interlayer cations are dehydrated and fixed when the negative charge of the 2:1 layer becomes sufficiently high. The concentration and type of the cations in the interlayer are therefore important and several investigations have dealt with this subject.

Powers (1959) emphasized the role of chemical composition of interstitial water in clay diagenesis, especially the role of the $\mathrm{Mg} / \mathrm{K}$-ratio, and proposed a model according to which preferential adsorption of $\mathrm{Mg}$ to $\mathrm{K}$ should decrease with depth in marine sediments due to decreasing amounts of $\mathrm{Mg}$ with depth of burial, from the 5:1 ratio found in sea water. Dunoyer de Segonzac
(1970) wrote that the most important process during formation of non expandible layers occurred in the interlayer where water and exchangeable cations should be replaced by nonexchangeable $\mathrm{Na}^{+}$and $\mathrm{K}^{+}$. He predicted mica sheets in regular mixed layers to be rich in $\mathrm{Na}^{+}$ relatively to $\mathrm{K}^{+}$because of the dominance of $\mathrm{Na}^{+}$ in most interstitial solutions. Powell et al. (1978) found that $\mathrm{K}^{+}$was adsorbed on the surface of the clay during the first dehydration of the interstratified clays (illite/vermiculite/smectite). (They probably mean fixed instead of adsorbed). In one well they found a sharp decrease in the molar ratio of $\mathrm{SiO}_{2}+\mathrm{Fe}_{2} \mathrm{O}_{3}+\mathrm{MgO}$ to $\mathrm{Al}_{2} \mathrm{O}_{3}$ at the depth where a change in the $d_{001}$ spacing was observed. Eberl \& Hower (1977) concluded from hydrothermal experiments that potassium as interlayer cation was more readily fixed than sodium because of the lower hydration energy of potassium and that the formation of sodium mica layers therefore required a larger layer charge than did potassium mica-layers. Eberl (1978a) found from further hydrothermal experiments that the greater the hydration energy of the interlayer cation, the greater the charge that must develop in the 2:1-layers to cause dehydration, layer contraction and cation fixation, and therefore the slower the dehydration rate. Eberl (1978a) also found that monovalent cations resulted in a gradual transformation of smectite layers into illite layers. Divalent cations resulted in direct formation of a rectorite-like phase from smectite (there was no gradual increase in amount of illite layers). Potassium fixation is, however, preferred both because dehydrated potassium fits into the hexagonal holes of the tetrahedral sheet and because potassium has the lowest hydration energy (Eberl 1978a). Heling $(1978,1979)$ investigated the illite/smectite mineralogy, the potassium minerals, the specific surface $\left(\mathrm{N}_{2}\right)$, and the pore dimensions (by mercury intrusion) of Tertiary samples from the Rhine Graben. He concluded that although tetrahedral substitution should be important, the major process in the formation of illite layers from smectite is the diffusion of $\mathrm{K}^{+}$ions into the interlayer space of smectite. 
A

B
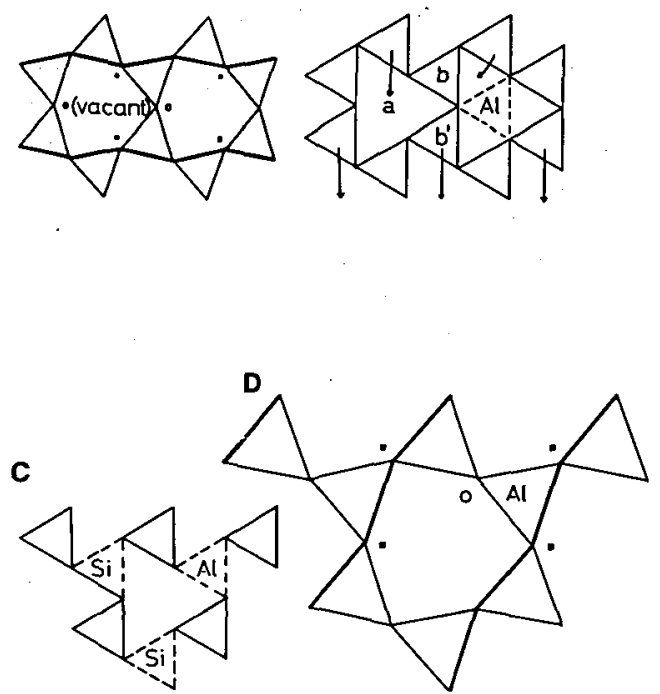

Fig. 7. Model for a solid-state transformation of a single tetrahedral sheet, as proposed by Pollard (1971). Figure and figure captions slightly modified from Pollard (1971, fig. 1).

A: Projection on (001) of the basal faces of tetrahedra in one sheet and of occupied $(\square)$ and vacant $(O)$ octahedral sites for a "montmorillonite" (smectite) layer. Tetrahedral rotation is approximately $12^{\circ}$, and tetrahedra are tilted approximately $5.5^{\circ}$ about the bolder edge. This is the bottom tetrahedral sheet, so that the basal oxygen in each tetrahedron that is not on the bolder edge is slightly clevated.

B: Aluminum has entered some of the "a" sites, causing full rotation of the tetrahedra $\left(30^{\circ}\right)$ and creating the possibility that silicon can be expelled either from the tetrahedral " $b$ " or " $b$ " sites. The "b" expulsion is schematically depicted here. The expelled silicon can migrate along easy paths either to empty "a" sites (straight arrows) or to the interlayer volume (curved arrow), if the neighbouring "a" sites are occupied by aluminum. C: Previous "b" sites are depicted as empty and previous " $a$ " sites are depicted as occupied either by aluminum or by silicon that has migrated from previous " $b$ "" sites. These new (A1, Si) tetrahedra are outlined by dashed lines. The previous " $b$ " tetrahedra are unchanged, still occupied by silicon, and outlined in solid lines. Relaxation from extreme rotation has not occurred yet at this stage.

D: Continued tetrahedral rotation and retilting of tetrahedra yield the bottom tetrahedral sheet of the alteration product, where the corrugations in the basal oxygen plane trend at $120^{\circ}$ from those in the original tetrahedral sheet. The distribution of aluminum over the tetrahedral sites in the alteration product is ordered, and the ratio $\mathrm{Al} / \mathrm{Si}$ in the $(\mathrm{Al}, \mathrm{Si})$ tetrahedra varies from 0 to $1 / 3$ (as depicted) to infinity, depending on the occupancy of the original "a" sites by aluminum when increased tetrahedral rotation was initiated.

Mechanisms for formation of illite layers from smectite layers

Possible mechanisms for formation of illite layers were mentioned in the chapter on elemental changes in the 2:1 layers during illite layer formation. These mechanisms will now be discussed in more detail, in relation to different materials and reaction conditions.

Weaver (1958a) advocated the formation of illite layers as solely aggradation $\left(\mathrm{K}^{+}\right.$- fixation between high-charge, $\mathrm{K}^{+}$- depleted layers). This involves no changes in the substitution pattern of the 2:1 layers and is termed aggradation by Millot (1970).

Van Olphen (1966) investigated the collapse of the interlayer space after heating $\mathrm{K}^{+}$- saturated montmorillonite clays. He found that the ease and degree of this collapse was high for a high degree of tetrahedral substitution and for a high $\mathrm{K}^{+}$population on the unit layer surface. $\mathrm{He}$ also found that a highly crystalline bentonite, probably originating from weathering of mica, showed a higher degree of collapse than did a poorly crystalline bentonite, probably originating from weathering of volcanic ash. After the AIPEA classification, see table 1 , the amount of layer charge determines whether the 2:1 clay layers are smectitic, vermiculitic or micaceous (illitic), and the decrease in expansion following $\mathrm{K}^{+}$-fixation between high-charge layers is therefore a $\mathrm{K}^{+}-$ fixation in illitic layers. The investigations cited above show that the cations in the 2:1 layers are changed during diagenesis and this ruled out the theory of pure aggradation. Therefore, the smectite to illite reaction must occur either as a transformation or a neoformation after the terminology of Millot (1970) (see above).

Pollard (1971) described the formation of illite layers from smectite layers through a transformation. He proposed the following mechanism for solid-state $\mathrm{Al}$ for $\mathrm{Si}$ substitution in tetrahedral sheets (see fig. 7): A slight rotation, approximately $12^{\circ}$, positions 3 of the 6 oxygens of the ditrigonal holes closer to the middle of these holes (fig. 7A). They are therefore attracted by one entering $\mathrm{Al}$ cation and this attraction causes tetrahedral rotation of $30^{\circ}$ so that the basal plane of the tetrahedral sheet looks like in fig. 7B. One $\mathrm{Si}^{4+}$ is then expelled from neighbouring site $\mathrm{b}$, and ordered substitution of $\mathrm{Al}^{3+}$ for $\mathrm{Si}^{4+}$ is obtained by repeating this procedure throughout the tetrahedral sheet. Continued tetrahedral rotation and tilting results in a tetrahedral sheet with ditrigonal holes like those before substitution but with tetrahedra rotated $120^{\circ}$ with respect to the octahedral sheet (fig. 7D). As " $a$ " sites become $\mathrm{Al}$ tetrahedra and " $\mathrm{b}$ " sites are vacated 
by $\mathrm{Si}^{4+}$ ions, protons have to be exchanged from the apical oxygen of the " $b$ " sites to the hydroxyl groups coordinated to the "a" sites. Pollard proposed that $\mathrm{Al}$ from breakdown of kaolinite or feldspar is present as a dissolved species in the interlayer volume of clays and therefore present for migration into the " $a$ " sites. He proposed that the presence of $1 / 3 \mathrm{Al}$ per " $\mathrm{a}$ " site may result in an illite layer after one operation of the proposed mechanism. However, if the ratio of $\mathrm{Al}$ atoms per " $a$ " site is less than one third, the mechanism would be required to operate more than once during diagenesis, such that tetrahedral $\mathrm{Al}$ in one sheet would increase with each operation. Pollard wrote that "in this sense, the montmorillonite-to-illite alteration may represent a segment of the larger metamorphic alteration from montmorillonite to mica, the total process being constructed of smaller semidisplacive steps" (p. 90, 1 . 14 from bottom).

Hower et al. (1976) investigated cuttings from Oligocene-Miocene sediments from the Gulf Coast, USA. They found that the chemical changes in the illite/smectite generally fit the reaction: smectite $+\mathrm{Al}^{3+}+\mathrm{K}^{+} \rightarrow$ illite $+\mathrm{Si}^{4+}$, as suggested by Pollard (1971). Hoffman \& Hower (1979) investigated outcrop samples from Cretaceous shales and bentonites from the Distorted Belt, Montana. They concluded that the reaction during the low metamorphic process in the shales appeared to be the same as that which had been proposed by Hower et al. (1976) for burial diagenetic sequences. In the bentonites, they proposed three different reaction schemes depending on the amount of available potassium and aluminum:

1) No $\mathrm{K}^{+}: \mathrm{X}$-smectite $\rightarrow$ kaolinite + quartz + $\mathrm{X}^{+}$

2) Limited $\mathrm{K}^{+}: \mathrm{K}^{+}+\mathrm{X}$-smectite $\rightarrow$ illite/smectite + quartz $+\mathrm{K}^{+}+$kaolinite

3) Unlimited $\mathrm{K}^{+}: \mathrm{K}^{+}+\mathrm{X}$-smectite $\rightarrow$ illite/smectite + quartz $+\mathrm{X}^{+}$

( $\mathrm{X}$-smectite is smectite with the exchangeable cation $\mathrm{X}^{+}$)

Hoffman \& Hower (1979) did not discuss the mechanisms in these reactions. However, the initial formation of smectite from the volcanic ash in the bentonites must have occurred through dissolution of the ash and crystallization of the smectite layers. The formation of kaolinite and quartz under conditions of limited or no available potassium must also occur from aluminum and silicon dissolved from the smectite layers. The complete conversion of smectite to kaolinite when no potassium is available is therefore a complete neoformation mechanism. The conversion of smectite to illite in shales during burial diagenesis (Hower et al. 1976) or metamorphism (Hoffman \& Hower 1979) was considered a transformation mechanism, mainly occurring through $\mathrm{Al}^{3+}$ for $\mathrm{Si}^{4+}$ substitution in the tetrahedral sheet.

Eberl \& Hower (1976) carried out hydrothermal experiments on the smectite $\rightarrow$ illite reaction. They concluded that the activation energy calculated for the reaction probably represented the energy required to break chemical bonds in the tetrahedral sheet so that $\mathrm{Al}^{3+}$ can substitute for $\mathrm{Si}^{4+}$. Eberl \& Hower (1977) concluded that in nature the mechanism of illite layer formation can be related to the hydration energy of potassium. The mechanism proposed to occur in nature is that $\mathrm{Al}^{3+}$ substitutes for $\mathrm{Si}^{4+}$ in the tetrahedral sheet at high temperatures in the sediments. When the layer charge during this reaction has become sufficiently high, interlayer potassium dehydrates, the interlayer space contracts irreversibly and illite layers have formed. Sawhney (1967) suggested that polarization of electron densities in the 2:1 layer towards the mica interlayer should take place because of the shorter distance between a dehydrated cation and the surface of the tetrahedral sheet in the $2: 1$ layer facing the adjacent interlayer. This polarization would then make the tetrahedral sheets adjacent to the expanded interlayers effectively less negative. Such less effectively negative tetrahedral sheets will, according to Eberl \& Hower (1977), require more substitution of $\mathrm{Al}^{3+}$ for $\mathrm{Si}^{4+}$ to develop sufficient negative charge to dehydrate the interlayer cation. Furthermore, the polarization effect may make $\mathrm{Al}^{3+}$ substitution in the other tetrahedral sheet of a 2:1 layer more difficult when one tetrahedral sheet has acquired a negative charge through $\mathrm{Al}^{3+}$ for $\mathrm{Si}^{4+}$ substitution. Thus, the polarization effect may, according to Eberl \& Hower (1977), favour ordering of illite and smectite layers in illite/smectite. Depending on the degree of substitution in a tetrahedral sheet, ordering may be IS (high charge 
from tetrahedral substitution) or ISI (lower charge from tetrahedral substitution, so that polarization from two layers is required to prevent $\mathrm{Al}^{3+}$ for $\mathrm{Si}^{4+}$ substitution in adjacent 2:1 layers) (Eberl \& Hower 1977). The reactions at the elevated temperatures $\left(260^{\circ}-490^{\circ} \mathrm{C}\right)$ of the hydrothermal experiments together constitute a solidstate transformation mechanism and the polarization from such a solid-state $\mathrm{Al}^{3+}$ for $\mathrm{Si}^{4+}$ substitution can result in ordering (IS or ISI) of the formed illite/smectite.

Roberson \& Lahann (1981) found that $\mathrm{K}^{+}$saturation of natural montmorillonites resulted in a decrease in the amount of expandable layers and suggested that these minerals possessed layers with sufficient charge to fix $\mathrm{K}^{+}$from solution without heating. Roberson \& Lahann treated the montmorillonites hydrothermally at $270^{\circ} \mathrm{C}$ and $350^{\circ} \mathrm{C}$. TEM showed that the formed illite/smectite did not differ in morphology or size from the starting montmorillonites and this was taken by Roberson \& Lahann to be "not inconsistent with a solid-state transition of smectite to illite". Initially, there was no $\mathrm{Al}$ in the solution so Roberson and Lahann concluded that the $\mathrm{Al}$ necessary for illite layer formation was derived from the breakdown of other smectite layers.

Howard \& Roy (1985) heated a sodium saturated bentonite hydrothermally at $150^{\circ} \mathrm{C}$ and $250^{\circ} \mathrm{C}$ to investigate the importance of $\mathrm{K}^{+}$- deficiency for creation of charge in the 2:1 layers during hydrothermal conversions. They found in the $150^{\circ}$ experiment that $\mathrm{Al}, \mathrm{Si}$ and $\mathrm{Mg}$ appeared to be released stoichiometrically with respect to the original smectite composition. They took this to indicate the formation of high-charge layers through a dissolution mechanism. No illite layers were formed in the reactions, but only highcharge layers which contracted to $10 \AA$ after $\mathrm{K}^{+}$saturation and glycolation. This was contrary to the solid-state transformation previously proposed for interlaminated sandstones and shales by Howard (1981).

Whitney \& Northrop (1988) carried out hydrothermal experiments on the smectite to illite reaction. $\mathrm{K}^{+}$- saturated standard smectites from the Clay Minerals Society were treated at 250 $450^{\circ} \mathrm{C}$. The products were examined by XRD and for oxygen isotope composition. Whitney \& Northrop concluded that the formation of randomly ordered illite/smectite was accompanied by incomplete isotopic resetting and could be considered a transformation reaction, whereas the formation of ordered illite/smectite was accompanied by complete isotopic resetting and could therefore be considered a neoformation reaction. They found, however, that the "illite" layers reexpanded after $\mathrm{Na}^{+}$-saturation and were therefore to a large extent not true illite layers. Furthermore, Whitney \& Northrop stressed that, according to results of Yeh \& Savin (1977), isotopic exchange occurs increasingly with increasing temperature and may have reached equilibrium above $100^{\circ} \mathrm{C}$. Thus, the isotopic resetting of the ordered illite/smectite may have been an isotopic exchange, and they concluded that the interpretation of the isotopic composition of illite/ smectite must be done cautiously.

The above mentioned investigations of the illite/smectites were all carried out by XRD and chemical analysis supplemented in one case (Eslinger et al. 1979) by Mössbauer spectroscopy. Nadeau, Wilson, McHardy \& Tait (1985) investigated the conversion of smectite to illite during diagenesis in bentonite and sandstone samples by $\mathrm{XRD}$ and transmission electron microscopy (TEM) on dispersed clay particles. The neoformation mechanism, which previously had been agreed to for sandstone illites and substantiated by scanning electron microscopy (SEM), was extended to include bentonites by: Nadeau et al. (1985). They considered the particle thickness distributions observed by TEM to arise from dissolution of smectite particles and neoformation and growth of thin (from $10 \AA$ to more than $50 \AA$ thick) illite particles. The IS ordered illite/smectites were explained to be $20 \AA$ thick illite particles, with an interparticle space of $7 \AA$ (when glycolated), which by the interparticle diffraction effect should give $(10 \AA+10 \AA+7 \AA)$ regular d(001) spacings. Nadeau \& Bain (1986) investigated smectites from Cretaceous bentonites and illitic clays from Cretaceous, Devonian and Ordovician bentonites and from Jurassic and Permian sandstones. Nadeau \& Bain used XRD, chemical analysis (including infrared spectroscopy (IR)) and TEM on dispersed clay particles. The negative octahedral charges were $0.2-0.4$ in the smectites and in some of the Cretaceous illitic clays but smaller than 0.12 in the other illitic clays. The negative tetrahedral charges were about 0.1 in the smectites and $0.4-0.8$ in the illitic 
clays. All figures were per $\mathrm{O}_{10}(\mathrm{OH})_{2}$. Four of the illitic clays from Cretaceous bentonites had a higher $\mathrm{Al}$ and a lower $\mathrm{Mg}$ content in octahedral sheets than the "parent" smectites. Nadeau \& Bain concluded that all the data suggested that the illitic clays in bentonites, like those in sandstones, are neoformed, diagenetic products. They mentioned that the expandable layers in many of the illitic clays had negative charges significantly greater than 0.6 per $\mathrm{O}_{10}(\mathrm{OH})_{2}$, i.e. charges usually found for vermiculite layers (table 1).

Srodoń, Morgan, Eslinger, Eberl \& Karlinger (1986) investigated illite/smectites from Silurian (from U.K.), from Carboniferous (from Poland), and from Cretaceous (from Montana) by XRD, chemical analysis and surface area measurements. They calculated that the R0 ordered illite/ smectites required a charge of -0.55 in the illite layers to dehydrate and fix potassium. Once about $50 \%$ of the layers had collapsed, the clay ideally was composed of $20 \AA$ thick particles. They proposed that a further decrease in expandability occurred by joining together of these 20 $\AA$ thick illite particles to form $40 \AA$ thick particles and calculated that a charge of -1.0 was required for this dehydration. They attributed this higher charge compared to the -0.55 to the polarization from adjacent illitic substituted tetrahedral sheets in the same unit. They concluded therefore that the smectite to illite reaction in their samples proceeded as a transformation, in agreement with their finding that the octahedral charge was stable throughout the mixed layer series.

Ahn \& Peacor (1986a) investigated samples from the Tertiary Gulf Coast clays by HRTEM on intact bulk rock. These samples had been investigated chemically and by XRD by Hower et al. (1976). Ahn \& Peacor did not find the very thin illite particles predicted by the neoformation theory of Nadeau et al. but deduced that smectite crystals were dissolved and that illite crystals (packets) grew both laterally and in thickness (along $\mathrm{c}^{*}$ ). They did not detect mixed-layering of illite and smectite. They also investigated (Ahn \& Peacor 1986b) a standard Clay Minerals Society rectorite. Grains of this rectorite had a $20 \AA$ contrast in lattice images in HRTEM. Some of the packets seen in ground rectorite were very thick and others only $20 \AA$ thick. Ahn \& Peacor concluded that grinding and dispersion of clays prior to XRD investigation might have caused disrupture of illite/smectite and thereby resulted in the very thin particles seen in TEM by Nadeau et al. These thin particles are accordingly not present in intact bulk rock.

Altaner et al. (1988) used XRD and ${ }^{29} \mathrm{Si}$ NMR to investigate samples of illite/smectite with 90 $100 \%$ illite layers and one rectorite with $50 \%$ illite layers. The percentage of smectite layers as calculated from the ${ }^{29} \mathrm{Si}$ NMR was significantly higher than the percentage obtained by XRD (the percentages given above). They concluded that tetrahedral sheets with a low degree of $\mathrm{Al}$ for Si substitution, the smectitic substitution pattern, must be present in the illite particles and that these particles therefore had probably formed by a transformation process by $\mathrm{Al}$ for Si substitution, as proposed by Hower et al. (1976), and not by a neoformation and growth of fundamental particles, as proposed by Nadeau et al. (1985).

The solid-state transformation proposed by Pollard (1971) and Hower et al. (1976) from investigations of shales was thus substantiated by the hydrothermal experiments of Eberl \& Hower $(1976,1977)$. The solid-state transformation was opposed by Nadeau and co-workers in their theories of interparticle diffraction and of illite particle neoformation, through a smectite dissolution followed by illite precipitation and growth of very thin illite particles. They assumed that the thin particles seen in dispersed illite/smectite are present in intact bulk rock and that the illite/smectite diffraction patterns represented structures formed during specimen preparation. The solidstate transformation was also opposed by Ahn \& Peacor in their theory of dissolution of smectite layers and growth of thick illite particles. However, the chemical calculations of Srodon et al. and Altaner et al. and the observations of $\mathrm{Na}$ deau \& Bain indicate that variation in charge is present among the smectite layers seen in XRD or among the terminating layers of the fundamental particles seen in TEM of dispersed clay specimens. A neoformation of illite should result in particles where all layers have an illitic charge. Thus, these findings of different charges in the smectitic layers can best be considered to result from a solid state transformation. 


\section{Chemical controls}

The above mentioned investigations have shown that the formation of illite layers from smectite layers requires an input of an interlayer cation for fixation. It has hitherto been believed that this cation in burial diagenesis was predominantly $\mathrm{K}^{+}$. It also requires a supply of $\mathrm{Al}$ and a release of Si to increase tetrahedral substitution, and perhaps a supply of $\mathrm{Al}$ and a release of $\mathrm{Fe}$ and $\mathrm{Mg}$ to modify the octahedral sheet. The chemistry of migrating solutions can control clay diagenesis (kaolinite or illite formation) in sandstones (Millot 1970; Hancock \& Taylor 1978) and in pores and microfractures in the claystone formations investigated here (Lindgreen 1985, 1987a). The mineralogy of the pores and veins in Upper Jurassic claystones from the North Sea (Lindgreen 1985, 1987a) showed that there has been at least two phases of fluid migration from these claystone oil source rocks. In the following it is discussed to what extent claystones are open or closed systems, and to what extent illite/smectite diagenesis in claystones is influenced by pore water composition and bulk rock composition.

Lai \& Mortland (1960) showed that ions can diffuse rapidly through mud without water movement and proposed that self-diffusion of cations in a clay-water system occurred by cations jumping from the exchange site on one particle to a site on another particle. Hanshaw (1964) demonstrated for compacted montmorillonite that ion mobility is more important than ion charge for ion exchange in compacted clays and that the more mobile monovalent cations are therefore adsorbed in preference to the divalent cations.

Powers (1959) emphasized the role of chemical composition of interstitial water in clay diagenesis, especially the $\mathrm{Mg} / \mathrm{K}$ ratio, and proposed a model according to which preferential adsorption of $\mathrm{Mg}$ to $\mathrm{K}$ should decrease with depth in marine sediments due to decreasing amounts of $\mathrm{Mg}$, from the 5:1 ratio found in sea water.

Long \& Neglia (1968) investigated the content of $\mathrm{K}^{+}, \mathrm{Na}^{+}$, and $\mathrm{Cl}^{-}$in clay pore waters of Tertiary (from Italy), Triassic (from Tunisia) and Carboniferous (from the North Sea) age and the diagenesis of clay minerals in these samples. They found that the content of $\mathrm{K}^{+}$increased from $9-13 \%$ to $18-22 \mathrm{meq} \%$ (as $100 \mathrm{~K}^{+} /\left(\mathrm{CEC}+\mathrm{Cl}^{-}\right.$) at the same depth where illite/smectite changed from randomly ordered to ordered in the Italian Miocene clays. They explained this increase in $\mathrm{K}^{+}$to be due to an invasion of the claystones by alkaline fluids rich in potassium. They concluded that the pore waters were in chemical equilibrium with the minerals and that the increase in $\mathrm{K}^{+}$had resulted in formation of the ordered illite/smectite from the randomly ordered illite/smectite. In the Triassic clays they found montmorillonite at shallow depth, changing to randomly ordered mixed-layers, further to ordered mixed-layers, and finally to illite, with increasing depth, and they explained this similarly to be due to the increase in amount of $\mathrm{K}^{+}$in pore waters with depth.

Dunoyer de Segonzac (1970) estimated that the transformation of montmorillonite is mainly influenced by depth of burial because he believed in the role of pressure in the dehydration process, but he stressed the importance of the chemical composition of the interstitial solutions. Weaver \& Beck (1971) found in a Gulf Coast well in Eocene Pliocene strata that $\mathrm{Na}^{+}$was the major cation in the interstitial water $(>90 \%$ of the cations) and $\mathrm{K}^{+}$was second in abundance, followed by $\mathrm{Mg}^{2+}$ and $\mathrm{Ca}^{2+}$. The cation ratios in the well were approximately constant to $12000^{\prime}$ depth, where $\mathrm{Ca}^{2+} / \mathrm{Na}^{+}$decreased and $\mathrm{K}^{+} / \mathrm{Na}^{+}$ and $\mathrm{Mg}^{2+} / \mathrm{Na}^{+}$increased. $\mathrm{HCO}_{3}{ }^{-}$was the dominant anion, $\mathrm{SO}_{4}{ }^{2-}$ next in abundance, and $\mathrm{Cl}^{-}$ present in lower amounts. They deduced the existence of a permeability seal causing high water pressures at about $9800^{\prime}$, and proposed that the upward migration was therefore hindered, mainly for water and $\mathrm{Cl}^{-}$and to a lesser extent for the other ions. In the deeper samples, they found that $\mathrm{K}^{+}$and $\mathrm{Mg}^{2+}$ increased in the interstitial water with increasing depth and temperature and attributed this to the increased solubility of the silicate minerals at high temperature. They proposed from the chemical data that $\mathrm{K}^{+}, \mathrm{Mg}^{2+}$ and $\mathrm{Fe}$ migrated upwards to react with $\mathrm{K}^{+}$, $\mathrm{Mg}^{2+}$, and $\mathrm{Fe}$ - deficient clays to form an illitechlorite suite and that deeply buried shales are accordingly "autocannibalistic".

Schmidt (1973) investigated sidewall cores from Oligocene shales from the US Gulf Coast. $\mathrm{He}$ found that the content of $\mathrm{Na}^{+}, \mathrm{K}^{+}, \mathrm{Ca}^{2+}$ and $\mathrm{Cl}^{-}$increased downwards, whereas the content of $\mathrm{Mg}^{2+}$ did not vary with depth and he proposed that the increase in $\mathrm{K}^{+}$was caused by feldspar 
dissolution. In the interstitial water of abnormally pressured clays, the $\mathrm{Ca}^{2+}$ concentration was low and the $\mathrm{Mg}^{2+}$ concentration high. He found that $\mathrm{SO}_{4}{ }^{2-}$ increased in concentration with depth and dominated over $\mathrm{HCO}_{3}{ }^{-}$and $\mathrm{Cl}^{-}$. Furthermore he found a large difference in composition between water in the clays and in adjacent sandstones, in that the water in the sandstones was notably low in sulfate and bicarbonate. $\mathrm{He}$ found that, shallower than $10000^{\prime}$, the water in the sandstones had a concentration of dissolved solids of more than $150000 \mathrm{mg} / \mathrm{l}$, whereas deeper sandstones had a concentration of only 20000 $\mathrm{mg} / \mathrm{l}$ in wells with abnormally high pressure but increased up to $180000 \mathrm{mg} / \mathrm{l}$ in normally pressured wells. The total dissolved solids in the interstitial water of normally pressured shales increased gradually with depth, ranging between 10000 and $70000 \mathrm{mg} / \mathrm{l}$. In the zone with high pressures, the salinity of the interstitial water was about the same in the shales and in the sandstones. Schmidt concluded that the data seemed to support a selective membrane-filtration process in the shales. Furthermore, that a diagenetic release of interlayer water from smectite layers could explain the low salinities of the interstitial water in the sandstones and shales in the zone with high pressures. In the zones with normal pressure, Schmidt's finding of higher salinities in the sandstone waters than in the shale interstitial water is surprising, since membrane filtration effects of the shale should concentrate ions in the shale interstitial water. Heling \& Teichmüller (1974) found, from investigations in the Tertiary of Oberrheingraben in three wells, an unexpectedly high amount of illite layers in mixed-layers relative to temperature and thought it was due to the influence of high-saline thermal solutions probably with a high content of $\mathrm{K}$. They noted that the diffusion of $\mathrm{K}^{+}$ions into the interlayers of smectite is dependent on temperature, time and $\mathrm{K}^{+}$- concentration gradients. Hower et al. (1976) proposed that the $\mathrm{K}^{+}$for illite layer formation originated from dissolution of feldspar or detrital mica in the rock. Eberl \& Hower (1976) found that kaolinite and quartz were additionally formed during formation of illite/smectite from $\mathrm{K}^{+}$- saturated smectite in hydrothermal experiments, because $\mathrm{Al}$ and $\mathrm{K}$ for illite layer formation had to be supplied from breakdown of some smectite layers. They proposed, however, that excess $\mathrm{Al}$ and $\mathrm{K}$ in natural systems could result in the reaction:

$\mathrm{Al}^{3+}+\mathrm{K}^{+}+$smectite $\rightarrow$ illite/smectite $+\mathrm{SiO}_{2}$

Eberl \& Hower (1977) concluded from hydrothermal experiments between $260^{\circ}$ and $490^{\circ} \mathrm{C}$ that sodium saturated smectite must develop a full mica charge of -1.0 equivalents per $\mathrm{O}_{10}(\mathrm{OH})_{2}$ to form a non-expanding layer, whereas potassium smectite needs only to develop an illite charge of -0.8 equivalents per $\mathrm{O}_{10}(\mathrm{OH})_{2}$. Thus, the formation of paragonite from sodium smectite yielded more kaolinite than did the formation of illite from potassium smectite. Eberl \& Hower (1977) found that the rate-limiting control in formation of illite from smectite is tetrahedral $\mathrm{Al}$ for $\mathrm{Si}$ substitution. They reasoned that the greater negative charge developed during transformation of sodium saturated smectite is necessary for sodium dehydration prior to its fixation. Eberl (1978a) concluded from hydrothermal experiments at $300^{\circ} \mathrm{C}$ and $400^{\circ} \mathrm{C}$ that alkali saturated clays reacted by means of a gradual transformation of smectite into mixed layer clay, and that alkaline earth cation saturated clay led to a reaction in which the smectite disappeared and a rectorite-like phase emerged fully formed. Eberl (1978b) investigated the following reaction series for dioctahedral smectites by hydrothermal experiments at $300^{\circ} \mathrm{C}$ and $500^{\circ} \mathrm{C}$, with variable interlayer and solution chemistry:

1) gel $\rightarrow$ K-beidellite $\rightarrow$ random illite/smectite $\rightarrow$ K-rectorite $\rightarrow$ illite

2) K-montmorillonite $\rightarrow \mathrm{K}$-rectorite $\rightarrow$ illite

3) Na-montmorillonite or beidellite $\rightarrow$ Na-rectorite $\rightarrow$ paragonite

4) Li-montmorillonite $\rightarrow$ Li-tosudite $\rightarrow$ Li-rectorite $\rightarrow$ cookeite(?)

5) Mg-montmorillonite $\rightarrow$ Mg-rectorite $\rightarrow$ tosudite $\rightarrow$ sudoite(?)

6) Ca-montmorillonite $\rightarrow$ Ca-rectorite $\rightarrow$ margarite(?)

7) (at $150^{\circ} \mathrm{C}$ ) Al-Ca-montmorillonite $\rightarrow$ kaolinite/smectite $\rightarrow$ kaolinite

8) (at $320^{\circ} \mathrm{C}$ ) Al-Ca-montmorillonite $\rightarrow$ pyrophyllite/smectite $\rightarrow$ pyrophyllite

Heling $(1978,1979)$ believed potassium supply from external sources to be unlikely "because of 
the very low permeability of compacted shales" (Heling 1978, p.219, 1.8), and favoured K-feldspar as the potassium source because he could not believe in the simultaneous decomposition of muscovite and formation of illite. He wrote that as increasing pressure decreased pore radii and thereby lowered diffusion rates, the pressure factor in depth of burial should decrease illite formation rates. Srodon (1979) found from the Silesian coal basin that illite/smectite in pyroclastics are always more smectitic than in surrounding shales, at least by $10 \%$, and that the illite content in pyroclastics decreases more, even down to pure smectite, towards the centres of the beds. This kind of variation within a bed is, according to Srodoń who cites pers.com. with Hower and with Brusewitz, a general phenomenon; it is thought by Srodon and Hower to be due to deficiency of $\mathrm{K}$ within bentonite beds. Srodoń proposed a triple control (of temperature, K-supply and starting material) on the formation of illite/smectite and concluded that clay diagenesis proceeds more slowly than the coalification process and that the increase of illite content of illite/smectite is much faster for the IS than for the ISII structure. Lahann \& Roberson (1980) found in hydrothermal experiments that an increasing concentration of $\mathrm{K}^{+}$accelerated $\mathrm{Si}$ removal. They inferred that most of the silica dissolution and transport occurred in the interlayer space and proposed that, because of the greater hydration energies of $\mathrm{Mg}^{2+}, \mathrm{Ca}^{2+}$ and $\mathrm{Na}^{+}$relatively to $\mathrm{K}^{+}$, the movement of silica through the interlayer space was restricted by $\mathrm{Mg}^{2+}, \mathrm{Ca}^{2+}$ and $\mathrm{Na}^{+}$in the interlayer space. They wrote that this role of $\mathrm{K}^{+}$in clay diagenesis implied the importance of pore water chemistry. Roberson and Lahann (1981) wrote that no external source was required for increased tetrahedral $\mathrm{Al}$ and concluded that the $\mathrm{Al}$, which became incorporated in tetrahedral sheets in illite/smectite in hydrothermal experiments, was derived from breakdown of other smectite layers. They also showed that rates of illite formation were significantly lower when $\mathrm{Na}^{+}, \mathrm{Ca}^{2+}$ or $\mathrm{Mg}^{2+}$ were present in addition to $\mathrm{K}^{+}$ compared to when $\mathrm{K}^{+}$was present alone. They wrote that the presence of these ions is probably the main cause for slower kinetics in natural systems. Petukhov, Zvereva \& Tikhomirova (1981) found indications in Caspian oil fields that hydrocarbons have a protective effect on clay minerals and may result in "montmorillonite caps" over hydrocarbon pools. They also proposed that acidification of pore water through catalytic breakdown of hydrocarbons (producing $\mathrm{CO}_{2}$ ) on clay mineral surfaces might result in reversal of the illitization process in caprocks. Eslinger \& Sellars (1981) proposed from investigations on the Precambrian Belt Supergroup in Idaho that $\mathrm{K}$ for the smectite to illite reaction originated from detrital $\mathrm{K}$ feldspar and that $\mathrm{K}$ can be derived from breakdown of detrital mica, when insufficient $K$ feldspar is present for the smectite to illite reaction. They suggested that illite is generally formed from smectite, which is formed during orogenic volcanism, and that much of the illite then originate from metamorphism of smectite.

Nadeau \& Reynolds (1981a) found in shales and bentonites that calcium carbonate inhibits the formation of ordered illite/smectite, particularly during the incipient stages of the reaction. The data of Inoue \& Utada (1983) suggested that the development of the hydrothermal mica/smectite zone and the progress of the conversion reaction were controlled by the cation composition of the hydrothermal solution as well as by temperature. Bruce (1984) tabulated data from Tertiary shales from three basins and concluded that the threshold temperature to initiate smectite diagenesis ranged from 71 to $150^{\circ} \mathrm{C}$, it may be retarded by lack of potassium feldspars or inhibited by calcium, sodium or magnesium, and that the reaction apparently ceased when the potassium feldspars were absent. Time and pressure were, according to Bruce, of no importance in the basins investigated. Srodon (1984) concluded that the salinity of the basin (up to extreme basins such as K-Mg salt basins) did not influence the rate of illitization of expandable clay. Smart \& Clayton (1985) found that illite/smectite in sandstones generally has a higher percentage of smectite layers than in the surrounding mudrocks although the reverse is sometimes the case. They concluded that the sand laminae acted as pathways for the migration of ions to and from the system, whereas they believed that the mudrocks with $\mathrm{K}$ feldspar and discrete illite as a $\mathrm{K}^{+}$source acted as a closed system. Velde (1985) compared results of the investigations of Hower et al. (1976), Boles \& Franks (1979) and Velde on clay mineralogical transformations in the Gulf Coast Tertiary and proposed that an isothermal transi- 
tion of smectite layers to illite layers in the investigation of Hower et al. could be due to differences in sediment chemical composition at the transition position in the sediments, whereas the gradual transformation of smectite to illite layers (of Boles \& Franks) should be due to a chemical control in the sediment affecting the clay composition. Velde proposed from data on the composition of chlorites that the oxidation stage of iron should be such a chemical control.

Pearson \& Small (1988) calculated for Quaternary to Triassic shales from the Viking Graben and Moray Firth that the amount of $\mathrm{K}$ feldspar in Lower Tertiary sediments with a high content of smectite would be sufficient to allow complete illitization of the smectite layers. They concluded therefore that destruction of $\mathrm{K}$ feldspar during burial (it was absent in most wells beyond $2500 \mathrm{~m}$ depth) was a major source of $\mathrm{K}$ for illitization of deeper sediments.

According to the above mentioned investigations, $\mathrm{K}^{+}$supply is the main chemical control for the formation of illite layers from smectite. Even in systems with sufficient $\mathrm{K}^{+}$available, other cations such as $\mathrm{Mg}^{2+}, \mathrm{Ca}^{2+}$ and $\mathrm{Na}^{+}$may inhibit $\mathrm{K}^{+}$ fixation and illite layer formation. It has been proposed by several authors that this inhibition may be the cause for the slower reaction rates in natural systems where these cations are present in significant amounts. It was calculated from hydrothermal investigations that the rate limiting step in illite layer formation is tetrahedral $\mathrm{Al}$ for $\mathrm{Si}$ substitution. Therefore, the formation of the negative charge by $\mathrm{Al}$ for $\mathrm{Si}$ substitution is not necessarily inhibited by $\mathrm{Mg}^{2+}, \mathrm{Ca}^{2+}$ or $\mathrm{Na}^{+}$. This may be the cause in formation of high-charge expandable layers during diagenesis.

The investigations give examples of $\mathrm{K}^{+}$supply from pore water, from breakdown of $\mathrm{K}$ feldspar or from breakdown of detrital mica. However, the last possibility was questioned by Heling who did not believe in simultaneous decomposition of muscovite and formation of illite.

The oxidation state of iron may, according to Velde, be another chemical control. The Al required for tetrahedral substitution has been proposed by some authors to originate from dissolution of some smectite layers. It has been documented by several investigations that clays can be open systems, but also that the elements necessary for the smectite to illite layer transition can be supplied from breakdown of minerals in the clay rock. The possible role of $\mathrm{NH}_{4}{ }^{+}$as a fixed interlayer cation has not been investigated, but $\mathrm{NH}_{4}^{+}$has been found in illites by Higashi (1978) and Sterne, Reynolds \& Zantop (1982).

\section{Release of clay transformation water}

Weaver (1960) found for two Tertiary well sections and one Upper Mississippian well section in USA that log velocity values and density values increased with increasing age whereas the amount of expandable clay layers at a given depth was the same regardless of age. He suggested that the expulsion of pore water is not related to the collapse of montmorillonite as one would expect and that the contraction of expandable layers has little effect on the overall density of the sample. He noted, however, that the small amounts of water released by contraction of montmorillonite layers may be important in moving hydrocarbons from between the expanded clay layers (if formed there) to the pores.

Powers (1967) used a clay colloid chemical approach and proposed from clay mineralogical variations with depth in wells that water is expelled by compaction of marine mudrocks to about $3000^{\prime}$, except for montmorillonite clays (fig. 8). Powers applied the adsorption isotherms of van Olphen (1963) according to which moderate overburden pressure alone cannot remove the last four layers of adsorbed water from interlayer positions in montmorillonite. Powers proposed, therefore, that these last water layers are released when $\mathrm{K}$ is adsorbed and montmorillonite is transformed into illite and mixed-layers in the depth interval $6000^{\prime}$ to $10000^{\prime}$, the "no-montmorillonite level". The release of this "high-density" water may, according to Powers, create overpressuring of the source rock and flush hydrocarbons suspended in water out of the source rock through fractures and other avenues of escape. Powers calculated that only small amounts of water were released from conversion of montmorillonite layers in mixed-layers to illite, from the "no-montmorillonite level" and down to a depth of $14000^{\prime}$ in the Gulf Coast.

Burst (1969) distinguished 3 dehydration stages (fig. 8):

1. dehydration (release of pore water and excess interlayer water) 


\section{WATER ESCAPE CURVES}

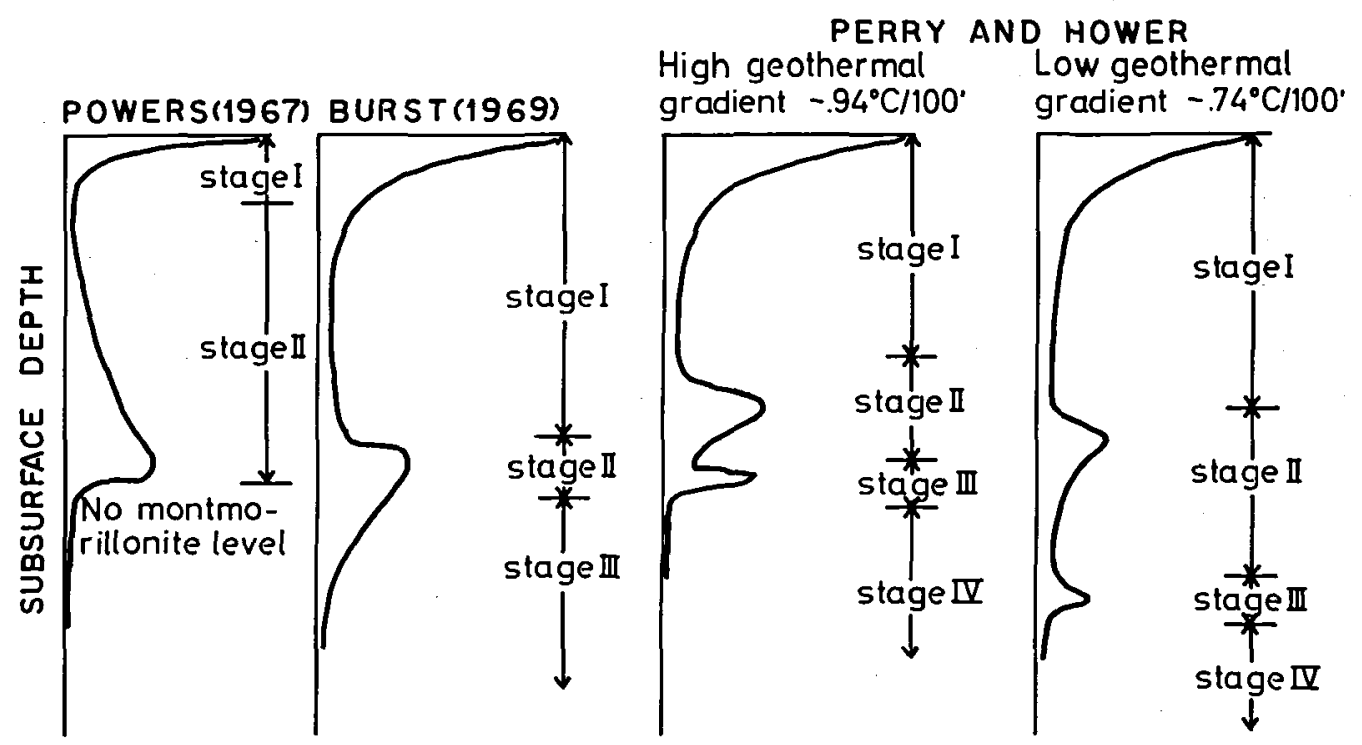

WATER AVAILABLE FOR MIGRATION

Fig. 8. Dehydration of illite/smectite in U.S. Gulf Coast sediments. The relation between burial depth and illilte/smectite dehydration as proposed by Perry \& Hower (1972), Powers (1967) and Burst (1969). After Perry \& Hower (1972, fig. 8).

2. dehydration (release of one of the two water layers between silicate layers)

3. dehydration (release of the last water layer)

He found that the hydrocarbon production depths in Gulf Coast sediments were distributed in a statistically consistent relation to the calculated second clay dehydration contour surface. Burst based his calculation of this second clay dehydration on the loss of the $17 \AA$ montmorillonite peak in glycolated specimens and on a model for conversion of montmorillonite to illite via stages with 2 and 1 water layers.

Perry \& Hower (1972) calculated the water release from the amount of montmorillonite layers in the samples (they based their calculations on the presence of two water layers in montmorillonite as determined by the adsorption isotherms of van Olphen (1963)) and proposed 4 stages as follows (fig. 8):

Stage 1: The removal through pressure of interstitial water and of interlayer water in excess of two water layers.

Stage 2: Random collapse of montmorillonite layers until c. $65 \%$ montmorillonite lay- ers have collapsed via chemical conversion to illite layers. Stage 2 was initiated in Gulf Coast shales at about $75 \%$ smectite. This stage began with a very high dehydration rate corresponding to an initially rapid decrease in the amount of smectite layers, which then decreased.

Stage 3: Transition from random to ordered interlayering. Perry and Hower calculated that a second, rapid dehydration rate took place at this stage. This stage lasted until c. $80 \%$ of the layers had collapsed, and then a reduction of the reaction rate was calculated to take place.

Stage 4: Loss of last interlayer water during collapse of the last expandable layers. This was assumed by Perry \& Hower to be quite slow and was not observed in the Gulf Coast.

Heling \& Teichmüller (1974) concluded that the first dehydration step of Burst (1969) occurred in the Tertiary of the Oberrheingraben above the oil generating zone and therefore assumed it to be of 
little importance in oil migration in Oberrheingraben. But they inferred from temperature determinations that the water released during the later dehydration stages was probably released during significant oil formation and was therefore of importance in assisting oil migration.

Foscolos et al. (1976) concluded from their investigation of Tertiary to Jurassic sediments that early mesodiagenesis (table 2) coincided with the first dehydration of water from the mixed-layers (stage 2 of Perry \& Hower (1972)) and late mesodiagenesis (with $50-75 \%$ illite in mixed-layers) with the second dehydration of the mixed-layers (stage 3 of Perry \& Hower (1972)). Powell et al. (1978) calculated that only one dehydration took place during diagenesis in rocks where vermiculite in a smectite/vermiculite/illite mixed-layer was an intermediate product in the formation of illite layers from smectite layers. They believed that the second dehydration step due to the formation of illite layers from vermiculite layers was retarded because of a Ca-vermiculite component in mixed-layers, and they cited work by Kittrick which indicated that $\mathrm{Mg}$ and $\mathrm{Ca}$ vermiculites undergo the second dehydration step at around $230^{\circ} \mathrm{C}$. Foscolos \& Powell (1979) identified chlorite as a fourth component in the smectite/vermiculite/illite mixed-layers and believed it to have formed by interlayering of $\mathrm{Fe}_{2}$ $(\mathrm{OH})_{6}$ and/or $\mathrm{Al}_{2}(\mathrm{OH})_{6}$ in expandable layer silicates. Foscolos \& Powell (1979) concluded that the first clay dehydration step took place above and the second dehydration step below the main phase of oil generation in North Canadian wells because vermiculite was an intermediate product in the illite layer formation. They therefore concluded that clay dehydration water did not have a role to play in oil migration in the wells investigated.

Pearson et al. (1982) found that illitization was initiated at a depth of $2000-2500 \mathrm{~m}$ at $65-80^{\circ} \mathrm{C}$ in shales in the Viking Graben of the North Sea and proceeded via randomly interlayered minerals to a depth of $3200-3800 \mathrm{~m}$ at $100-120^{\circ} \mathrm{C}$, where a change to the IM ordered structure was seen. They concluded that clay dehydration in the Viking Graben took place in sediments which were either immature or at most early mature with respect to oil generation. The Kimmeridge clay in the wells was close to or below the level for illite/smectite ordering.
Bruce (1984) discussed the timing of the water release from claystones during diagenesis in relation to oil migration and suggested that the water released from a smectite diagenesis occurring during or after oil generation was more effective in moving thermally generated oil and gas than water released early and above the hydrocarbon generating interval. He emphasized the additional role of the released water in forming overpressured shales and in microfracturing.

The water released during diagenesis of smectite layers has so far been calculated only from the number of smectite layers transformed into illite layers. However, Davidtz \& Low (1970), Ravina \& Low (1972) and Ravina \& Low (1977) showed for different smectites that the degree of free swelling depends on the $b$-dimension, on the degree of tetrahedral rotation and on the valence of the cation. They suggested that the clay surface acts as a template for the adsorbed water molecules and therefore that the degree of free swelling depends mainly on the degree of tetrahedral substitution of $\mathrm{Al}$ for $\mathrm{Si}$. Ross \& Rich (1973) showed that the $b$-dimension of a biotite decreased after oxidation of $\mathrm{Fe}^{2+}$ and that the tetrahedral rotation decreased with replacement of K by Ca. Odom \& Low (1978) showed that the swelling of montmorillonite, at least at low water tensions, depends linearly on the fraction of layers that fully expand and that this fraction, in turn, depends linearly on the $b$-dimension of the montmorillonite, Stucki, Low, Roth \& Golden (1984) investigated the effects of iron oxidation state on clay swelling because of the decrease of the $b$-dimension with oxidation of octahedral iron. They concluded that increase in the amount of $\mathrm{Fe}^{2+}$ enhanced the relative stability of the unexpanded and/or partially expanded layers and thereby decreased the clay swelling.

The main points of the above cited literature are: Powers proposed a mechanism whereby clay dehydration aids in oil migration out of the source rock, primary oil migration. Burst demonstrated a statistical relation between clay dehydration levels and hydrocarbon production depths. Perry \& Hower revised the dehydration stages proposed by Burst and these revised dehydration stages have been used since then. Subsequent investigations have largely confirmed the statistical relation found by Burst, although exceptions are reported. This statistical relation has 


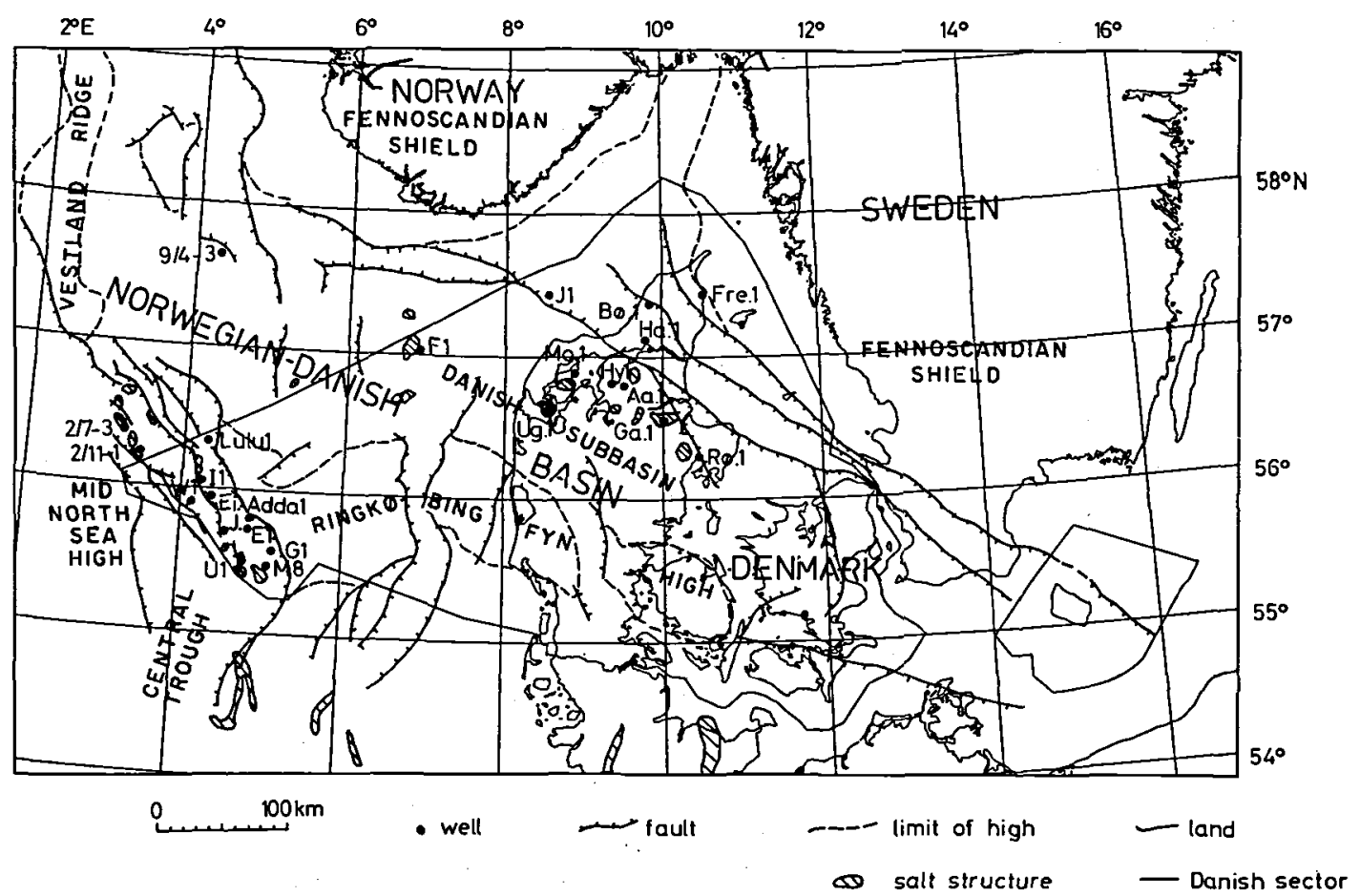

Fig. 9. Location of wells examined in the Central Trough and the Norwegian-Danish Basin. Main structural elements from Michelsen (1978) and O. V. Vejbxk (pers. com.).

Abbreviations: Bø. 1: Børglum 1; Fre. 1: Frederikshavn 1; Ga. 1: Gassum 1; Ha. 1: Haldager 1; Hy. 1: Hyllebjerg 1; Mo. 1: Mors 1; Rø. 1: Rønde 1; Ug. 1: Uglev 1; Aa. 1: Aars 1.

been interpreted to mean that clay dehydration aids in primary oil migration. But this has not been demonstrated, even if the creation of overpressures (which are often seen in oil generating clay source rocks) has been taken as a clue about the "flushing out" mechanism. As a majority of the pores in the compacted clays are very fine (Lindgreen 1987b), a "flushing out" mechanism involving Darcy flow is unlikely to play a major role in oil expulsion. The statistical relation between oil production and clay dehydration may therefore be a coincidence, so that oil maturation and expulsion on one side and illitization and clay dehydration on the other side simply occur at the same temperature. Clay dehydration was investigated from adsorption isotherms by van Olphen (1963), and his work was the basis for the clay dehydration calculations based on XRD data. The correlation between the $b$-dimension in the 2:1 layer and water adsorption on smectites appears to be important for investigation of the diagenetic clay dehydration because the fraction of smectite that fully expands depends linearly on the $b$-dimension (Odom \& Low 1978). In addi- tion, since the degree of free swelling depends mainly on the degree of tetrahedral substitution of Al for Si (Ravina \& Low 1977), the diagenetic illite layer formation by $\mathrm{Al}$ for $\mathrm{Si}$ substitution should influence the water release, even if $\mathrm{K}^{+}$is not fixed between the illitic substituted layers.

\section{Geology of the Central Trough and the Norwegian-Danish Basin}

The structural outline of the area is shown in fig. 9 and the structural outline of the Central Trough in fig. 10. The troughs in the area, the North Sea and Danish troughs, probably formed during Permo-Triassic instability of a Pangean megacontinent (Ziegler 1981). The following geological information is from Ziegler (1981). During the late Middle and Upper Jurassic, the Viking Graben and the Central Trough developed into the dominant rift system in the North Sea. During the Late Jurassic, subsidence rates in the Viking and Central grabens considerably exceeded sedimentation rates resulting in the development of 


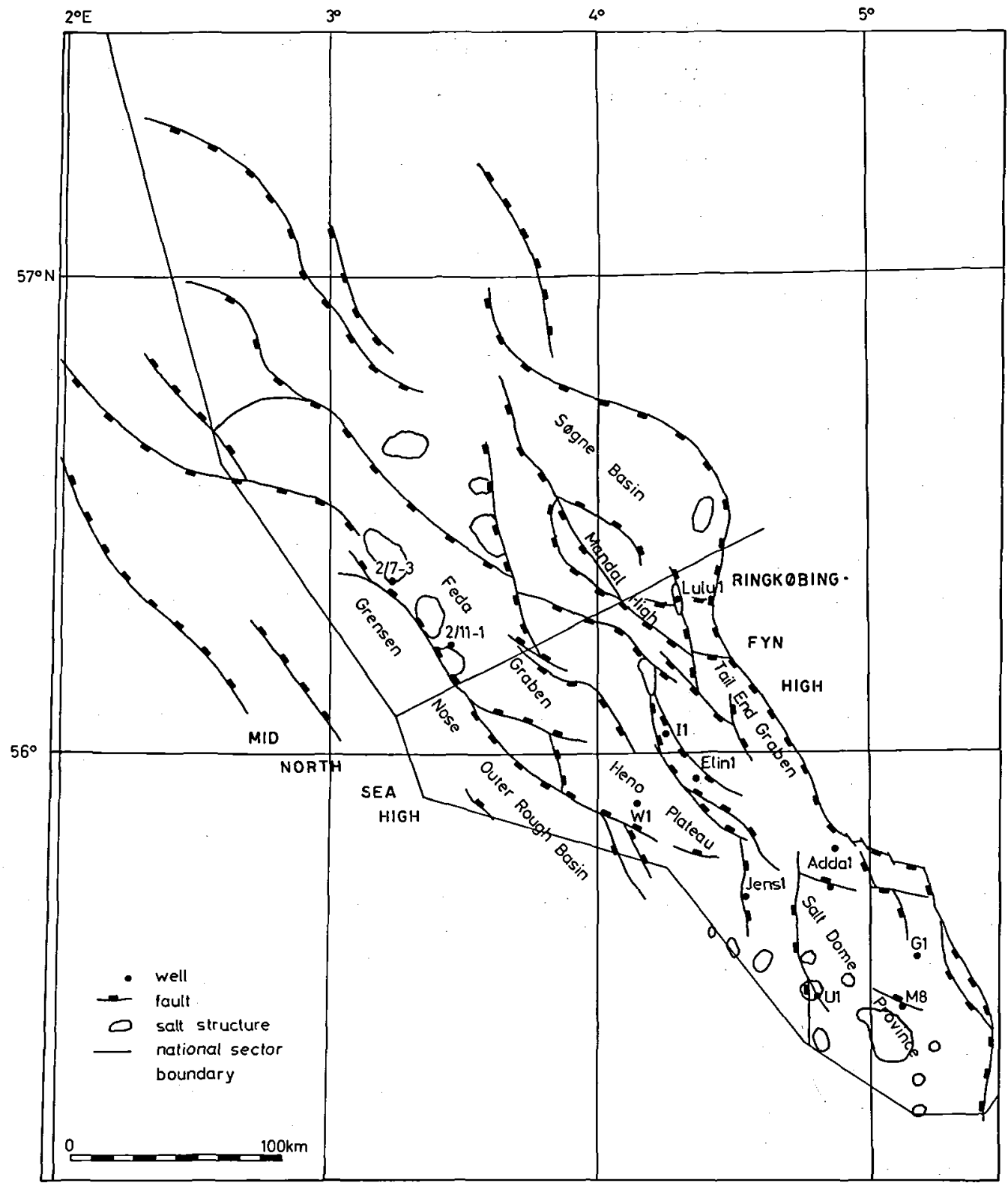

Fig. 10. Location of wells examined from the Central Trough. Main structural elements from Gowers \& Sxbøe (1985) and O. V. Vejbak (pers. com.).

deep water conditions. Upper Jurassic strata consist in these grabens of organic rich shales and local deeper water fan deposits; the Upper Jurassic strata display rapid lateral thickness variations due to the differential subsidence of individually rotated fault blocks. The highly organic Upper Jurassic shales represent the principal source rock for hydrocarbons occurring in the Central and Northern North Sea. In the Danish Trough these source rocks are, however, replaced by low-organic shales. In large parts of onshore and offshore Europe, Middle and Upper Jurassic strata were deeply eroded during Cretaceous and Tertiary times. This renders it virtually impossible to reconstruct their original thickness and to obtain an impression of the overall subsidence patterns on the basis of a regional isopach map. Moreover, isopachs of the Upper Jurassic strata 
do not reflect the true subsidence pattern in areas where sedimentation rates lagged behind subsidence rates.

During most of the Tertiary and the Mesozoic, the Fennoscandian shield and other highs were the source area for clastic sediments in the North Sea (Dypvik 1983) and in the Danish Subbasin (Michelsen 1978). Gowers \& Sæbøe (1985) took the presence of immature erosion products of early Jurassic age in 2/7-3 and in the Fulmar and Clyde fields as an indication of emergent highs (Dogger High and the Mid North Sea High) in part of Upper Jurassic. Christensen (1974) investigated the Danish Jurassic ostracod fauna and concluded that the Northwest Danish Embayment was a part of a larger North Sea Basin with ostracod faunas closely related to the faunas in English deposits.

Rawson \& Riley (1982) discussed the latest Jurassic to early Cretaceous events and the "Late Cimmerian Unconformity" in the North Sea. The transition from the Heather Formation to the Kimmeridge Clay Formation in deeper parts of the North Sea graben systems appears, according to Rawson and Riley, to mark the late Oxfordian transgression. By the early Kimmeridgian, the Kimmeridge Clay Formation and the Bream Formation organic-rich shales were accumulating over most of the offshore area with "hot" radioactive shales accumulating in parts of the Central Trough and Egersund Subbasin. In the central and northern North Sea, deposition of organicrich shales continued through the Volgian and much of the Ryazanian, and middle Volgian to early Ryazanian "hot shales" are widespread through the graben system. However, the late Cimmerian movement had, according to Rawson \& Riley, some profound effects in the offshore area though, as in the onshore region, many events were localized and not synchronous. In the basins flanking the central graben systems, regressive facies developed. In the graben systems, fault movement was renewed. Here, structural discordancy induced by step faulting and rotational slipping caused middle Volgian to Early Cretaceous sediments to transgress over a complex surface of tilted fault blocks. Rawson \& Riley interpreted the Kimmeridge Clay- Valhall boundary to represent not a regional unconformity but a major isochronous environmental change and suggested that the shales of the Kim- meridge Clay Formation were deposited under a stratified water column. They believed that these shales formed during periods of fluctuating aerobic and/or anaerobic conditions with the consequent preservation of abundant organic matter. The "hot shales" should thus result from a restriction of water circulation, coupled with minimal clastic input, due to tectonically controlled "basin enclosure". They concluded that the Kimmeridge Clay- Valhall boundary represents a flushing out of the anaerobic Kimmeridge Clay basins and a breakdown of the stratified water column as a result of the late Ryazanian transgression.

Tentative isopach maps of the Cretaceous Series (Ziegler 1981, figs. 15b and 16b) show that the sediments deposited in both the Central Trough and the Norwegian- Danish Basin attained $200-1000 \mathrm{~m}$ in Early Cretaceous and 1000 to $2000 \mathrm{~m}$ in Late Cretaceous. An isopach map of the Cenozoic series (Ziegler 1981, fig. 17) shows that about $2000 \mathrm{~m}$ of sediments were deposited in the Central Trough during Cenozoic time, but that the thicknesses of Cenozoic sediments decrease from the Central Graben eastwards through the Norwegian-Danish Basin to become about nil in the north-eastern part of Denmark.

According to Nielsen, Sørensen, Thiede \& Skarbø (1986) the subsidence of the NorwegianDanish Basin seems to have been great in Miocene and part of the Oligocene. The subsidence of the Danish Subbasin in early Palaeocene was, from the isopach maps presented by Nielsen et al., up to $200 \mathrm{~m}$ and then practically ceased. The subsidence of the Central Trough increased through Tertiary time and sediments of 1300 $3000 \mathrm{~m}$ accumulated.

Several investigations indicate that during $\mathrm{Ju}$ rassic Cretaceous there was a supply of volcanic material in addition to the detrital material supplied from the highs in the area. Jurassic volcanics (lavas and tuffaceous material) from the Forties and Piper fields were investigated by Howitt, Aston \& Jaqué (1975). They concluded that basaltic volcanism connected with rifting occurred during Jurassic times, probably commencing in the Bathonian and petering out in the Kimmeridgian. In some wells the tuffaceous material reached thicknesses of more than $120 \mathrm{~m}$, interbedded with layers of basaltic lava. Aptian and Bathonian Fuller's Earth of Southern England 
was studied by Hallam \& Sellwood (1968). Their analysis indicated it to be an almost pure montmorillonite. They concluded from the total or almost total absence of illite, kaolinite and quartz which are ubiquitous in other Mesozoic sediments that terrestial derivation of the Fuller's Earth was improbable, and that it was produced by in situ alteration of volcanic ash. Cretaceous Fuller's Earth of Southern England was studied by Cowperthwaite, Fitch, Miller, Mitchell \& Robertson (1972). They found that detrital minerals and other evidence of sedimentary transport and deposition occur in the Fuller's Earth. Moreover they believed that true bentonites of the thicknesses described by Hallam \& Sellwood (1968) could only have accumulated very close to source vents. Cowperthwaite et al. inferred from studies on the structure of Fuller's Earth that argillization of what must have been glassy volcanic ash was mainly post-depositional. The lower seam in the Cretaceous Lower Greensand deposit was, according to Cowperthwaite et al., a true ashfall, whereas the main seam was mainly ash brought in as fine, sandy material from the neighbouring land mass during a rapid transgressional episode. In discussing occurrences of Fuller's Earth of Bathonian to Aptian age, Cowperthwaite et al. suggested that volcanic episodes associated with the Jurassic to Recent rifting of the North Atlantic might have affected Southern England. They considered the English Mesozoic Fuller's Earth to be mainly montmorillonite-rich deposits derived both directly from crystal-vitric ashfalls that accumulated in small lagoons and indirectly from the rapid penecontemporaneous erosion of ashfalls covering adjacent landmasses. Knox \& Fletcher (1978) investigated samples from the Ryazanian part of the Yorkshire Speeton Clay and found four beds of volcanic clays in this formation. Jeans, Merriman, Mitchell \& Bland (1982) described Ryazanian to Albian volcanic clays from southern England and found indications for an easterly source probably in the southern North Sea area. Dixon, Fitton \& Frost (1981) found two sequences of igneous rocks of earliest Cretaceous age in well 29/25-1 at the edge of the Mid North Sea High, very close to the Auk Field. They summarized data for igneous activity in the North Sea Basin and concluded that the Jurassic phase of stretching activity in the North Sea Graben System resembles early Miocene activity in the Kenyan segment of the East African Rift, except that the erupted volumes in the North Sea are negligible by comparison with those in $\mathrm{Ke}$ nya.

Millot (1970) concluded that montmorillonite commonly results from weathering of volcanic glass, either in situ or as ash accumulated in sedimentary beds, and that this occurs only if the drainage is moderate enough to maintain an alkaline environment. Nadeau \& Reynolds (1981b) proposed from clay mineral and $\mathrm{K}$-Ar data for Cretaceous marine shales from North America that illite/smectite in these rocks originated from volcanic debris. They argued that high sedimentation rates of volcanic debris, resulting in the formation of distinct bentonite beds, means that the material has a much shorter marine residence time and is therefore essentially smectitic. Consequently, bentonite clay alteration should primarily occur below the sediment water interface, and this can explain the very low illite content of illite/smectite in bentonites.

Sedimentation of volcanic material in the North Sea region is, from the literature cited above, likely to have occurred during the period when the claystones of the present investigation were deposited. Such volcanic material will, after Millot (1970) and Nadeau \& Reynolds (1981b), form montmorillonite and illite/smectite with a high amount of smectite layers. Diagenesis of such material is likely to be different from diagenesis of illite/smectite originating from weathering.

\section{Material}

\section{Chrono- and lithostratigraphy}

Burial stage terminology is used in accordance with Jensen, Holm, Frandsen \& Michelsen (1986). Thus "the Upper Jurassic- Cretaceous boundary coincides with the boundary between the Volgian and Ryazanian or between the Lamplughi and the Runctoni ammonite zones. The base of the Volgian stage coincides with the base of the Elegans ammonite zone. The Middle- Upper Jurassic boundary is regarded as coincident with the Callovian- Oxfordian boundary" (Jensen et al. 1986, p.11, 1.13). The Kimmeridgian- Ryazanian claystones in the Danish part of the Cen- 
Table 3. Chronostratigraphy of Central Trough samples, according to Hoelstad (1986), Myhre (1977) and Ofstad (1981).

\begin{tabular}{llll}
\hline Well & Depth & Stratigraphy & Formation \\
\hline E1 & $2983 \mathrm{~m}$ & Late Ryazanian & Farsund \\
& $3444 \mathrm{~m}$ & Early Volgian & Farsund \\
& $3828 \mathrm{~m}$ & Early Volgian & Farsund \\
& $3938 \mathrm{~m}$ & Early Volgian & Farsund \\
G1 & $2609 \mathrm{~m}$ & Middle Volgian & Farsund \\
& $3441 \mathrm{~m}$ & Kimmeridgian & Farsund \\
M8 & $2368 \mathrm{~m}$ & Middle Volgian & Farsund \\
& $2387 \mathrm{~m}$ & Early Volgian & Farsund \\
& $2588 \mathrm{~m}$ & Kimmeridgian & Farsund \\
& $2725 \mathrm{~m}$ & Kimmeridgian & Farsund \\
U1 & $2542 \mathrm{~m}$ & Early Volgian & Farsund \\
& $2716 \mathrm{~m}$ & Kimmeridgian & Farsund \\
& $2899 \mathrm{~m}$ & Kimmeridgian & Farsund \\
I1 & $3371 \mathrm{~m}$ & Ryazanian & Farsund \\
& $3441 \mathrm{~m}$ & Late Volgian & Farsund \\
& $3688 \mathrm{~m}$ & (Volgian?) & Farsund \\
& $3908 \mathrm{~m}$ & (Volgian?). & Farsund \\
2/11-1 & $3633 \mathrm{~m}$ & Kimm-Early Volgian & Farsund \\
& $3877 \mathrm{~m}$ & Kimm-Early Volgian & Farsund \\
& $4548 \mathrm{~m}$ & Kimm-Early Volgian & Haugesund \\
27-3 & $3365 \mathrm{~m}$ & Late Volgian & Mandal \\
& $3502 \mathrm{~m}$ & Middle Volgian & Farsund \\
& $3789 \mathrm{~m}$ & Early Volgian & Faugesund \\
& $4178 \mathrm{~m}$ & Early Volgian? & Faugesund \\
Lulu 1 & $3420 \mathrm{~m}$ & Early Volgian & Farsund \\
W1 & $3816 \mathrm{~m}$ & Middle Volgian & Farsund \\
& $4051 \mathrm{~m}$ & Kimmeridgian & Farsund \\
& $2917 \mathrm{~m}$ & Middle Volgian & Farsund \\
& & & \\
\hline
\end{tabular}

tral Trough belong to the Farsund Formation and in the Norwegian Central Trough to the Mandal, Farsund and Haugesund Formations. The investigated Upper Jurassic claystones from the Danish Subbasin belong to the Børglum Formation which is synchronous with the oldest part of the Farsund Formation and of Kimmeridgian- Middle Volgian age (Olaf Michelsen, pers. com.; Niels Poulsen, pers. com.).

\section{Formations and samples}

Claystones during Kimmeridgian - Volgian were sedimented in a probably deeper shelf environment in the Central Trough and are here found at present with a depth to top Jurassic of 2100 to $4000 \mathrm{~m}$ (Michelsen \& Andersen 1983). In the same period, claystones were sedimented on a more shallow shelf in the Danish Subbasin and are here presently found with a depth to top Jurassic of 400 to $2400 \mathrm{~m}$ (Michelsen \& Andersen
1983 and Michelsen 1978). In the Central and Northern North Sea, deposition of organic-rich shales continued through the Volgian and much of the Ryazanian, and Middle Volgian to Early Ryazanian "hot shales" are widespread through the graben system, but regressive facies developed in the basins flanking the central graben systems (Rawson \& Riley 1982). The claystones of Kimmeridgian- Volgian- (Lower Ryazanian) age in the Central Trough and the NorwegianDanish Basin have been selected for the present investigation. Selection of one or a few equivalent formations found over a wide range of burial depths will minimize the variability of parent material and makes it easier to reconstruct diagenetic processes. The variation in burial depth of these claystones is similar to the variation seen in the Tertiary US Gulf Coast clays and the variation in maturity of the organic material in the selected formations is from minimum oil generation to peak oil generation (Thomsen, Lindgreen \& Wrang 1983). The thicknesses of the Farsund plus Mandal formations vary widely in different wells because of differential subsidence in the Central Trough during Upper Jurassic. Very thick sections are present in the wells from the Tail End Graben and the Feda Graben (Michelsen, Frandsen, Holm, Jensen, Møller \& Vejbæk 1986). Jensen et al. (1986) proposed that these thick sections may be explained by redeposition into deeper parts of the basin and Myhre (1977) proposed that the thick sequence in $2 / 11-1$ may be partly due to repeated sections in a fault zone. According to Michelsen et al. (1986), salt movements in wells M8, U1 and Lulu 1 may have been responsible for the deposition of relatively thin Farsund Formation sequences in these wells and for the absence of Volgian to Ryazanian sediments in $U 1$ because of non-deposition. The variation in the thicknesses of the Børglum Formation in the Danish Subbasin and of the combined, equivalent Sauda and Tau formations in 9/4-3 are mainly due to the development of regressive, sandy or silty facies during Volgian and Ryazanian. Relatively thick sections in the Danish Subbasin are found in the wells in the centre of the basin (in Aars $165 \mathrm{~m}$ ), but the member is very thin or absent in wells at the margin of the basin, e.g. $4 \mathrm{~m}$ in Skagen 1, because of the regression.

The lithostratigraphical units of Vollset \& Doré (1984) and Jensen et al. (1986) have been 
used. From the Central Trough, material was selected from the Haugesund Formation in wells $2 / 7-3$ and $2 / 11-1$, from the Farsund Formation in wells Adda 1, E1, G1, I1, Lulu 1, M8, W1, 2/7-3 and $2 / 11-1$, and from the Mandal Formation in $2 / 7-3$. The Haugesund Formation is of Kimmeridgian age in wells 2/7-3 and 2/11-1 (Ofstad 1981 and Myhre 1977), the Farsund Formation is of Kimmeridgian-Ryazanian age in wells Adda 1 , E1, G1, I1, Lulu 1, M8, W1, 2/7-3 and 2/11-1 (Jensen et al. 1986 and Birkelund, Clausen, Hansen \& Holm 1983) and the Mandal Formation is of Portlandian-Ryazanian age in 2/7-3 (Ofstad 1981). Chronostratigraphy of the samples is shown in table 3.

Two conventional cores from the Farsund Formation were available for sampling, one from E1 and one from 2/11-1. The amounts of side-wall core material available were too small for clay mineralogical analysis. The other samples are from drill cuttings. They represent large intervals, 30 feet in M8 and in G1 (2609 m), 20 feet in $\mathrm{E} 1$ and 10 feet in the other wells in the Central Trough. In the cutting samples, lithologies of the depth interval in question are mixed and thus give an average value for the interval. A drawback is that errors in depth may occur because the rate of circulation of the drilling mud (which brings up the cuttings) may differ from the calculated value. Caving may occur in non-cased parts of the hole and caving from other formations may then mix with the sample material. Unconsolidated and/or highly smectitic clays may disintegrate during the drilling and be mixed with the drilling mud. Prior to analysis, the cuttings material was cleaned of drilling mud by soaking and washing in distilled water. After drying, the dominating rock type (dark grey from the Haugesund Formation in $2 / 7-3$ and $2 / 11-1$, dark grey from the Farsund Formation, and dark grey from the Mandal Formation in 2/7-3) was hand-picked for analysis.

In the Norwegian-Danish Basin, conventional cores were available from the Børglum Formation in the wells Børglum 1, Frederikshavn 1, Gassum 1 and Haldager 1, and from the Bream Formation in Uglev 1. Cuttings were available from the Børglum Formation in Aars 1, F1, Hyllebjerg 1, Mors 1 and Rønde 1 and from the Sauda and Tau Formations in 9/4-3. The cuttings intervals are 30 feet except in Rønde 1 and Aars 1
(15 feet), and Hyllebjerg 1 (10 feet). The cuttings material from the Norwegian- Danish Basin wells was also washed and the dark grey cuttings handpicked for analysis.

The depth figures given for the samples are depth in $\mathbf{m}$ below kelly bushing. The depth figures for cuttings samples are the bottom figures of the interval given by the drilling company.

\section{Preparation procedures}

The mixed-layer illite/smectite should be separated from the other minerals in the sample prior to XRD and chemical analysis, so that the interference from other minerals is minimized. This separation is difficult in well-compacted, highly organic claystone where the mineral particles are aggregated by organic matter. Hower et al. (1976) wrote that the coarse clay fractions in the deeper burial diagenetic samples from the Oligocene-Miocene Gulf Coast contained a significant amount of clay, mainly mixed-layer illite/smectite, that could not be separated (their max. depth was $5500 \mathrm{~m}$ ). Except for the specimens for HRTEM, the samples in the present investigation were therefore given a combination of ultrasonic and chemical pretreatment prior to analysis. The $\mathrm{NaOCl}$ procedure of Anderson (1963) was applied to destroy the fairly large amount of organic matter in the claystones. Removal of the organic matter aids in particle dispersion and destruction of possible clay interlayered organic matter (indicated to be present by gas adsorption experiments on these clays (Lindgreen 1987b)). Interlayered organic matter may furthermore prevent the characteristic swelling of smectite layers following cation exchange and glycol/glycerol intercalation. The $\mathrm{NaOCl}$ treatment was continued until the reaction ceased (sometimes simultaneously with the appearance of a violet colour from $\mathrm{MnO}_{4}^{-}$). In most cases 4 to 5 treatments, each lasting $15 \mathrm{~min}$, were sufficient, but the treatment had to be repeated up to 10 times with samples containing large amounts of organic matter.

The dithionite-citrate procedure of Mehra \& Jackson (1960) was then used for removal of iron and aluminium oxides and hydroxides. The reddish colour of the core sample Gassum 1, 1191.2 $\mathrm{m}$, showed that iron oxides were present in this sample. In most of the other samples, especially 
those from the Central Trough, $\mathrm{Fe}^{2+}$ in pyrite in the samples was oxidized during the $\mathrm{NaOCl}$ treatment and formed reddish iron oxides-hydroxides at the high $\mathrm{pH}(9.0)$ used during this treatment. The aggregating role of the iron and aluminium oxides made their removal an important step in the disaggregation procedure. The solution/sample ratio was about 5 in both the $\mathrm{NaOCl}$ procedure and the dithionite-citrate procedure. Dithionite was added in portions of $100 \mathrm{mg}$ per $\mathrm{g}$ sample until the reddish colour of the sample had changed to greyish-bluish. One treatment with dithionite-citrate, lasting $15 \mathrm{~min}$., was sufficient for most samples, but two treatments were necessary to reduce the iron oxides in samples from the Central Trough with large amounts of organic matter and pyrite.

To check a possible breakdown of clay minerals during the treatment, $\mathrm{Al}_{2} \mathrm{O}_{3}, \mathrm{SiO}_{2}, \mathrm{Fe}_{2} \mathrm{O}_{3}$ and $\mathrm{K}_{2} \mathrm{O}$ dissolved during the $\mathrm{NaOCl}$ and dithionitecitrate treatments were measured by atomic absorption spectrometry for some of the samples. The $\mathrm{NaOCl}$ treatment dissolved less than: $0.3 \%$ $\mathrm{K}_{2} \mathrm{O}, 0.02 \% \mathrm{Fe}_{2} \mathrm{O}_{3}, 0.01 \% \mathrm{Al}_{2} \mathrm{O}_{3}$ and less than $0.2 \% \mathrm{SiO}_{2}$. The dithionite citrate treatment dissolved less than: $0.02 \% \mathrm{~K}_{2} \mathrm{O}, 0.2 \% \mathrm{SiO}_{2}$ and less than $0.05 \% \mathrm{Al}_{2} \mathrm{O}_{3}$ and from 0.2 to $3.3 \% \mathrm{Fe}_{2} \mathrm{O}_{3}$. This $\mathrm{Fe}_{2} \mathrm{O}_{3}$ was probably due to pyrite and iron carbonates in the samples. The clay minerals therefore seem stable to the chemical treatments, in accordance with pretreatment experiments on soil clays by Follett, McHardy, Mitchell \& Smith (1965) and on a microcrystalline soil clay by Lindgreen \& Rasmussen (1978). A Palaeozoic glauconite from Sweden and a Clay Minerals Society ripidolite were subjected to the treatments and Mössbauer spectroscopy showed that their $\mathrm{Fe}^{3+} / \mathrm{Fe}^{2+}$ ratios were not changed by the treatment. Furthermore, less than $0.01 \% \mathrm{Al}_{2} \mathrm{O}_{3}$, $0.01 \% \mathrm{Fe}_{2} \mathrm{O}_{3}$ and $0.2 \% \mathrm{SiO}_{2}$ were dissolved from the ripidolite by $\mathrm{NaOCl}$ and $0.1 \% \mathrm{Fe}_{2} \mathrm{O}_{3}, 0.7 \%$ $\mathrm{Al}_{2} \mathrm{O}_{3}$ and $0.4 \% \mathrm{SiO}_{2}$ by the dithionite citrate treatment. It may therefore be deduced that the treatments as described above have minimal effect on the structural elements of the clay minerals of the samples. However, even the combination of chemical and ultrosonic dispersion could not disaggregate the samples totally, as optical microscopy showed that clay aggregates were present in the sand- and silt fraction (H. Micheelsen, pers. com.).
The chemically and ultrasonically treated samples were divided into sand plus silt and into clay by centrifugation or elutriation. Thereafter, the coarse $(2-0.2 \mu \mathrm{m})$ and fine clay $(<0.2 \mu \mathrm{m})$ fractions were separated in a continuous flow centrifuge. As $10 \AA$ and $5 \AA$ XRD reflections from discrete illite were present in the fine clay fraction, and as discrete illite makes a detailed XRD and chemical mixed layer investigation difficult, the fine clay fraction was subdivided into the mixed-layer fraction and a fraction dominated by discrete illite and/or kaolinite by the ethanol procedure, as described by Hansen \& Lindgreen (1989).

\section{Investigation of discrete clay minerals and non-clay minerals}

$\mathrm{Mg}^{2+}$ - saturated and air-dried or glycolated specimens and $\mathrm{K}^{+}$- saturated and heated (to $250^{\circ} \mathrm{C}$ ) specimens were analysed from the fine $(<0.2$ $\mu \mathrm{m})$ fraction dominated by discrete clay minerals: $\mathrm{Mg}^{2+}$ - saturated, air-dried or glycerolated specimens, and $\mathrm{K}^{+}$- saturated, heated (to $250^{\circ} \mathrm{C}$ ) specimens were analysed from the coarse clay fraction. Reflection areas (in \% of the total peak area of (001) reflections in the diffractogram of the $\mathrm{K}^{+}$-saturated specimen heated to $250^{\circ} \mathrm{C}$ ) were calculated as follows: The illite/kaolinite area ratio was calculated from the diffractogram of the $\mathrm{Mg}^{2+}$-saturated, glycerolated specimen. The relative areas for kaolinite, for illite+vermiculite+smectite+illite/smectite; and for chlorite were then calculated from the diffractogram of the $\mathrm{K}^{+}$-saturated specimen heated to $250^{\circ} \mathrm{C}$. The ratio between areas of vermiculite and kaolinite was calculated from the diffractogram of the $\mathrm{Mg}^{2+}$-saturated, glycerolated specimen, taking into account the contribution of chlorite to the 14 $\AA$ peak in this diffractogram. The (area) ratios:

(mixed-layer illite/smectite)/kaolinite and smectite/kaolinite were then calculated from the diffractogram of the $\mathrm{Mg}^{2+}$-saturated, air-dried specimen, taking into account the contribution of chlorite and vermiculite to the $14 \AA$ peak in this diffractogram. Results are given in table $6 a$ and b.

$\mathrm{Na}^{+}$- saturated, randomly oriented specimens were prepared from the fine $(<0.2 \mu \mathrm{m})$ clay fraction dominated by discrete clay minerals and 
from the coarse clay fraction for investigation of possible (hkl) reflections from clay minerals and the possible presence of other minerals. $\mathrm{Na}^{+}$saturated, randomly oriented specimens were prepared from the sand plus silt fraction to investigate the total mineralogy of this fraction.

\section{XRD characterization of mixed-layers}

\section{Identification of layers at group level}

The clay mineral classification was mentioned in the chapter on the structure of clay mineral layers. The negative charge of mica layers is sufficient to keep the layers together with cations, usually $\mathrm{K}^{+}$, in between, and the layer thickness is fixed at $10 \AA$. The negative layer charge of vermiculite and smectite is so low that the layers can be separated and cation exchange and sorption of organic compounds can occur in the interlamellar space. The uptake of water and organic compounds depends on the exchangeable cation. With $\mathrm{Mg}^{2+}$ as exchangeable cation, standard smectites and vermiculites form 2-layer hydrates between $52 \%$ and $79 \%$ relative humidity, i.e. the normal humidity range in the laboratory (MacEwan \& Wilson 1984, table 3.1). Two organic compounds are widely used as interlamellar sorbents for identification of smectite and vermiculite layers: ethylene glycol and glycerol. They generally give one and two layered complexes with vermiculite and smectite layers, respectively (MacEwan \& Wilson 1984). However, ethylene glycol may give two layered complexes with some vermiculites. Generally, neither high charge smectites nor vermiculites will expand with ethylene glycol when they are $\mathrm{K}^{+}$- saturated (MacEwan \& Wilson). MacEwan \& Wilson (1984) concluded that glycerol solvation of $\mathrm{Mg}^{2+}$ - saturated specimens is the best basis to distinguish empirically between vermiculites and smectites as classified in table 1 . However, the structure of the ethylene glycol interlayer complex is well established (MacEwan \& Wilson 1984), and ethylene glycol has therefore been used in computer modelling, also because ethylene glycol is more commonly used than glycerol. This may partly be due to the fact that ethylene glycol can fairly easily be introduced in interlamellar spaces of air-dried specimens if the specimens are exposed to ethylene glycol vapour at $50-60^{\circ} \mathrm{C}$ for two or more days (MacEwan \& Wilson 1984). Therefore, one specimen can be investigated air-dried and later be ethyleneglycolated and may even then be heated and investigated again, making the specimen preparation easier.

The mentioned relation between the clay mineral classification criteria (amount of layer charge) and layer thickness plus interlayer spacing makes XRD a routine method for clay mineral identification. The basal reflections originating from layer and interlayer spacings, $d(001)$, are enhanced if the clay minerals are oriented with their 001 parallel to the specimen surface. This orientation is favoured if a clay film prepared by 1) suction of a clay in suspension onto a porous, ceramic plate or 2) by smearing a thick suspension or 3) pipetting a thin suspension on a glass slide and leaving the water to evaporate. Gibbs (1965) compared these methods and found that the pipette method. resulted in marked differential sedimentation in a mixture of coarse and fine clay particles but that it gives the highest degree of preferred orientation. As the mixed layers investigated in the fine-clay fraction are microcrystalline (according to the TEM investigations from one to several elementary layers thick) the pipette method for preparation of oriented XRD specimens was used in the present investigation. They were prepared with $2.5 \mathrm{mg}$ sample per $\mathrm{cm}^{2}$. This is a very thin specimen for XRD in the range $1.5^{\circ}-30^{\circ} 2 \theta$ when compared to the amount of material required for specimens "infinitely thick" to the XRD radiation as calculated by Brown \& Brindley (1984, table 5.2). Comparison between diffractograms from the 2.5 $\mathrm{mg} / \mathrm{cm}^{2}$ specimens and diffractograms from thicker specimens showed, however, that the 2.5 $\mathrm{mg} / \mathrm{cm}^{2}$ specimens were infinitely thick to $\mathrm{Cu}-$ radiation in the range $1.5^{\circ}-30^{\circ} 2 \theta$. The use of thin specimens should minimize the effect of differential sedimentation during specimen preparation.

$\mathrm{Mg}^{2+}$ - saturated, air-dried and oriented specimens were investigated because of the stability of the two-layer water complex for both vermiculites and smectites of such specimens over a wide range of relative humidities. Smectite and vermiculite layers have therefore basal spacings $\mathrm{d}(001)$ at about $15 \AA$ and illite layers at $10 \AA$. These specimens were then glycolated at $60^{\circ} \mathrm{C}$ in 
three days and then investigated by XRD. $\mathrm{Mg}^{2+}$. saturated and glycerolated specimens were also prepared, in accordance with the applicability of this specimen type to the clay mineral classification as discussed above. These specimens were prepared by mixing two drops of $10 \%$ glycerol in water with $1 \mathrm{ml}$ of clay-water suspension and leaving this suspension to dry on the glass slide. A set of specimens were saturated with $\mathrm{K}^{+}$, air dried, and afterwards analysed by $\mathrm{CuK} \alpha$ and $\mathrm{CrK} \alpha$ radiation. These specimens were later glycolated at $60^{\circ} \mathrm{C}$ for 3 to 9 days and analysed with $\mathrm{CuK} \alpha$ radiation. The diffractograms did not change with 3 to 9 days duration of glycol treatment. Another set of specimens saturated with $\mathrm{K}^{+}$were heated to $250^{\circ} \mathrm{C}$ for one hour to dehydrate the smectite and vermiculite layers and cause a decrease of $d(001)$ for these mineral layers to about $10 \AA$. The $\mathrm{K}^{+}$saturation diminishes the possibility for rehydration after cooling (MacEwan \& Wilson 1984).

Lindgreen \& Rasmussen (1978) found that $\mathrm{Mg}^{2+}$ - saturated specimens compared to $\mathrm{Na}^{+}$- saturated specimens gave much lower reflection intensities. Therefore, $\mathrm{Na}^{+}$- saturated, oriented specimens were also prepared and examined by XRD before and after glycolation. However, the reflection intensities were about the same as for $\mathrm{Mg}^{2+}$ - saturated specimens. To obtain information about the layer charge of the expandable mixed-layer component, $\mathrm{K}^{+}$- saturated and oriented specimens were prepared and glycolated prior to XRD investigation.

Randomly oriented powder specimens were prepared of the $\mathrm{Na}^{+}$- saturated mixed-layer fractions for investigation of (hkl) reflections.

\section{Mixed-layer terminology}

The symbols and nomenclature of Reynolds (1984) are used in the following. The fraction of illite layers (I) in the illite/smectite (illite/smectite) is given by $P_{I}$, which is the probability for a given layer in the mixed-layer crystal to be an illite layer. $\mathbf{P}_{S . I}$ is the probability that an illite layer succeeds a smectite layer, $P_{S I, I}$ is the probability that an illite layer succeeds a SI unit, and $P_{\text {SII.I }}$ is the probability that an illite layer succeeds a SII unit. Ordering can be: a) random ordering or I-S segregation (which means that illite and smectite layers have a tendency to be segregated; b) IS ordering or rectorite ordering (including IS-I segregation, i.e., that IS units and I layers have a tendency to be segregated); c) ISI ordering (including ISI-I segregation); and d) ISII ordering or Kalkberg ordering. The Reichweite ordering values used by Lindgreen \& Hansen (1991) and by Lindgreen et al. (1991) were incorrect as follows: a) for random ordering or I-S segregation was used $\mathrm{R} 0$; b) for IS ordering or IS-I ordering was used R1; and c) for ISII ordering was used R3.

\section{Estimation of illite percentages and ordering}

In the following, $(00 \mathrm{a})_{\mathrm{I}} /(00 \mathrm{c})_{\mathrm{S}}$ means the composite peak from the reflections (00a) from illite layers and $(00 \mathrm{c})$ from smectite layers in mixedlayer illite/smectite. $(00 \mathrm{a})_{\mathrm{I}} /(00 \mathrm{~b})_{\mathrm{V}} /(00 \mathrm{c})_{\mathrm{S}}$ means the composite peak from the reflections (00a) from illite layers, $(00 \mathrm{~b})$ from vermiculite layers and $(00 \mathrm{c})$ from smectite layers in mixed-layer illite/vermiculite/smectite. (00d) Is means the (00d) reflection from IS ordered I/S.

For $\mathrm{Mg}^{2+}$ - saturated and glycolated specimens the degree of ordering was estimated by visual inspection of the diagrams. Random ordering or I-S segregation was assessed to be dominant, when smectite peaks at $17 \AA(001)$ and $2.83 \AA$ (006) and illite peaks at $10 \AA(001)$ and $1.98 \AA$ (005) were present. IS ordering was disclosed by peaks between $14.5 \AA(002)_{\text {IS }}$ and $10 \AA(001)_{\text {I }}$ and by the presence of a peak at $2.7 \AA(0.0 .10)_{\text {IS }}$. ISII ordering was deduced from a shoulder at about $11 \AA(004)$ and a peak at $2.6 \AA(0.0 .18)$. To start with, the percentages of illite layers were then calculated by the following methods:

a) For glycolated specimens $\left(\mathrm{Mg}^{2+}\right.$ - saturated or $\mathrm{Na}^{+}$-saturated) the percentages of illite layers in the mixed layers were calculated from peak migration of $(001)_{\mathrm{I}} /(002)_{\mathrm{S}}$ and $(002)_{\mathrm{I}} /(003)_{\mathrm{S}}$ from the tables of Hower (1981a).

b) For $\mathrm{Mg}^{2+}$ - saturated, air-dried specimens the percentages of illite layers in the mixed-layers were calculated from peak migration of (001) ${ }_{\mathrm{I}} /(002)_{S}$ for random ordering or I-S segregation and of $(002)_{1 S} /(001)_{I}$ for IS ordering from table 3.5 of Hower (1981a).

The $P_{1}$ values for illite/smectite were then estimated from computer modelling as follows: 
Table 4a: Mixed-layer illite/smectite from wells in the Central Trough. Statistical parameters obtained from comparison between recorded and computer simulated X-ray diffraction patterns. From Lindgreen et al. (1991, table 1).

\begin{tabular}{|c|c|c|c|c|c|c|c|}
\hline \multirow{2}{*}{$\begin{array}{l}\text { Well } \\
\text { Depth, } \\
\text { meters }\end{array}$} & \multicolumn{4}{|c|}{$M g^{2+}-$ saturated specimens } & & \multicolumn{2}{|c|}{$\begin{array}{c}K^{+}-\text {saturated specimens } \\
\text { (glycolated) }\end{array}$} \\
\hline & $\mathbf{P}_{\mathbf{I}}$ & $P_{\text {S.I }}$ & $P_{\text {SI.I }}$ & $P_{\text {SII.I }}$ & & $\mathbf{P}_{\mathrm{I}}$ & $P_{\text {S.I }}$ \\
\hline \multicolumn{8}{|l|}{ E1 } \\
\hline 2983 & 0.65 & 0.45 & 0.76 & 0.76 & I-S segregated & 0.82 & 0.82 \\
\hline 3444 & 0.80 & 1.00 & 0.55 & 0.82 & IS & & \\
\hline 3828 & 0.80 & 1.00 & 0.45 & 0.85 & IS & 0.95 & 0.95 \\
\hline 3938 & 0.85 & 1.00 & 0.55 & 0.88 & IS & 0.85 & 0.85 \\
\hline \multicolumn{8}{|l|}{ G1 } \\
\hline 2609 & 0.75 & 0.65 & 0.78 & 0.78 & I-S segregated & & \\
\hline 3441 & 0.70 & \multicolumn{4}{|c|}{3 -component $(0.10 \mathrm{~V}, 0.20 \mathrm{~S})$} & 0.85 & \\
\hline \multicolumn{8}{|l|}{ M8 } \\
\hline 2368 & 0.65 & 0.55 & 0.70 & 0.71 & I-S segregated & 0.82 & 0.82 \\
\hline 2387 & 0.70 & 0.50 & 0.79 & 0.79 & I-S segregated & 0.80 & 0.70 \\
\hline 2588 & 0.75 & 0.55 & 0.82 & 0.82 & I-S segregated & 0.90 & 0.90 \\
\hline 2725 & 0.82 & 1.00 & 0.50 & 0.86 & IS & 0.90 & 0.90 \\
\hline \multicolumn{8}{|l|}{ U1 } \\
\hline 2542 & 0.70 & 0.60 & 0.74 & 0.74 & I-S segregated & 0.80 & 0.80 \\
\hline 2716 & 0.60 & 0.30 & 0.80 & 0.80 & I-S segregated & 0.80 & 0.60 \\
\hline 2899 & 0.70 & 0.60 & 0.74 & 0.74 & I-S segregated & 0.90 & 0.90 \\
\hline \multicolumn{8}{|l|}{ I1 } \\
\hline 3371 & 0.82 & 1.00 & 0.60 & 0.83 & IS & 0.90 & 0.90 \\
\hline 3441 & 0.82 & 1.00 & 0.60 & 0.83 & IS & 0.95 & 0.95 \\
\hline 3688 & 0.82 & 1.00 & 0.60 & 0.83 & IS & & \\
\hline 3908 & 0.85 & 1.00 & 0.65 & 0.86 & IS & 0.95 & 0.95 \\
\hline \multicolumn{8}{|l|}{$2 / 11-1$} \\
\hline 3633 & 0.82 & 1.00 & 0.60 & 0.83 & IS & 0.90 & 0.90 \\
\hline 3877 & 0.85 & 1.00 & 0.55 & 0.88 & IS & 0.95 & 0.95 \\
\hline 4548 & 0.85 & 1.00 & 0.65 & 0.86 & IS & 0.95 & 0.95 \\
\hline \multicolumn{8}{|l|}{$2 / 7-3$} \\
\hline 3365 & 0.40 & 0.40 & 0.40 & 0.40 & random & 0.75 & 0.75 \\
\hline 3502 & 0.40 & 0.30 & 0.55 & 0.55 & I-S segregated & & \\
\hline 3789 & 0.95 & 1.00 & 1.00 & 1.00 & ISII & 0.95 & 0.95 \\
\hline 4178 & 0.90 & 1.00 & 0.70 & 0.91 & IS & 0.95 & 0.95 \\
\hline \multicolumn{8}{|l|}{ Lulu 1} \\
\hline 3420 & 0.85 & 1.00 & 0.55 & 0.88 & IS & 0.95 & 0.95 \\
\hline \multicolumn{8}{|l|}{ W1 } \\
\hline 3816 & 0.50 & 0.40 & 0.60 & 0.60 & I-S segregated & 0.75 & 0.55 \\
\hline 4051 & 0.80 & 1.00 & 0.45 & 0.85 & IS & & 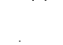 \\
\hline \multicolumn{8}{|l|}{ Adda 1} \\
\hline 2633 & 0.65 & 0.45 & 0.76 & 0.76 & I-S segregated & & \\
\hline 2917 & 0.70 & 0.50 & 0.79 & 0.79 & I-S segregated & 0.85 & 0.85 \\
\hline
\end{tabular}

The diffractograms showed that the $\mathrm{d}(001)_{S}$ was $17.0 \AA$ in glycolated specimens. In $\mathrm{Mg}^{2+}-$ saturated, air-dried specimens the $\mathrm{d}(001)$ of smectite was calculated to be $14.5 \AA$ from the (001) values of higher orders. Computer modelling with the two component NEWMOD program, which was kindly placed at my disposal by R.C.Reynolds, was carried out for $\mathrm{Cu}$ radiation with the (001) values for smectite from above and for $\mathrm{Mg}^{2+}$ - saturated specimens with following parameters: $0.8 \mathrm{~K}$ per illite layer, 0.3 octahedral $\mathrm{Fe}$ per layer in both illite and smectite, and a cation exchange capacity (CEC) of 0.4 per smectite layer, all layers as $\mathrm{O}_{10}(\mathrm{OH})_{2}$. Particle thicknesses in computer models were 3-14 2:1 layers. The values for percentages of illite obtained from peak migration calculations were first used in the models and then the models were refined for each specimen by varying $P_{I}, P_{S . I}$ and $P_{\text {SI.I. }}$. The final results of the modelling were compared to the actual diffractograms for both air-dried and glycolated $\mathrm{Mg}^{2+}$ - saturated specimens and the independent results for both specimens finally compared. In all cases the maximum difference between the results for the two specimens agreed within 0.05 in $P_{1}$. 
Table 4b: Mixed-layer illite/smectite from wells in the Norwegian-Danish Basin. Statistical parameters obtained from comparison between recorded and computer simulated X-ray diffraction patterns.

\begin{tabular}{lcccc}
\hline Well & Depth,m & $\mathbf{P}_{\mathbf{I}}$ & $\mathbf{P}_{\text {S.I }}$ & Ordering \\
\hline Frederikshavn 1 & 649 & 0.70 & 0.50 & I-S segregated \\
Uglev 1 & 821 & 0.70 & 0.50 & I-S segregated \\
& 862 & $(0.80)$ & $(3$ comp.?) & \\
Børglum 1 & 986 & 0.65 & 0.45 & I-S segregated \\
J1 & 1012 & 0.75 & 0.55 & I-S segregated \\
Haldager 1 & 1049 & 0.70 & 0.50 & I-S segregated \\
Gassum 1 & 1190 & $(0.80)$ & & \\
& 1191 & $(0.80)$ & & \\
F1 & 1191 & $(0.85)$ & & \\
Hyllebjerg 1 & 1734 & 0.75 & 0.55 & I-S segregated \\
Mors 1 & 1850 & 0.70 & 0.50 & I-S segregated \\
Rønde 1 & 1899 & 0.70 & 0.50 & I-S segregated \\
Aars 1 & 2115 & $(0.85)$ & $(3$ comp.?) & \\
9/4-3 & 2425 & 0.70 & $(3$ comp., 0.15S, 0.15V) \\
& 2465 & 0.70 & $(3$ comp,. 0.15S, 0.15V) \\
\hline N & 2377 & 0.70 & 0.50 & I-S segregated \\
\hline
\end{tabular}

Note: It was difficult to determine the mixed-layering in Rønde 1, Gassum 1 and in Uglev 1, $862 \mathrm{~m}$ because of the large amounts of kaolinite in the illite/smectite fraction and because of broad mixed-layer peaks, probably due to three component mixed layering.

In three cases of random or I-S segregated mixed layering, the modelling of the low-angle region $\left(5^{\circ} 2 \theta\right.$ to $\left.10^{\circ} 2 \theta\right)$ indicated significantly higher smectite percentages than the position of the $(003)_{\mathrm{S}} /(002)_{\mathrm{I}}$. This can be explained by the presence of vermiculite layers so that the $(003)_{\mathrm{S}}{ }^{\prime}$ $(002)_{\mathrm{I}}$ becomes a $(003)_{\mathrm{S}} /(002)_{\mathrm{I}} /(003)_{\mathrm{V}}$ and moves towards higher angles, due to the interference with the $4.7 \AA(003)_{V}$. For these samples, the diffractograms for $\mathrm{Mg}^{2+}$ - saturated, air-dried specimens were modelled with the NEWMOD program, because smectite and vermiculite in this type of specimen have about the same $\mathrm{d}(001)$ and the system may therefore be modelled as twocomponent. For the same samples, the diffractograms for the $\mathrm{Mg}^{2+}$ - saturated, glycolated specimens were modelled with the three-component program kindly placed at my disposal by P. D. Cradwick. The three-component program generally produces less satisfactory fits in the low-angle region since, in the version applied, it only operates with a narrow particle distribution of about 102:1 layers which produces a series of additional (001) interferences due to particle thickness. Therefore, the result of applying the three-component model is less accurate than of applying the NEWMOD program when only two components are present. However, the three-layer modelling strongly indicated both illite, vermiculite and smectite layers to be present in the mixed-layers from G1, $3441 \mathrm{~m}$, and Aars 1A, $2425 \mathrm{~m}$ and 2465 $\mathrm{m}$, and maybe in Rønde 1 and Uglev 1, $862 \mathrm{~m}$. Large amounts of kaolinite in the illite/smectite fractions from Gassum 1, Rønde 1 and Uglev 1, $862 \mathrm{~m}$, made the interpretation of the diffractograms uncertain.

After plots of chemical composition versus $P_{I}$ had been made (Lindgreen, Jacobsen \& Jakobsen 1991), the end-member smectite and illite compositions were calculated. These end-members contained $0.2 \mathrm{Fe}$ (illite) and $0.7 \mathrm{Fe}$ (smectite) and $0.6\left(\mathrm{~K}\right.$ plus equivalent $\left.\mathrm{NH}_{4}{ }^{+} \times 10 / 18\right)$ (illite) and had a CEC of 0.7 (smectite), all figures per $\mathrm{O}_{10}(\mathrm{OH})_{2}$. New computer simulations with these figures and based on particle thicknesses 3-7 or 3-14 unit layers (2:1 units) were made and again compared to the diffractograms. Some mixedlayers fitted best to the 3-7 unit layer and others best to the 3-14 unit layer simulations. However, the new chemical data did not change the simulated curves significantly.

The $P_{I}$ values obtained from simulations of $\mathrm{Mg}^{2+}$ - saturated, air-dried specimens agreed within 0.05 with the $P_{I}$ values obtained for the 

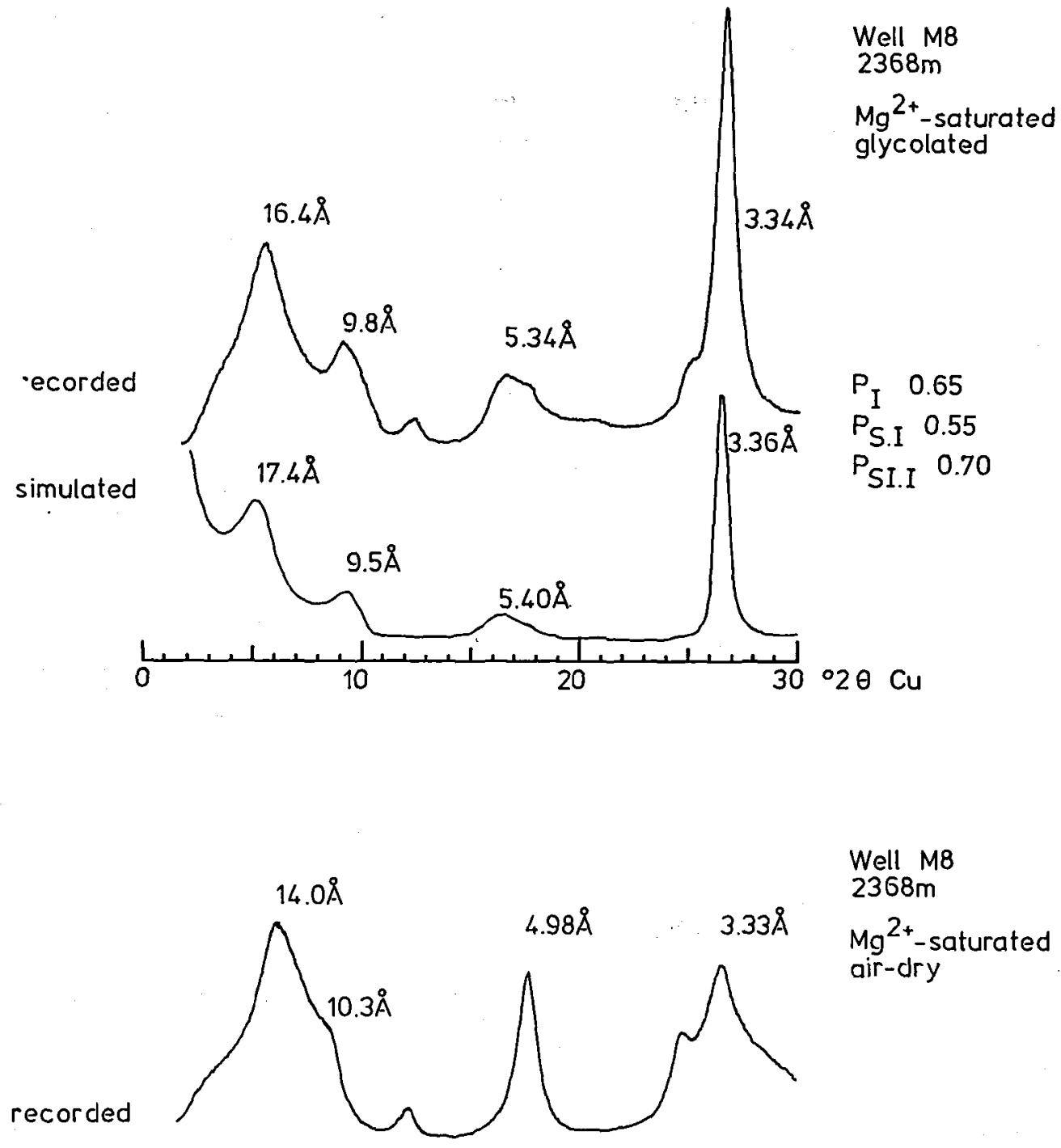

Well M8

2368m

$\mathrm{Mg}^{2+}$-saturated

air-dry

$P_{1} \quad 0.70$

$P_{\text {S.I }} 0.47$

PSI.I 0.80

simulated

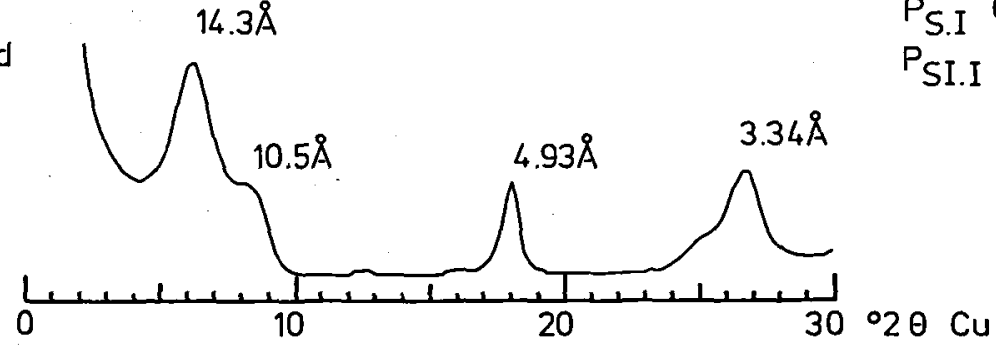

Fig. 11a. Illite/smectite from the Central Trough, well M8, $2368 \mathrm{~m}$ depth. Recorded X-ray diffractograms of oriented specimens prepared from illite/smectite fractions, shown together with diffractograms computer simulated with the NEWMOD program of R. C. Reynolds. $\mathrm{Mg}^{2+}$ - saturated and glycolated (1) and $\mathrm{Mg}^{2+}$ - saturated and air-dried (2). 

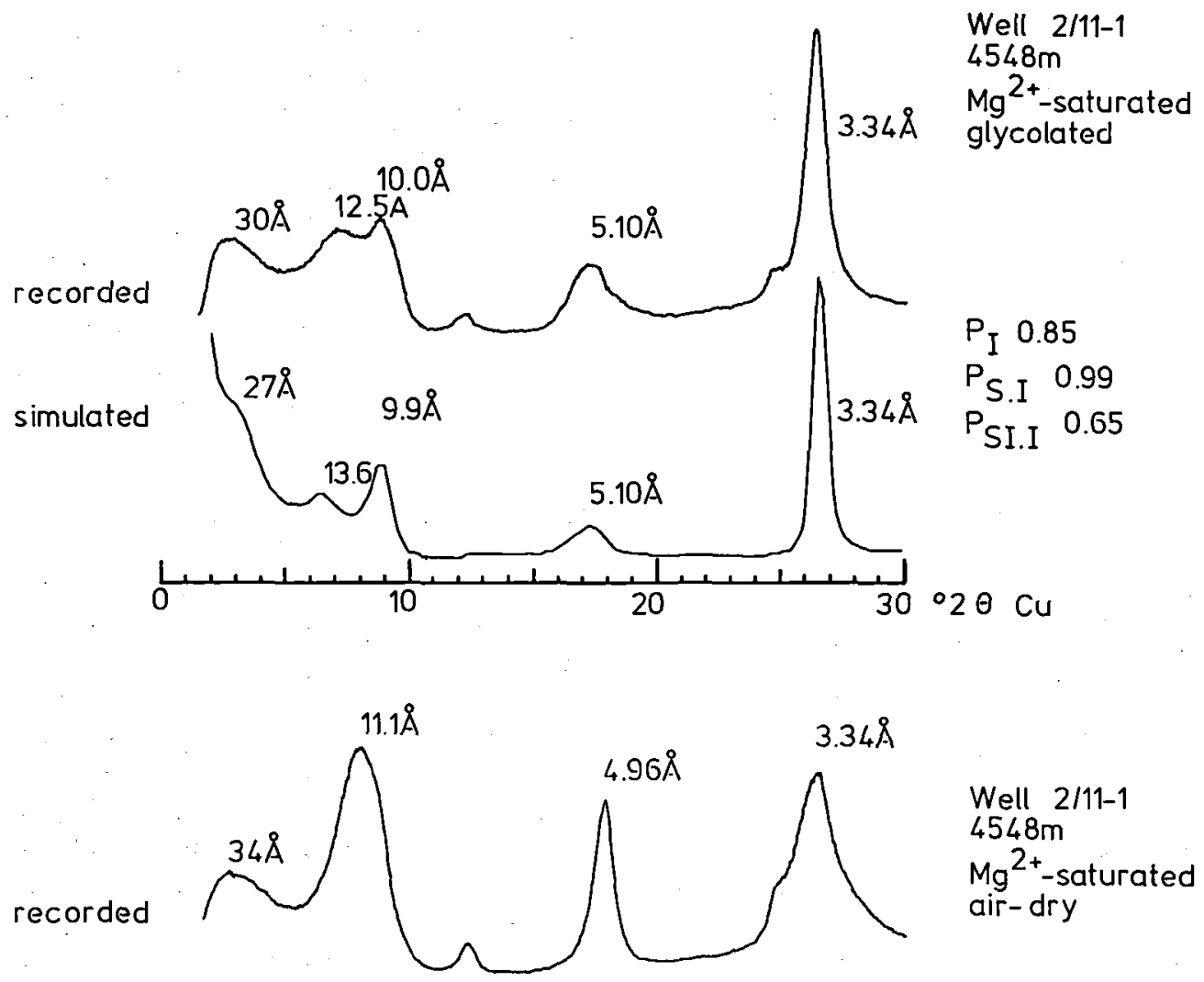

simulated

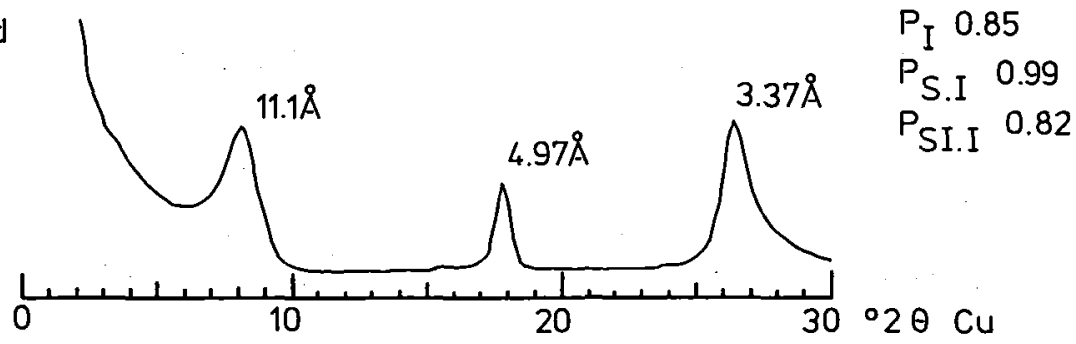

Fig. 11b. Illite/smectite from the Central Trough, well 2/11-1, $4548 \mathrm{~m}$ depth. Recorded X-ray diffractograms of oriented specimens prepared from illite/smectite fractions, shown together with diffractograms computer simulated with the NEWMOD program of R. C. Reynolds. $\mathrm{Mg}^{2+}$ - saturated and glycolated (1) and $\mathrm{Mg}^{2+}$ - saturated and air-dried (2).

$\mathrm{Mg}^{2+}$ - saturated, glycolated specimens. The degrees of ordering obtained by simulation were for some samples slightly higher for air-dried illite/ smectite than for glycolated illite/smectite. For example, the experimental pattern for the sample from well G1, $2609 \mathrm{~m}$, in the air-dried specimen was close to the modelled pattern with $\mathrm{P}_{\text {S.I }} 0.88$, i.e. half IS ordered, whereas the experimental pattern of the glycolated illite/smectite from the same sample resembled the modelled pattern with $P_{\text {S.I }} 0.65$, i.e. I-S segregation.

The result of the modelling of the glycolated patterns is seen in tables $4 a$ and $b$ and selected modelled patterns with the corresponding, measured diffractograms in figs. 11a and $b$.

As mentioned above, MacEwan \& Wilson (1984) concluded that glycerol solvation of $\mathrm{Mg}^{2+}$ saturated specimens is the best basis for distinguishing between vermiculites and smectites. The 


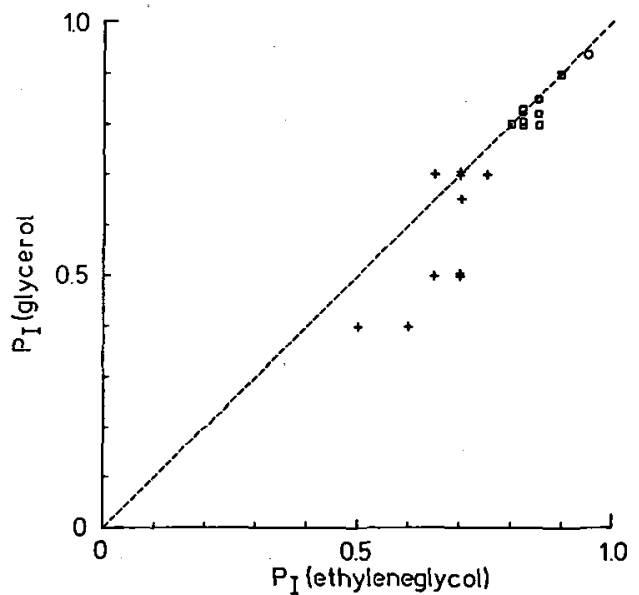

Fig. 12. Illite/smectite from the North Sea and onshore Denmark. X-ray diffraction of oriented specimens of illite/smectite fractions. CuKa radiation. The $\mathrm{P}_{\mathrm{I}}$ values obtained from $\mathrm{Mg}^{2+}$ saturated and glycerolated specimens vs. the $P_{I}$ values obtained from $\mathrm{Mg}^{2+}$ - saturated and ethyleneglycolated specimens. $(+)=$ randomly ordered or I-S segregated, $(\square)=$ IS ordered and $(Q)$ $=$ ISII ordered illite/smectite.

diffractograms of the $\mathrm{Mg}^{2+}$ - saturated and glycerolated specimens were therefore investigated for ordering and amount of illite in illite/smectite by comparison with computermodelled diffractograms calculated for $\mathrm{Mg}^{2+}$ - saturated illite/smectite with ethyleneglycol in the smectite interlayers (because the structure of the glycerol complex is not known). $\mathrm{A} \mathrm{d}(001)$ of $17.8 \AA$ as seen in the experimental diffractograms of glycerolated specimens was used. The error arising from using the 2-layer ethyleneglycol complex instead of a 2layer glycerol complex should be small because of the low scattering power from the light atoms in the organic compounds. The $P_{I}$ values and ordering of illite/smectite obtained by comparing such simulated patterns with the patterns of $\mathrm{Mg}^{2+}$ saturated, glycerolated specimens of Central Trough illite/smectite fractions are plotted in fig. 12 versus the $P_{I}$ and ordering values obtained for the same illite/smectite samples from $\mathbf{M g}^{2+}$ - saturated and ethyleneglycolated specimens (given in table $4 a$ ). This plot shows that $0.1-0.2$ higher values for $P_{1}$ are obtained from ethyleneglycolated specimens than for glycerolated specimens for four samples with low $P_{I}(0.5-0.7)$ in ethyleneglycol, but that the agreement between $P_{1}$ for ethyleneglycolated specimens and for glycerolated specimens is otherwise good $\left(\leq 0.05 \mathrm{P}_{\mathrm{I}}\right)$. The $P_{I}$ values for $\mathrm{Mg}^{2+}$ - saturated and air-dried specimens and for $\mathrm{Mg}^{2+}$ - saturated and ethyleneglycolated specimens of the same sample agreed within $0.05 P_{I}$ (see above). The higher $P_{I}$ values obtained for the four samples for ethyleneglycolated or air-dried specimens than for glycerolated specimens show that glycerolation has kept some layers expanded at a d(001) of $17.8 \AA$, whereas these layers were contracted to a $d(001)$ of $10 \AA$ in ethyleneglycolated or air-dried specimens. None of the standard minerals of MacEwan \& Wilson (1984) showed a similar behaviour. The layers showing this behaviour must have a high charge to keep them contracted in $\mathrm{Mg}^{2+}$ - saturated, air-dried or ethyieneglycolated specimens. On the other hand, a vermiculitic charge should only allow uptake of one glycerol layer giving a d(001) of $14 \AA$ according to MacEwan \& Wilson (1984). A high charge of a layer may, however, keep layers contracted to $10 \AA$ when air-dried and the subsequant exposure to ethyleneglycol vapours may then be unable to expand the interlayer space, whereas glycerol under wet condition may be able to intercalate these layers and keep them expanded during and after drying. The different behaviour when exposed to ethyleneglycol vapour and to glycerol may therefore be due to a high charge of the layers.

\section{Discrete clay minerals and non-clay minerals}

\section{Bulk rock samples}

XRD on randomly oriented specimens showed that the claystones contained the following minerals: quartz, plagioclase feldspar, illite and kaolinite. Potassium feldspars were neither detected by optical microscopy (H. Micheelsen; pers.com.) nor by XRD in the samples from the Central Trough. Quartz was determined quantitatively (accuracy estimated to ${ }^{ \pm} \%$ ) from XRD on randomly oriented specimens with quartz 4.5-45 $\mu \mathrm{m}$ size as external standard and measurement of peak areas for the (1010), (1011) and $(1 \overline{1} \overline{0})$ reflections. The ratio between calcite and (dolomite + ankerite) was determined from the ratio between the areas of the (10 $\overline{14})$ reflections of these minerals. The contents of gypsum, calcite + dolomite + ankerite, siderite, pyrite and organic carbon were determined by differential 
Tab. 5a. Quantitative mineralogy (except for clay minerals) of samples from the Central Trough. Determined by X-ray diffraction plus differential thermal analysis with quantitative detection of evolved $\mathrm{H}_{2} \mathrm{O}, \mathrm{CO}_{2}$ and $\mathrm{SO}_{2}$.

\begin{tabular}{|c|c|c|c|c|c|c|c|}
\hline Well, depth, m & $\begin{array}{c}\text { Organic } \\
\text { Carbon } \\
\%\end{array}$ & $\begin{array}{c}\text { Quartz } \\
\%\end{array}$ & $\begin{array}{c}\text { Pyrite } \\
\%\end{array}$ & $\begin{array}{c}\text { Gypsum } \\
\%\end{array}$ & $\begin{array}{c}\text { Calcite } \\
\%\end{array}$ & $\begin{array}{c}\text { Dolomite }+ \\
\text { ankerite } \\
\%\end{array}$ & $\begin{array}{c}\text { Siderite } \\
\%\end{array}$ \\
\hline \multicolumn{8}{|l|}{ E1 } \\
\hline $2983 \mathrm{~m}$ & 8.2 & 25 & 3.8 & 0.1 & 2 & - & - \\
\hline $3938 \mathrm{~m}$ & 2.0 & 25 & 0.8 & - & 10 & 5 & 1 \\
\hline \\
\hline $2609 \mathrm{~m}$ & 1.6 & 25 & 1.7 & - & 9 & 3 & - \\
\hline $3441 \mathrm{~m}$ & 1.4 & 20 & 0.9 & - & 5 & 16 & 1 \\
\hline \multicolumn{8}{|l|}{ M8 } \\
\hline $2368 \mathrm{~m}$ & 3.3 & 20 & 0.3 & - & 5 & 5 & - \\
\hline $2387 \mathrm{~m}$ & 1.7 & 20 & 1.4 & - & 6 & 4 & - \\
\hline $2588 \mathrm{~m}^{*}$ & 2.1 & 20 & 0.5 & - & 4 & 5 & - \\
\hline $2725 \mathrm{~m}$ & 1.9 & 15 & 1.1 & - & 2 & 14 & - \\
\hline \multicolumn{8}{|l|}{ U1 } \\
\hline $2542 \mathrm{~m}$ & 2.3 & 20 & 1.3 & - & 11 & 11 & - \\
\hline $2716 \mathrm{~m}$ & 2.1 & 15 & 0.4 & - & 8 & 11 & - \\
\hline $2899 \mathrm{~m}$ & 2.1 & 15 & 0.8 & - & 4 & 6 & - \\
\hline \multicolumn{8}{|l|}{ I1 } \\
\hline $3371 \mathrm{~m}$ & 8.0 & 30 & 3.8 & - & 12 & 4 & - \\
\hline $3908 \mathrm{~m}$ & 3.2 & 20 & 2.8 & - & 3 & 9 & - \\
\hline \multicolumn{8}{|l|}{$2 / 11-1$} \\
\hline $3633 \mathrm{~m}^{*}$ & 5.5 & 15 & 0.3 & - & 12 & - & 1 \\
\hline $3877 \mathrm{~m}$ & 4.9 & 30 & 1.0 & - & - & - & - \\
\hline $4548 \mathrm{~m}$ & 4.5 & 15 & 1.0 & - & 6 & 2 & 1 \\
\hline \multicolumn{8}{|l|}{$2 / 7-3$} \\
\hline $3365 \mathrm{~m}$ & 1.2 & 15 & - & - & 4 & - & - \\
\hline $3789 \mathrm{~m}^{*}$ & 7.4 & 15 & 1.2 & 0.1 & 11 & 5 & - \\
\hline $4178 \mathrm{~m}^{\prime}$ & 5.3 & 20 & 1.1 & - & 4 & 3 & - \\
\hline \multicolumn{8}{|l|}{ Lulu 1} \\
\hline $3420 \mathrm{~m}$ & 3.5 & 20 & 2.4 & - & 3 & 7 & - \\
\hline \multicolumn{8}{|l|}{ W1 } \\
\hline $3816 \mathrm{~m}$ & 2.5 & 30 & 1.0 & - & - & - & - \\
\hline \multicolumn{8}{|l|}{ Adda 1} \\
\hline $2917 \mathrm{~m}$ & 3.5 & 20 & 0.8 & - & 3 & 3 & 1 \\
\hline
\end{tabular}

"Sample $2 / 11-1,3633 \mathrm{~m}$ contains $20 \%$ barite and samples $\mathrm{M} 8,2588 \mathrm{~m}$ and $2 / 7-3,3789 \mathrm{~m}$ contain each $5 \%$ barite.

thermal analysis with determination of evolved $\mathrm{CO}_{2}, \mathrm{H}_{2} \mathrm{O}$ and $\mathrm{SO}_{2}$. The thermal analysis instruments are described by Morgan (1977). The results of these quantitative determinations are given in tables $5 \mathrm{a}$ and $5 \mathrm{~b}$. The total clay fraction constituted about $50 \%$ of the samples, and the ratio of coarse clay to fine clay was about 0.5 . The isolated illite/smectite fraction constituted about $3 / 4$ of the fine clay fraction. Optical microscopy ( $\mathrm{H}$. Micheelsen, pers. com.) showed, however, that the coarse clay and the sand plus silt fractions were dominated by clay aggregates. The persistency of aggregation despite chemical and physical pretreatments has been found in several other investigations, one of them being Hower et al. (1976).
Cox \& Gallois (1981) described the lithologies of the Kimmeridge Clay in Dorset. In the Central Trough, the hand picked dark-grey lithologies which have been analysed in the present investigation and the two core samples (E1, $2983 \mathrm{~m}$ and 2/11-1, $3877 \mathrm{~m}$ ) belong, from their content of organic carbon, to the lithologies of Cox and Gallois as follows: either oil shale (10-45\% kerogen)(E1, $2983 \mathrm{~m}$; 11, $3371 \mathrm{~m}$; and 2/7-3, $3789 \mathrm{~m})$; dark grey mudstone ( $<2 \%$ kerogen) $(2 / 7-3,3365$ $\mathrm{m})$; or to the bituminous mudstones $(2-10 \% \mathrm{ke}-$ rogen)(the remaining samples). It is noteworthy that sample $2 / 7-3,3365 \mathrm{~m}$, contains a markedly lower amount of organic carbon (1.2\%) than the other Central Trough samples analysed. This could be due to a bentonitic origin. The carbon- 
Tab. 5b. Quantitative mineralogy (except for clay minerals) of samples from wells in the Norwegian-Danish Basin. Determined by $X$-ray diffraction plus differential thermal analysis with quantitative detection of evolved $\mathrm{H}_{2} \mathrm{O}, \mathrm{CO}_{2}$ and $\mathrm{SO}_{2}$.

\begin{tabular}{|c|c|c|c|c|c|c|c|}
\hline Well, depth, m & $\begin{array}{c}\text { Organic } \\
\text { Carbon } \\
\%\end{array}$ & $\begin{array}{c}\text { Quartz } \\
\%\end{array}$ & $\begin{array}{c}\text { Pyrite } \\
\%\end{array}$ & $\begin{array}{c}\text { Gypsum } \\
\%\end{array}$ & $\begin{array}{c}\text { Calcite } \\
\%\end{array}$ & $\begin{array}{c}\text { Dolomite }+ \\
\text { ankerite } \\
\%\end{array}$ & $\begin{array}{c}\text { Siderite } \\
\quad \%\end{array}$ \\
\hline $\begin{array}{l}\text { Frederikshavn } \\
1\end{array}$ & & & & & & & \\
\hline $649 \mathrm{~m}$ & 1.1 & 25 & 0.8 & 0.5 & - & - & - \\
\hline $\begin{array}{l}\text { Uglev } 1 \\
821 \mathrm{~m} \\
862 \mathrm{~m}\end{array}$ & $\begin{array}{l}1.0 \\
1.6\end{array}$ & $\begin{array}{l}25 \\
15\end{array}$ & $\begin{array}{l}0.5 \\
2.6\end{array}$ & $\overrightarrow{0.1}$ & $\begin{array}{l}6 \\
-\end{array}$ & $\begin{array}{l}15 \\
-\end{array}$ & $-\overline{3}$ \\
\hline $\begin{array}{l}\text { Børglum } 1 \\
986 \mathrm{~m}\end{array}$ & 0.9 & 40 & 0.4 & 0.1 & 1 & 1 & - \\
\hline $\begin{array}{l}\text { J1 } \\
1012 \mathrm{~m}\end{array}$ & 0.7 & 15 & 3.4 & 3.2 & 1 & - & - \\
\hline $\begin{array}{l}\text { Haldager } 1 \\
1049 \mathrm{~m}\end{array}$ & 1.0 & 20 & 0.7 & 0.4 & - & - & - \\
\hline $\begin{array}{l}\text { Gassum } 1 \\
1190 \mathrm{~m} \\
1191 \mathrm{~m} \\
1191.2 \mathrm{~m}\end{array}$ & $\begin{array}{l}0.4 \\
0.4 \\
0.4\end{array}$ & $\begin{array}{l}30 \\
15 \\
20\end{array}$ & - & $\begin{array}{l}- \\
- \\
-\end{array}$ & $\begin{array}{l}- \\
- \\
-\end{array}$ & $\begin{array}{l}- \\
- \\
-\end{array}$ & $\begin{array}{l}- \\
- \\
-\end{array}$ \\
\hline $\begin{array}{l}\text { Hyllebjerg } 1 \\
1850 \mathrm{~m}\end{array}$ & 1.0 & 30 & 2.3 & 0.1 & 4 & 3 & - \\
\hline Mors 1 & 0.5 & 20 & 3.2 & - & 6 & 2 & - \\
\hline $\begin{array}{l}\text { Rønde } 1 \\
2115 \mathrm{~m}\end{array}$ & 2.8 & 20 & 1.2 & - & 4 & - & 1 \\
\hline $\begin{array}{l}\text { Aars } 1 \\
2425 \mathrm{~m} \\
2465 \mathrm{~m}\end{array}$ & $\begin{array}{l}2.7 \\
0.9\end{array}$ & $\begin{array}{l}30 \\
25\end{array}$ & $\begin{array}{l}2.3 \\
3.5\end{array}$ & $\begin{array}{c}0.2 \\
-\end{array}$ & $\begin{array}{l}7 \\
2\end{array}$ & $\begin{array}{l}4 \\
2\end{array}$ & $\overline{0.3}$ \\
\hline $\begin{array}{l}9 / 4-3 \\
2377 \mathrm{~m} \\
2435 \mathrm{~m}\end{array}$ & $\begin{array}{l}2.2 \\
5.7\end{array}$ & $\begin{array}{l}25 \\
15\end{array}$ & $\begin{array}{l}1.2 \\
2.1\end{array}$ & $\begin{array}{l}0.5 \\
0.3\end{array}$ & $\begin{array}{l}3 \\
9\end{array}$ & $\begin{array}{l}5 \\
2\end{array}$ & $\begin{array}{l}1 \\
-\end{array}$ \\
\hline
\end{tabular}

ate content of the investigated samples $(0-16 \%)$ is low compared to the range of $10-25 \%$ calcium carbonate given by Cox \& Gallois for the oil shale and the bituminous mudstone. Gallois (1976) proposed that coccolith blooms, in an environment between open ocean and an enclosed marine basin, formed the Kimmeridge Clay oil shales. Tyson, Wilson \& Downie (1979) suggested, however, that the bituminous shale-oil shale - coccolith limestone lithologic association characteristic of the type Kimmeridge Clay can be attributed to the vertical movement of the $\mathrm{O}_{2}: \mathrm{H}_{2} \mathrm{~S}$ interface in a temporarily stratified water column. Wignall (1989) proposed that during deposition of the Kimmeridge Clay storms caused oxygenation of anoxic bottom layers. The generally low amounts of pyrite (exceptions are: E1, $2983 \mathrm{~m}$; I1, $3371 \mathrm{~m}$; and Lulu 1, $3420 \mathrm{~m}$ ) could indicate that anoxic conditions have not prevailed for a long time in the sediments in- vestigated. Diagenesis may, however, have caused a later dissolution of pyrite. The samples from the Norwegian-Danish Basin are low in organic carbon (exceptions are the samples from 9/4-3) compared to the Central Trough samples. The quartz content is generally the same (15$30 \%$ ), indicating that near-shore sediments are not present. The samples from Gassum 1 have markedly low contents of organic carbon and do not contain pyrite or carbonates. This could be the result of uplift and weathering during Upper Jurassic, as is also indicated by the clay mineralogy (see below).

Carbonate bands in the claystone

Sonic and gamma ray logs of Upper Jurassic sections in the Central Trough have several sharp peaks. X-ray diffraction of side-wall cores from wells $\mathrm{G} 1$ and $\mathrm{E} 1$ showed that the peaks in these 
Tab. 6a. Clay mineralogy of $2-0.2 \mu \mathrm{m}$ fraction from wells in the Central Trough as determined by X-ray diffraction of oriented specimens.

\begin{tabular}{|c|c|c|c|c|c|}
\hline \multirow[t]{2}{*}{ Well depth, $m$} & \multicolumn{5}{|c|}{$\%$ reflection area } \\
\hline & kaolinite & illite . & I/S & vermiculite & chlorite \\
\hline \multicolumn{6}{|l|}{ E1 } \\
\hline $\begin{array}{l}2983 \mathrm{~m} \\
3444 \mathrm{~m}\end{array}$ & 38 & 23 & $38(x)$ & - & - \\
\hline $\begin{array}{l}3444 \mathrm{~m} \\
3938 \mathrm{~m}\end{array}$ & $\begin{array}{l}27 \\
17\end{array}$ & 48 & $25(\mathrm{y})$ & - & - \\
\hline $3938 \mathrm{~m}$ & 17 & 37 & $46(y)$ & - & - \\
\hline $\begin{array}{l}\text { G1 } \\
2609 \mathrm{~m}\end{array}$ & \multicolumn{4}{|c|}{ G1 } & 1 \\
\hline $3441 \mathrm{~m}$ & 16 & 48 & $36(\mathrm{x})$ & - & - \\
\hline \multicolumn{6}{|l|}{ M8 } \\
\hline $2368 \mathrm{~m}$ & 24 & 27 & $50(x)$ & - & - \\
\hline $2387 \mathrm{~m}$ & 31 & 24 & $43(x)$ & - & 1 \\
\hline $2588 \mathrm{~m}$ & 28 & 23 & $48(\mathrm{x})$ & - & 1 \\
\hline $2725 \mathrm{~m}$ & 33 & 31 & $29(y)$ & - & 7 \\
\hline \multicolumn{6}{|l|}{ U1 } \\
\hline $2542 \mathrm{~m}$ & 20 & 21 & $58(x)$ & - & - \\
\hline $2716 \mathrm{~m}$ & 13 & 26 & $61(x)$ & - & - \\
\hline $2899 \mathrm{~m}$ & 14 & 30 & $56(x)$ & - & 1 \\
\hline \multicolumn{6}{|l|}{ I1 } \\
\hline $3371 \mathrm{~m}$ & 45 & 14 & $40(z)$ & - & - \\
\hline $3441 \mathrm{~m}$ & 40 & 28 & $32(z)$ & - & - \\
\hline $3688 \mathrm{~m}$ & 20 & 46 & $33(z)$ & - & - \\
\hline $3908 \mathrm{~m}$ & 19 & 41 & $41(z)$ & - & - \\
\hline \multicolumn{6}{|l|}{$2 / 11-1$} \\
\hline $3633 \mathrm{~m}$ & 24 & 15 & $61(z)$ & - & - \\
\hline $3877 \mathrm{~m}$ & 12 & 32 & $56(\mathrm{z})$ & - & - \\
\hline $4548 \mathrm{~m}$ & 13 & 26 & $61(z)$ & - & - \\
\hline \multicolumn{6}{|l|}{$2 / 7-3$} \\
\hline $3502 \mathrm{~m}$ & 15 & 3 & $82(x)$ & - & - \\
\hline $3789 \mathrm{~m}$ & 27 & 51 & $22(y)$ & - & - \\
\hline $4178 \mathrm{~m}$ & 17 & 35 & $48(y)$ & - & - \\
\hline $\begin{array}{l}\text { Lulu } 1 \\
3420 \mathrm{~m}\end{array}$ & 43 & 37 & $21(y)$ & - & - \\
\hline \multicolumn{6}{|l|}{ W1 } \\
\hline $3816 \mathrm{~m}$ & 12 & 8 & $77(x)$ & - & 2 \\
\hline $4051 \mathrm{~m}$ & 14 & 20 & $67(y)$ & - & - \\
\hline \multicolumn{6}{|l|}{ Adda 1} \\
\hline $\begin{array}{l}2633 \mathrm{~m} \\
2917 \mathrm{~m}\end{array}$ & $\begin{array}{l}33 \\
26\end{array}$ & $\begin{array}{l}12 \\
28\end{array}$ & $\begin{array}{l}55(x) \\
46(x)\end{array}$ & $\begin{array}{l}- \\
-\end{array}$ & - \\
\hline $2917 \mathrm{~m}$ & 26 & 28 & $46(x)$ & 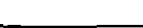 & - \\
\hline
\end{tabular}

$(\mathrm{x})$ : random ordering or I-S segregated

(y): IS, ISI, or ISII ordered

(z): IS ordered

wells are caused by carbonate bands in the claystone. Similar log peaks were present in the cored well section of the Norwegian well 2/11-1. Investigation of this cored section (Lindgreen 1985) showed that the carbonate bands consisted of claystone fragments, coarse grains of dolomite, quartz, and siderite, and of diagenetic layer silicates, all cemented by ankerite. The diagenetic layer silicates were kaolinite being neoformed into muscovite. This neoformation is similar to the process seen in the Cambrian sandstone of
Sahara by Millot (1970) and in Middle Jurassic Brent sandstone by Hancock \& Taylor (1978). In these rocks, formation of kaolinite was related to an early infiltration of fresh, neutral to weakly acid solutions and a later formation of mica from kaolinite was linked to infiltration of alkaline, saline solutions. Lindgreen (1985) concluded by analogy that the kaolinite in the carbonate bands had formed during an early release of fresh, neutral solutions from the claystone and the subsequant neoformation of mica from kaolinite dur- 
Tab. 6b. Clay mineralogy of $2-0.2 \mu \mathrm{m}$ fraction from wells in the Norwegian Danish Basin as determined by $\mathrm{X}$-ray diffraction of oriented specimens.

\begin{tabular}{|c|c|c|c|c|c|}
\hline \multirow[t]{2}{*}{ Well depth, m } & \multicolumn{5}{|c|}{$\%$ reflection area } \\
\hline & kaolinite & illite & I/S & vermiculite & chlorite \\
\hline \multicolumn{6}{|l|}{$\begin{array}{l}\text { Frederikshavn } \\
1\end{array}$} \\
\hline $649 \mathrm{~m}$ & 54 & 17 & $26(x)$ & 2 & - \\
\hline \multicolumn{6}{|l|}{ Uglev 1} \\
\hline $862 \mathrm{~m}$ & 50 & 16 & $32(x)$ & 1 & 1 \\
\hline \multicolumn{6}{|l|}{ Børglum 1} \\
\hline 986 m & 51 & 31 & $18(x)$ & - & - \\
\hline \multicolumn{6}{|l|}{$\mathrm{J} 1$} \\
\hline $1012 \mathrm{~m}$ & 47 & 17 & $33(x)$ & 2 & 1 \\
\hline \multicolumn{6}{|l|}{ Haldager 1} \\
\hline \multicolumn{6}{|l|}{ Gassum 1} \\
\hline $1190 \mathrm{~m}$ & 67 & 15 & $17(x)$ & - & - \\
\hline $1191 \mathrm{~m}$ & 88 & 3 & $9(x)$ & - & - \\
\hline $1191.2 \mathrm{~m}$ & 67 & 13 & $21(x)$ & - & - \\
\hline \multicolumn{6}{|l|}{ F1 } \\
\hline $1734 \mathrm{~m}$ & 40 & 14 & $44(x)$ & 2 & - \\
\hline Hyllebjerg 1 & 43 & 31 & $24(\mathrm{x})$ & - & 2 \\
\hline \multicolumn{6}{|l|}{ Mors 1} \\
\hline $1899 \mathrm{~m}$ & 31 & 24 & $43(x)$ & - & 1 \\
\hline \multicolumn{6}{|l|}{ Rønde 1} \\
\hline $2115 \mathrm{~m}$ & 56 & 12 & $27(x)$ & 5 & - \\
\hline \multicolumn{6}{|l|}{ Aars 1} \\
\hline $\begin{array}{l}2425 \mathrm{~m} \\
2465 \mathrm{~m}\end{array}$ & 44 & 31 & $24(x)$ & - & 2 \\
\hline \multicolumn{6}{|l|}{ 9/4-3 } \\
\hline $2377 \mathrm{~m}$ & 27 & 25 & $48(x)$ & - & - \\
\hline $2435 \mathrm{~m}$ & 36 & 25 & $39(x)$ & - & - \\
\hline
\end{tabular}

(x): random ordering or I-S segregated

ing a later release of alkaline, saline solutions. Lindgreen (1985) proposed that the carbonate bands had formed through fracturing of the claystone. Scotchman (1988) questioned this and suggested that they were silty beds resembling the thin sandstone layers in the Northern North Sea. Lindgreen (1988) rejected Scotchman's explanation because of the carbonate lithology of the bands and because extremely thin bands $(\sim 0.1$ $\mathrm{mm}$ wide) of the same lithology in the claystone of E1 (Lindgreen 1987a) clearly cannot have a detrital origin. Also, diagenetic quartz formation was observed in very thin bands in the claystone from M8 (Lindgreen 1987a). The claystone was later cored in well Elin 1 and this core has inclined fractures filled with ankerite. Wignall
(1989) discussed the influence of tempests and earthquakes on the Kimmeridge Clay of Dorset. He proposed that silt laminae and thin graded mud horizons were storm produced events and that fissures were earthquake-induced. The carbonate bands and the fractures in Elin 1 may well have been induced by earthquakes. Whatever the origin, the carbonate bands present beautiful examples of clay neoformation in coarse lithologies, mainly controlled by the chemistry of the migrating solutions, like shown by Hancock \& Taylor (1978), whereas the claystone itself shows illite/ smectite diagenesis mainly controlled by the chemical composition of the rock (see below). 
Discrete clay minerals

It is beyond the scope of this publication to give a detailed description of discrete clay mineralogy and of the origin of these minerals. The mineralogy of the coarse clay fraction will be discussed below under the assumption that it is largely of detrital origin because of the large grain size. The composition of this fraction should then reveal the mineralogy of the source rocks for the illite/ smectite. Furthermore, detrital illites may release potassium for formation of illite layers in illite/ smectite (Hower et al. 1976).

Clay mineralogical data for the coarse clay fraction are given in tables $6 a$ and $6 b$ and were discussed by Hansen \& Lindgreen (1989). Traces of chlorite were found by XRD in the sand-and silt fraction, in the coarse clay fraction and in the remaining part (remaining from the isolation of the illite/smectite fraction) of the fine-clay fraction of most samples from the Norwegian-Danish Basin. Exceptions were the samples from the wells Gassum 1 and Rønde 1 and from the Tau Formation in 9/4-3, where chlorite was not found. Traces of chlorite were also found by $\mathrm{XRD}$ in the corresponding fractions from the Central Trough samples in wells M8, G1 and U1 and in the sample $W 1,3816 \mathrm{~m}$. In the deepest sample in M8, from $2725 \mathrm{~m}$, the (001) chlorite peak was sharper and a little larger relatively to the samples above as described for diagenetic chlorite in the Mesozoic shales from the Sleipner field by Hurst (1982). Chlorite was not detected by XRD in the deepest samples with the highest vitrinite reflectancy and degree of ordering in mixed-layers such as in wells $2 / 11-1$, I1 (except in one sample from $3908 \mathrm{~m}$ ), 2/7-3 and E1. Therefore, a general diagenetic formation of chlorite as described in the Gulf Coast Tertiary sediments (Hower et al. 1976; Ahn \& Peacor 1985 and 1987) and in the North Sea Mesozoic sediments from the Sleipner Field (Hurst 1982) is not found by XRD in the present investigation of the Kimmeridgian-Volgian(-Ryazanian) claystones in the Central Trough and the Norwegian-Danish Basin. Diagenetic chlorite formation may, however, have taken place in M8. The traces of chlorite found in the other wells are probably detrital as proposed by Hurst (1985a) for some of the chlorites from the Sleipner Field. Diagenetic chlorite was, however, found by optical microscopy of the sand and silt fraction from all Central Trough wells (Micheelsen \& Lindgreen, in prep.), even if in too small amounts to be seen in XRD.

Traces of vermiculite were found in the coarse clay fractions of Rønde 1, F1, J1, Frederikshavn 1 and in the deepest sample from Uglev 1 but not in the Central Trough (tables 6a and b). Its occurrence in these onshore well samples with a high kaolinite/illite peak area ratio (see below) makes a detrital origin probable.

Two factors determine the composition of the detrital clays: 1 ) the clay mineralogy of the source area; and 2) clay mineral segregation in the depositional environment. The importance of the source area was demonstrated by Milne \& Earley (1958) for Recent sediments and by the review of Weaver (1959).

Delfaud (1983) discussed the Jurassic sedimentary facies of Western Europe and concluded from the character of the sediments that the climate was relatively hot during Lower Lias, Dogger and Upper Portlandian and was more temperate in Upper Lias and Kimmeridgian. The end of the Jurassic and the beginning of the Cretaceous showed an increase in temperature and in humidity. The climate was Mediterranian in the North Sea region. Francis (1984) discussed the climate of Volgian (Purbeck) fossil forests in Dorset, UK, and concluded that the climate was of the Mediterranian type with warm, wet winters and hot, arid summers. Hurst (1985b) investigated the clay mineralogy of the Jurassic sediments from Brora, NE Scotland and discussed the implications of clay mineralogy to palaeoclimate and provenance. Brora was close to a landmass, lying within a semi-enclosed marine basin, and therefore the effect of clay particle segregation, according to Hurst, could be assumed to be minimal. The clay mineralogy was dominated by illite, kaolinite and (mostly ordered) illite/ smectite. The source of the illite/smectite, according to Hurst, was Devonian rocks, whereas he proposed that the kaolinite probably originated from erosion of Carboniferous regoliths. His arguments were that the kaolinite had formed prior to the Jurassic, since erosion and sedimentation of the ordered illite/smectite could not have taken place in a climate with kaolinite formation during weathering. $\mathrm{He}$ proposed therefore that the climate during Upper Jurassic was sub-tropical. 
Porrenga (1965) investigated the clay mineralogy of recent sediments of the Niger Delta and found that montmorillonite increased and kaolinite decreased in amount with distance from the shore. Illite was only present in small amounts in the samples and variation in the illite content with distance from shore was not apparent. Porrenga carried out settling experiments with the Niger Delta clays in samples of ocean water and found that kaolinite increased slightly in proportion during early sedimentation and montmorillonite later. $\mathrm{He}$ attributed this to differential flocculation such that illite and kaolinite flocculate and settle faster than montmorillonite when they come into salt water. Parham (1966) reviewed the literature on coastal lateral variation of clay minerals in modern and ancient sediments. He concluded that the direction of sediment transport can be indicated by lateral variations in clay mineral assemblages as follows: kaolinite decreases outwards from the shore, whereas montmorillonite increases in the same direction. Illite and chlorite increase initially outwards from the shore but then decrease at greater distances from the shore. Parham noted exceptions from these patterns. Some of these exceptions could be due to the fact that sediment contributions from different source areas can overlap and mix irregularly, e.g. in the Gulf of Mexico. But Parham noted that the correlation between clay mineralogy and shore distance, even if seen in the majority of studies, could neither be detected in investigations from recent sediments off the North Carolina coast nor off the coast of California. Gibbs (1977) investigated clay mineral segregation in Amazon River sediments deposited in the Atlantic Ocean. He found that differential flocculation was not important, and that this was probably because of natural coatings of oxides and organic matter on the clays. Instead he found that the dominant clay mineral segregation mechanism was a physical sorting by size. The results of Porrenga (1965), Parham (1966) and Gibbs (1977) indicate then that not only is the type of clay mineral important for sedimentation in the ocean water but also the sizes of the minerals in the clay fraction and an eventual coating of the clay minerals by oxides and organic matter.

Sellwood \& Sladen (1981) argued that the volume of mud deposited in the Kimmeridgian was too large to have been derived from local source lands in the British area. They therefore proposed that the clays originated to a large extent from the more distant hinterlands of GreenlandN.America and Scandinavia. Sellwood (1972) found that the predominating clay minerals in Liassic shales from Britain are illite and kaolinite. He concluded that these minerals probably reflect the nature of the source areas in the region and that decreasing kaolinite contents in these sediments reflect greater distance from source areas. Bjørlykke, Dypvik \& Finstad (1975) found in well $2 / 11-1$ an average increase in the kaolinite/illite peak area ratio by a factor of about 3 from $4100 \mathrm{~m}$ to $3500 \mathrm{~m}$ depth and thought that this increase reflected a higher degree of proximity to deltaic or shoreline facies in a regressional sequence. They alternatively proposed that this increase in the kaolinite/illite peak area ratio may be due to a climatic change towards more humid conditions at the end of Upper Jurassic. Wignall \& Ruffell (1990) calculated kaolinite/illite ratios from clay mineralogical data given by Deconinck, Chamley, Debrabant \& Colebeaux (1983) for Upper Jurassic marine strata marginal to the Boulonnais shore in Northern France. Wignall \& Ruffell found that high kaolinite/illite ratios reflected shallow water and low distance to the shore. Wignall \& Ruffell (1990) found that onset of aridity in the middle of the Hudlestoni ammonite zone (in Early Volgian) produced a low kaolinite/illite peak area ratio in Kimmeridge clay from Kimmeridge Bay, Southern England, but that the ratio then fluctuated during the arid times later in the Hudlestoni zone and in the Pectinatus ammonite zone (at the end of Early Volgian). Wignall \& Ruffell could not explain these fluctuations.

In the present investigation, illite was found in all coarse clay fractions (tables $6 a$ and $b$ ) and may be largely considered detrital because of its grain size and because the illite reflection area does not vary with sample depth. It probably originated from erosion of parent rocks which were little weathered. It should be noted, however, that overgrowths of authigenetic mica were seen by optical microscopy of the sand and silt fractions from the Central Trough (Micheelsen \& Lindgreen, in prep.).

Kaolinite was found in all fractions and the amount did not vary with diagenesis in any fraction. It is therefore most probably detrital and 


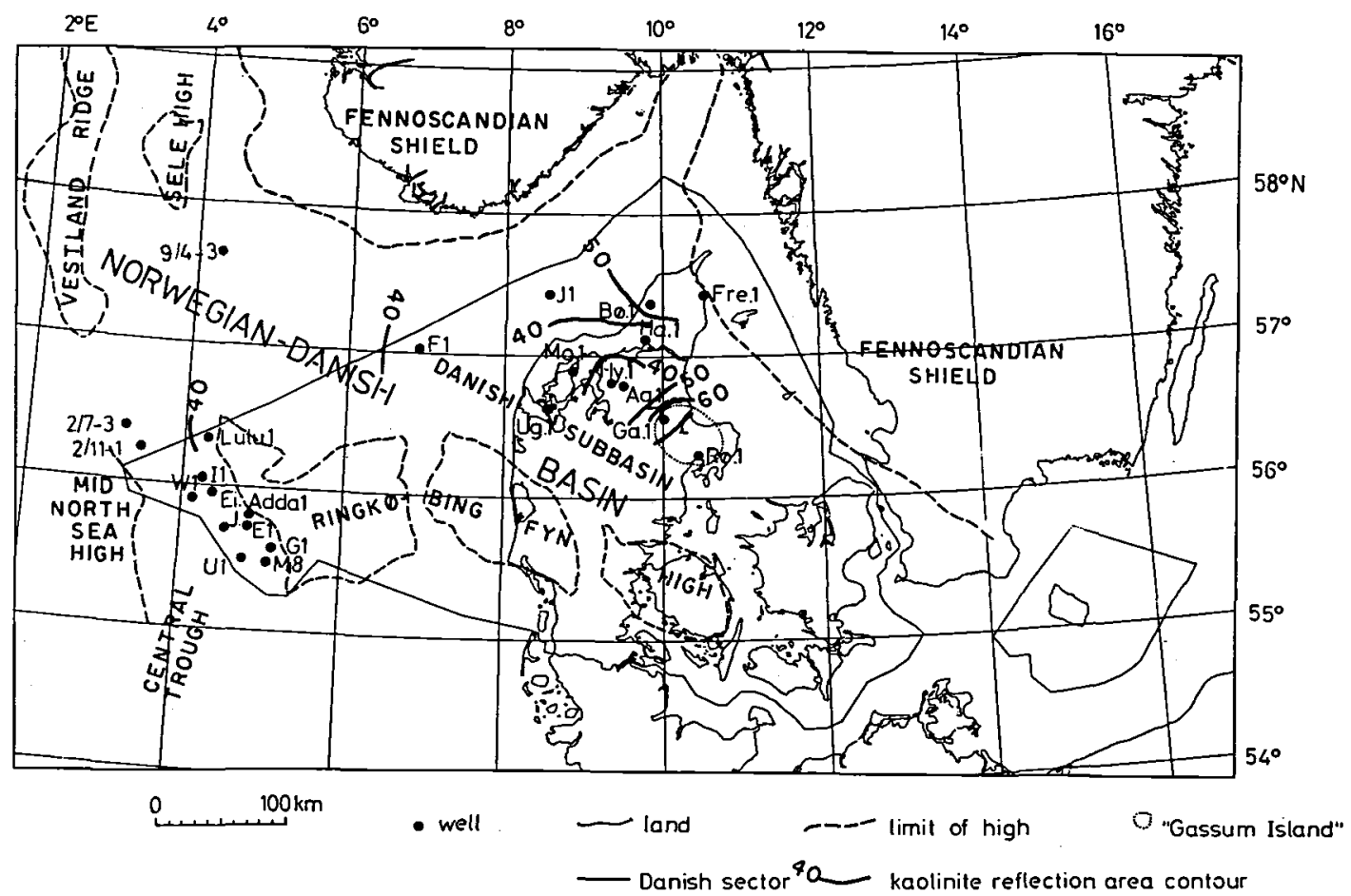

Fig. 13. Kaolinite reflection area contours for samples from the Norwegian-Danish Basin and from the Central Trough. X-ray diffraction of oriented samples of the coarse clay fraction.

(Lower part in well Uglev $1(862 \mathrm{~m})$ is higher in kaolinite than the upper part (representing the well in the contour map). This may be due to uplift and weathering of the lower part of the Bream Formation in this well during Upper Jurassic (salt movements)). Abbreviations: Bø. 1: Børglum 1; Fre. 1: Frederikshavn 1; Ga. 1: Gassum 1; Ha. 1: Haldager 1; Hy. 1: Hyllebjerg 1; Mo. 1: Mors 1; Rø. 1: Rønde 1; Ug. 1: Uglev 1; Aa. 1: Aars 1.

results from erosion of land surfaces which in earlier times had undergone weathering in a semi-humid tropical climate, in agreement with the proposals of Hurst (1985b). The kaolinite reflection area $(\%)$ for the coarse clay fractions from the Bream, Børglum, Sauda and Tau formations from the Norwegian-Danish Basin is given in table $6 \mathrm{~b}$ and plotted on the map in fig. 13. The samples from Rønde 1 and Gassum 1 are very high in kaolinite and this will be discussed below. For the other wells, a decrease in the amount of kaolinite with distance from the Fennoscandian Shield can be seen. This may be taken to indicate that the main source area for the Upper Jurassic claystones is the Fennoscandian Shield, in agreement with Larsen (1966), who concluded from a heavy mineral study that transport in the Danish Embayment (the Danish Subbasin) was predominantly from the north or north-east. A climatic change can not be the explanation for the variation in the ratio for the samples from the Norwegian-Danish Basin. Firstly, because samples from the top of the Børglum Formation (in Aars $1,2425 \mathrm{~m}(17 \mathrm{~m}$ from the top of a $71 \mathrm{~m}$ thick formation) and in $\mathrm{J} 1$ ( $21 \mathrm{~m}$ from the top of a 101 $m$ thick formation) and from the bottom of the same formation (in F1 (17 $\mathrm{m}$ from the bottom in an $83 \mathrm{~m}$ thick formation) and in Aars $1,2465 \mathrm{~m}$ (14 $\mathrm{m}$ from the bottom of the $71 \mathrm{~m}$ thick formation) have about the same kaolinite reflection areas. Secondly, because two samples with high reflection areas, Frederikshavn 1 and Børglum 1 , are taken from the bottom of a $7 \mathrm{~m}$ thick Børglum Formation and $6 \mathrm{~m}$ from the top of a $34 \mathrm{~m}$ thick Børglum Formation, respectively.

The kaolinite/illite peak area ratios for the Central Trough samples do not vary with distance from the local highs, the Mid North Sea High and the Ringkøbing-Fyn High (fig. 13). Therefore, these highs were not-significant source areas during the Upper Jurassic. The kaolinite reflection areas are generally smaller for the Central Trough samples than for the samples from the NorwegianDanish Basin. This fits with the pro- 
refl. Kaolinite
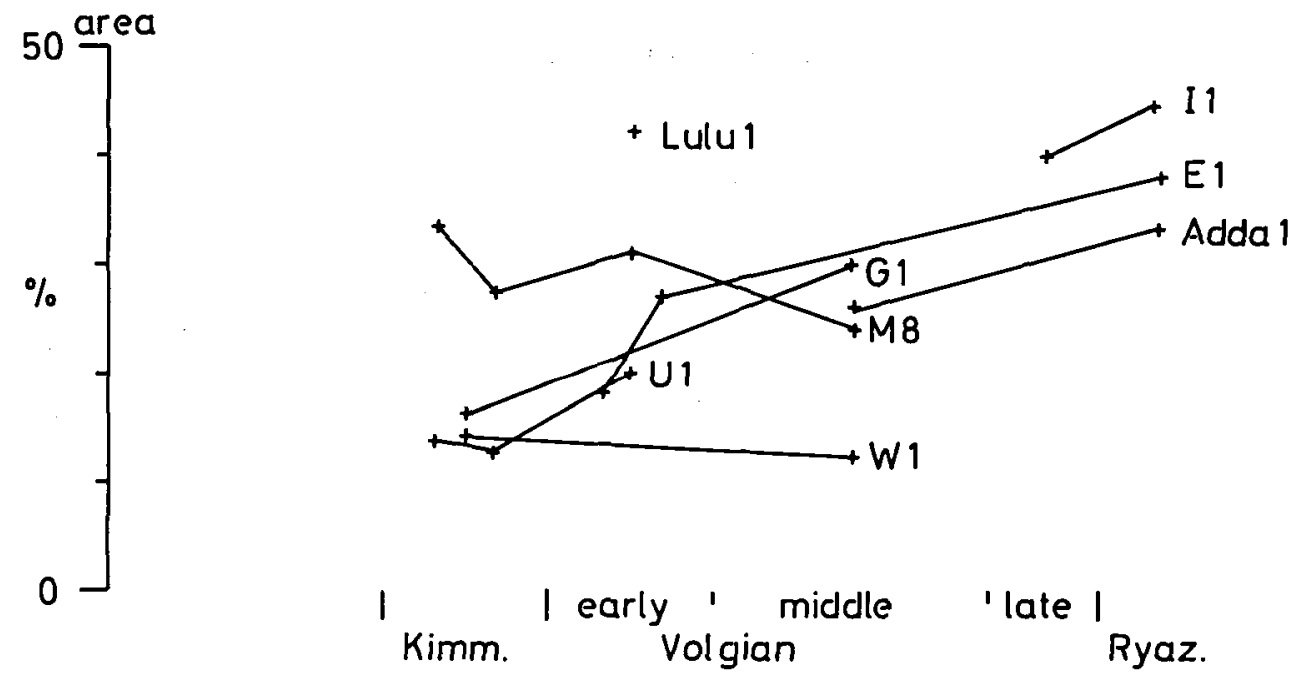

refl. Illite
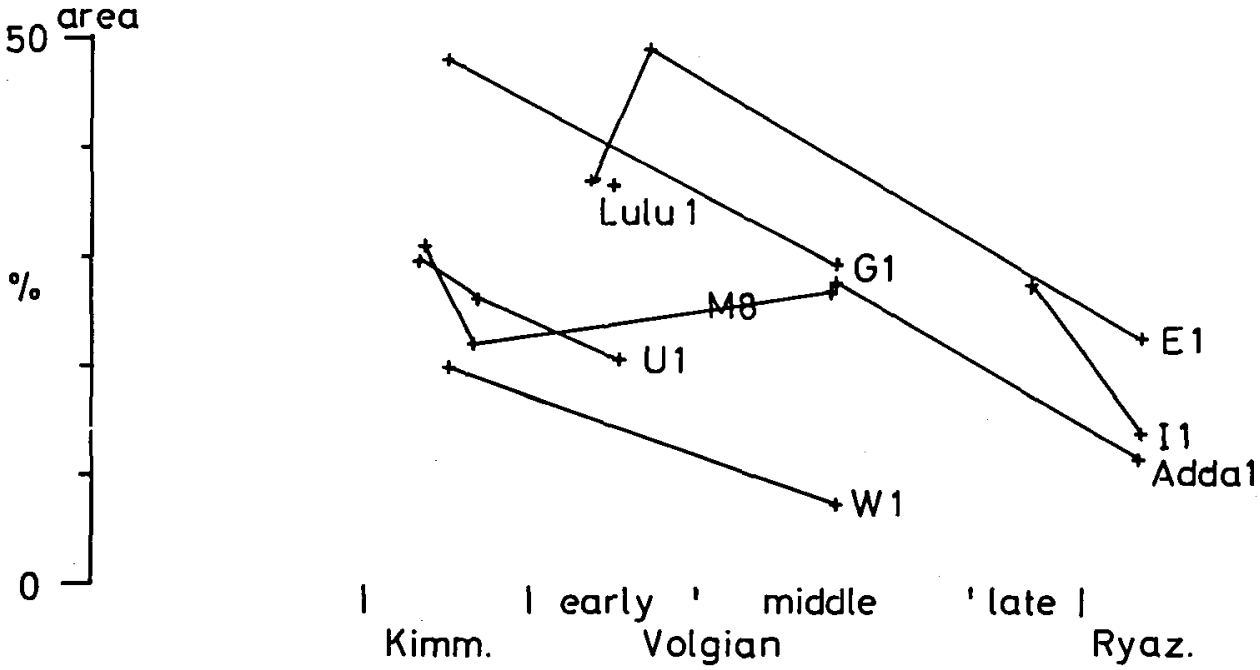

Fig. 14. Discrete clay minerals from the Central Trough. Kaolinite and illite reflection areas vs. chronostratigraphy of sampled intervals. X-ray diffraction of oriented samples of the coarse clay fraction from Central Trough wells.

posal of Sellwood \& Sladen (1981) that the distant hinterlands (Scandinavia in the case of the Central Trough samples) are the main source areas. The time span for the Central Trough deposition (Kimmeridgian - Ryazanian) is larger than for the deposition of the Børglum Formation in the Norwegian-Danish Basin (KimmeridgianMiddle Volgian). Therefore the reflection areas for illite and kaolinite in the coarse clay fraction are plotted vs. time in fig. 14. This figure shows a general increase in kaolinite and a decrease in illite reflection areas from the Kimmeridgian to 
the Ryazanian. This increase is much less than the variation during the more limited time span for the Børglum Formation in the NorwegianDanish Basin and may be due to a change in climate as proposed by Bjørlykke et al. (1975). The decrease in the kaolinite/illite peak area reported at the end of Early Volgian by Wignall \& Ruffell (1990) can not be seen in the present investigation (fig. 14). The large intervals represented by the cuttings samples, however, would make detection of such narrow variations impossible.

The kaolinite peaks at $7.4 \AA$ are broad in the diffractograms from the Rønde 1 and Gassum 1 wells (relatively to the peaks from diagenetic kaolinite reservoirs and in the carbonate bands in 2/11-1) and the samples, especially from Gassum 1 , have a large kaolinite content and a low content of mixed-layer illite/smectite in all fractions; see the diffractograms for the illite/smectite fraction in Hansen \& Lindgreen (1989). This composition is similar to the soil type clay XRD pattern of Hughes, DeMaris, White \& Cowin (1987) for clays from Pennsylvanian strata of the Illinois Basin. Hughes et al. found that this clay assemblage resulted from soil processes during deposition. Soil weathering in emergent sediments may therefore have formed the clays from Gassum 1 and Rønde 1 . The clay mineralogical results thus support the finding of Larsen (1966) that a "Gassum Island" (fig. 13) existed during part of the Upper Jurassic.

Hower et al. (1976) found a higher percentage (about $10 \%$ higher) of illite layers in illite/smectite from the fine clay fraction than in the coarse clay fraction. The large amounts of discrete illite in the present coarse clay fractions made estimation of illite fractions in illite/smectite difficult. But the illite/smectite in the coarse clay fraction appeared similar to the illite/smectite isolated from the corresponding fine clay fraction. There are no indications of a diagenetic change in the discrete minerals of the coarse clay fraction as seen in tables 6a and b. Detrital mica can furnish potassium for the formation of illite layers in the illite/smectite (Hower et al., 1976). Potassium felspars were not detected by microscopy of the silt fractions in the present investigation, and therefore potassium from detrital illite may have played an important role in illite layer formation in illite/smectite also in the North Sea samples.
But the documented presence of significant amounts of ammonium and its fixation together with potassium limit the requirements for potassium from detrital mica.

\section{Layer structure of mixed-layer illite/ smectite}

Variability of illite/smectite in the claystone

Nine samples were investigated from the core of well $2 / 11-1,3863.9 \mathrm{~m}-3877.7 \mathrm{~m}$, in order to assess the variability of illite/smectite in the claystone. The diffractograms were essentially similar in appearance and were dominated by IS ordered illite/smectite with $P_{I} 0.85$. Illite/smectite isolated from the carbonate bands (see above) contained in addition small amounts of randomly ordered or I-S segregated illite/smectite. This may be drilling mud contamination. The uniformity of the illite/smectite patterns from the $2 / 11-1$ core indicates that the illite/smectite mineralogy of the cuttings samples is not the result of mixing of very different lithologies in the intervals sampled and that the amount of illite layers in illite/smectite is fairly constant over short depth intervals.

\section{The nature of segregation}

The MacEwan and the fundamental particle models for illite/smectite are shown in fig. 2 . Segregation means that a sequence of illite layers will statistically be more probable in an illite/smectite sequence than in an ideal randomly, IS, ISI, or ISII ordered sequence. According to the interparticle diffraction concept for illite/smectite (Nadeau et al. 1984), illite/smectite diffraction patterns are the result of interparticle and intraparticle diffraction in samples consisting of very thin illite particles and eventually single layers of smectite. Diffraction in such a mixture of illite particles will have to be simulated either as a segregation of illite layers or as very thin illite particles.

Simulation of experimental XRD patterns of $\mathrm{Mg}^{2+}$ - saturated, air-dried and of $\mathrm{Mg}^{2+}$ saturated, glycolated specimens showed that illite layers in most samples were segregated, as I-S and IS-I segregation in illite/smectite. This is in contrast to information from Bethke \& Altaner 

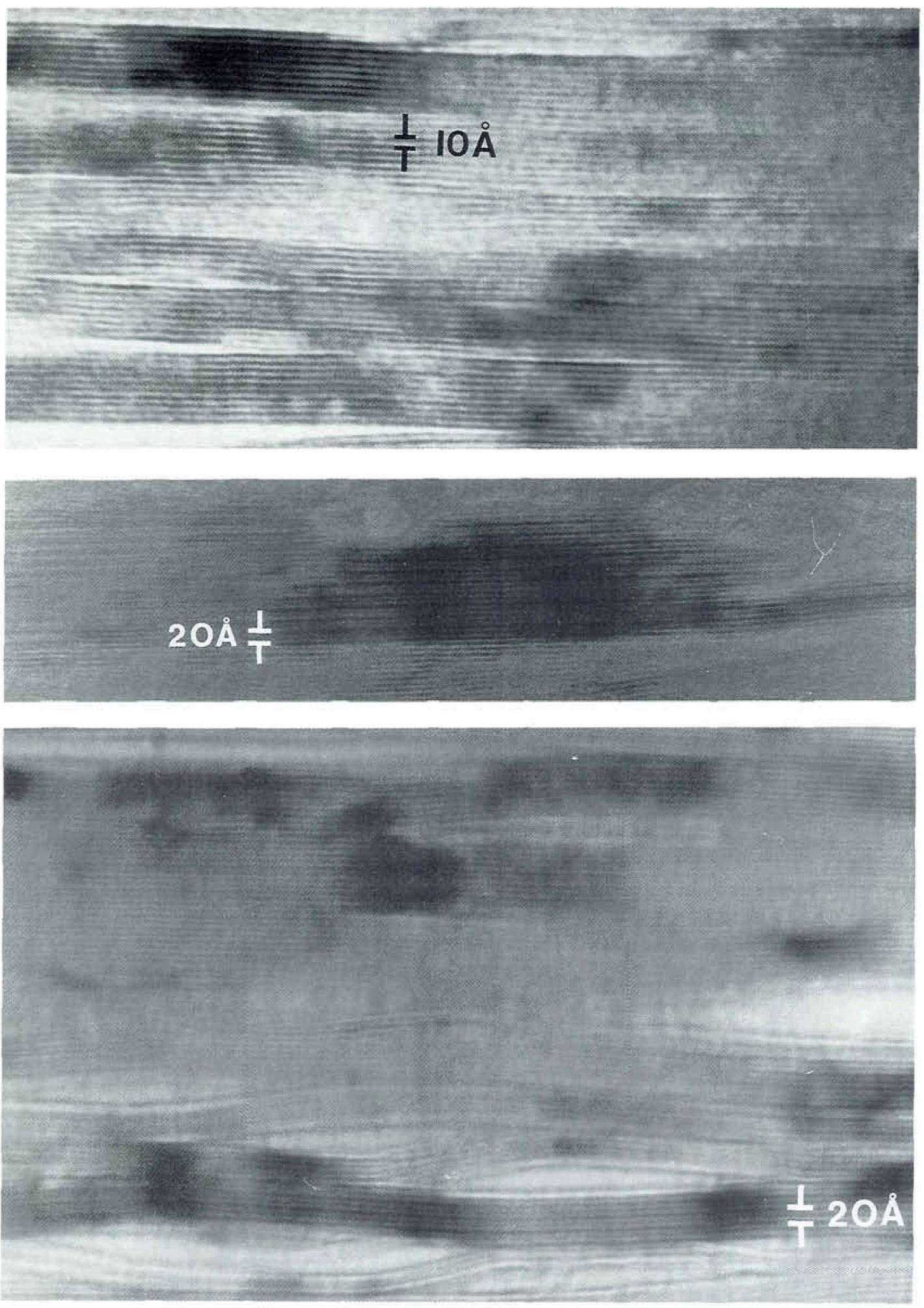

Fig. 15, Bulk rock clays from the Central Trough. High resolution electron microscopy of intact bulk rock samples. a: Well M8 (2387 m); lattice image of lagre crystal with 10 A period in contrast; from Lindgreen \& Hansen (1991, fig. 5), b) Well M8 (2387 m); enhanced contrast is seen in every second lattice fringe giving 20 A periodicity; from Lindgreen \& Hansen (1991, fig. 6). c) Well $2 / 11-1(3877 \mathrm{~m})$; short sequences of $20 \mathrm{~A}$ periods are observed in all specimens investiged from this sample. 

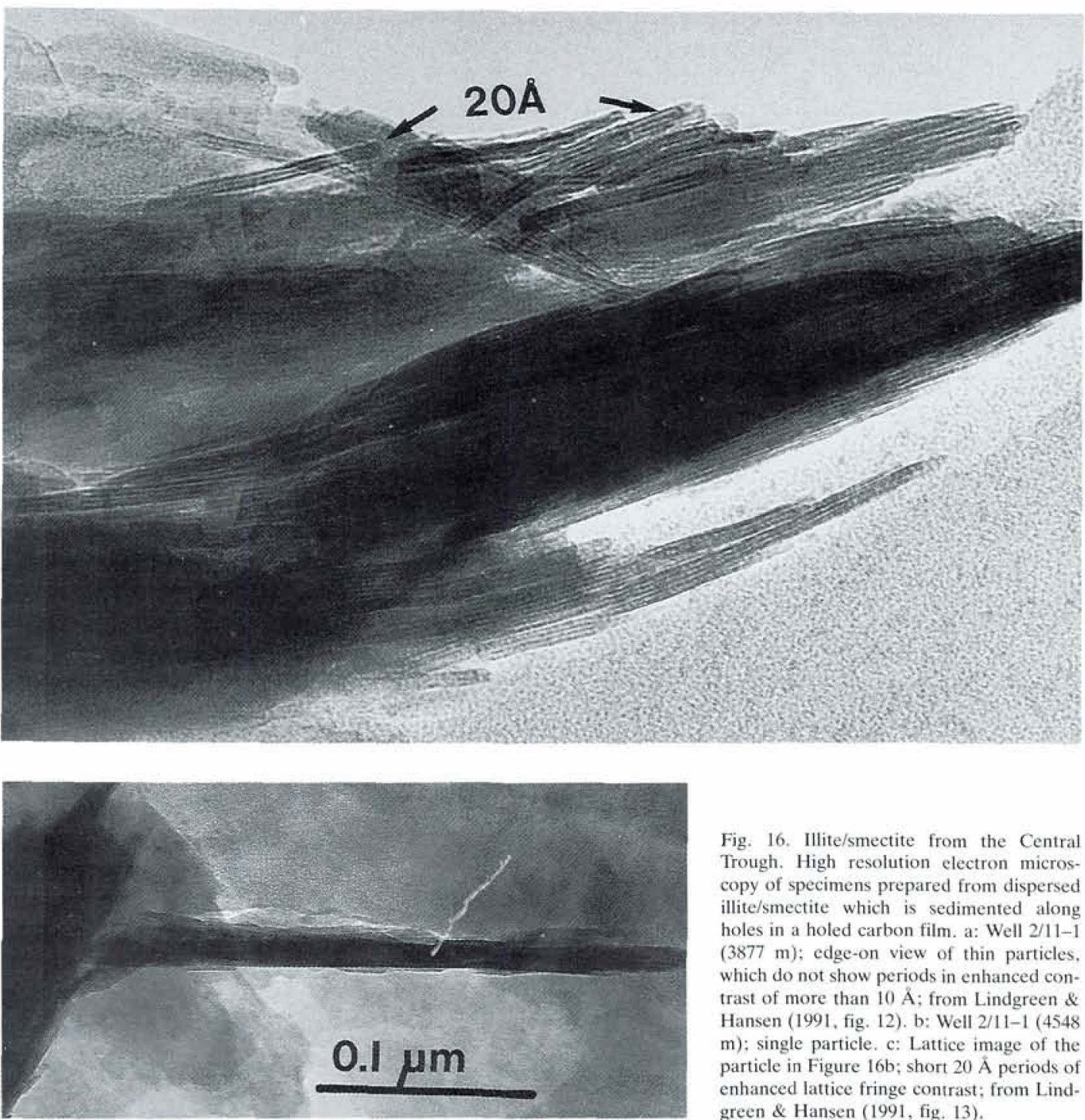

Fig. 16. Illite/smectite from the Central Trough. High resolution electron microscopy of specimens prepared from dispersed illite/smectite which is sedimented along holes in a holed carbon film. a: Well 2/11-1 (3877 m); edge-on view of thin particles, which do not show periods in enhanced contrast of more than $10 \mathrm{~A}$; from Lindgreen \& Hansen (1991, fig. 12), b: Well 2/11-1 (4548 $\mathrm{m})$ : single particle. $\mathrm{c}$ : Lattice image of the particle in Figure 16b; short $20 \mathrm{~A}$ periods of enhanced lattice fringe contrast; from Lindgreen \& Hansen (1991, fig. 13).

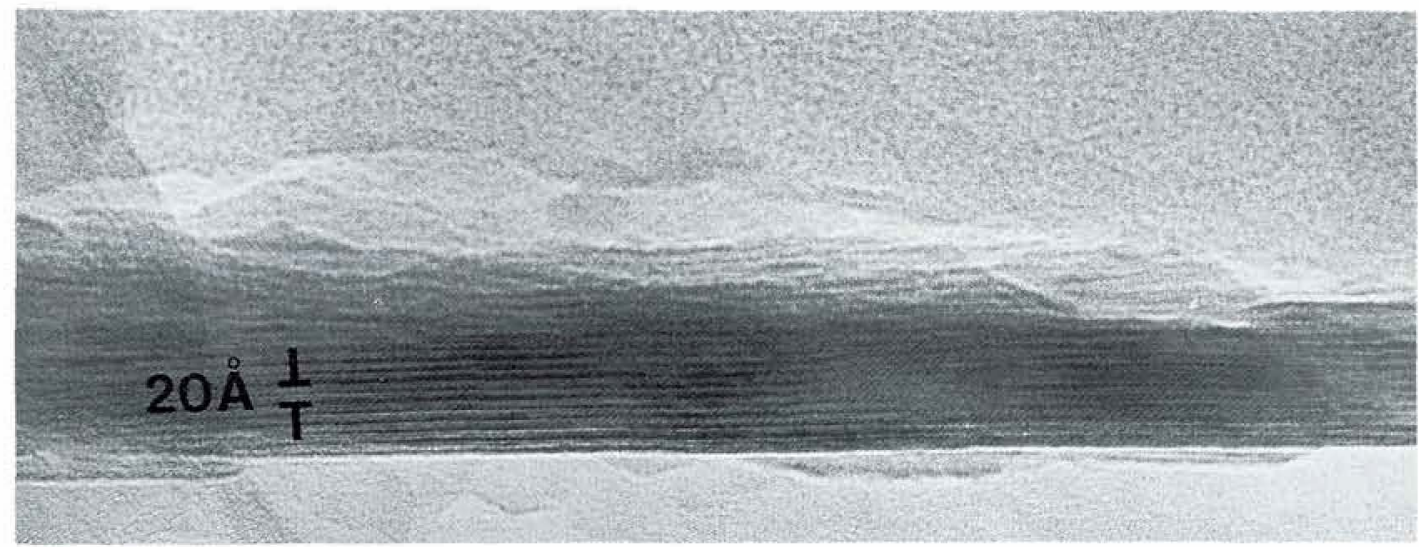




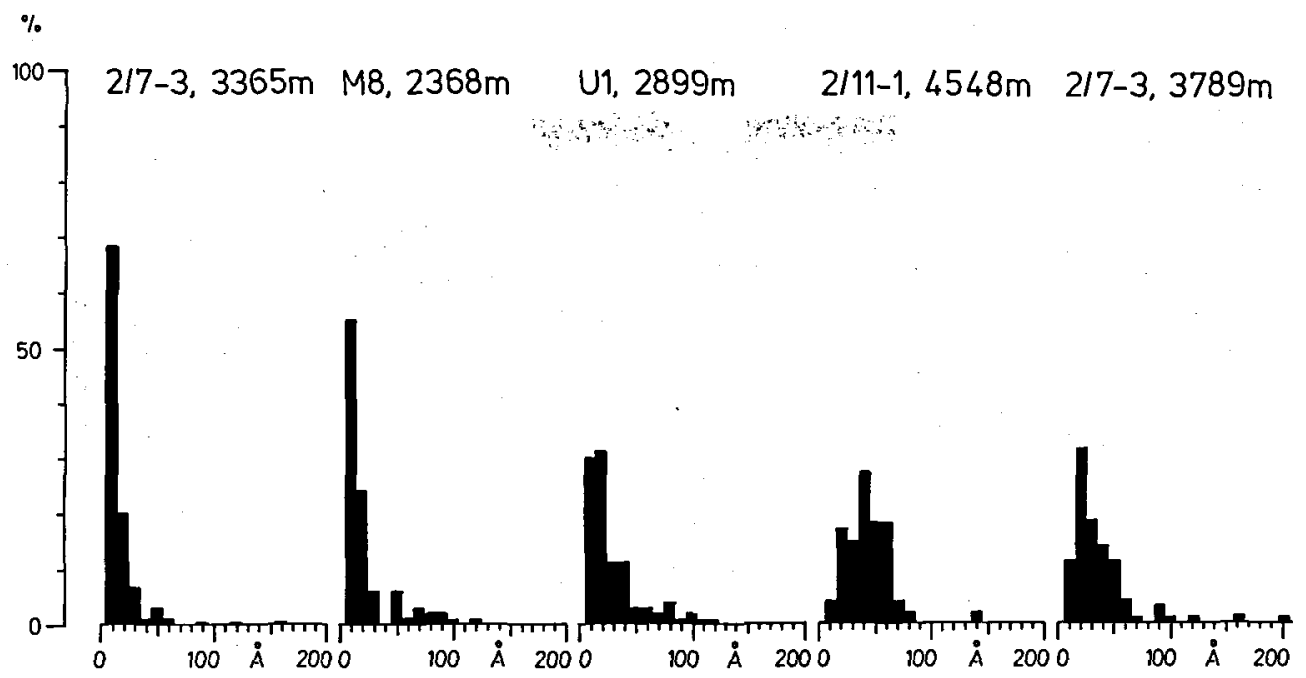

Fig. 17. Illite/smectite from the Central Trough. Particle thickness distributions as calculated from particle thicknesses measured from shadow lengths in transmission electron microscope pictures. Specimens prepared from dispersed illite/smectite fractions.

(1986) that natural illite/smectite is normally not segregated. HRTEM of the present illite/smectite prepared from dispersed $\mathrm{Na}^{+}$- saturated samples and viewed edge-on showed a large number of particles with only $10 \AA$ period in contrast (see later), probably the fundamental illite particles of Nadeau et al. (1984). Such particles were, however, not observed in intact bulk rock and must therefore have been formed by disrupture along smectite layers in larger particles in the bulk rock (see below). Such $10 \AA$ period particles should give segregation in XRD patterns of dispersed samples, as is observed.

Layer structures in intact bulk rock and in dispersed illite/smectite

Ordering of illite and smectite layers in illite/ smectite in intact bulk rock and in dispersed illite/ smectite were investigated and discussed by Lindgreen \& Hansen (1991).

Illite and smectite layers are distinguished in XRD by the constant $\mathrm{d}(001)$ of $10 \AA$ of illite and the swelling of smectite after $\mathrm{Mg}^{2+}$ - saturation and glycerolation to $18 \AA$ (MacEwan \& Wilson 1984). Smectite layers are expanded in natural rocks even at great depths of burial (van Olphen 1963). The preparation of thin sections of intact bulk rock for HRTEM often involves ion milling at vacuum, and a removal of interlayer water in smectite and a subsequent contraction of inter- layers between smectite layers to $10 \AA$ is then highly probable. Even if ball-milling is used for preparation of thin sections, a contraction of smectite interlayers will be very probable in the high vacuum of the electron microscope (Klimentidis \& Mackinnon 1986; Ahn \& Peacor 1986a). Guthrie \& Veblen (1989) showed that lattice fringe $d(001)$ values are only reliable in perfectly oriented specimens. Perfect orientation is, however, difficult to achieve, as illite/smectite crystals are easily destroyed by the electron beam.

Particles showing lattice fringes with only $10 \AA$ period in enhanced contrast were very frequent in bulk rock samples, and an example is shown in fig. 15a. These particles may be illite particles but may also contain contracted smectite layers (see below). Larger lattice fringe $\mathrm{d}(001)$ values were occasionally seen in packets with $10 \AA$ lattice fringes. The $\mathrm{d}(001)$ values of more than $10 \AA$ may be due to interlayered organic matter in the organic-rich Upper Jurassic source rocks. Crystals with lattice fringe $d(001)$ values of $14 \AA$ were observed (Hansen \& Lindgreen 1989). These crystals are probably chlorite as only one spacing (14 $\AA$ ) in lattice fringes was observed. It can be concluded that few or single lattice fringes with a $\mathrm{d}(001)$ of more than $10 \AA$ in crystals with $10 \AA$ lattice fringes are probably smectite or chlorite, whereas lattice fringes with $d(001)$ of $10 \AA$ are due to illite or collapsed smectite. 
10 Å lattice fringes with periodically enhanced contrast were observed by HRTEM on intact bulk rock in all Central Trough samples investigated. Regular $20 \AA$ period sequences of such enhanced contrast were most frequent, but also $30 \AA$ period sequences and sequences with enhanced contrast occurring randomly along $\mathrm{c}^{*}$ were seen (Hansen \& Lindgreen 1989). Particles with $20 \AA$ period in enhanced contrast are shown in fig. 15b and 15c. Computer modelling (Hansen \& Lindgreen 1989) showed that such enhanced contrast in underfocus can be due to alternating interlayers of $\mathrm{K}^{+}$and $\mathrm{Na}^{+}$. Therefore, $\mathrm{Na}+$ - saturated smectite layers between $\mathrm{K}^{+}$- saturated illite layers can show such contrast under appropriate instrumental conditions which involve near perfect orientation of the crystals (Guthrie \& Veblen 1989) and preferentially overfocus (Guthrie \& Veblen 1989), even if enhanced contrast could also be seen in the present investigation in underfocused images. $2 \mathrm{M}$ and $3 \mathrm{~T}$ mica polytypes can also show $20 \AA$ and $30 \AA$ periods of enhanced contrast, respectively, in lattice fringes. The abundance of $20 \AA$ period particles in HRTEM images in the present investigation and the finding of only $1 \mathrm{M}$ mica by XRD of sand+silt, coarse-clay and fine-clay fractions (including the illite/smectite fraction) show that $2 \mathrm{M}$ mica cannot be responsible for most of the $20 \AA$ period particles seen in HRTEM. Stacking of thin illite particles can not be the cause of the enhanced lattice fringe contrast, as dislocations would have occurred frequently in such stacked aggregates. Most of the enhanced lattice fringes seen in intact bulk rock by HRTEM are therefore due to interlayered smectite and illite in illite/smectite (MacEwan) particles. It is important that the enhanced contrast can be caused by interlayering of the lighter cation $\mathrm{Na}^{+}$instead of $\mathrm{K}^{+}$(present in most illites) (Hansen \& Lindgreen 1989). Periodically enhanced contrast can also be caused by the lower amount of cations present between smectite layers than between illite layers (Guthrie \& Veblen 1989), but it must then be more weak. For ammonium illite layers interlayered with smectite, the contrast difference between illite and smectite layers must be neglegible, as the larger number of $\mathrm{NH}_{4}{ }^{+}$between illite layers compared to the smaller number of $\mathrm{Na}^{+}$between smectite layers is counterbalanced by the lower scattering power of $\mathrm{NH}_{4}{ }^{+}$compared to $\mathrm{Na}^{+} . \mathrm{Na}^{+}$ is the dominating cation in pore waters of the claystones investigated here, and this explains why illite/smectite particles with lattice fringes of enhanced contrast are so frequent in the samples. These particles are, according to the arguments above, illite/smectite or MacEwan particles. However, MacEwan particles with $\mathrm{NH}_{4}{ }^{+}$illite layers and $\mathrm{Na}^{+}$- saturated smectite layers will almost certainly show $10 \AA$ period particles resembling illite. Besides, non-perfectly oriented crystals which show $10 \AA$ periods in contrast (like in fig. 15a) may both be illite/smectite and illite, and (contracted) smectite crystals, because nearperfect orientation is required for obtaining the enhanced periods in contrast (Guthrie \& Veblen 1989). $\mathrm{Na}^{+}$was the dominating cation in the Gulf Coast Tertiary shales investigated by Schmidt (1973). The failure of Ahn \& Peacor (1986a) to observe lattice fringes with more than $10 \AA$ periodicity can therefore be attributed to the focusing of their microscope during lattice imaging or to imperfect orientation, according to the computermodelling carried out by Guthrie \& Veblen (1989). Ahn \& Peacor (1989) have later reexamined their pictures and found that slightly overfocused images of the sample with $80 \%$ illite layers and IS ordering (from XRD) had $20 \AA$ periods in enhanced contrast. Ahn \& Peacor modified accordingly their former conclusion (Ahn \& Peacor 1986a) so that the results of XRD on dispersed illite/smectite and of TEM (HRTEM) on intact bulk rock were not incompatible. Veblen, Guthrie, Livi \& Reynolds (1990) examined two ordered illite/smectites of hydrothermal origin by XRD on dispersed samples and by HRTEM on intact bulk rock. They examined strongly overfocused HRTEM images showing larger than $10 \AA$ periods in enhanced contrast and calculated the amount of smectite layers from the number of extra dark fringes. The amount of smectite layers obtained in this way for the two samples agreed well with the amounts obtained from XRD. These results conform with those of the present investigation in that ordering of illite/smectite can be seen by HRTEM on intact bulk rock.

Attempts to disperse the samples and isolate illite/smectite resulted in a fraction dominated by illite/smectite from almost all samples. However, kaolinite, perhaps interlayered with illite and smectite, dominated the illite/smectite fractions 


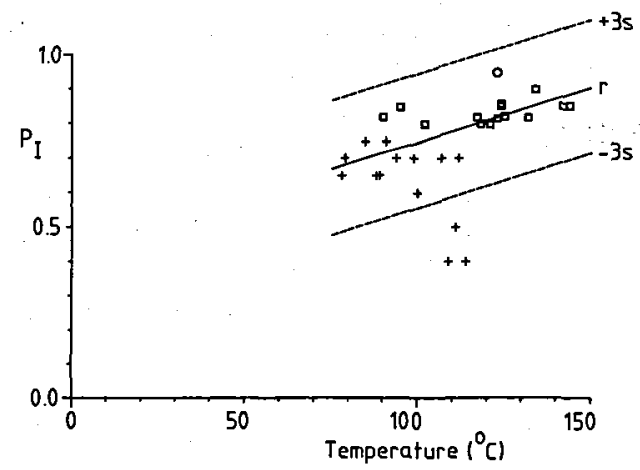

Fig. 18. Illite/smectite from the Central Trough. $P_{I}$ values vs. formation temperatures. $(+)=$ randomly ordered or I-S segregated, $(\square)=$ IS ordered and $(O)=$ ISII ordered illite/smectite. Dotted lines delimit three standard deviations.

from the Gassum 1 and Rønde 1 wells (Hansen \& Lindgreen 1989). Even when the isolation was successful, some of the illite/smectite remained in the coarse clay and coarser fractions during the dispersion and isolation procedure.

Illite/smectite crystals may rupture along smectite layers, as these can disperse and float apart during hydration (Mering \& Oberlin 1971; Altaner et al. 1988; Ahn \& Peacor 1986b). Ahn \& Buseck (1990) showed by HRTEM on ion-milled illite/smectite samples that packets having coherent stacking arrangements were thicker than the fundamental particles in such illite/smectite. They concluded therefore that the "fundamental particles" of Nadeau et al. (1984) are artefacts of sample preparation. If all smectite layers float apart, the illite/smectite crystals will be changed into a mixture of thin illite particles like those seen in a HRTEM picture of dispersed illite/ smectite from well 2/11-1, $3877 \mathrm{~m}$ depth (fig. 16a). Such a mixture of very thin illite particles can then give, by combined inter- and intraparticle diffraction, diffraction patterns resembling those from fundamental illite given by Nadeau et al. (1984). When complete dispersion of smectite layers has been achieved, illite/smectite layer composition can be calculated from a particle thickness distribution measured from TEM as follows: half a bottom and half a top layer of each particle are smectite, the remaining part of each particle is illite (similar to the calculation of $\mathrm{Na}$ deau (1985)), see also fig. 2. The result of such a calculation on the present material is shown in table 7 together with the results of XRD on the same samples and the particle thickness distribu-
Tab: 7. Dispersed illite/smectite from Central Trough samples. Fractions of illite layers and average particle thicknesses (calculated from TEM) and $P_{I}$ values and ordering (obtained from XRD).

\begin{tabular}{lccccc}
\hline I/S fraction & \multicolumn{2}{c}{ TEM } & & \multicolumn{2}{c}{ XRD } \\
\cline { 2 - 3 } \cline { 5 - 6 } & $\begin{array}{c}\text { Fraction } \\
\text { of I }\end{array}$ & $\begin{array}{c}\text { Average } \\
\text { thickness }\end{array}$ & & $\mathrm{P}_{\mathrm{I}}$ & Ordering \\
\hline $2 / 7-3,3365 \mathrm{~m}$ & 0.42 & $17 \AA$ & & 0.40 & random \\
$\mathrm{M} 8,2368 \mathrm{~m}$ & 0.62 & $23 \AA$ & & 0.65 & I-S segr. \\
$\mathrm{U} 1,2899 \mathrm{~m}$ & 0.76 & $30 \AA$ & & 0.70 & I-S segr. \\
$2 / 11-1,4548 \mathrm{~m}$ & 0.89 & $41 \AA$ & & 0.85 & IS \\
$2 / 7-3,3789 \mathrm{~m}$ & 0.84 & $35 \AA$ & & 0.95 & ISII \\
\hline
\end{tabular}

tions (shown in fig. 17) of the illite/smectite fractions as calculated from TEM of the shadowed illite/smectite fractions.

It can be seen from table 7 that the fractions of illite layers calculated from TEM particle thicknesses agree fairly well with the $\mathrm{P}_{\mathrm{I}}$ values obtained by XRD. The poorest agreement is seen for $2 / 7-3,3789 \mathrm{~m}$. For this sample the lack of correspondence between TEM and XRD may be due to the difficulty in assessing a small number of smectite layers by XRD. On the other hand, the sedimentation of thin suspensions of particles on cleaved mica for TEM may have separated layers with a high, smectitic or vermiculitic charge, which may be collapsed in $\mathrm{Mg}^{2+}$-saturated, glycolated specimens and therefore re-

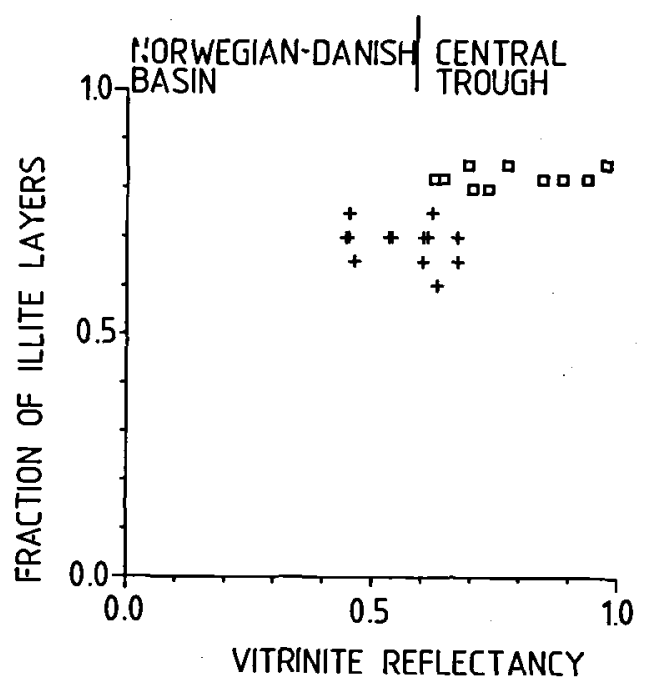

Fig. 19. Illite/smectite from the Norwegian-Danish Basin and the Central Trough. Fraction of illite layers $\left(P_{I}\right.$ values) ys, vitrinite reflectancy values. $(+)=$ randomly ordered or I-S segregated illite/smectite, and $(\square)=$ IS ordered illite/smectite. From Hansen \& Lindgreen (1989, fig. 9). 


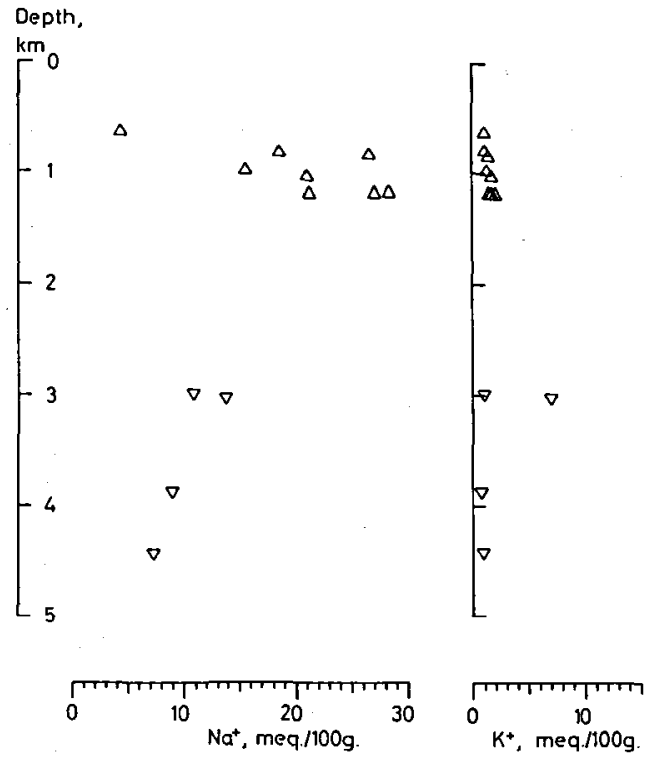

$\Delta$ : core from Norwegian- Danish Basin
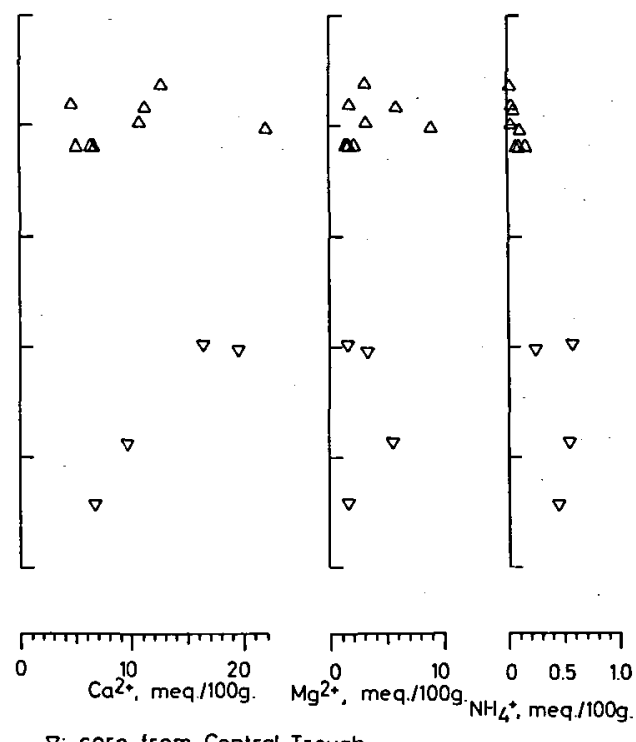

$\nabla:$ core from Central Trough

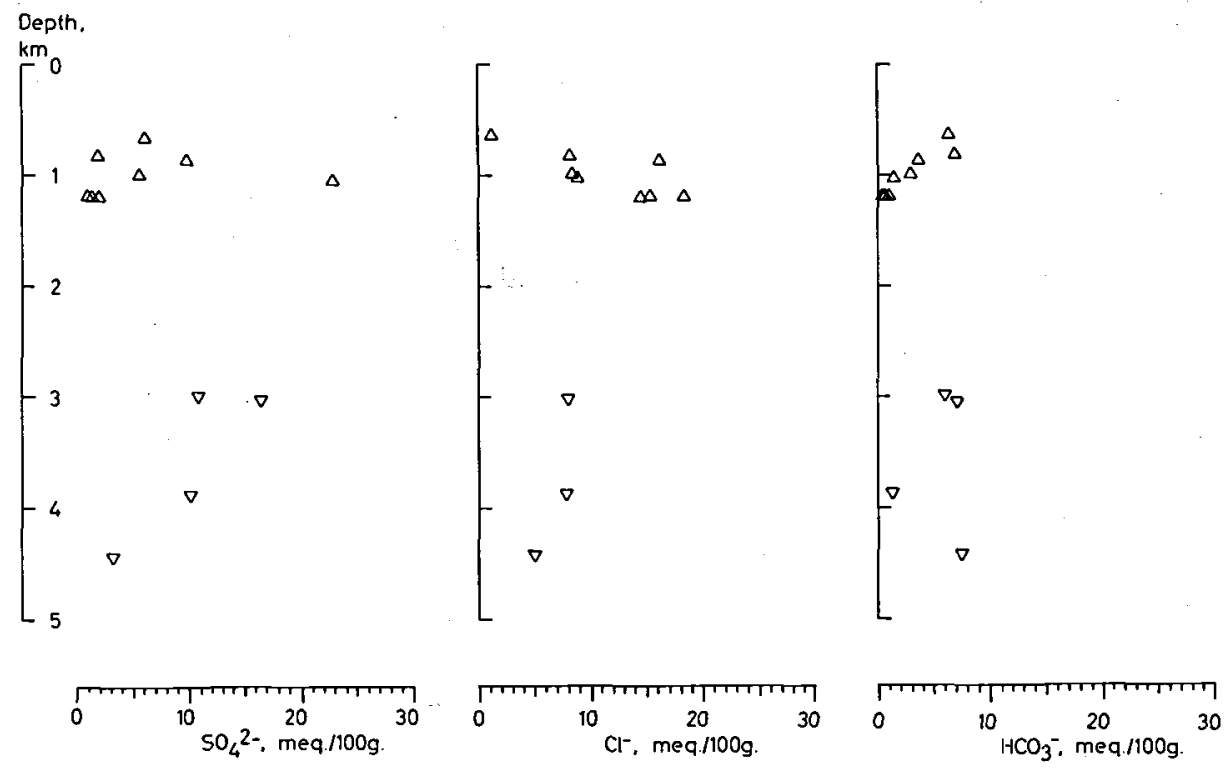

Fig. 20. Bulk rock clays from the North Sea and onshore Denmark. Amount of soluble ions in core material vs. depth of samples.

corded by XRD as illite. When illite is the major component, IS ordering, ISI ordering and ISII ordering require that smectite layers are separated by at least one, two and three illite layers, respectively. According to the interparticle diffraction concept, IS, ISI and ISII ordering require that only particles at least $20 \AA, 30 \AA$ and
$40 \AA$ thick, respectively, are found in the illite/ smectite. This contrasts with the finding of about $15 \% 10 \AA$ thick particles and about $30 \% 20 \AA$ thick particles in the ISII ordered illite/smectite from $2 / 7-3,3789 \mathrm{~m}$. The discrepancy could be due to collapse of some interparticle spacings to $10 \AA$ in $\mathrm{Mg}$-glycolated specimens, but could also be 
due to misinterpretation of the ordering degree from XRD. This last possibility is probable because Reynolds (1984) mentioned that computer simulations using R3 ordering and Markov theory give good agreement with experimental patterns with next-to-next neighbour ordering, but that the agreement anyway is not as good as for less distant ordering. Correspondingly, Altaner \& Bethke (1988) found that TEM on shadowed dispersed specimens indicated lower $P_{I}$ values than the simulated XRD patterns did.

The three, randomly ordered or I-S segregated illite/smectites are either dominated by $10 \AA$ thick particles $(2 / 7-3,3365 \mathrm{~m}$; M8, $2368 \mathrm{~m})$ or have a large amount of particles of different thicknesses (fig. 17), both of which after the interparticle concept of Nadeau et al. (1984) should give random ordering or I-S segregation in XRD. The predominantly IS ordered sample $2 / 11-1$, $4548 \mathrm{~m}$, is composed mainly of particles with a uniform thickness distribution, from $20 \AA$ to $60 \AA$ (fig. 17), where IS ordering according to the interparticle diffraction idea should be due to predominance of $20 \AA$ thick particles. However, HRTEM on the dispersed samples showed that $20 \AA$ period particles, most probably IS ordered MacEwan illite/smectite particles as discussed above, are abundant in this and other IS ordered illite/smectite fractions (an example is shown in fig. $16 \mathrm{~b}$ and $16 \mathrm{c}$ ). Therefore the particles seen in shadowed TEM are not all illite particles and complete dispersion of the smectite layers has accordingly not been achieved. Assuming that all $40 \AA$ and $60 \AA$ thick particles seen in TEM of shadowed specimens are IS ordered illite/smectite particles leads to a fraction of illite layers for $2 / 11-1,4548 \mathrm{~m}$, of 0.79 . This agrees, as does the value from TEM given in table 7 , with the $P_{I}$ value from $X R D$ and illustrates that a fair agreement between XRD and TEM values can not be taken as proof for the occurrence of only "fundamental" illite particles in a sample. It should be noted that even those particles showing only $10 \AA$ period in contrast in HRTEM images (like those in fig. 16a) may well contain smectite layers. This is because near-perfect orientation of the particles is required for observation of periodically enhanced contrast (Guthrie \& Veblen 1989 and 1990) and such near-perfect contrast is difficult to achieve in the loosely sedimented particles viewed edge-on.

\section{Illite/smectite diagenesis}

\section{Illitization of illite/smectite during burial diagenesis}

The conclusion of the literature review on illitization of illite/smectite was that smectite layers are converted to illite layers during burial diagenesis. The conversion is initiated above $55^{\circ} \mathrm{C}$, and the illite/smectite becomes IS ordered at about $100^{\circ} \mathrm{C}$ when it contains about $80 \%$ illite layers.

Diagenesis of the Upper Jurassic illite/smectite of the present investigation was discussed by Hansen \& Lindgreen (1989). For Central Trough samples, a plot of $P_{I}$ and ordering values versus temperature is shown in fig. 18 . The present day temperatures of the samples were derived from the calculated formation temperature gradients of Evans \& Coleman (1974) and Jensen (1982). Scattering of the points is considerable, probably to a large degree because of uncertainties in the calculated formation temperatures. Ordering in illite/smectite begins at about $90^{\circ} \mathrm{C}$ and randomly ordered or I-S segregated illite/smectite is absent above $115^{\circ} \mathrm{C}$. Three samples, from wells $\mathrm{W} 1$ $(3816 \mathrm{~m})$ and $2 / 7-3(3365 \mathrm{~m}$ and $3502 \mathrm{~m})$ deviate from the general trend (see below). For the other samples, correlation between temperature and $P_{I}$ is low (0.69) and ordering in illite/smectite accompanied by an increase in $P_{1}$ from $0.65-0.75$ for randomly ordered or I-S segregated illite/ smectite to $0.80-0.95$ for ordered illite/smectite was the most obvious response of the illite/smectite to increasing temperature. The ordering temperature interval, $90-115^{\circ} \mathrm{C}$, agrees well with the ordering temperature of 1) $95^{\circ} \mathrm{C}$ for an Oligocene-Miocene Texas Gulf Coast well (Hower et al. 1976); 2) $115-125^{\circ} \mathrm{C}$ for the Miocene-Pliocene Texas Gulf Coast well E (Perry \& Hower 1970), which has a high geothermal gradient $\left(30.5^{\circ} \mathrm{C} / \mathrm{km}\right)$; and 3) $99^{\circ} \mathrm{C}$ for the Lower Cretaceous shales of the Rocky Mountain area, which have an even higher geothermal gradient of $41^{\circ} \mathrm{C}$ (Burtner \& Warner 1986). But it is lower than the $130-160^{\circ} \mathrm{C}$ for the Miocene Pliocene well $\mathrm{C}$ with a low geothermal gradient $\left(24.0^{\circ} \mathrm{C} / \mathrm{km}\right)$ (Perry \& Hower 1970).

The samples from the Norwegian-Danish Basin contain randomly ordered or I-S segregated illite/smectite with $P_{I} 0.65-0.75$ at formation temperatures of $24-68^{\circ} \mathrm{C}$. This extends then the tem- 


\section{$\mathrm{NH}_{4} 1 \mathrm{KK}$ molar ratios vs. depth}

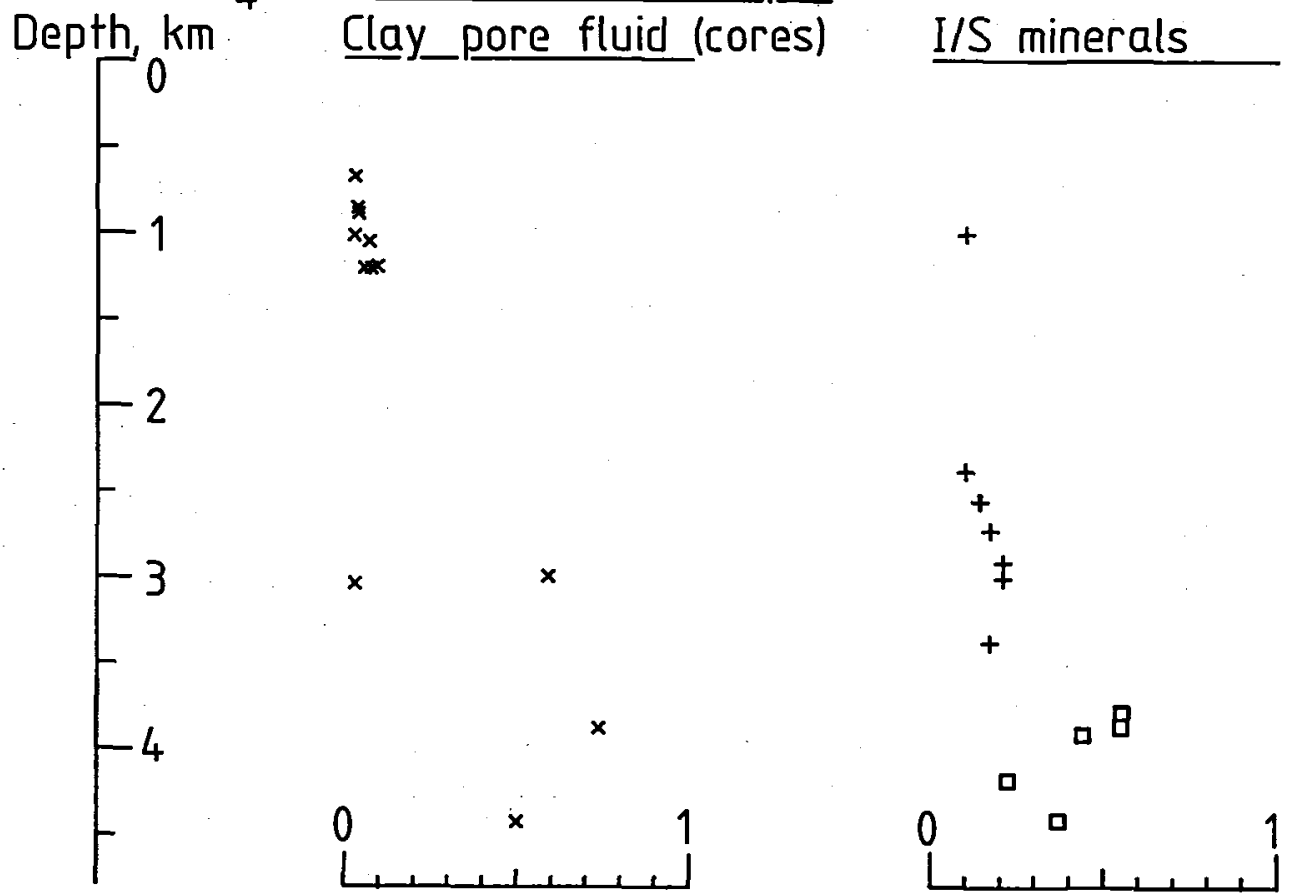

Fig. 21. Bulk rock clays from the North Sea and onshore Denmark. $\mathrm{NH}_{4} / \mathrm{K}$ molar ratios in core pore fluids and in illite/smectite fractions vs. depth. $(+)=$ randomly ordered or I-S segregated, and $(\square)=$ IS ordered illite/smectite (I/S).

perature range for these illite/smectites down to $24^{\circ} \mathrm{C}$, far below the $55^{\circ} \mathrm{C}$ required for illite layer formation and the c. $70^{\circ} \mathrm{C}$ found by Perry \& Hower (1970) to be required for formation of illite/smectite with a similar amount of illite layers. These illite/smectites must therefore be detrital in the Norwegian-Danish Basin. This conclusion, together with their occurrence in the Central Trough wells at temperatures ranging from $80^{\circ} \mathrm{C}$ to $90-115^{\circ} \mathrm{C}$, makes it likely that they are also detrital in the Central Trough, even if they could have formed at the temperatures in the Central Trough according to the data of Perry \& Hower (1970).

Besides temperature several investigations (e.g. Eberl \& Hower 1976; Ramseyer \& Boles 1986) have shown the importance of time to the illitization process. Vitrinite reflectancy is also a result of both time and temperature and it is the standard parameter in source rock maturation evaluations. Because it has been shown that illite/ smectite react slower to heating than do vitrinite (Heling \& Teichmüller 1974; see literature review), the comparison of illitization in illite/smectite with vitrinite reflectancy will show an eventu- al influence of long-lived paleothermal events. Vitrinite reflectancy values, $R_{0}$, are available for wells E1, M8, U1 and I1 (down to $3885 \mathrm{~m}$ ) from Thomsen et al. (1983) and for well 2/11-1 from Thomsen (1984), but not from G1, W1 and 2/7-3. Vitrinite reflectancy values from Danish onshore wells are available from Thomsen et al. (1983) and Schmidt (1985). A plot of $P_{I}$ versus $R_{0}$ is shown in fig. 19. The immature onshore well sections from the Danish Subbasin all contain randomly ordered or I-S segregated illite/smectite. In the Central Trough, the plotted randomly ordered or I-S segregated mixed-layers are only found in the interval $0.60-0.67 \%$ for $R_{0}$, whereas IS and ISII ordered mixed-layers are found above $R_{o}$ values of $0.63 \%$. A regression analysis for the IS and ISII ordered mixed-layers shows that $P_{I}$ is not increasing significantly with $R_{o}$, and that the correlation coefficent is 0.26 . Vitrinite reflectancy values were not available for the three samples deviating in the $P_{I}-T$ plot in fig. 18. The plot of $P_{I}$ and ordering in illite/smectite vs. vitrinite reflectancy thus confirmed the finding from the plot of $P_{I}$ and ordering vs. present temperature, i.e. that the randomly ordered or I-S segre- 
gated illite/smectite with $P_{1} 0.65-0.75$ become ordered in response to an increase in temperature, which is reflected in an increase in vitrinite reflectancy also. Furthermore, the finding of randomly ordered or I-S segregated illite/smectite with $\mathbf{P}_{\mathbf{I}}$ $0.65-0.75$ at vitrinite reflectancies down to 0.4 shows that these illite/smectites have not formed during paleoheating events, especially because vitrinites react faster to short-lived heating events than do illite/smectite (Środoń 1979; Smart \& Clayton 1985). These illite/smectites must therefore be detrital.

\section{Parent material for illite/smectite}

The source for the illite/smectite of the present investigation was discussed by Hansen \& Lindgreen (1989). Pearson et al. (1982) proposed that randomly ordered or I-S segregated illite/smectite in Viking Graben wells at vitrinite reflectancies lower than 0.60 were detrital and Hurst (1982) proposed a detrital origin (in this case from the northern part of Scotland) for randomly ordered or I-S segregated illite/smectite in Jurassic shales from Brora, NE Scotland, with "in general" $35-60 \%$ illite layers. This fits well with the conclusion above that the parent material for illite/smectite diagenesis (except for illite/smectite in wells $\mathrm{W} 1(3816 \mathrm{~m})$ and $2 /-3$ (3365 $\mathrm{m}$ and $3502 \mathrm{~m}$ )) in the Central Trough and the Norwegian-Danish Basin is randomly ordered or I-S segregated illite/smectite. On the other hand, Hurst (1982) also found ordered illite/smectite in the same area, but he related it to Devonian sandstone as parent rock. Both ordered and randomly ordered illite/smectite may form during weathering in soils (Eberl 1984). In the present investigation the detrital illite/smectite with $P_{I}$ $0.65-0.75$ originate probably from weathered material on the highs, notable the Fennoscandian Shield, conforming with the arguments of Sladen \& Sellwood and with the conclusion on origin of discrete clay minerals in the coarse clay fraction, see above.

The three illite/smectites deviating from the general $P_{\Gamma}-T$ trend in fig. 18, from wells W1 (3816 $\mathrm{m})$ and $2 / 7-3(3365 \mathrm{~m}$ and $3502 \mathrm{~m})$ are from samples which contain large amounts of these mixed-layers, such that the mixed-layers are also found in aggregates in the other clay subfractions and in the sand and silt fraction. According to
Lindgreen et al. (1991), the detrital randomly ordered or I-S segregated illite/smectites and the IS and ISII ordered illite/smectite follow the same trend in chemical composition with $P_{1}$, whereas the I/S from $2 / 7-3,3365 \mathrm{~m}$ (the only one of these three samples investigated for all elements) deviated significantly from this trend in containing less $\mathrm{Mg}$ and $\mathrm{Fe}$ and more $\mathrm{Al}$ and in having more tetrahedral $\mathrm{Al}$. The three mixedlayer clays are therefore assumed to have a particular parent material, very rich in smectite. This is probably a bentonite, which is a rock dominated by smectite (Grim \& Güven 1978). Bentonites usually originate from volcanic ash (Grim \& Güven 1978), they show lower $P_{1}$ values than surrounding shales (Hoffman \& Hower 1979; Srodon 1979) and they have, at a given temperature, low $\mathrm{P}_{1}$ values compared to detrital illite/ smectite (Velde \& Brusewitz 1986). The hypothesis of a bentonitic and possibly volcanic origin explains the drastic change in well $2 / 7-3$ from a $P_{I}$ value of 0.40 and random ordering or I-S segregation at $3502 \mathrm{~m}$ to a $P_{I}$ value of 0.95 and ISII ordering at $3789 \mathrm{~m}$, and in well $\mathrm{W} 1$ from a $P_{I}$ value of 0.50 and I-S segregation at $3816 \mathrm{~m}$ to a $P_{1}$ value of 0.80 and IS ordering at $4051 \mathrm{~m}$. The interpretation agrees with the reported volcanic activity in the region (see literature review). It is furthermore supported by the results of Pearson \& Small (1988). They found that the mineralogical variation in fine fractions of Quaternary to Triassic shales from the Viking Graben and the Moray Firth exhibited a strong source control and attributed particularly the very high abundance of randomly ordered or I-S segregated illite/smectite to alteration of volcanic ash.

\section{Chemical controls}

Cores from the Børglum Formation in the Danish Subbasin (wells Børglum 1, Frederikshavn 1, Gassum 1, Haldager 1 and Uglev 1) and from the Farsund Formation in the Central Trough (wells 2/11-1, E1, Jens 1 and Elin 1) were investigated. Cleaned core samples were crushed to pass a 0.25 $\mathrm{mm}$ sieve and two samples were washed four times with $1 \mathrm{M} \mathrm{MgCl}$ and $0.5 \mathrm{M} \mathrm{RbNO}$, respectively. The $\mathrm{pH}$ was $\sim 6$ in the extracts from Gassum $1, \sim 7$ in the extracts from $2 / 11-1,3877 \mathrm{~m}$ and from Haldager $1,1049 \mathrm{~m}$ and $\sim 8$ in the extracts from the other core samples. It is prob- 


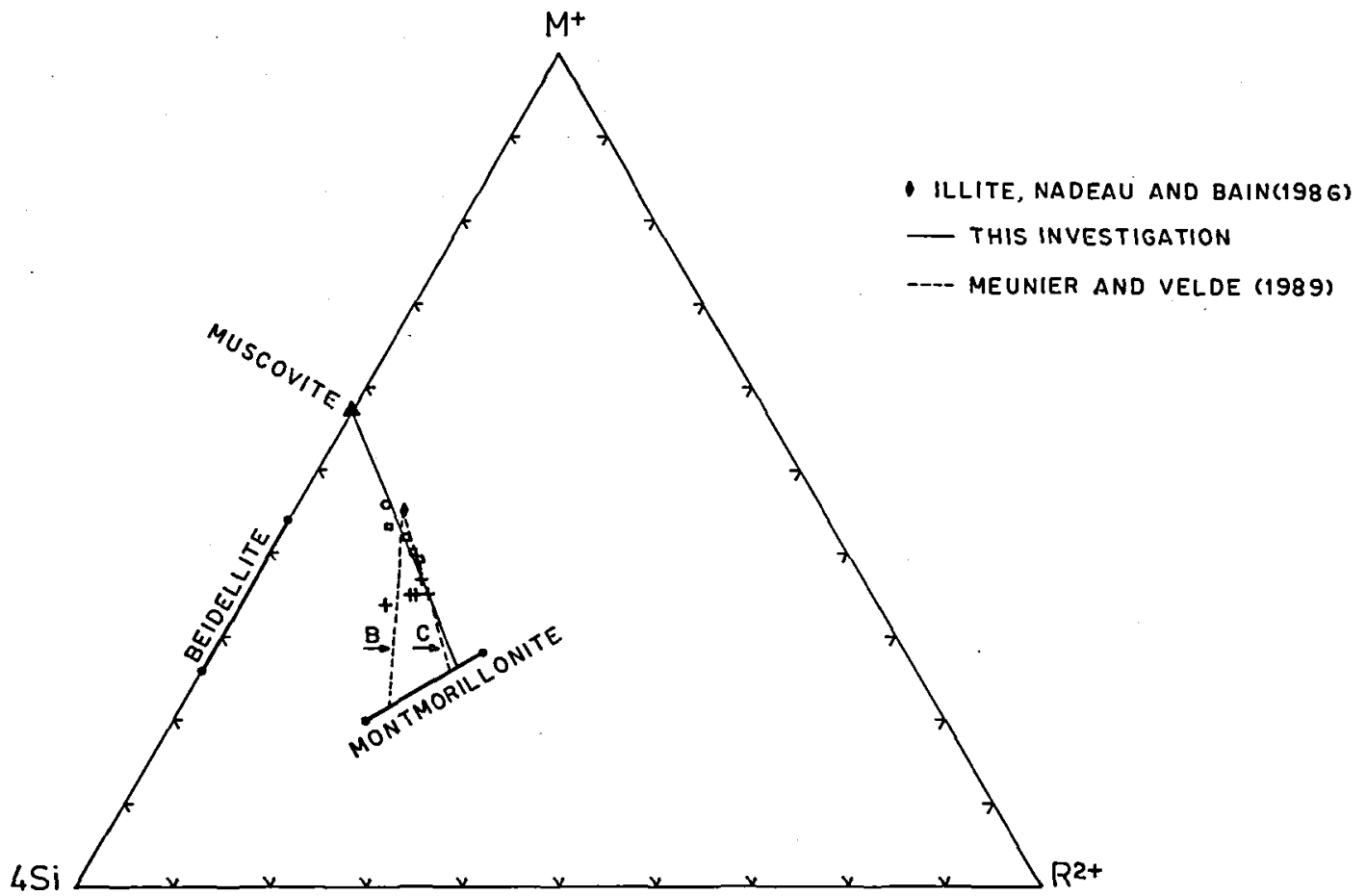

Fig. 22. Illite/smectite from the Central Trough plotted in a ternary $M^{+}-4 S i-R^{2+}$ system used by Meunier \& Velde (1989). $M^{+}$is equivalent of fixed plus adsorbed interlayer cations, $4 \mathrm{Si}$ is the number of silicon atoms, $\mathrm{R}^{2+}$ is the number of divalent octahedral cations, all per $\mathrm{O}_{10}(\mathrm{OH})_{2}$. The three coordinates are: 1$\left.): \mathbf{M}^{+}: \mathbf{M}^{+} /\left(\mathrm{M}^{+}+\mathrm{Si}+\mathrm{R}^{2+}\right) ; 2\right): 4 \mathrm{Si}: \mathrm{Si} /\left(\mathrm{M}^{+}+\mathrm{Si}+\mathrm{R}^{2+}\right) ;$ and 3$): \mathrm{R}^{2+}: \mathrm{R}^{2+} /$ $\left(\mathrm{M}^{+}+\mathrm{Si}+\mathrm{R}^{2+}\right)$; it should be noted that $\mathrm{Si}$ is one fourth of the number of tetrahedral silicon atoms per $\mathrm{O}_{10}(\mathrm{OH})_{2} \cdot(+)=\mathrm{randomly}$ ordered or I-S segregated, $(\square)=$ IS ordered, and $(O)=$ ISII ordered illite/smectite.

able that some $\mathrm{NH}_{3}$ has escaped from the core fluids with $\mathrm{pH} 8$ and that the $\mathrm{NH}_{4}$ values determined are lower than in the formations sampled, even if the content of $\mathrm{NH}_{4}$ was determined the day after the extraction and the maximum $\mathrm{NH}_{4}$ concentration in the extracts was $2 \mathrm{ppm}$. The contents of soluble + exchangeable cations are shown in fig. 20. The dominating cations are $\mathrm{Na}^{+}$ and $\mathrm{Ca}^{2+}$, there are minor amounts of $\mathrm{Mg}^{2+}$, and very small amounts of $\mathrm{K}^{+}$and $\mathrm{NH}_{4}{ }^{+}$. An exception is Jens $1,3034 \mathrm{~m}$, where $\mathrm{K}^{+}$is present in relatively large amounts. The contents of $\mathrm{Mg}^{2+}$ and $\mathrm{K}^{+}$do not change with depth. The content of $\mathrm{Na}^{+}$is low in the most shallow core from Frederikshavn $1,649 \mathrm{~m}$, but decreases for the other samples with depth. The content of $\mathrm{NH}_{4}{ }^{+}$is relatively high in three deep samples: Elin 1, $4418 \mathrm{~m}$; $\mathrm{E} 1,2983 \mathrm{~m}$; and $2 / 11-1,3877 \mathrm{~m}$, but is lower in Jens $1,3034 \mathrm{~m}$ and in samples from less than 1500 $\mathrm{m}$ depth. The $\mathrm{Cl}^{-}, \mathrm{HCO}_{3}{ }^{-}$and $\mathrm{SO}_{4}{ }^{2-}$ anions are present in varying amounts in the samples (fig. 20). They do not vary in amount with depth even though three deep samples: E1, $2983 \mathrm{~m} ; 2 / 11-1$,
$3877 \mathrm{~m}$; and Jens 1, $3034 \mathrm{~m}$, have a high content of sulphate.

Weaver \& Beck (1971) and Schmidt (1973) found that $\mathrm{Na}^{+}$is the dominating cation in pore waters from the US Gulf Coast shales, $\mathrm{K}^{+}, \mathrm{Mg}^{2+}$ and $\mathrm{Ca}^{2+}$ being of minor importance. This predominance of $\mathrm{Na}^{+}$was also observed by Jones, Hughes \& Tomkins (1989) for Lower Cretaceous shales from the Witch Graben of the North Sea. The addition of pore water cations and exchangeable cations in the present investigation cannot account for the high amounts of $\mathrm{Ca}^{2+}$ relative to $\mathrm{Na}^{+}$in the present investigation, even if $\mathrm{Ca}^{2+}$ (because of its divalent charge) is adsorbed on the exchange sites preferentially to $\mathrm{Na}^{+}$. Gypsum was detected in several samples (tables $5 \mathrm{a}$ and $\mathrm{b}$ ) and the solubility product for $\mathrm{CaCO}_{3}$ is exceeded by dissolved $\mathrm{Ca}^{2+}$ and $\mathrm{HCO}_{3}^{-}$. Thus the relatively high amounts of $\mathrm{Ca}^{2+}$ in the present investigation are due to dissolution of calcite and gypsum during laboratory leaching. In US Gulf Coast shales, Weaver \& Beck (1971) found that $\mathrm{HCO}_{3}^{-}$generally was the dominating anion, 


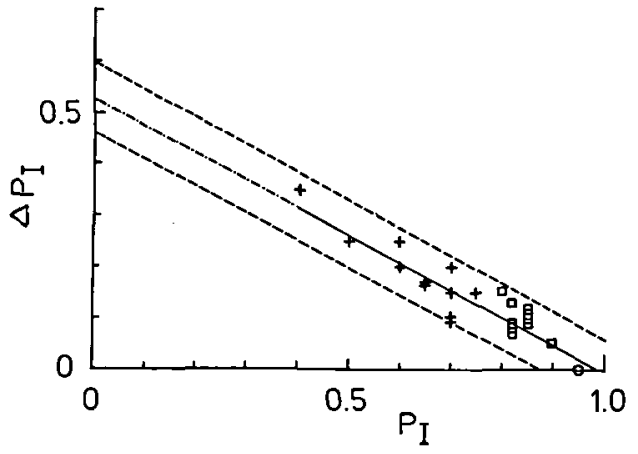

Fig. 23. Illite/smectite from the Central Trough. $\Delta \mathbf{P}_{\mathbf{I}}$ vs. $\mathbf{P}_{\mathbf{I}} \cdot \Delta$ $P_{I}$ is the fraction of all illite/smectite which is smectite but remains contracted to $10 \AA$ after $\mathrm{K}^{+}$- saturation and glycolation. $(+)=$ randomly ordered or I-S segregated, $(\square)=$ IS ordered, and $(\mathrm{O})=$ ISII ordered illite/smectite. From Lindgreen et al. (1991, fig. 9).

$\mathrm{SO}_{4}{ }^{2-}$ next in abundance, followed by $\mathrm{Cl}^{-}$, whereas Schmidt (1973) found that $\mathrm{SO}_{4}{ }^{2-}$ generally was dominating, $\mathrm{HCO}_{3}^{-}$next, followed by $\mathrm{Cl}^{-}$. In North Sea Cretaceous shales, Jones et al. (1989) found that $\mathrm{Cl}^{-}$was dominating, $\mathrm{CO}_{3}{ }^{2-}$ next, followed by $\mathrm{SO}_{4}{ }^{2-}$. The general dominance of $\mathrm{SO}_{4}{ }^{2-}$ over $\mathrm{Cl}^{-}$and $\mathrm{HCO}_{3}{ }^{-}$in the present investigation is thus in accordance with the results for the shales investigated by Schmidt but disagrees with the data of Weaver \& Beck and especially the data of Jones et al. (1989). Weaver \& Beck (1971) reported their data in ppm, but a correction for equivalent weight does not change the relative abundances of either cations or anions by more than a factor two.

The contents of sodium and chloride are both markedly high in the four shallow samples from the wells Gassum 1, 1190 and $1191 \mathrm{~m}$ ( 3 samples) and Uglev 1, $862 \mathrm{~m}$ (fig. 20). These two wells are the only onshore wells drilled on salt structures and the high contents of sodium and chloride must be due to salt solutions migrating upwards from the Zechstein, in Gassum 1 through Triassic sandstone $(700 \mathrm{~m})$ and shale $(1200 \mathrm{~m})$ and Lower Jurassic clays $(300 \mathrm{~m})$, and in Uglev 1 through Middle Jurassic sandstone $(60 \mathrm{~m})$ (both wells are drilled on top of the structures). Of the Central Trough wells for which pore water chemistry has been investigated, only one (2/11-1) is drilled on a possible Zechstein salt structure, but salt water from the Zechstein has not infiltrated the Upper Jurassic claystones in this well to any measurable extent. Cayley (1987) mentioned that produced formation waters from the Tertiary sandstones in the Central Trough are salt saturated and that this indicates that waters associated with the Zechstein have migrated vertically. Schmidt (1973) found a constant amount of exchangeable potassium and an increasing amount of potassium in interstitial water of shale with depth. He explained the increasing amount in interstitial water to be the result of breakdown of detrital feldspar, and the constant amount of exchangeable potassium to be due to potassium fixation in interlayer positions of illite. Potassium feldspars could not be detected in the sand and silt fraction of the North Sea claystones. This may explain the lack of variation of potassium with depth in this investigation. Bogomolov, Kudel'skiy \& Kozlov (1970) analysed groundwaters in various oil and gas basins in USSR and found that ammonium is a direct indicator of a present or past occurrence of oil below the surface. They attributed this to ammonium being one of the conversion products of oil. A similar origin can explain the high content of ammonium in the oil generating Central Trough claystones rich in organic material compared to the immature onshore claystones with less organic material or a more terrestrial origin.

The absence of potassium feldspars in samples from the Central Trough indicates that the potassium for illite layer formation must be supplied by pore water migrating from deeper layers (as proposed by Long \& Neglia (1968), Weaver \& Beck (1971), and by Hay, Lee, Kolata, Matthews \& Morton (1988)) or from breakdown of detrital mica (as proposed by Hower et al. (1976)). Both processes should give an increase in the amount of pore water potassium with depth. The constant amount of potassium in pore waters in the present investigation must be due to the fact that the supply of potassium is small compared to the fixation in illite/smectite. Long \& Neglia (1968) found that illite/smectite diagenesis is influenced by pore water chemistry. In the present investigation the parallelism is obvious between 1: the $\mathrm{NH}_{4}{ }^{+} / \mathrm{K}^{+}$ratio in pore waters vs. depth and 2: the $\mathrm{NH}_{4}{ }^{+} / \mathrm{K}^{+}$ratio in illite/smectite vs. depth (fig. 21). This shows that the $\mathrm{NH}_{4}^{+} / \mathrm{K}^{+}$ratio in pore water controls the fixation of $\mathrm{NH}_{4}{ }^{+}$and $\mathrm{K}^{+}$in illite/smectite during diagenetic illite layer formation and illite/smectite ordering in our samples. 


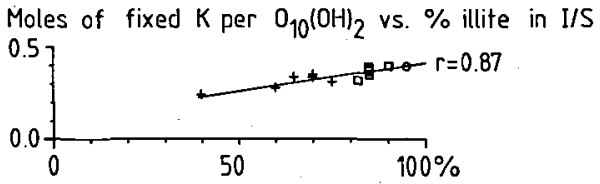

Moles of fixed $\mathrm{NH}_{4}$ per $\mathrm{O}_{10}(\mathrm{OH})_{2}$ vs. \% illite in I/S

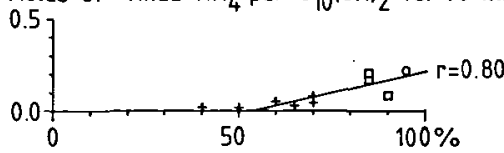

Fig. 24. Illite/smectite from the Central Trough. Moles of fixed $\mathrm{K}$ (a) and fixed $\mathrm{NH}_{4}$ (b) per $\mathrm{O}_{10}(\mathrm{OH})_{2}$ vs. \% illite in illite/ smectite (equal to $100{ }^{{ }^{\mathrm{P}} \mathrm{I}}$ ). $(+)=$ randomly ordered or I S segregated, $(\square)=$ IS ordered and $(O)=$ ISII ordered illite/ smectite (I/S).

\section{Elemental composition of illite/smectite}

Fine-clay fractions $(<0.2 \mu \mathrm{m})$ of the Upper Jurassic claystones were investigated by ${ }^{27} \mathrm{Al}$ and ${ }^{29}$ Si MAS NMR spectroscopy by Jakobsen, Jacobsen \& Lindgreen (1988).

For the Upper Jurassic illite/smectites, structural arrangements of major elements (Fe, Al and $\mathrm{Si}$ ) were investigated by ${ }^{57} \mathrm{Fe}$ Mössbauer spectroscopy, by ${ }^{27} \mathrm{Al}$ and ${ }^{29} \mathrm{Si}$ MAS NMR spectroscopy and by infrared (IR) spectroscopy (Lindgreen et al. 1991). For details of IR spectroscopy, see App. 1. Furthermore, the elemental composition of the illite/smectite fraction was determined by total dissolution ( $\mathrm{HF}-\mathrm{H}_{3} \mathrm{BO}_{3}$ ) followed by atomic absorption spectrometry (AAS) of dissolved elements. $\mathrm{NH}_{4}$ was determined by degassing at $600^{\circ} \mathrm{C}$ and isotope dilution. From these data, the diagenetic structure transformations were discussed by Lindgreen et al. (1991).

\section{Lattices of illite and smectite layers}

The composition of illite/smectite at $\mathrm{P}_{\mathrm{I}} \mathbf{1 . 0}$ was calculated by prolongation of the lines of elemental composition vs. $P_{1}$, of $\mathrm{Al}(4) / \mathrm{Al}(6)$ vs. $P_{I}$, of $\mathrm{Al}(4) /(\mathrm{Al}(4)+\mathrm{Si})$ vs. $\mathrm{P}_{\mathrm{I}}$ (Lindgreen et al. 1991), and of $\mathrm{Fe}^{2+} / \mathrm{Fe}^{3+}$ vs. $\mathrm{P}_{\mathrm{I}}$. The corresponding formula is:

$$
\begin{aligned}
& \mathrm{Na}_{0.45} \mathrm{~K}_{0.42}\left(\mathrm{NH}_{4}\right)_{0.22} \\
& \left(\mathrm{Mg}_{0.13} \mathrm{Al}_{1.67} \mathrm{Fe}^{2+}{ }_{0.04} \mathrm{Fe}^{3+}{ }_{0.12}\right)\left(\mathrm{Al}_{0.68} \mathrm{Si}_{3.32}\right) \mathrm{O}_{10}(\mathrm{OH})_{2}
\end{aligned}
$$

and this may therefore be the composition of illite layers in illite/smectite. Prolongation of the lines to $P_{1} 0$ would then give the composition of the smectite layers, but such a prolongation is not justified as the data are only statistically reliable above $\mathrm{P}_{\mathrm{I}} 0.6$, also because $\mathrm{NH}_{4}{ }^{+}$vs. $\mathrm{P}_{\mathrm{I}}$ and $\mathrm{Al}(4) /$ $(\mathrm{Al}(4)+\mathrm{Si})$ vs. $\mathrm{P}_{\mathrm{I}}$ cannot be extrapolated below $P_{I} \cdot 0.55$. The calculated illite layer composition shows the same, small content of $\mathrm{Mg}$ and $\mathrm{Fe}$ in the octahedral sheet. This and the tetrahedral Al content of 0.68 is normal for illites (Weaver \& Pollard 1973, table V).

Meunier \& Velde (1989) plotted previously published chemical data on illite/smectite in a $4 \mathrm{Si}-\mathrm{M}^{+}-\mathrm{R}^{2+}$ triangular diagram, where $\mathrm{M}^{+}$and $\mathrm{R}^{2+}$ are the layer charge and the number of divalent, octahedral cations, respectively. They noted that Cretaceous and Tertiary samples were characterized by a strong dispersion of chemical compositions bounded by ideal beidellite (having only tetrahedral substitutions) and ideal montmorillonite (having only octahedral substitutions). The Silurian and Ordovician samples showed on the contrary a linear relationship between illite and montmorillonite components. For these samples, the lines joined an illite/smectite component having a constant layer charge of -0.75 with montmorillonites having an octahedral sheet charge between -0.33 and -0.66 . This smectite layer charge was lowest in bentonites from Poland and highest in bentonites from Sweden. The chemical composition of illite/smectite from the Upper Jurassic of this investigation are similarly plotted in fig. 22 . They fall on a line between muscovite and a montmorillonite with an octahedral sheet charge of 0.54 , i.e. a highcharge montmorillonite. This line is close to the one for the samples from the United Kingdom plotted in Meunier \& Velde's fig. 2C (line $\mathrm{C}$ in fig. 22). The illite/smectite of probably volcanic origin and for which chemical composition was determined plots away from this line and slightly to the left of the line shown in Meunier \& Velde's fig. 2B (line B in fig. 22) for Silurian bentonites from Poland. The illite/smectite from $2 / 7-3,3789$ $\mathrm{m}$, with $95 \%$ illite layers and ISII ordering, plots closer to muscovite than does the end-member of Meunier and Velde, a Rotliegende sandstone reservoir illite from the North Sea. Meunier \& Velde attributed the determinations by several authors of $0 \%$ expandable layers at values below -0.87 layer charge to incorrect estimations from $\mathrm{X}$-ray diffractograms. In this respect the illite/ 


\section{MODELS FOR MIXED-LAYERING IN I/S}

$\begin{array}{llll}\text { XRD } & \text { Marcovian } & \text { dispersed } & \text { fundamental } \\ \text { spacings model } & \text { MacEwan } & \text { particle } \\ & \text { MacEwan } & \text { particle } & \text { model }\end{array}$

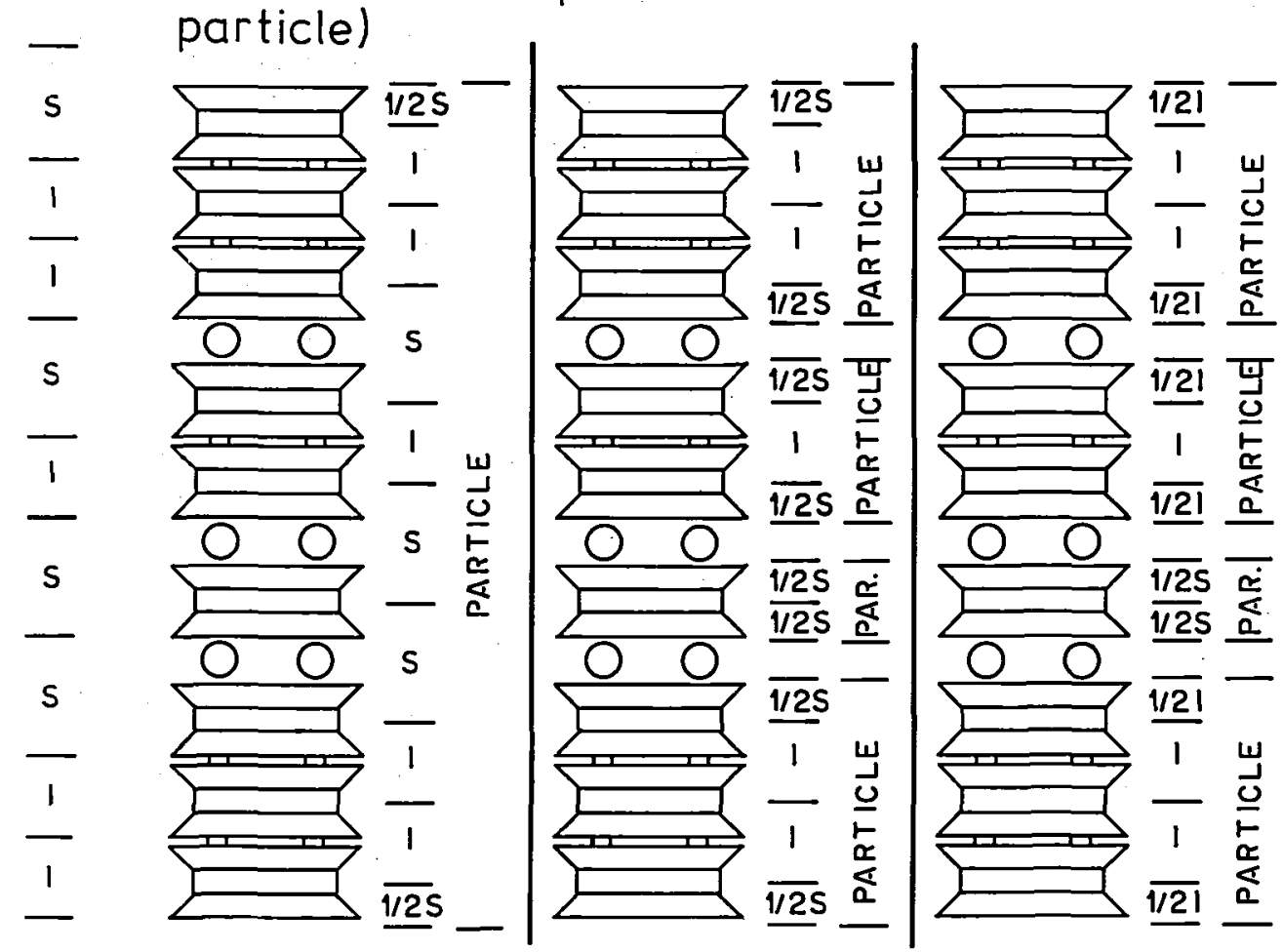

\footnotetext{
乙: TETRAHEDRAL SHEET

$\square$ : OCTAHEDRAL SHEET

口: FIXED INTERLAYER CATION

O: ADSORBED AND EVENTUALLY HYDRATED INTERLAYER CATION

$S$ : SMECTITE

1 : ILLITE

1/2S: $1 / 2$ 2:1 LAYER WITH SMECTITIC SUBSTITUTION

1/21: 1/2 2:1 LAYER WITH ILLITIC SUBSTITUTION
}

Fig. 25. Models for mixed-layering in illite/smectite and implications for composition of particle terminating layers. Model for randomly ordered illite/smectite with $\mathrm{P}_{\mathrm{I}} 0.8$ (or with $80 \%$ illite layers).

smectite from $2 / 7-3,3789 \mathrm{~m}$, with a layer charge of -0.85 and $5 \%$ illite layers, is closer to the expectations of Meunier \& Velde. The discrepancies between the amount of expandable layers predicted by the plots of Meunier \& Velde on the one hand and the expandabilities calculated from
$\mathrm{X}$-ray diffractograms on the other hand are more likely to be due to the fact that Meunier \& Velde plot ideal layer compositions, whereas natural illite/smectites probably contain illite sites in smectite layers and smectite sites in illite layers. 
Elemental changes in illite/smectite during diagenesis

It was concluded in the literature review that $\mathrm{Al}^{3+}$ substitutes for $\mathrm{Si}^{4+}$ and that $\mathrm{K}^{+}$is fixed during the diagenetic formation of illite layers. Some of the investigations also found substitution of $\mathrm{Al}^{3+}$ for $\mathrm{Fe}$ and $\mathrm{Mg}$ in the octahedral sheet and reduction of $\mathrm{Fe}^{3+}$. In most of these investigations, however, the accuracy of the figures for tetrahedral $\mathrm{Al}^{3+}$ is low (because it has been calculated from tetrahedral $\mathrm{Si}$, which is about five times larger) and fixed $\mathrm{NH}_{4}^{+}$has not been determined.

Srodon et al. (1986) suggested from their investigation on diagenetic illite/smectites that illitization proceeded by a transformation mechanism in their bentonites from the Silurian of Wales, from the Carboniferous of Silesia, and from the Cretaceous of Montana. This was because their calculations showed a stable octahedral charge and stability of early formed illite layers throughout the series. The samples of Srodon et al. covered almost the whole illite/smectite compositional range, from about $10 \%$ to about $100 \%$ illite layers. The Upper Jurassic mixed-layers of the present investigation cover only the interval $40-95 \%$ illite layers. Furthermore, the three mixed-layers with $40-50 \%$ illite (of which the elemental composition was determined for only one) probably originate from bentonites, whereas the others are largely of continental origin. Therefore, only the interval between $60-95 \%$ illite layers $\left(0.60-0.95 \mathrm{P}_{\mathrm{I}}\right)$ is statistically reliable. This interval covers the randomly ordered or I-S segregated, IS and ISII ordered illite/smectite. However, the upper part of the $P_{I}$ interval for randomly ordered or I-S segregated illite/smectite, $0.6-0.75 P_{I}$, is so narrow that the trends for the randomly ordered or I-S segregated mixed-layers cannot be relied upon. The elemental composition of the mixed-layers was plotted vs. $P_{I}$ (Lindgreen et al. 1991, fig. 7). All plots were fitted with one regression line, but it cannot be excluded that two or more lines would have been more appropriate, if the whole range of $P_{I}$ values, also below $P_{I} 0.6$, had been represented in the material. Thus, for randomly ordered or I-S segregated illite/smectite, a line segment parallel to the $P_{1}$ axis will fit in most plots (exceptions are: fixed cations vs. $\mathrm{P}_{\mathrm{I}}$ and $\mathrm{SiO}_{2}$ vs. $P_{I}$ ) if the mixed-layers of bentonitic origin shall conform to a general trend for randomly ordered or I-S segregated illite/smectite. Such a trend, however, is not probable, since it means a constant $\mathrm{Al}(4) / \mathrm{Al}(6)$ ratio and a constant $\mathrm{Al}(4) /(\mathrm{Al}$ (4) $+\mathrm{Si})$ ratio for randomly ordered or I-S segregated illite/smectite and thus implies a layer charge constancy over the range $0.4-0.75 \mathrm{P}_{\mathrm{I}}$. Illite layer formation by aggradation, i.e. fixation of cations between high-charge layers, conforms with charge constancy in this interval. However, comparison between $\mathrm{K}^{+}$- saturated and glycolated specimens and $\mathrm{Mg}^{2+}$ - saturated and glycolated specimens showed that the ratio between high charge and low charge smectite layers is constant, about 1, irrespective of $P_{I}$ (fig. 23). Therefore a larger amount of high-charge layers is not present in the randomly ordered or I-S segregated illite/smectites. Accordingly the narrow interval of $0.6-0.75 P_{I}$ for randomly ordered or I-S segregated illite/smectite has been analysed statistically together with the IS and ISII ordered illite/smectite as one group. The two illite/smectites with $\mathrm{P}_{\mathrm{I}} 0.4$ and 0.5 fit, in the plots of $\mathrm{Al}(4) /$ $\mathrm{Al}(6)$ and $\mathrm{Al}(4) /(\mathrm{Al}(4)+\mathrm{Si})$ vs. $\mathrm{P}_{\mathrm{I}}$, a line through the origin and parallel to the line for the other samples. This indicate that these two samples formed from a smectite starting material with no tetrahedral Al for Si substitution and is compatible with formation from a pure smectite formed from volcanic ash (an origin for smectite proposed by Millot (1970) and by Nadeau \& Reynolds (1981b)).

Moles of fixed $\mathrm{K}^{+}$increase with $\mathrm{P}_{\mathrm{I}}$ (fig. 24), whereas CEC (here as moles of adsorbed $\mathrm{Na}^{+}$) decrease with $P_{I}$ by about the same amount. Moles of fixed $\mathrm{NH}_{4}{ }^{+}$increase with $\mathrm{P}_{\mathrm{I}}$ from $\mathrm{P}_{1} 0.55$ and the increase is then about twice the increase in moles of $\mathrm{K}^{+}$with $\mathrm{P}_{\mathrm{I}}$ (fig. 24).

The increase in $\mathrm{P}_{\mathrm{I}}$ during diagenesis (figs. 18 and 19) is thus correlated with an increase in $\mathrm{K}$, $\mathrm{NH}_{4}$ and $\mathrm{Al}$, and a decrease in $\mathrm{Fe}, \mathrm{Mg}$ and $\mathrm{Si}$ in illite/smectite. Lindgreen et al. (1991) from Mössbauer spectroscopy on 5 samples could not detect any trend in the ratio $\mathrm{Fe}^{2+} /\left(\mathrm{Fe}^{2+}+\mathrm{Fe}^{3+}\right)$ with $\mathrm{P}_{\mathrm{I}}$. Mössbauer spectroscopy on a larger number of samples (14) has later shown that the ratio $\mathrm{Fe}^{2+} /\left(\mathrm{Fe}^{2+}+\mathrm{Fe}^{3+}\right)$ increases with $\mathrm{P}_{\mathrm{I}}$, from a value of 0.15 at $P_{I}=0.6$ to a value of 0.23 at $P_{I}=$ 0.95 , but that the correlation coefficent is low (0.63). The values for elemental composition, for the amount of tetrahedral (4) and octahedral (6) 
Tab. 8. Elemental composition of illite/smectite calculated from plots in Lindgreen et al. (1991, Fig. 7).

\begin{tabular}{lcc}
\hline & $\mathrm{P}_{\mathrm{l}} 0.60$ & $\mathrm{P}_{\mathrm{I}} 1.00$ \\
\hline $\mathrm{Na}_{2} \mathrm{O}$ & $4.7 \%$ & $3.7 \%$ \\
$\mathrm{~K}_{2} \mathrm{O}$ & $3.7 \%$ & $5.3 \%$ \\
$\left(\mathrm{NH}_{4}\right)_{2} \mathrm{O}$ & $0.17 \%$ & $1.53 \%$ \\
$\mathrm{MgO}$ & $3.4 \%$ & $1.35 \%$ \\
$\mathrm{Fe}_{2} \mathrm{O}_{3}$ & $7.7 \%$ & $3.3 \%$ \\
$\mathrm{Al}_{2} \mathrm{O}_{3}$ & $23.2 \%$ & $32.2 \%$ \\
$\mathrm{SiO}_{2}$ & $57 \%$ & $54 \%$ \\
$\mathrm{Al}(4) /(\mathrm{Al}(4)+\mathrm{Si})$ & 0.059 & 0.172 \\
$\mathrm{Al}(4) / \mathrm{Al}^{2}(6)$ & 0.142 & 0.392 \\
$\mathrm{Fe}^{2+} /\left(\mathrm{Fe}^{2+}+\mathrm{Fe}^{3+}\right)$ & 0.149 & 0.244 \\
\hline
\end{tabular}

$\mathrm{Al}$, and for $\mathrm{Fe}^{2+}$ and $\mathrm{Fe}^{3+}$ have been calculated at $P_{I} 0.60$ and 1.00 from the data given by Lindgreen et al. (1991) and from the data for the $\mathrm{Fe}^{2+} /\left(\mathrm{Fe}^{2+}+\mathrm{Fe}^{3+}\right)$ ratio given above and are shown in table 8 . The content of $\mathrm{CaO}$ is low (average $0.23 \%$ ) and does not vary with $P_{1}$.

Full formulae were calculated from these figures for a tetrahedral lattice cation number of 4 (corresponding to $\mathrm{O}_{10}(\mathrm{OH})_{2}$ and 2 octahedral cations). This calculation, the method of fixed cationic numbers (Grim \& Güven 1978), resulted in reasonably well correspondance between the increase in net negative charge and the increase in interlayer cations (Lindgreen et al. 1991). The figures for total octahedral cations were calculated from the ideal number of octahedral cations (2) but then corrected according to nmr. This means that the accuracy relies on ${ }^{29} \mathrm{Si}$ and ${ }^{27} \mathrm{Al}$ $\mathrm{nmr}$ data. The figures from $\mathrm{nmr}$ and the content of $\mathrm{Al}_{2} \mathrm{O}_{3}$ and $\mathrm{SiO}_{2}$ fit into the same formula for $\mathrm{P}_{\mathrm{I}}$ 1.00. At $\mathrm{P}_{\mathrm{I}} 0.60$, the content of $\mathrm{Al}_{2} \mathrm{O}_{3}$ and the nmr data from ${ }^{29} \mathrm{Si}$ and ${ }^{27} \mathrm{Al} \mathrm{nmr}$ correspond well, whereas the content of $\mathrm{Si}$ must be increased by 0.18 to 3.77 to fit into the $\mathrm{Al}_{2} \mathrm{O}_{3}$ and nmr data. This corresponds to an error of $5 \%$ in the $\mathrm{SiO}_{2}$ determination which is about the analytical error for Si determinations by AAS and the assumption of this error is therefore reasonable. The resulting formulae are shown in table 9. The content of $\mathrm{Ca}$ is 0.02 per $\mathrm{O}_{10}(\mathrm{OH})_{2}$.

It can be seen that if the numbers of tetrahedral cations are 4.00 (the ideal value) then the numbers of octahedral cations at $P_{I} 0.6$ are 2.18 and at $P_{1} 1.01 .95$.

The increase from $P_{I} 0.6$ to 1.0 and the ordering thus involves an increase in tetrahedral charge of 0.45 by $\mathrm{Al}$ for $\mathrm{Si}$ substitution and a decrease in octahedral charge of 0.20 by an increased amount of octahedral $\mathrm{Al}(0.18)$ and a decreased amount of $\mathrm{Fe}^{3+}(0.20)$ and of $\mathrm{Mg}^{2+}$ (0.19). This results in a decreased number of octahedral cations, from 2.18 to 1.95 . The content of $\mathrm{Fe}^{2+}$ is approximately the same at $\mathrm{P}_{\mathrm{I}} \mathbf{0 . 6}$ and 1.0. The net increase in charge, of $0.45-0.20$ $=0.25$, is accompanied by fixation of $0.19 \mathrm{NH}_{4}{ }^{+}$ and $0.12 \mathrm{~K}^{+}$, totalling 0.31 . This slightly higher figure can be due to analytical inaccuracy, since it is calculated from so many figures. Alternatively the slightly higher figure for fixed cations, 0.31 , than for net increase in charge, 0.25 , can be due to the decrease in octahedral charge of 0.20 and the corresponding increase in tetrahedral charge. This migration towards the interlayer of a charge of 0.20 gives stronger coulomb forces and can therefore result in increased fixation of $\mathrm{K}^{+}$and $\mathrm{NH}_{4}^{+}$.

Eberl (1986) carried out thermodynamic calculations for sodium/potassium exchange during smectite diagenesis occurring as a solid-state transformation. He concluded that a cation in a smectite interlayer dehydrates in response to increasing interlayer charge and that, for the same charge, the smallest ion is fixed preferentially. The cation with the smallest radius in the dehydrated state becomes the largest cation in the hydrated state. Accordingly, he concluded for the sodium-potassium exchange that potassium is greatly preferred compared to sodium when the layer charge required for potassium dehydration has been exceeded. In the present investigation, $\mathrm{NH}_{4}{ }^{+}$also became fixed. The ionic radii for dehydrated $\mathrm{NH}_{4}{ }^{+}, \mathrm{K}^{+}$and $\mathrm{Na}^{+}$are $1.43 \AA, 1.33 \AA$ and $0.98 \AA$, respectively (Sterne et al. 1982 and

Tab. 9. Elemental composition per $\mathrm{O}_{10}(\mathrm{OH})_{2}$ of illite/smectite, corresponding to 6 cations.

\begin{tabular}{lll}
\hline & $\mathrm{P}_{\mathbf{I}} 0.60$ & $\mathrm{P}_{\mathbf{I}} 1.00$ \\
\hline $\mathrm{Na}$ & 0.57 & 0.45 \\
$\mathrm{~K}$ & 0.30 & 0.42 \\
$\mathrm{NH}_{4}$ & $\frac{0.025}{0.90}$ & $\frac{0.22}{1.09}$ \\
& 0.32 & 0.13 \\
$\mathrm{Mg}$ & 1.49 & 1.67 \\
$\mathrm{Al}(6)$ & 0.054 & 0.037 \\
$\mathrm{Fe}^{2+}$ & $\underline{0.31}$ & 0.12 \\
$\mathrm{Fe}^{3+}$ & 2.18 & 1.95 \\
& 0.23 & 0.68 \\
$\mathrm{Al}(4)$ & $\frac{3.77}{4.00}$ & $\frac{3.32}{4.00}$ \\
$\mathrm{Si}$ & & \\
\hline
\end{tabular}


Eberl 1986). The smallest cation is, according to Eberl (1986), fixed preferentially. Therefore, the cations $\mathrm{NH}_{4}^{+}, \mathrm{K}^{+}$and $\mathrm{Na}^{+}$are fixed preferentially during increase of smectite interlayer charge as follows: At low smectite interlayer charge, all three cations are hydrated and $\mathrm{NH}_{4}{ }^{+}$aq. is adsorbed with slight preference over $\mathrm{K}^{+}{ }_{\text {aq. }}\left({ }_{\text {aq. }}\right.$. denotes a hydrated ion). When the interlayer charge increases, $\mathrm{NH}_{4}{ }^{+}$aq. is dehydrated first and then fixed with stronger preference over $\mathrm{K}^{+}{ }_{\text {aq }}$. and $\mathrm{Na}^{+}{ }_{\text {aq. }}$. When the interlayer charge is slightly increased further, $\mathrm{K}^{+}$aq. is also dehydrated and is then fixed slightly preferentially over $\mathrm{NH}_{4}{ }^{+}$(the radius of dehydrated $\mathrm{K}^{+}$is slightly smaller compared to $\mathrm{NH}_{4}^{+}$). When the interlayer charge is increased sufficiently to dehydrate $\mathrm{Na}^{+}{ }_{\text {aq. }}, \mathrm{Na}^{+}$is fixed with clear preference over $\mathrm{K}^{+}$and $\mathrm{NH}_{4}{ }^{+}$. The charge for $\mathrm{Na}^{+}$dehydration is apparently not achieved in the North Sea illite/smectites, whereas the increase in $\mathrm{NH}_{4}{ }^{+}$fixation at about $\mathrm{P}_{1}$ 0.7 (fig. 24) may be explained by dehydration of $\mathrm{NH}_{4}{ }^{+}$aq. at this $\mathrm{P}_{1}$ level. $\mathrm{NH}_{4}{ }^{+}$fixation is not increasing significantly with $P_{I}$ until this $P_{I}$ level, even if it should have a slight coulomb preference. But this is due to the fact that the cations are only adsorbed when hydrated and have to be dehydrated before fixation takes place. On the other hand, $\mathrm{NH}_{4}{ }^{+}$increases in pore waters at about the $P_{I}$ level 0.7 , and the increase in fixed $\mathrm{NH}_{4}{ }^{+}$may therefore be due to increase in the $\mathrm{NH}_{4}{ }^{+} / \mathrm{K}^{+}$ratio (see above).

The mechanism for formation of illite layers from smectite layers

The most distinct, depth-dependent clay mineralogical changes in the present investigation are the formation of illite layers from smectite layers and the ordering of these in mixed-layers. According to the literature review, illite layer formation can take place through a solid-state substitution or through a neoformation. The mechanism for the solid-state transformation is a tetrahedral substitution of $\mathrm{Al}^{3+}$ for $\mathrm{Si}^{4+}$ followed by $\mathrm{K}^{+}$fixation and layer contraction (Eberl \& Hower 1976; Eberl 1978a). Eberl \& Hower (1977) proposed that IS ordering can be explained by an electrical polarization effect during the solid-state transformation: tetrahedral substitution of $\mathrm{Al}$ for $\mathrm{Si}$ and the resulting increase in the negative charge takes place in one of the tetrahedral sheets of the 2:1 layer. Substitution in the other tetrahedral sheet in the same unit should then be less probable, and the resulting polarization effect should result in IS ordering. The activation energy for transforming two IS units to one SIII unit is then so much higher than that for IS unit formation that all smectite layers have to be present in IS units before SIII units are formed. According to this theory, ISI ordering is less likely to occur if polarization is strong enough to influence substitution in the tetrahedral sheet in the same 2:1 unit. If, however, the polarization power of illitic substituted layers is low then it may take two 2:1 illite layers to develop enough polarizing power to inhibit the formation of neighbouring illite layers (Eberl \& Hower 1977), and IIS units and ISI ordering may then be the result.

The alternative mechanism, proposed by $\mathrm{Na}$ deau et al. (1985), is a neoformation of illite layers. By this mechanism, smectite layers dissolve and illite layers crystallize from solution and grow in thickness. This mechanism is linked to the interparticle diffraction model of Nadeau et al. (1984) (see literature review) which considers the illite/smectite XRD patterns to be due to inter- and intra- particle diffraction in a specimen with such thin illite particles, perhaps also with some elementary smectite layers. Ordering is according to the interparticle diffraction model due to a mixture of thin illite particles with one, dominating particle thickness.

HRTEM investigations on intact bulk rock did not detect the thin illite particles of the neoformation theory of Nadeau et al. The thick particles with $10 \AA$ periods in contrast may, as discussed above, be MacEwan illite/particles and their smectite layers may be undergoing a solidstate transformation to illite layers, but they may also be illite particles. It was seen by HRTEM that each particle in intact bulk rock had its specific degree of ordering. This can be explained by the polarization effect operating in a solid-state transformation. The particles seen in HRTEM on intact rock are not aggregates, as dislocations are largely absent. The crystallization and growth of illite particles according to the neoformation theory cannot explain an occurrence of ordered $\mathrm{Ma}$ cEwan particles. Even if the particles with $20 \AA$ (or with $30 \AA$ ) period in contrast were interpreted 
as a stacking of thin illite particles, a crystallization and growth of thin illite particles can not be expected to form exactly equally thin illite particles within an aggregate. The observations by HRTEM on intact bulk rock therefore support the solid-state mechanism and are not compatible with the neoformation model of Nadeau et al. (1985).

XRD on specimens prepared from dispersed illite/smectite showed that randomly ordered or I-S segregated illite/smectite dominates the samples with $P_{I}$ less than 0.8 , and that IS ordered illite/smectite dominates the samples with $P_{1}$ in the interval $0.8-0.9$, whereas ISII ordering was found to dominate the single sample with $P_{I}$ of 0.95 . Although ISI ordered illite/smectite was detected by HRTEM on intact rock and was indicated by XRD by $\mathrm{CuK} \alpha$ radiation, it is not present in large amounts. This dominance of IS ordering in dispersed illite/smectite can be explained by the polarization effect in the solidstate transformation but could, according to the interparticle diffraction theory, also arise from a mixture of predominantly $20 \AA$ thick illite particles formed by neoformation. HRTEM on specimens prepared-from dispersed illite/smectite showed predominantly thin particles, which may be illite or elementary layers of smectite, and thus could be the result of a neoformation of illite. They may, however, equally well have formed from dispersion of MacEwan particles in intact bulk rock and this is probably the case, as thin particles were not observed in intact bulk rock by HRTEM. Specimens prepared for HRTEM from IS ordered illite/smectite also contained particles, which have $20 \AA$ periods in contrast and which, from the absence of Fresnel fringes in defocused images and from the absence of dislocations are true particles and not aggregates of thin particles. These true particles must then be IS ordered illite/smectite MacEwan particles according to the paragraph on Layer Structures in Intact Bulk Rock and in Dispersed Illite/ smectite. The occurrence of these particles is incompatible with the neoformation theory but fully compatible with a solid-state transformation.

The elemental composition per $\mathrm{O}_{10}(\mathrm{OH})_{2}$ of an end-member illite in the mixed-layer illite/smectite series (table 9) shows that this end member has 0.64 fixed cations, 0.29 octahedral Fe plus
$\mathrm{Mg}$, and 0.68 tetrahedral $\mathrm{Al}$. The total octahedral charge is -0.17 and the tetrahedral charge is -0.68 , summing to a charge of -0.85 . This is low compared to an ideal mica charge of -1.0 , and the number of fixed cations, 0.64 , is also low compared to a mica. Extrapolation of the plots of $\% \mathrm{MgO}$ vs. $\mathrm{P}_{\mathrm{I}}$ and of $\% \mathrm{Fe}_{2} \mathrm{O}_{3}$ vs. $\mathrm{P}_{\mathrm{I}}$ resulted in intercepts with the horizontal axis at $P_{I} 1.3$ in both plots (Lindgreen et al. 1991). This corresponds then to zero octahedral charge. Extrapolation to $P_{1} 1.3$ from the data in table 9 results in 0.88 fixed cations $\left(\mathrm{NH}_{4}^{+}\right.$plus $\mathrm{K}^{+}$) and $0.98 \mathrm{Al}(4)$, i.e. 0.98 tetrahedral charge. This is close to an ideal mica after the AIPEA classification (table 1). The finding of an ideal mica composition at $P_{I}$ 1.3 (Lindgreen et al. 1991) indicates that the illite layers contain about (1.3-1.0)/1.3 (i.e. $25 \%$ ) smectitic sites, which means sites of smectitic chemical composition. The end-member illite/ smectite must therefore contain smectitic sites, either in the illite layers or as terminal layers in each particle. If the smectitic sites are due to smectitic terminal layers in particles then the $25 \%$ smectitic sites correspond to particles about 4 layers thick, and this agrees well with the data in table 7 for samples with high $\mathrm{P}_{\mathrm{I}}$ values. Środon et al. (1986) calculated that the necessary charge for layer contraction was $\mathbf{- 0 . 5 5}$ for randomly ordered or I-S segregated illite/smectite and $\mathbf{- 1 . 0}$ for IS ordered illite/smectite. $20 \%$ of the layers in our illite/smectite have thus needed -1.0 and $15 \%$ of the layers a charge of -0.55 , giving a mean of -0.80 to increase $P_{1}$ from 0.65 to $P_{1} 1.00$ or overall a change of -0.32 from $P_{I} 0.60$ to 1.00 . This compares well with the $-0.45-(-0.20)=$ -0.25 as calculated from table 9 . Thus, the data in table 9 agree fairly well with the figures calculated by Srodon et al. (1986) for a solid-state transformation. Contraction at a layer charge of -0.55 means that smectitic sites must be present in the layers seen in XRD as illite. Eberl (1978a) calculated that illite formed from smectite by a solid state tetrahedral $\mathrm{Al}$ for $\mathrm{Si}$ substitution and $\mathrm{K}$ - fixation will have a layer charge of -0.77 . The charge of -0.85 of the illite layers in the present illite/smectites (see above) is compatible with the -0.77 of Eberl and with the contraction at layer charges of -0.55 (random ordering or I-S segregation) and -1.0 (IS ordering) after Środoń et al. (1986).

Formation of illite layers from smectite layers 
by a solid-state $\mathrm{Al}$ for Si transformation as proposed by Eberl \& Hower (1976) and Eberl (1978a) means that mixed layer illite/smectite will have tetrahedral sheets with different degrees of Al for Si substitution, i.e. the Markovian particle model of fig. 25. This agrees well with the tetrahedral substitutions calculated above for illite layers and the values of Srodon et al. (1986) required for layer contraction, which can give the values in the present illite/smectites. On the contrary, formation of illite layers from smectite layers by neoformation (from solution) as proposed by Nadeau et al. (1985) means that the illite layers all have the same, illitic degree of tetrahedral substitution (fig. 25), as inferred by $\mathrm{Al}$ taner et al. (1988). According to the neoformation model, separate smectite layers may be present together with the neoformed illite particles but only in very small amounts at high $P_{I}$ values, and the implications for $25 \%$ smectitic sites in the illite are incompatible with an occurrence of only illite particles. The composition of the 2:1 layer of the Jurassic illite/smectites of the present investigation therefore agrees well with what would result from a solid-state transformation but not with an ideal, illitic composition expected in thin illite particles.

Inoue, Watanabe, Kohyama \& Brusewitz (1990) tentatively concluded that, in the bentonites from Kinnekulle, Sweden, illitization was a solid-state transformation and proposed that this mechanism should take place in rocks with low porosity and permeability, such as bentonites and shales. According to Inoue et al. (1990), a low supply of the elements for illite layer formation should favour a transformation mechanism in low permeable rocks. In the present investigation, the increase in the amount of illite layers, from c. $60 \%$ to c. $85 \%$, requires only one half of the aluminum and potassium required for the increase in illite layers, from c. $25 \%$ to $80 \%$, in the US Gulf Coast illite/smectite (Perry \& Hower 1970 and Hower et al. 1976). Furthermore, the significant amount of ammonium available at the depth of ordering means that smaller amounts of potassium are necessary for illite layer formation. The more limited amounts of aluminum and potassium for illite layer formation in the North Sea than in the US Gulf Coast illite/smectite makes a solid-state illite layer transformation more likely in the North Sea, because only few (if any) smec- tite layers have to dissolve to provide aluminum (the model of Roberson \& Lahann 1981).

In summary, the illite/smectite structures seen by HRTEM in intact bulk rock and in dispersed illite/smectite are only compatible with the solidstate transformation but cannot have formed by a neoformation of thin illite particles. The charge of the contracted 2:1 layers is far from ideal mica and indicates that layer contraction at a charge of -0.77 has taken place and not a crystallization of mica layers with about -1.0 charge.

Thus the conclusion is that the formation of illite layers from smectite layers in the Upper Jurassic illite/smectites is a solid state transformation.

Acknowledgements. I am indebted to my collegues, lic. techn. Poul Lenvig Hansen, Laboratory of Applied Physics, Technical University of Copenhagen, and lektor, cand. scient. Hans Jørgen Jakobsen, Department of Chemistry, University of Aarhus, who with their cooperation and investigations by high resolution transmission electron microscopy and solid-state $\mathrm{nmr}$, respectively, contributed greatly to the understanding of the structure of the North Sea illite/smectite. I am also indebted to professor, dr. phil. Harry Micheelsen, Institute of Mineralogy, University of Copenhagen, for his constant encouragement, for the discussions during the investigation and for his comments on the present manuscripts.

I wish to thank cand. scient. Hans Jacobsen, Department of Chemistry, University of Aarhus, for his work on nmr spectroscopy; lektor, cand. real. Erik Leonardsen, and laborant Tove Poulsen, Institute of Mineralogy, University of Copenhagen, who ran the X-ray diffractograms; lektor, lic. techn. Daniel Højgaard Christensen, H. C. $\emptyset_{\text {rsted Institute, University of }}$ Copenhagen, who did infrared spectroscopy; and Mr. A. Birnie, The Macaulay Land Use Research Institute, Aberdeen, who made the shadowed specimens and provided the electron micrographs of these. Lektor Henrik Saaby Johansen, Department of Physics, Royal Veterinary and Agricultural University, kindly adviced me during the $\mathrm{NH}_{4}$-determinations by isotopic dilution. Dr. R. C. Reynolds, Dartmouth College, Hanover, New Hampshire and dr. P. D. Cradwick, Department of Scientific and Industrial Research, Private Bag, Lower Hut, New Zealand are thanked for letting me use their computer programs for X-ray diffraction mixed-layer simulations.

The University of Copenhagen is thanked for the post doctorate fellowship (seniorstipendium) which made this study possible, the Natural Science Research Council is thanked for financial support (J. nr. 11-5556), and statsgeolog H. Kristiansen for permission to complete this dissertation during my appointment at the Geological Survey of Denmark after September 1988. My thanks are due to lektor, dr. J. Bailey, who kindly corrected the English language and to Peter Moors and Benny Scharck, Graphical Section, Geological Survey of Denmark, who did the photographic work.

I furthermore wish to thank: cand. scient. T. Hoelstad; mag. scient. O. Jørgensen; lic. agro. Chr. Koch; cand. scient. H. Krabbe; professor, dr. phil. O. Michelsen; lektor, dr. techn. S. Mørup; dr. D. R. Pevear; professor, dr. agro. K. Rasmussen; dr. R. C. Reynolds; lektor, cand. scient. J. Rønsbo; cand. scient. P. Toft; professor, dr. A. Thölén; cand. scient. $O$. V. Vejbæk; and dr. M. J. Wilson, for valuable discussions, and I wish to thank laboratorietekniker S. Olsen, who adviced me 
during atomic absorption spectrophotometry at the Chemistry Department, Royal Veterinary and Agricultural University. The manuscript was finished in august 1990.

\section{Dansk sammendrag}

Der indledes med en kort gennemgang af lermineralernes opbygning med specielt henblik på veksellagsmineralernes struktur. Lermineralerne er opbyggede af tetraeder- og oktaederplader (eng.: sheets): i to-plademineralerne (kaolinit-serpentin gruppen) af en oktaederplade og en tetraederplade (1:1 lag), i tre-plademineraleme (pyrophyllit-talk, smektit, vermikulit, glimmer, sprødglimmer, og chlorit) af to tetraederplader og en oktaederplade (2:1 lag). I henhold til klassifikationen vedtaget af IMA (International Mineralogical Association) bestemmes grupperingen indenfor 2:1 phyllosilikaterne af ladningen pr. 2:1 enhed, dog adskiller chlorit sig ved at have en oktaederplade mellem 2:1 lagene. Opdelingen og klassifikationen af lermineralerne er af IMA vedtaget at følge klassifikationen for phyllosilikater, derfor er kvældningsegenskaber ikke medtaget i IMA klassifikationen. Flere af de mineraler, der tidligere er betegnet som illit, indeholder lagenheder af andre mineraler, oftest smektit, og er derfor veksellagsmineraler. Illit er derfor ikke anvendt som mineralnavn i IMA klassifikationen. Illit vil i nærværende arbejde blive brugt som betegnelse for et mineral i glimmergruppen, som har en fast $\mathrm{d}(001)$ på $10 \AA \AA$. Den af IMA vedtagne klassifikation af phyllosilikater (og lermineraler) er vist $i$ tabel 1 og opbygningen af et tre plademineral $i$ fig. 2 . Veksellagsmineraler indeholder lag af forskellige mineraler. To modeller for veksellagsmineralernes opbygning har været fremsat: 1) Markov modellen, ifølge hvilken veksellagsmineral partiklerne er relativt tykke og indeholder lag af alle de mineraler, der indgår i veksellagsmineralet (MacEwan partikler); og 2) fundamental-partikel modellen, ifølge hvilken veksellagsmineral partiklerne er tynde, ned til enkelte lag, og hver partikel kun indeholder lag af det ene af mineralerne i veksellagsmineralet. De to modeller er skitseret i fig. 2.

Der gives herefter et kort sammendrag af litteraturen om den diagenetiske omdannelse af smektitlag til illitlag i veksellagsmineralet af illit og smektit (illit/smektit).

Markov modellen var til at begynde med (i slutningen af 1960'erne og i 1970'erne) den almindeligt anerkendte model og blev grundlaget for de computer simuleringer af diagrammer fra røntgendiffraktion (XRD), som bl.a. Reynolds \& Hower (1970) viste. Sådanne computer simulerede diagrammer blev anvendt $\mathrm{i}$ undersøgelser af veksellagsmineralemes diagenetiske ændringer. Disse undersøgelser viste, at smektitlag $\mathrm{i}$ illit/smektit omdannes til illitlag ved temperaturer over $55^{\circ} \mathrm{C}$, samt at illit- og smektitlagene $\mathrm{i}$ illit/smektit var tilfaldigt ordnede op til et illitindhold på $60-70 \%$ og derover IS ordnede (d.v.s. ordnede i enheder på 1 illitlag +1 smektitlag), ISI (d.v.s. enheder på 1 smektitlag +2 illitlag) ordnede, eller ISII (d.v.s enheder på 1 smektitlag +3 illitlag) ordnede (Perry \& Hower 1970; Reynolds \& Hower 1970), se fig. 3. Ordningen af illit/smektit sker ved temperaturer på ca. $100^{\circ} \mathrm{C}$. Udover temperaturen synes ladning og kemisk sammensætning af smektitlagene samt mangden af kalium i porevæsken at vare bestemmende for processen. Undersøgelser fra områder med højere temperaturgradienter, ved metamorfose og hydrotermale betingelser, har også vist en omdannelse af smektitlag til illitlag med stigende temperatur. I hydrotermale eksperimenter er omdannelsen foregået ved $250^{\circ} \mathrm{C} \mathrm{og}$ derover. Unders $\emptyset$ gelse af bjergarter, der har undergået kortvarige, kraftige opvarmninger, har vist, at omdannelsen af smektitlag til illitlag er meget langsom sammenlignet med forøgelsen af vitrinits reflektionsevne.

Kalium indholdet stiger med indholdet af illit $\mathbf{i}$ illit/smektit (Perry \& Hower 1970; Hower et al. 1976). Endvidere fandt flere undersøgelser (Weaver \& Beck 1971; Hower et al. 1976; Foscolos et al. 1976) at dannelsen af illitlag ledsages af en forøgelse af mængden af aluminium $i$ illit/smektit og et fald af indholdet af jern, magnesium, og silicium, se fig. 6 . Hower et al. (1976) konkluderede, at dannelsen af illitlag fra smektitlag er en fast-fase transformation, en tetraedrisk substitution af aluminium for silicium og en påfølgende fiksering af kalium $i$ mellemlaget mellem 2:1 lagene. Denne hypotese blev støttet af hydrotermale eksperimenter (Eberl \& Hower 1976 og 1977). Dannelsen af illitlag i hydrotermale experimenter og $\mathrm{i}$ hdrotermale områder adskiller sig fra den diagenetiske omdannelse ved at der skabes højere negative ladninger i 2:1 lagene. Under hydrotermale betingelser kan natrium og calcium udover kalium dehydratiseres og fikseres, i modsætning til de diagenetiske omdannelser, hvor kun kalium dehydratiseres og fikseres.

Imidlertid udførte Nadeau, Wilson, McHardy \& Tait kombinerede unders $\emptyset$ gelser med XRD og transmissions elektron mikroskopi (TEM) af skyggede praparater af disaggregeret illit/ smektit fra sandsten og bentoniter (Nadeau et al. 1984, 1985). De opstillede herudfra fundamental partikel teorien, se ovenfor. Endvidere argumenterede de for, ud fra partikeltykkelses fordelinger af illit/smektit med forskelligt indhold af illitlag, at med stigende grad af diagenese opløses smektitlagene, og illitlagene dannes ud fra de opløste ioner og vokser $i$ størrelse (Nadeau et al. 1985). Undersøgelser med højopløsende transmissions elektronmikroskopi (HRTEM) udført af Ahn \& Peacor (1986a) på intakte bjergarter fra de prøver, Perry \& Hower (1970) og Hower et al. (1976) havde undersøgt med XRD, kunne ikke påvise tynde, fundamentale partikler $i$ de intakte bjergarter, men kun tykke "pakker". Disse pakker var enten regelmæssige og blev af Ahn og Peacor ud fra morfologi og EDAX analyse vurderet til at være illit, eller de var bølgende og blev af Ahn og Peacor vurderet til at være smektit. Ahn og Peacor mente ud fra forløbet af lagenes kontraststriber i HRTEM, at smektitpartiklerne opløstes og illitpartiklerne voksede langs partikelkontakter mellem illit og smektitpartiklerne. Ahn og Peacor har dog senere (Ahn \& Peacor 1989) reevalueret deres resultater og anerkendt eksistensen af illit/ smektit partikler i deres materiale. Mængden af tilgængeligt kalium er den begrænsende faktor i dannelsen af illitlag fra smektitlag. Dog kan andre kationer, såsom af magnesium, calcium, og natrium, i systemer med tilstrækkeligt tilgængeligt kalium forhindre kaliumfikseringen og dermed dannelsen af illitlag.

Frigivelsen af vand fra omdannelsen af smektit til illit og betydningen af dette vand for migrationen af kulbrinter fra kildebjergarter har været genstand for flere undersøgelser. Der synes at vare et sammenfald mellem omdannelsen af smektitlag til illitlag og dannelsen af olie og gas. Men betydningen af det frigjorte vand for olie-gas migrationen er ikke afklaret.

Geologien af Det danske Centraltrug og af Det norsk danske Bassin gennemgås kort. Tykke lerlag blev i Øvre Jura aflejret i Det norsk-danske Bassin og især i Centraltruget, hvor de er rige på organisk stof (algemateriale). Indsynkning i Kridt og især $i$ Tertiær resulterede $\mathrm{i}$ oliedannelse $\mathrm{i}$ lerlagene $\mathrm{i}$ Centraltruget. De Øvre Jurassiske lersten har nok overvejende Det fennoskandiske Skjold som kildeområde. Derudover er der sandsynligvis sket en sedimentation af vulkansk materiale indbefattende aske i Nordsøregionen i Øvre Jura.

Lerbjergarter fra Mandal, Farsund, og Haugesund formationerne i Centraltruget og fra Sauda, Tau, Børglum og Bream formationerne i Det norsk-danske Bassin er blevet undersøgt. Det undersøgte materiale er fra dansk landområde kerner, suppleret med cuttingsmateriale, og fra Nordsøen cuttingsmateriale, suppleret med to kerner fra boringerne 2/11-1 og E1. Fra cuttings er fra hver prøve udsorteret den grå-mørkegrå $\emptyset$ vre Jurassiske lersten.

På prøver af intakte bjergarter (tyndslib, indstøbt i epoxy og ionatset) er anvendt højopløsende transmissions elektronmikroskopi (HRTEM). På forbehandlede og fraktionerede prøver 
er anvendt røntgendiffraktion (XRD), og på isoleret illit/smektit er anvendt XRD, HRTEM, transmissions elektronmikroskopi af skyggede praparater (TEM), faststof ${ }^{27} \mathrm{Al} \mathrm{og}{ }^{29} \mathrm{Si}$ kernemagnetisk resonans spektroskopi (MAS-NMR), Mössbauer spektroskopi, og infrarød spektroskopi, samt bestemmelse af $\mathrm{K}, \mathrm{Na}, \mathrm{Mg}, \mathrm{Ca}, \mathrm{Al}, \mathrm{Fe}, \mathrm{Si}, \mathrm{og} \mathrm{NH}_{4}{ }^{+}$. K, $\mathrm{Na}, \mathrm{Mg}, \mathrm{Ca}, \mathrm{Al}, \mathrm{Fe}$, og Si bestemtes ved atomabsorptions spektrofotometri efter $\mathrm{HF}$ oplukning i teflonbomber og efterfølgende kompleksdannelse med $\mathrm{H}_{3} \mathrm{BO}_{3} . \mathrm{NH}_{4}{ }^{+}$bestemtes $\mathrm{i}$ illit/smektit, efter opvarmning af ca. $1 \mathrm{mg}$ prøve ved $600^{\circ}$ og oxidation af nitrogen til $\mathrm{N}_{2}$, ved emissionsspektroskopi og beregning ud fra en isotopfortyndingsmetode. Tolkningen af resultaterne fra XRD og HRTEM blev støttet af computer modelleringer, for XRD med NEWMOD programmet udviklet af R.C.Reynolds for tokomponent veksellagsmineraler og med et program udviklet af P.D.Cradwick for trekomponent veksellagsmineraler. Med XRD blev illitindholdet $i$ og ordningen af illit/smektit vurderet ud fra sammenligninger mellem simulerede og kørte diffraktogrammer. Eksempler på simulerede og kørte diffraktogrammer er vist $i$ fig. $11 \mathrm{a}$ og b. I visse illit/smektit prøver synes der udover illit og smektit at være en tredje komponent, vermikulit.

Lermineralogien $\mathrm{i}$ grovlersfraktionerne $(2-0.2 \mu \mathrm{m})$ støtter ideen om, at leret i Centraltruget og Det norsk danske Bassin i overvejende grad stammer fra forvitring og jordbundsdannelse på Det fennoskandiske Skjold, og at der under denne forvitring er dannet tilfældigt ordnet eller illit-smektit segregeret illit smektit med ca. $70 \%$ illitlag. (Illit-smektit segregering vil sige, at illitlag har en tendens til at følge illitlag og smektitlag en tendens til at følge smektitlag.) Dog er der $i$ to boringer $i$ Centraltruget, W1 og $2 / 7-3$, fundet lerlag af sandsynlig vulkansk oprindelse. Den detritale, tilfaldigt ordnede eller illitsmektit segregerede illit/smektit med ca. $70 \%$ illitlag er under diagenesen i Centraltruget omdannet til IS ordnet illit/smektit med $80-90 \%$ illitlag og til ISII ordnet illit/smektit med ca. $95 \%$ illitlag. Den formodet bentonitiske illit/smektit er blevet omdannet til tilfældigt ordnet eller illit-smektit segregeret illit/ smektit med $40-50 \%$ illitlag. I Det norsk-danske Bassin er temperaturerne under indsynkningen ikke nået så højt op, at den detritale, tilfældigt ordnede eller illit-smektit segregerede illit/smektit er blevet ændret. I $\mathrm{K}^{+}$-mættede og glycolerede prøver er ca. halvdelen af smektitlagene (bestemt ud fra $\mathrm{Mg}^{2+}$. mattede og glycolerede eller lufttørre prøver) kontraherede til ca. $10 \AA$, se fig. 23. Dette forhold galder for alle prøver og kan forklares med, at ca. halvdelen af smektitlagene har en høj ladning som gør, at de $\mathrm{i} \mathrm{K}{ }^{+}$- mættet tilstand forbliver sammenklappede. XRD af praparater med partiklerne i tilfaldig orientering viser, at $\mathrm{d}(060)$ er tilnærmelsesvis konstant (1.495$1.501 \AA$ ) for varierende illitindhold $i$ illit/smektit, mens halvliniebredden falder med stigende indhold af illit; altså har de dannede illitlag tilnærmelsesvis samme d(060) som smektitlagene. At d(060) ikke andres under den tetraedriske ombytning af Si med Al (se nedenfor) kan forklares ud fra en øget grad af rotation af tetraedrene $i$ illitlagene.

Undersøgelsen af intakte bjergartsprøver med HRTEM viser, at partikler med $10 \AA, 20 \AA, \operatorname{og} 30 \AA$ periode i billedkontrast findes $i$ alle prøver, $i$ enkelte prøver tillige partikler med forskellige perioder (op til $40 \AA$ ) i samme partikel, se fig. 15. Computer simuleringer viser, at ordnede lag af illit plus Na-smektit (IS ordning) kan give $20 \AA$ perioder. $2 \mathrm{M}$ glimmer kunne også give $20 \AA$ perioder under specielle instrumentbetingelser, men kan ikke detekteres med XRD i prøverne. Det konkluderes derfor at der $i$ de intakte bjergarter findes veksellags illit/smektit partikler (MacEwan partikler). HRTEM på dispergeret illit/smektit fra de samme prøver viser, at partiklerne $\mathrm{i}$ dispergerede prøver gennemgående er tyndere end $\mathrm{i}$ de intakte bjergarter. Dette indicerer, at partiklerne ved dispergeringen er gået i stykker. Partikeltykkelses fordelinger beregnet ud fra TEM på skyggede præparater af dispergeret illit/ smektit (se fig. 17) viser, at tilfældigt ordnet og illit-smektit segregeret illit/smektit består overvejende af $10 \AA$ og $20 \AA$ tykke partikler, mens ordnet illit/smektit med større mængde illitlag er kendetegnet ved en bredere fordeling af $10 \AA-60 \AA$ tykke partikler. Dog findes der i henhold til HRTEM stadig partikler med $20 \AA$ perioder, MacEwan partikler, $\mathrm{i}$ de dispergerede illit/smektit prøver, som derfor ikke, som antaget af Nadeau et al. (1984, 1985), består alene af "fundamentale" illitpartikler og enkeltlags smektitpartikler, se fig. 16.

$\mathrm{Si} / \mathrm{Al}$ forholdet $\mathrm{i}$ illit/smektit fraktionerne bestemt med ${ }^{27} \mathrm{Al}$ og ${ }^{29} \mathrm{Si}$ MAS-NMR på den ene side og med totalkemisk analyse på den anden side viser god overensstemmelse. Derimod er bestemmelserne af tetraedrisk og oktaedrisk $\mathrm{Al}$ ved ${ }^{27} \mathrm{Al} \mathrm{og}{ }^{29} \mathrm{Si}$ MAS-NMR betydeligt nøjagtigere end beregningen ud fra totalkemisk analyse. Mens der $\mathrm{i}$ det ene af de foreliggende arbejder (Lindgreen et al: 1991) ikke med Mössbauer spektroskopi kunne konstateres en sammenhæng mellem $\mathrm{Fe}^{3+} / \mathrm{Fe}^{2+}$ forholdet $\mathbf{i}$ illit/smektit og mængden af illitlag, synes dette forhold, efter analyse af et større antal prøver, at falde ved omdannelsen af smektitlag til illitlag. Den betydelige linieforbredning af $\mathrm{Fe}^{3+}$ linierne for illit/smektit $i$ Mössbauer spektrene gør det ikke muligt at drage mere detaljerede slutninger om de diagenetiske omdannelser i oktaederpladen. Derimod giver ${ }^{27} \mathrm{Al} \mathrm{og}{ }^{29} \mathrm{Si}$ MAS-NMR nøjagtige data for fordelingen af Si og Al i oktaeder- og tetraederpladerne. Under omdannelsen af den detritale, tilfældigt ordnede eller illit-smektit segregerede illit/smektit med $70 \%$ illitlag til ordnet illit/smektit med $80-95 \%$ illitlag er hovedprocessen en ombytning af Si med $\mathrm{Al}$ i tetraederpladerne og en dehydratisering og fiksering i mellemlaget af $\mathrm{K}^{+}$og $\mathrm{NH}_{4}{ }^{+}$. Det skal her bemærkes, at $\mathrm{NH}_{4}{ }^{+}$ikke tidligere er blevet bestemt $\mathrm{i}$ kemiske undersøgelser af veksellagsmineraler. Forholdet $\mathrm{NH}_{4}{ }^{+} / \mathrm{K}^{+} \mathrm{i}$ illit/smektit begynder at stige ved den dybde, hvor dannelsen af illitlag $\mathrm{i}$ illit/smektit begynder. I samme dybde stiger forholdet mellem de to ioner adsorberet på leret og i porevæsken, se fig. 21 . Udover hovedprocessen sker en mindre ombytning af $\mathrm{Fe}$ og $\mathrm{Mg}$ i oktaederpladen med $\mathrm{Al}$. For en stigning $i$ illitindholdet $\mathrm{i}$ illit/smektit fra $60 \%$ til $100 \%$ kan ombytningerne pr. $\mathrm{O}_{10}(\mathrm{OH})_{2}$ beregnes at medføre en stigning i tetraederpladens negative ladning på 0.45 , et fald $\mathrm{i}$ oktaederpladens negative ladning på 0.20 , og en stigning $i$ mængden af fikseret $\mathrm{K}^{+}$på $0.12 \mathrm{og}$ af fikseret $\mathrm{NH}_{4}{ }^{+}$på 0.19 . En illit/smektit med $100 \%$ illitlag indeholder dog stadig væsentlige mængder $\mathrm{Fe}$ og $\mathrm{Mg}$ i oktaederpladen og ladningen er $-0.85 \mathrm{pr}$. $\mathrm{O}_{10}(\mathrm{OH})_{2}$. Ekstrapoleres plottene for kemisk sammensatning versus mængden af illitlag $\mathrm{i}$ illit/smektit, fâs, ved et illitindhold på $130 \%$, et mineral med kun $\mathrm{Al} i$ oktaederpladen og med en negativ ladning på 0.98 stammende alene fra ombytning af $\mathrm{Si}$ med Al i tetraederpladen, altså en glimmer $\mathrm{i}$ henhold til IMA klassifikationen (tabel 1). Dette tyder på, at illitlagene indeholder ca. $25 \%$ smektit positioner, d.v.s. positioner med smektits kemiske sammensætning. Dette, og den regelmassige ordning i $20 \AA$ (og i ringe grad $30 \AA$ ) periode i kontrast (svarende til henholdsvis en IS ordning $(20 \AA)$ og en ISI ordning $(30 \AA)$ ) i illit/smektit partiklerne $i$ den intakte bjergart, samt den konstante b-dimension bestemt ud fra (060) i XRD, tyder på, at dannelsen af illitlag ud fra smektitlag $i$ illit/smektit i de undersøgte prøver er en fastfaseomdannelse, en transformation.

\section{References}

Ahn, J. H. \& Buseck, P. R. 1990: Layer-stacking sequences and structural disorder in mixed-layer illite/smectite: Image simulations and HRTEM imaging. Amer. Mineral., 75, 267-275.

Ahn, J. H. \& Peacor, D. R. 1985: Transmission electron microscopic study of diagenetic 
chlorite in Gulf Coast argillaceous sediments. Clays \& Clay Miner., 33, 228-236.

Ahn, J. H. \& Peacor, D. R. 1986a: Transmission and analytical electron microscopy of the smectite to-illite transition. Clays \& Clay Miner., 34, 165-179.

Ahn, J. H. \& Peacor, D. R. 1986b: Transmission electron microscope data for Rectorite: implications for the origin and structure of "fundamental particles". Clays \& Clay Miner., 34, 180186.

Ahn, J. H. \& Peacor, D. R. 1987: Transmission electron microscopic study of the diagenesis of kaolinite in Gulf Coast argillaceous sediments. In: Proc. Int. Clay Conf., Denver, 1985, L. G. Schultz, H. van Olphen, \& F. A. Mumpton, eds., Clay Miner. Soc., Bloomington, Indiana, 151157.

Ahn, J. H. \& Peacor, D. R. 1989: Illite/smectite from Gulf Coast shales: A reappraisal of transmission electron microscope images. Clays \& Clay Miner., 37, 542-546.

Altaner, S. P., Weiss, C. A. Jr., \& Kirkpatrick, R. J. 1988: Evidence from ${ }^{29} \mathrm{Si}$ N.M.R. for the structure of mixed-layer illite/smectite clay minerals. Nature, 331, 699-702.

Altaner, S. P. \& Bethke, C. M. 1988: Interlayer order in illite/smectite. Amer. Mineral., 73, 766-774.

Anderson, J. U. 1963: An improved pretreatment for mineralogical analysis of samples containing organic matter. In: Clays and Clay Miner., Proc. 10th Natl. Conf., Austin, Texas, 1961, A. Swineford \& P. C. Franks, eds., Pergamon Press, New York, 380-388.

Anjos, S. M. C. 1986: Absence of clay diagenesis in Cretaceous-Tertiary marine shales, Campos Basin, Brazil. Clays \& Clay Miner., 34, 424-434.

Aoyagi, K. \& Asakawa, T. 1984: Paleotemperature analysis by authigenic minerals and its application to petroleum exploration. Amer. Assoc. Pet. Geol. Bull., 68, 903-913.

Aoyagi, K. \& Kazama, T. 1980: Transformational changes of clay minerals, zeolites and silica minerals during diagenesis. Sedimentology, 27, 179-188.

Bailey, S. W. 1980: Summary of recommendations of AIPEA Nomenclature. Clays \& Clay Miner. , 28, 73-78.

Bailey, S. W. 1984: Structures of layer sili- cates. In: Crystal Structures of Clay Minerals and their X-ray Identification. G. W. Brindley \& G. Brown, eds., Mineral. Soc., London, 1-124.

Bethke, C. M. \& Altaner, S. P. 1986: Layerby-layer mechanism of smectite illitization and application to a new rate law. Clays \& Clay Miner., 34, 136-145.

Birkelund, T., Clausen, C. K., Hansen, H. N., \& Holm, L. 1983: The Heteroceras kochi zone (Ryazanian) in the North Sea Central Graben and remarks on the Late Cimmerian Unconformity. Geol. Surv. Denmark. Yearbook 1982, 53-72.

Bjørlykke, K., Dypvik, H., \& Finstad, K. G. 1975: The Kimmeridgian shale, its composition and radioactivity. In: Jurassic Northern North Sea Symposium, K. G. Finstad \& R. C. Selley, eds., Norwegian Petroleum Soc., Stavanger, JNSS/12, 20pp.

Bogomolov, G. V., Kudel'skiy, A. V., \& Kozlov, M. F. 1970: The ammonium ion as an indicator of oil and gas: Doklady Akademii Nauk SSSR, 195, 938-940.

Boles, J. R. \& Franks, S. G. 1979: Clay diagenesis in Wilcox sandstones of southwest Texas: implications of smectite diagenesis on sandstone cementation. J. Sed. Petrol., 49, 55-70.

Brindley, G. W. 1966: Report on the work of the Nomenclature and Liaison Committee of the Clay Minerals Society, 1963-64. Clays and Clay Minerals, Proc. 13th Natl. Conf., Madison, Wisconsin, 1964, W. F. Bradley \& S. W. Bailey, eds., Pergamon Press, New York, 429-432.

Brindley, G. W. 1981: X-ray identification (with ancillary techniques) of clay minerals. $I n$ : Clays and the Resource Geologist, F. J. Longstaffe, ed., Mineral. Assoc. Canada, Short Course Notes, 7, 22-38.

Brockamp, O. 1979: Diagenetische Veränderungen von Montmorilloniten in Alb-Sedimenten Norddeutschlands. Fortschr. Geol. Rheinld. $u$. Westf., 27, 121-136.

Brown, G. \& Brindley, G. W. 1984: X-ray diffraction procedures for clay mineral identification. In: Crystal Structures of Clay Minerals and their X-ray Identification: G. W. Brindley and G. Brown, eds., Mineral. Soc., London, 305-360.

Bruce, C. M. 1984: Smectite dehydration- Its relation to structural development and hydrocarbon accumulation in Northern Gulf of Mexico Basin. Amer. Assoc. Pet. Geol. Bull., 68, 673683. 
Burst, J. F. 1959: Postdiagnetic clay mineral environmental relationships in the Gulf Coast Eocene. In: Clays and Clay Miner., Proc. 6th Natl. Conf., Berkeley, California, 1959, A. Swineford, ed., Pergamon Press, New York. 327341.

Burst, J. F. 1969: Diagenesis of Gulf Coast clayey sediments and its possible relation to petroleum migration. Amer. Assoc. Pet. Geol. Bull., 53, 73-93.

Burtner, R. L. \& Warner, M. A. 1986: Relationship between illite/smectite diagenesis and hydrocarbon generation in Lower Cretaceous Mowry and Skull Creek shales of the Northern Rocky Mountain area. Clays \& Clay Miner., 34, 390-402.

Cayley, G. T. 1987: Hydrocarbon migration in the Central North Sea. In: Petroleum Geology of North West Europe, 1, J. Brooks \& K. W. Glennie, eds., Graham and Trotman, London, 549556.

Chang, H. K., Mackenzie, F. T., \& Schoonmaker, J. 1986: Comparisons between the diagenesis of dioctahedral and trioctahedral smectite, Brazilian offshore basins. Clays \& Clay Miner., 34, 407-423.

Chourabi, B. \& Fripiat, J. J. 1981: Determination of tetrahedral substitutions and interlayer surface heterogeneity from vibrational spectra of ammonium in smectites. Clays \& Clay Miner., 29, 260-268.

Christensen, O. B. 1974: Marine communications through the Danish Embayment during Uppermost Jurassic and Lowermost Cretaceous. Geoscience and Man, 6, 99-115.

Cowperthwaite, I. A., Fitch, F. J., Miller, J. A., Mitchell, J. G. \& Robertson, R. M. S. 1972: Sedimentation, petrogenesis and radioisotopic age of the Cretaceous Fuller's Earth of Southern England. Clay Miner., 9, 309-327.

Cox, B. M. \& Gallois, R. W. 1981: The stratigraphy of the Kimmeridge Clay of the Dorset type area and its correlations with some other Kimmeridgian sequences. Rep. Inst. Geol. Sci., No. 80/4, 44pp.

Cradwick, P. D. \& Wilson, M. J. 1978: Calculated X-ray diffraction curves for the interpretation of a three-component interstratified system. Clay Miner., 13, 53-65.

Davidtz, J. C. \& Low, P. F. 1970: Relation between crystal lattice configuration and swelling of montmorillonites. Clays \& Clay Miner., 18, 325-33

Deconinck, J.-F., Chamley, H., Debrabant, P., \& Colebeaux, J. P. 1983: Le Boulonnais au Jurassique supérieur: données de la minéralogie des argiles et de la géochemie. Ann. Soc. Géol. Nord, 102, 145152.

Delfaud, J. 1983: Les paleoclimats du Jurassique en Europe Occidentale. Bull. Inst. Géol. Bassin d'Aquitaine, 34, 121-135.

Dixon, J. E., Fitton, J. G. \& Frost, R. T. C. 1981: The tectonic significance of Post-Carboniferous igneous activity in the North Sea Basin. In: Petroleum Geology of the Continental Shelf of North West Europe, L. V. Illing \& G. D. Hobson, eds., Inst. Petroleum, London, 121-137.

Dunoyer de Segonzac, G. 1970: The transformation of clay minerals during diagenesis and low-grade metamorphism: a review. Sedimentology, 15, 281-346.

Dypvik, H. 1983: Clay mineral transformations in Tertiary and Mesozoic sediments from North Sea. Amer. Assoc. Pet. Geol. Bull., 67, 160-165.

Eberl, D. 1978a: The reaction of montmorillonite to mixed layer clay: the effect of interlayer alkali and alkaline earth cations. Geochim. Cosmochim. Acta, 42, 1-7.

Eberl, D. 1978b: Reaction series for dioctahedral smectites: Clays \& Clay Miner., 26, 327340.

Eberl, D. D. 1980: Alkali cation selectivity and fixation by clay minerals. Clays \& Clay Miner., 28, 161-172.

Eberl, D. D. 1984: Clay mineral transformations in rocks and soils. Phil. Trans. R. Soc. Lond., A311, 241-257.

Eberl, D. 1986: Sodium-potassium ion exchange during smectite diagenesis - A theoretical discussion. In: Studies in Diagenesis, F. A. Mumpton, ed., U.S. Geol. Surv. Bull., 1578, 363-368.

Eberl, D. \& Hower, J. 1976: Kinetics of illite formation. Bull. Geol. Soc. Amer., 87, 13261330.

Eberl, D. \& Hower. J. 1977: The hydrothermal transformation of sodium and potassium smectite into mixed-layer clay. Clays \& Clay Miner., 25, 215-227.

Eslinger, E., Highsmith, P., Albers, D., \& DeMayo, B. 1979: Role of iron reduction in the conversion of smectite to illite in bentonites in 
The Disturbed Belt, Montana. Clays \& Clay Miner., 27, 327-338.

Eslinger, E. \& Savin, S. 1973: Oxygen isotope geothermometry of the burial metamorphic rocks of the Precambrian Belt Supergroup, Glacier National Park, Montana. Geol. Soc. Amer. Bull., 84, 2549-2560.

Eslinger, E. \& Sellars, B. 1981: Evidence for the formation of illite from smectite during burial metamorphism in the Belt Supergroup, Clark Fork, Idaho. J. Sed. Petrol., 51, 203-216.

Espitalie, J., Madec, M., Tissot, B., Menig, J. J., \& LePlat, P. 1977: Source rock characterization method for petroleum exploration. In: Proc. 9th Annual Offshore Techn. Conf., Houston, Texas, 1977, 3, 439-448.

Evans, T. R. \& Coleman, N. C. 1974: North Sea geothermal gradients. Nature, 247, 228-230.

Farmer, V. C. 1974: The Infrared Spectra of Minerals. Mineral. Soc., London.

Farmer, V. C. \& Russell, J. D. 1964: The infrared spectra of layer silicates. Spectrochim. Acta, 20, 1149-1173.

Follett, E. A. C., McHardy, W. J., Mitchell, B. D., \& Smith, B. F. L. 1965: Chemical dissolution techniques in the study of soil clays: Part II. Clay Minerals, 6, 35-43.

Foscolos, A. E. \& Powell, T. G. 1979: Mineralogical and geochemical transformation of clays during burial diagenesis (catagenesis): relation to oil generation. In: Proc. Int. Clay Conf., Oxford, M. M. Mortland \& V. C. Farmer, eds., Dev. Sedimentology, 27, 261-270.

Foscolos, A. E., Powell, T. G., \& Gunther, P. R. 1976: The use of clay minerals and inorganic and organic geochemical indicators for evaluating the degree of diagenesis and oil generating potential of shales. Geochim. Cosmochim. Acta, 40, 953-966.

Foscolos, A. E. \& Stott, D. F. 1975: Degree of diagenesis, stratigraphic correlations and potential sediment sources of Lower Cretaceous shale of northeastern British Columbia. Bull. Geol. Surv. Can., 250, 46pp.

Francis, J. E. 1984: The seasonal environment of the Purbeck (Upper Jurassic) fossil forests. Palaeogeogr., Palaeoclimatol., Palaeoecol., 48, 285-307.

Frank-Kamenetski, V. A., Kotelnikova, E. N., Kotov, N. V., \& Starke, R. 1979: Influence of tetrahedral aluminium on the hydrothermal transformation of montmorillonite and beidellite to mixed-layer illite-montmorillonite and illite. Kristall und Technik, 14, 303-311.

Freed, R. L. \& Peacor, D. R. 1989: Variable temperature of the smectite/illite reaction in Gulf Coast sediments. Clay Miner., 24, 171-180.

Frey, M. 1970: The step from diagenesis to metamorphism in pelitic rocks during Alpine orogenesis. Sedimentology, 15, 261-279.

Gallois, R. W. 1976: Coccolith blooms in the Kimmeridge Clay and origin of North Sea oil. Nature, 259, 473-475.

Gibbs, R. J. 1965: Error due to segregation in quantitative clay mineral X-ray diffraction mounting techniques. Amer. Mineral., 50, 741751.

Gibbs, R. J. 1977: Clay mineral segregation in the marine environment. J. Sed. Petrol., 47, 237243.

Goodman, B. A. 1976: The Mössbauer spectrum of a ferrian muscovite and its implications in the assignment of sites in dioctahedral micas. Mineral. Mag., 40, 513-517.

Gowers, M. B. \& Sxbøe, A. 1985: On the structural evolution of the Central Trough in the Norwegian and Danish sectors of the North Sea. Marine Pet. Geol., 2, 298-318.

Grim, R. E. 1953: Clay Mineralogy. McGrawHill, London, 383pp.

Grim, R. C. 1958: Concept of diagenesis in argillaceous sediments. Amer. Assoc. Pet. Geol. Bull., 42, 246-253.

Grim, R. E. \& Güven, N. 1978: Bentonites. Geology, Mineralogy, Properties and Uses. Dev. Sedimentology, 24, Elsevier, Amsterdam, 256 pp.

Guthrie, G. D. \& Veblen, D. R. 1989: Highresolution transmission electron microscopy of mixed-layer illite/smectite: Computer simulations. Clays \& Clay Miner., 37, 1-11.

Guthrie, G. D. \& Veblen, D. R. 1990: Interpreting one dimensional high-resolution transmission electron micrographs of sheet silicates by computer simulations. Amer. Mineral., 75, 276288.

Hallam, A. \& Sellwood, B. W. 1968: Origin of Fuller's Earth in the Mesozoic of Southern England. Nature, 220, 1193-1195.

Hancock, N. J. \& Taylor, A. M. 1978: Clay mineral diagenesis and oil migration in the Mid- 
dle Jurassic Brent Sand Formation. J. Geol. Soc. London, 135, 69-72.

Hansen, P. L. \& Lindgreen, H. 1989: Mixedlayer illite/smectite diagenesis in Upper Jurassic claystones from the North Sea and onshore Denmark. Clay Miner., 24, 197-213.

Hanshaw, B. B. 1964: Cation-exchange constants for clays from electronical measurements. In: Clays and Clay Miner., Proc. Natl. Conf., Atlanta, Georgia, 1963, W. F. Bradley, ed., Pergamon Press, New York, 397-421.

Hay, R. L., Lee, M., Kolata, D. R., Matthews, J. C., \& Morton, J. P. 1988: Episodic potassic diagenesis of Ordovician tuffs in the Mississippi Valley area. Geology, 16, 743-747.

Heling, D. 1978: Diagenesis in argillaceous sediments of the Rhinegraben. Clay Miner., 13, 211-220.

Heling, D. 1979: Die Diagenese der Tonsteine und Silttonsteine im mittleren Oberrein-Graben. Fortschr. Geol. Rheinld. u. Westf., 27, 75-85.

Heling, D. \& Teichmüller, K. 1974: Die Grenze Montmorillonit/Mixed Layer-Minerale und ihre Beziehung zur Inkohlung in der grauen Schichtenfolge des Oligozäns im Oberrheingraben. Fortschr. Geol. Rheinld. u. Westf., 24, 113128.

Hillier, S. \& Clayton, T. 1989: Illite/smectite diagenesis in Devonian lacustrine mudrocks from Northern Scotland and its relationship to organic maturity indicators. Clay Miner., 24, 181-196.

Higashi, S. 1978: Dioctahedral mica minerals with ammonium ions. Mineral. J., 9, 16-27.

Hoelstad, T. 1986: Palynology and palynofacies of the Middle Jurassic to Lower Cretaceous in the Danish Central Trough. Geol. Surv. Denmark, Internal Rep. no. 43, 40 p.

Hoffman, J., \& Hower, J. 1979: Clay mineral assemblages as low grade metamorphic geothermometers: application to the thrust faulted Disturbed Belt of Montana, U.S.A.. Soc. Econ. Paleont. Mineral. Sp. Pap., 26, 55-79.

Horton, D. G. 1985: Mixed-layer illite/smectite as a paleotemperature indicator in the Ametyst vein system, Creede district, Colorado, USA. Contrib. Mineral. Petrol., 91, 171-179.

Howard, J. J. 1981: Lithium and potassium saturation of illite/smectite clays from interlaminated shales and sandstones. Clays \& Clay Miner., 29, 136-142.

Howard, J. J. \& Roy, D. M. 1985: Devel- opment of layer charge and kinetics of experimental smectite alteration. Clays \& Clay Miner., 33, 81-88.

Hower, J. 1967: Order of mixed-layering in illite/montmorillonites. In: Clays and Clay Miner., Proc. 15th Natl. Conf., Pittsburgh, Pennsylvania, 1966, S. W. Bailey, ed., Pergamon Press, New York, 63-74.

Hower, J. 1981a: X-ray diffraction identification of mixed layer clay minerals. In: Clays and the Resource Geologist, F. J. Longstaffe, ed., Mineral. Assoc. Canada, Short Course Handbook, 7, 39-59.

Hower, J. 1981b: Shale diagenesis. In: Clays and the Resource Geologist, F. J. Longstaffe, ed., Mineral. Assoc. Canada, Short Course Handbook, 7, 60-80.

Hower, J., Eslinger, E. V., Hower, M. E., \& Perry, E. A. 1976: Mechanism of burial metamorphism of argillaceous sediment: 1. Mineralogical and chemical evidence. Bull. Geol. Soc. Amer, 87, 725-737.

Hower, J. \& Mowatt, T. C. 1966: The mineralogy of illites and mixed-layer illite/montmorillonites. Amer. Mineral., 51, 825-854.

Howitt, F., Aston, E. R. \& Jaqué, M. 1975: The occurrence of Jurassic volcanics in the North Sea. In: Petroleum and the Continental Shelf of North-West Europe, 1, A. W. Woodland, ed., Appl. Sci. Publ., London, 379-387.

Hughes, R. E., DeMaris, P. J., White, W. A., \& Cowin, D. K. 1987: Origin of clay minerals in Pennsylvanian strata of the Illinois Basin. In: Proc. Int. Clay Conf., Denver, 1985, L. G. Schultz, H. van Olphen, \& F. A. Mumpton, eds., Clay Miner. Soc., Indiana, 97-104.

Hurst, A. 1982: The clay mineralogy of Jurassic shales from Brora, NE Scotland. In: Proc. Int. Clay Conf. Bologna and Pavia, Italy, 1981, H. van Olphen \& F. Veniale, eds., Elsevier, Amsterdam, 677-684.

Hurst, A. 1985a: Diagenetic chlorite formation in some Mesozoic shales from the Sleipner area of the North Sea. Clay Miner., 20, 69-80.

Hurst, A. 1985b: The implications of clay mineralogy to palaeoclimate and provenance during the Jurassic in NE Scotland. Scott. J. Geol., 21, 143-160.

Inoue, A. \& Utada, M. 1983: Further investigations of a conversion series of dioctahedral mica/smectites in the Shinzan hydrothermal alter- 
ation area, Northeast Japan. Clays \& Clay Miner., 31, 401-412.

Inoue, A., Watanabe, T., Kohyama, N. \& Brusewitz, A. M. 1990: Characterization of illitization of smectite in bentonite beds at Kinnekulle, Sweden. Clays \& Clay Miner., 38, 241249.

Ireland, B. J., Curtis, C. D. \& Whiteman, J. A. 1983: Compositional variation within some glauconites and illites and implications for their stability and origins. Sedimentology, 30, 769-786.

Jakobsen, H. J., Jacobsen, H. \& Lindgreen, H. 1988: Solid state ${ }^{27} \mathrm{AI}$ and ${ }^{29} \mathrm{Si}$ MAS n.m.r. studies on diagenesis of mixed layer silicates in oil source rocks. Fuel, 67, 727-730.

Jeans, C. V., Merriman, R. J., Mitchell, J. G. \& Bland, D. J. 1982: Volcanic clays in the Cretaceous of Southern England and Northern Ireland. Clay Miner., 17, 105-156.

Jensen, P. K. 1982: Formation temperatures in the Danish Central Graben. Geol. Surv. Denmark, Yearbook, 91-106.

Jensen, T. F., Holm, L., Frandsen, N. \& Michelsen, O. 1986: Jurassic-Lower Cretaceous lithostratigraphic nomenclature for the Danish Central Trough. Geol. Surv. Denmark, Ser. A, 12, 65 pp.

Jones, T. G., Hughes, T. L., \& Tomkins, P. 1989: The ion content and mineralogy of a North Sea Cretaceous shale formation. Clay Miner., 24, 393-410.

Klimentidis, R. E. and MacKinnon, I. D. R. 1986: High resolution imaging of ordered mixedlayer clays. Clays \& Clay Miner., 34, 155-164.

Knox, R. W. O'B. \& Fletcher, B. N. 1978: Bentonites in the lower D beds (Ryazanian) of the Speeton Clay of Yorkshire. Proc. Yorkshire Geol. Soc., 42, 21-27.

Lahann, R. W. \& Roberson, H. E. 1980: Dissolution of silica from montmorillonite: effect of solution chemistry. Geochim. Cosmochim. Acta, 44, 1937-1943.

Lai, T. M. \& Mortland, M. M. 1960: Selfdiffusion of exchangeable cations in bentonite. In: Clays and Clay Miner., Proc. 9th Natl. Conf., West Lafayette, Indiana, 1960, A. Swineford, ed., Pergamon Press, New York, 229-247.

Larsen, G. 1966: Rhaetic-Jurassic-Lower Cretaceous sediments in the Danish Embayment. (A heavy-mineral study.) Geol. Surv. Denmark, II. Series, No. 91, 127 pp.
Lindgreen, H. 1985: Diagenesis and primary migration in Upper Jurassic claystone source rocks in North Sea. Amer. Assoc. Pet. Geol. Bull., 69, 525-536.

Lindgreen, H. 1987a: Molecular sieving and primary migration in Upper Jurassic and Cambrian claystone source rocks. In: Petroleum Geology of North West Europe, 1, J. Brooks \& K. W. Glennie, eds., Graham and Trotman, London, 357-364.

Lindgreen, H. 1987b: Experiments on adsorption and molecular sieving and inferences on primary migration in Upper Jurassic claystone source rocks, North Sea. Amer. Assoc. Pet. Geol. Bull., 71, 308-321.

Lindgreen, H. 1988: Diagenesis and primary migration in Upper Jurassic claystone source rocks in North Sea: Reply. Amer. Assoc. Pet. Geol. Bull., 72, 1426-27.

Lindgreen, H. \& Hansen, P. L. 1991: Ordering of illite smectite in Upper Jurassic claystones from the North Sea. Clay Miner., 26, 105-125.

Lindgreen, H., Jacobsen, H., \& Jakobsen, H. J. 1991: Diagenetic structural transformations in North Sea Jurassic illite/smectite. Clays \& Clay Miner., 39, 54-69.

Lindgreen, H. \& Rasmussen, K. 1978: A microcrystalline Danish soil clay investigated by diffraction, spectroscopic, thermal, chemical dissolution and adsorption methods. Royal Vet. and Agric. Univ. Yearbook 1978, 103-137.

Long, G. \& Neglia, S. 1968: Composition de l'eau interstitielle des argiles et diagenèse des minéraux argileux. Rev. Inst. Francais Pétrole, 23, 53-70.

MacEwan, D. M. C. 1956: Fourier transform methods for studying scattering from lamellar systems. I. A direct method for analyzing interstratified mixtures. Kolloidzeitschrift, 149, 96108.

MacEwan, D. M. C. 1958: Fourier transform methods for studying $\mathrm{X}$-ray scattering from lamellar systems. II. The calculation of X-ray diffraction effects for various types of interstratification. Kolloidzeitschrift, 156, 61-67.

MacEwan, D. M. C. \& Amil, A. R. 1959: Fourier transform methods for studying $\mathrm{X}$-ray scattering from lamellar systems. III. Some calculated diffraction effects of practical importance in clay mineral studies. Kolloid Zeitschrift, 162, 93100. 
MacEwan, D. M. C. \& Wilson, M. J. 1984: Interlayer and intercalation complexes of clay minerals. In: Crystal Structures of Clay Minerals and their $X$ ray identification. G. W. Brindley \& G. Brown, eds., Mineral. Soc., London, 197248.

Maxwell, D. T. \& Hower, J. 1967: High-grade diagenesis and low-grade metamorphism of illite in the Precambrian Belt series. Amer. Mineral., 52, 843-857.

Mehra, O. P. \& Jackson, M. L. 1960: Iron oxide removal from soils and clays by a dithionite-citrate system buffered with sodium bicarbonate. In: Clays and Clay Miner., Proc. 7th Natl. Conf., Washington, D.C., 1958, A. Swineford, ed., Pergamon Press, New York, 317-327.

Mering, J. \& Oberlin, A. 1971: The smectites. In: The Electron-Optical Investigation of Clays, $\mathrm{J}$. A. Gard, ed., Mineral. Soc., London, 231-254.

Meunier, A. \& Velde, B. 1989: Solid solutions in I/S mixed layer minerals and illite. Amer. Mineral., 74, 1106-1112.

Michelsen, O. 1978: Stratigraphy and distribution of Jurassic deposits of the Norwegian-Danish Basin. Geol. Surv. Denmark, Ser. B, 8, 28 pp.

Michelsen, O. \& Andersen, C. 1983: Mesozoic structural and sedimentary development of the Danish Central Graben. Geol. Mijnbouw, 62, 93-102.

Michelsen, O., Frandsen, N., Holm, L., Jensen, T. F., Møller, J. J., \& Vejbæk, O. V. 1986: Jurassic Lower Cretaceous of the Danish Central Trough; depositional environments, tectonism, and reservoirs. Geol. Surv. Denmark. Ser. A, No. $16,45 \mathrm{pp}$.

Millot, G. 1970: Geology of Clays. Springer Verlag, London, 429 pp.

Milne, I. H. \& Earley, J. W. 1958: Effect of source and environment on clay minerals. Amer. Assoc. Pet. Geol. Bull., 42, 328-338.

Morgan, D. J. 1977: Simultaneous DTA- EGA of minerals and natural mineral mixtures. $J$. Thermal Analysis, 12, 245-263.

Myhre, L. (ed.) 1977: Lithology wells 2/8-1 and 2/11-1. NPD Paper, No.7, Oljedirektoratet, Stavanger, $24 \mathrm{pp}$.

Nadeau, P. H. 1985: The physical dimensions of fundamental clay particles. Clay Miner., 20, 499-514.

Nadeau, P. H. \& Bain, D. C. 1986: Composition of some smectites and diagenetic illitic clays and implications for their origin. Clays \& Clay Miner., 34, 455-464.

Nadeau, P. H. \& Reynolds, R. C. 1981a: Burial and contact metamorphism in the Mancos Shale. Clays \& Clay Miner., 29, 249-259.

Nadeau, P. H. \& Reynolds, R. C. 1981b: Volcanic components in pelitic sediments. Nature, 294, 72-74.

Nadeau, P. H., Tait, M. J., McHardy, W. J., \& Wilson, M. J. 1984: Interstratified XRD characteristics of physical mixtures of elementary clay particles. Clay Miner., 19, 67-76.

Nadeau, P. H., Wilson, M. J.,McHardy, W. J., \& Tait, J. M. 1985: The conversion of smectite to illite during diagenesis: evidence from some illitic clays from bentonites and sandstones. Mineral. Mag., 49, 393-400.

Nielsen, O. B., Sørensen, S., Thiede, J. \& Skarbø, O. 1986: Cenozoic differential subsidence of North Sea. Amer. Assoc. Pet. Geol. Bull., 70, 276-298.

Odom, J. W. \& Low, P. F. 1978: Relation between swelling, surface area and $b$-dimension of Na- montmorillonites. Clays \& Clay Miner., $26,345-351$.

Ofstad, K. 1981: The Eldfisk area. NPD Paper, No. 30, Oljedirektoratet, Stavanger, $36 \mathrm{pp}$.

van Olphen, H. 1963: Compaction of clay sediments in the range of molecular particle distances. In: Clays and Clay Miner., Proc. 11th Natl. Conf., Ottawa, Ontario, 1962, W. F.Bradley, ed., Pergamon Press, New York, 178-187.

van Olphen, H. 1966: Collapse of potassium montmorillonite clays upon heating- "potassium fixation". In: Clays and Clay Miner., Proc. 14th Natl. Conf., Berkeley, California, S. W. Bailey, ed., Pergamon Press, New York, 393-405.

Parham, W. E. 1966: Lateral variations of clay mineral assemblages in modern and ancient sediments. In: Proc. Int. Clay Conf., 1966, Jerusalem, L. Heller \& A. Weiss, eds., Israel Prog. Sci. Translations, Jerusalem, 1, 135-145.

Pearson, M. J. \& Small, J. S. 1988: Illite-smectite diagenesis and paleotemperatures in northern North Sea Quarternary to Mesozoic shale sequences. Clay Miner., 23, 109-132.

Pearson, M. J., Watkins, D. \& Small, J. S. 1982: Clay diagenesis and organic maturation in northern North Sea sediments. In: Proc. Int. Clay Conf., Bologna, Pavia, 1981, H. van Ol- 
phen \& F. Veniale, eds., Dev. Sedimentology 35, Elsevier, Amsterdam, 665-675.

Perry, E. \& Hower, J. 1970: Burial diagenesis in Gulf Coast pelitic sediments. Clays \& Clay Miner., 18, 165-177.

Perry, E. A. \& Hower, J. 1972: Late-stage dehydration in deeply buried pelitic sediments. Amer. Assoc. Pet. Geol. Bull., 56, 2013-2021.

Petukhov, A. V., Zvereva, O. V. \& Tikhomirova, Y. S. 1981: Montmorillonitization of clay upon interaction with hydrocarbons. Doklady Akad. Sci. USSR, Earth Sci. Section, 258, 196199.

Pollard, C. O. (Jr.) 1971: Appendix: Semidisplacive mechanism for diagenetic alteration of montmorillonite layers to illite layers. Geol. Soc. Amer. Spec. Paper, 134, 79-96.

Porrenga, D. H. 1965: Clay minerals in recent sediments of the Niger Delta. In: Clays and Clay Miner., Proc. 14th Natl. Conf., Berkeley, California, S. W. Bailey, ed., Pergamon Press, New York, 221-233.

Powell, T. G., Foscolos, A. E., Gunther, P. R., \& Snowdon, L. R. 1978: Diagenesis of organic matter and fine clay minerals: a comparative study. Geochim. Cosmochim. Acta, 42, 11811197.

Powers, M. C. 1959: Adjustment of clays to chemical change and the concept of the equivalence level. In: Clays and Clay Miner., Proc. 6th Natl. Conf., Berkeley, California, 1957, A. Swineford, ed., Pergamon Press, New York, 309326.

Powers, M. C. 1967: Fluid-release mechanisms in compacting marine mudrocks and their importance in oil exploration. Amer. Assoc. Pet. Bull., $51,1240-1254$.

Primmer, T. J. \& Shaw, H. F. 1987: Diagenesis in shales: evidence from backscattered electron microscopy and electron microprobe analysis. In: Proc. Int. Clay Conf., Denver, 1985, L. G. Schultz, H. van Olphen, \& F. A. Mumpton, eds., Clay Miner. Soc., Bloomington, Indiana, 135143.

Ramseyer, K. \& Boles, J. R. 1986: Mixedlayer illite/smectite minerals in Tertiary sandstones and shales, San Joaquin Basin, California. Clays \& Clay Miner., 34, 115-124.

Ravina, I. \& Low, P. F. 1972: Relation between swelling, water properties and $b$-dimen- sion in montmorillonite-water systems. Clays \& Clay Miner., 20, 109-123.

Ravina, I. \& Low, P. F. 1977: Change of $b$ dimension with swelling of montmorillonite. Clays \& Clay Miner., 25, 201-204.

Rawson, P. F. \& Riley, L. A. 1982: Latest Jurassic- Early Cretaceous events and the "Late Cimmerian Unconformity" in the North Sea area. Amer. Assoc. Pet. Geol. Bull., 66, 2628-2648.

Reynolds, R. C. 1984: Interstratified clay minerals. In: Crystal Structures of Clay Minerals and their X-ray Identification. G. W. Brindley \& G. Brown, eds., Mineral. Soc., London, 249-304.

Reynolds, R. C. \& Hower, J. 1970: The nature of interlayering in mixed-layer illite-montmorillonites. Clays \& Clay Miner., 18, 25-36.

Roberson, H. E. \& Lahann, R. W. 1981: Smectite to illite conversion rates: effects of solution chemistry. Clays \& Clay Miner., 29, 129-135.

Ross, C. S. \& Hendricks, S. B. 1945: Minerals of the montmorillonite group. U.S. Geol. Surv., Prof. Pap., 205-B, 23-79.

Ross, G. J. \& Rich, C. I. 1973: Changes in $b-$ dimension in relation to potassium exchange and to oxidation of phlogopite and biotite. Clays \& Clay Miner., 21, 201-204.

Russell, J. D. 1988: Infrared methods. In: Handbook of Determinative Methods in Clay Mineralogy, M. J. Wilson, ed., Blackie, London, 133-173.

Sawhney, B. L. 1967: Interstratification in vermiculite. In: Clays and Clay Miner., Proc. 15th Natl. Conf., Pittsburgh, Pennsylvania, 1966, S. W. Bailey, ed., Pergamon Press, New York, $75-84$.

Sayin, M. \& von Reichenbach, H. G. 1978: Infrared spectra of muscovites as affected by chemical composition, heating and particle size. Clay Miner., 13, 241-254.

Schmidt, B. J. 1985: A coal petrographic source rock evaluation of the Rhaetic-JurassicLower Cretaceous sediments of the Børglum 1 and Uglev 1 wells, Denmark. Bull. Geol. Soc. Denmark, 33, 239-252.

Schmidt, G. W. 1973: Interstitial water composition and geochemistry of deep Gulf Coast shales and sands. Amer. Assoc. Pet. Geol. Bull., 57, 321-337

Scotchman, I. C. 1988: Diagenesis and primary migration in Upper Jurassic claystone source 
rocks in North Sea: Discussion. Amer. Assoc. Pet. Geol. Bull., 72, 1423-25.

Sellwood, B. W. 1972: Regional environment changes across a Lower Jurassic stage-boundary in Britain. Palaeont. 15, 125-157.

Sellwood, B. W. \& Sladen, C. P. 1981: Mesozoic and Tertiary argillaceous units: distribution and composition. Q.J. Eng. Geol. London, 14, 263-275.

Smart, G. \& Clayton, T. 1985: The progressive illitization of interstratified illite-smectite from Carboniferous sediments of northern England and its relationship to organic maturity indicators. Clay Miner., 20, 455-466.

Środoń, J. 1979: Correlation between coal and clay diagenesis in the Carboniferous of the Upper Silesian Coal Basin. In: Proc. Int. Clay Conf., Oxford, 1978, M. M. Mortland \& V. C. Farmer, eds., Dev. Sedimentology, 27, 251-260.

Srodoń, J. 1984: Mixed-layer illite-smectite in low temperature diagenesis: data from the Miocene of the Carpathian Foredeep. Clay Miner., 19, 205-215.

Środoń, J. \& Eberl, D. D. 1984: Illite. In: Micas, S. W. Bailey, ed., Rev. Mineralogy, 13, Min. Soc. Amer., Blacksburg, Virginia, 495-544.

Srodoń, J., Morgan, D. J., Eslinger, E. V., Eberl, D., \& Karlinger, M. R. 1986: Chemistry of illite/smectite and end-member illite. Clays \& Clay Miner., 34, 369-378.

Sterne, E. J., Reynolds, R. C., \& Zantop, H. 1982: Natural ammonium illites from black shales hosting a stratiform base metal deposit, Delong Mountains, Northern Alaska. Clays \& Clay Miner., 30, 161-166.

Stucki, J. W., Low, P. F., Roth, C. B., \& Golden, D. C. 1984: Effects of oxidation state of octahedral iron on clay swelling. Clays \& Clay Miner., 32, 357-362.

Thomsen, E. 1984: A coal petrographical investigation of the well 2/11-1. Geol. Survey Denmark. Internal Report No. 38, 28 pp.

Thomsen, E., Lindgreen, H., \& Wrang, P. 1983: Investigation on the source rock potential of Denmark. Geol. Mijnbouw, 62, 221-239.

Tyson, R. V., Wilson, R. C. L., \& Downie, C. 1979: A stratified water column environmental model for the type Kimmeridge Clay. Nature, 277, 377-380.

Veblen, D. R., Guthrie, G. D., Livi, K. J. T, \& Reynolds, R. C. 1990: High-resolution trans- mission electron microscopy and electron diffraction of mixed layer illite/smectite: Experimental results. Clays \& Clay Miner., 38, 1-13.

Vedder, W. 1965: Ammonium in muscovite. Geochim. Cosmochim. Acta, 29, 221-228.

Velde, B. 1985: Possible chemical controls of illite/smectite composition during diagenesis. Mineral. Mag., 49, 387-391.

Velde, B. \& Brusewitz, A. M. 1986: Compositional variation in component layers in natural illite/smectite. Clays \& Clay Miner., 34, 651-657.

Vollset, J. \& Doré, A. G. (eds.) 1984: A revised Triassic and Jurassic lithostratigraphic nomenclature for the Norwegian North Sea. NPDBulletin No. 3, Oljedirektoratet, Stavanger, 53 pp.

Weaver, C. E. 1958a: Geologic interpretation of argillaceous sediments. Part I. Origin and significance of clay minerals in sedimentary rocks. Amer. Assoc. Pet. Geol. Bull., 42, 254-271.

Weaver, C. E. 1958b: Geologic interpretation of argillaceous sediments. Part II. Clay petrology of Upper Mississippian-Lower Pennsylvanian sediments of Central United States. Amer. Assoc. Pet. Geol. Bull., 42, 272-309.

Weaver, C. E. 1959: The clay petrology of sediments. In: Clays and Clay Miner., Proc. 6th Natl. Conf., Berkeley, California, 1957, A. Swineford, ed., Pergamon Press, New York, 154187.

Weaver, C. E. 1960: Possible uses of clay minerals in search for oil. Amer. Assoc. Pet. Geol. Bull., 44, 1505-1518.

Weaver, C. E. 1988: Clays, Muds, and Shales. Dev. Sedimentology, 44, Elsevier, Amsterdam, 819 pp.

Weaver, C. E. \& Beck, K. C. 1971: Clay water diagenesis during burial: how mud becomes gneiss. Geol. Soc. Amer., Spec. Pap., 134, 1-78.

Weaver, C. E. \& Pollard, L. D. 1973: The Chemistry of Clay Minerals. Elsevier, Amsterdam, $250 \mathrm{pp}$.

Weir, A. H., Nixon, H. L., \& Woods, R. D. 1960: Measurement of thickness of dispersed clay flakes with the electron microscope. In: Clays and Clay Miner., Proc. 9th Natl. Conf., West Lafayette, Indiana, 1960, A. Swineford, ed., Pergamon Press, New York, 419-423.

Whitney, C. \& Northrop, H. R. 1988: Experimental investigation of the smectite to illite reac- 


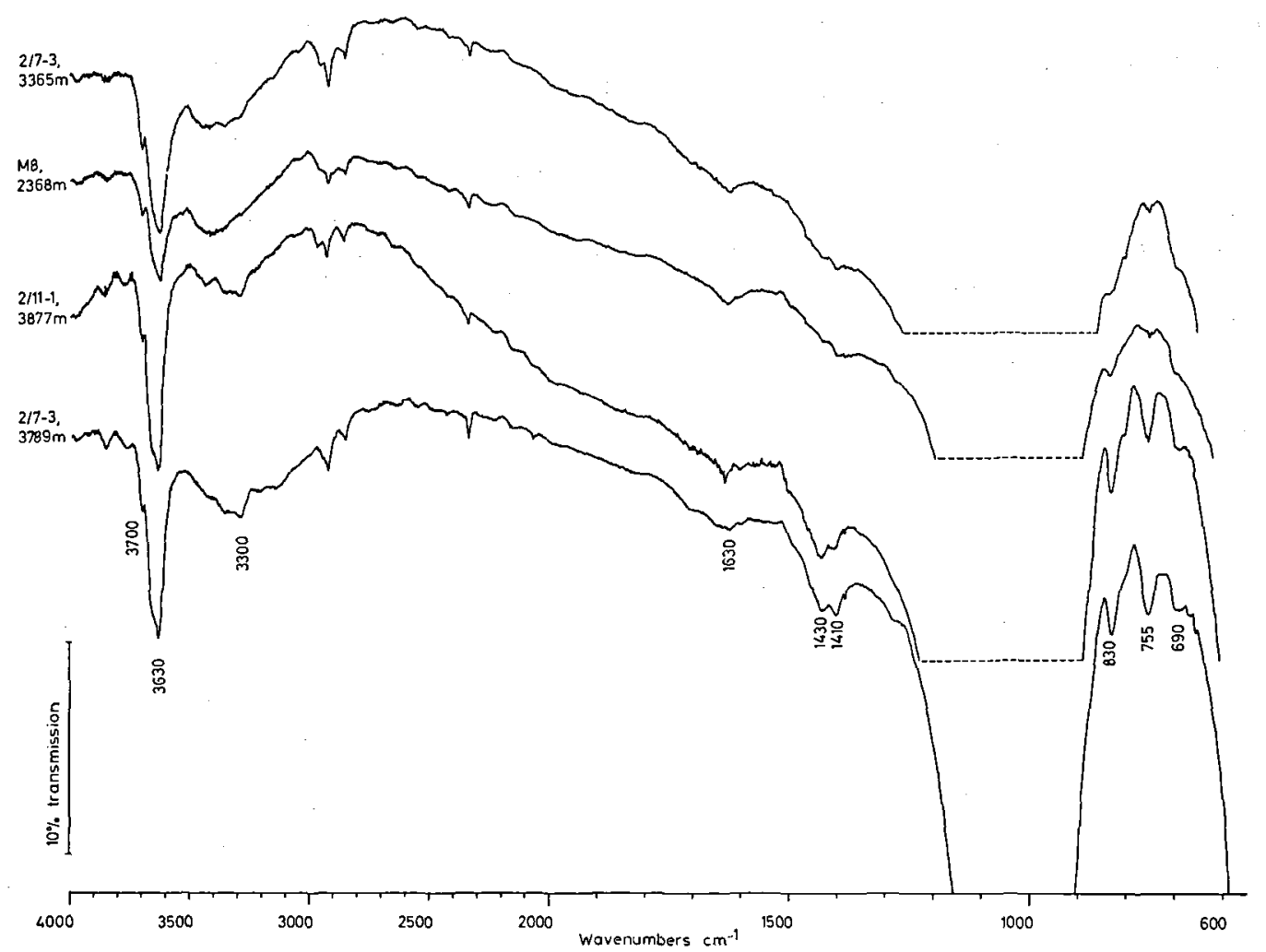

Fig. A1. Transmission FT-IR spectra of illite/smectite fractions. The section $4000 \mathrm{~cm}^{-1}$ to $600 \mathrm{~cm}^{-1} .3 \mathrm{mg}$ sample per $300 \mathrm{mg} \mathrm{KBr}$.

tion: dual reaction mechanisms and oxygen-isotope systematics. Amer. Mineral., 73, 77-90.

Wignall, P. B. 1989: Sedimentary dynamics of the Kimmeridge Clay: tempests and earthquakes. J. Geol. Soc. London, 146, 273-284.

Wignall, P. B. \& Ruffell, A. H. 1990: The influence of a sudden climatic change on marine deposition in the Kimmeridgian of northwest Europe. J. Geol. Soc., London, 147, 365-371.

Yeh, H.-W. \& Savin, S. M. 1977: Mechanism of burial metamorphism of argillaceous sediment, 3. Oxygen isotope evidence. Geol. Soc. Amer. Bull., 88, 1321-1330.

Ziegler, P. A. 1981: Evolution of sedimentary basins in North-West Europe. In: Petroleum Geology of the Continental Shelf of North-West Europe, L. V. Illing \& G. D. Hobson, eds., Inst. Petroleum, London, 3-39.

\section{Appendix}

Infrared spectroscopy

Infrared spectroscopy was made on a Bruker 113V FT IR spectrometer at Chemical Laboratory V, H.C.Ørsted Institute, University of Copenhagen, by Daniel Christensen. $\mathrm{KBr}$ pellets heated overnight at $150^{\circ} \mathrm{C}$ for dewatering were analysed.

IR spectra are shown in figs. A1-A3. The peaks at $1630 \mathrm{~cm}^{-1}$ and at about $3400 \mathrm{~cm}^{-1}$ are due to water left after heating at $150^{\circ} \mathrm{C}$. One, sharp band at $3700-3705 \mathrm{~cm}^{-1}$ is due to a small content of kaolinite (fig. A1). In illite/smectite, the strong hydroxyl band at $3630 \mathrm{~cm}^{-1}$, the $\mathrm{Al}-\mathrm{Mg}-\mathrm{OH}$ deformation band at $830 \mathrm{~cm}^{-1}$ and the Al-O-Si in plane vibration at $755 \mathrm{~cm}^{-1}$ are almost certainly diagnostic for illite (Russell 1988). A weaker band at $3650 \mathrm{~cm}^{-1}$ may be due to beidellite. However, beidellite bands at $818 \mathrm{~cm}^{-1}$ and $770 \mathrm{~cm}^{-1}$ (Russell 1988) are not seen in any sample. The band at $910-930 \mathrm{~cm}^{-1}$ (fig. A2) is due to Al- 


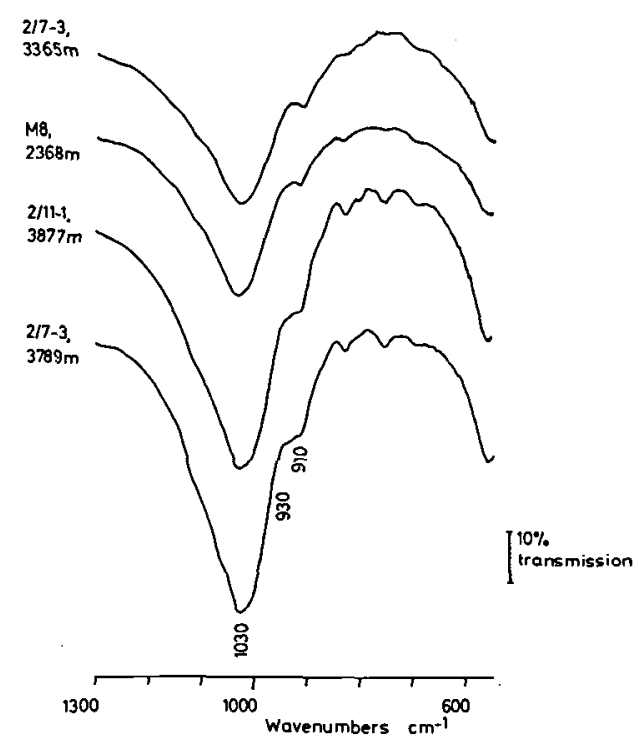

Fig. A2. Transmission FT-IR spectra of illite/smectite fractions. The section $1300 \mathrm{~cm}^{-1}$ to $600 \mathrm{~cm}^{-1}$ with smaller amounts of sample in pellets $(0.3 \mathrm{mg} / 300 \mathrm{mg} \mathrm{KBr})$.

Al-OH deformation. It broadens to $910-930 \mathrm{~cm}^{-1}$ with increasing amount of illite layers in illite/ smectite. This is probably due to an increasing amount of layers with a lower amount of octahedral $\mathrm{Mg}$ and $\mathrm{Fe}$, as muscovites show a shift of this absorption band from $930 \mathrm{~cm}^{-1}$ to $908 \mathrm{~cm}^{-1}$ with increasing amount of $\mathrm{Fe}$ and $\mathrm{Mg}$ in the octahedral sheet (Sayin \& Reichenbach 1978). The strong band at $1030 \mathrm{~cm}^{-1}$ is due to $\mathrm{Si}-\mathrm{O}$ stretching (Farmer \& Russell 1964). It is not split into two bands as in rectorite (Farmer 1974). The bands at $1410 \mathrm{~cm}^{-1}, 1430 \mathrm{~cm}^{-1}$ and $3360 \mathrm{~cm}^{-1}$ are due to interlayer $\mathrm{NH}_{4}^{+}$(Vedder 1965; Chourabi \& Fripiat 1981; Sterne et al. 1982).

The strong absorption bands in the region below $550 \mathrm{~cm}^{-1}$ have been assigned to in-plane vibration of the octahedral ions and their adjacent oxygen planes and to $\mathrm{Si}-\mathrm{O}$ bending, and substitution of $\mathrm{Al}^{3+}$ for $\mathrm{Si}^{4+}$ does not greatly shift the

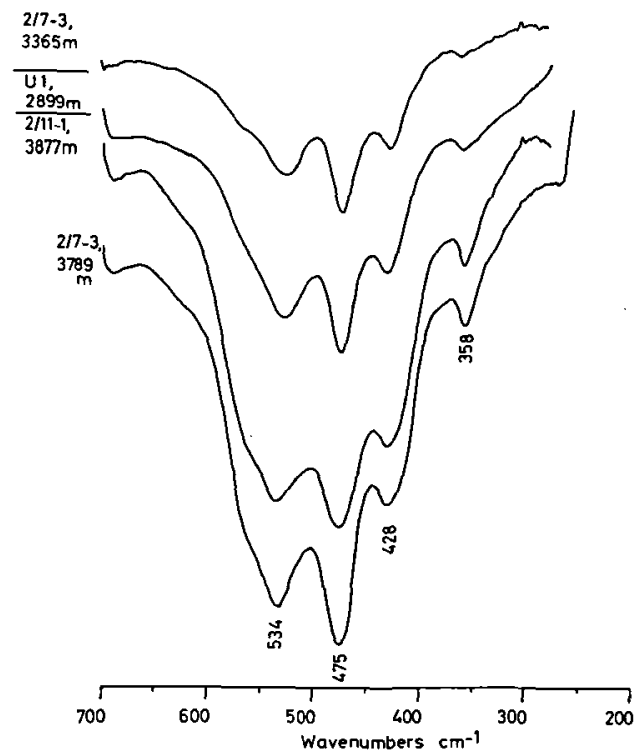

Fig. A3. Transmission FT-IR spectra of illite/smectite fractions. The section $700 \mathrm{~cm}^{-1}$ to $200 \mathrm{~cm}^{-1}$ with $3 \mathrm{mg}$ sample per $300 \mathrm{mg}$ $\mathrm{KBr}$.

main absorption bands in this region (Farmer \& Russell 1964). Farmer \& Russell concluded that the pattern in this region is largely determined by the nature and the distribution of the octahedral cations. The absorption patterns for the investigated illite/smectites appear similar to each other in this region (fig. A3) with absorption bands at $570 \mathrm{~cm}^{-1}$ (weak), $534 \mathrm{~cm}^{-1}, 475 \mathrm{~cm}^{-1}, 428 \mathrm{~cm}^{-1}$, and $358 \mathrm{~cm}^{-1}$ (weak). This indicates that the octahedral sheet is little changed during diagenetic illite layer formation in illite/smectite, in contrast to the indications of the $910-930 \mathrm{~cm}^{-1}$ peak. With increasing amount of illite layers in illite/smectite, the main change of the infrared spectra (fig. A1) is an increase in intensity of the illite bands at $3630 \mathrm{~cm}^{-1}, 830 \mathrm{~cm}^{-1}$ and $755 \mathrm{~cm}^{-1}$. The ammonium bands also increase in intensity with increasing amount of illite layers in illite/smectite. 